МИНИСТЕРСТВО НАУКИ И ВЫСШЕГО ОБРАЗОВАНИЯ РОССИЙСКОЙ ФЕДЕРАЦИИ ФЕДЕРАЛЬНОЕ ГОСУДАРСТВЕННОЕ БЮДЖЕТНОЕ УЧРЕЖДЕНИЕ НАУКИ

ИНСТИТУТ МОРСКОЙ ГЕОЛОГИИ И ГЕОФИЗИКИ

ДАЛЬНЕВОСТОЧНОГО ОТДЕЛЕНИЯ РОССИЙСКОЙ АКАДЕМИИ НАУК

САХАЛИНСКИЙ ФИЛИАЛ

ФЕДЕРАЛЬНОГО ГОСУДАРСТВЕННОГО УЧРЕЖДЕНИЯ НАУКИ

ФЕДЕРАЛЬНОГО ИССЛЕДОВАТЕЛЬСКОГО ЦЕНТРА

ЕДИНОЙ ГЕОФИЗИЧЕСКОЙ СЛУЖБЫ

РОССИЙСКОЙ АКАДЕМИИ НАУК

THE MINISTRY OF EDUCATION AND SCIENCE OF THE RUSSIAN FEDERATION INSTITUTE OF MARINE GEOLOGY AND GEOPHYSICS

FAR EASTERN BRANCH OF THE RUSSIAN ACADEMY OF SCIENCES

FEDERAL RESEARCH CENTER

GEOPHYSICAL SURVEY

OF RUSSIAN ACADEMY OF SCIENCES

SAKHALIN BRANCH 
D.A. Safonov, N.V. Nagornykh, N.S. Kovalenko

\section{SEISMICITY OF THE AMUR AND PRIMORYE REGION}

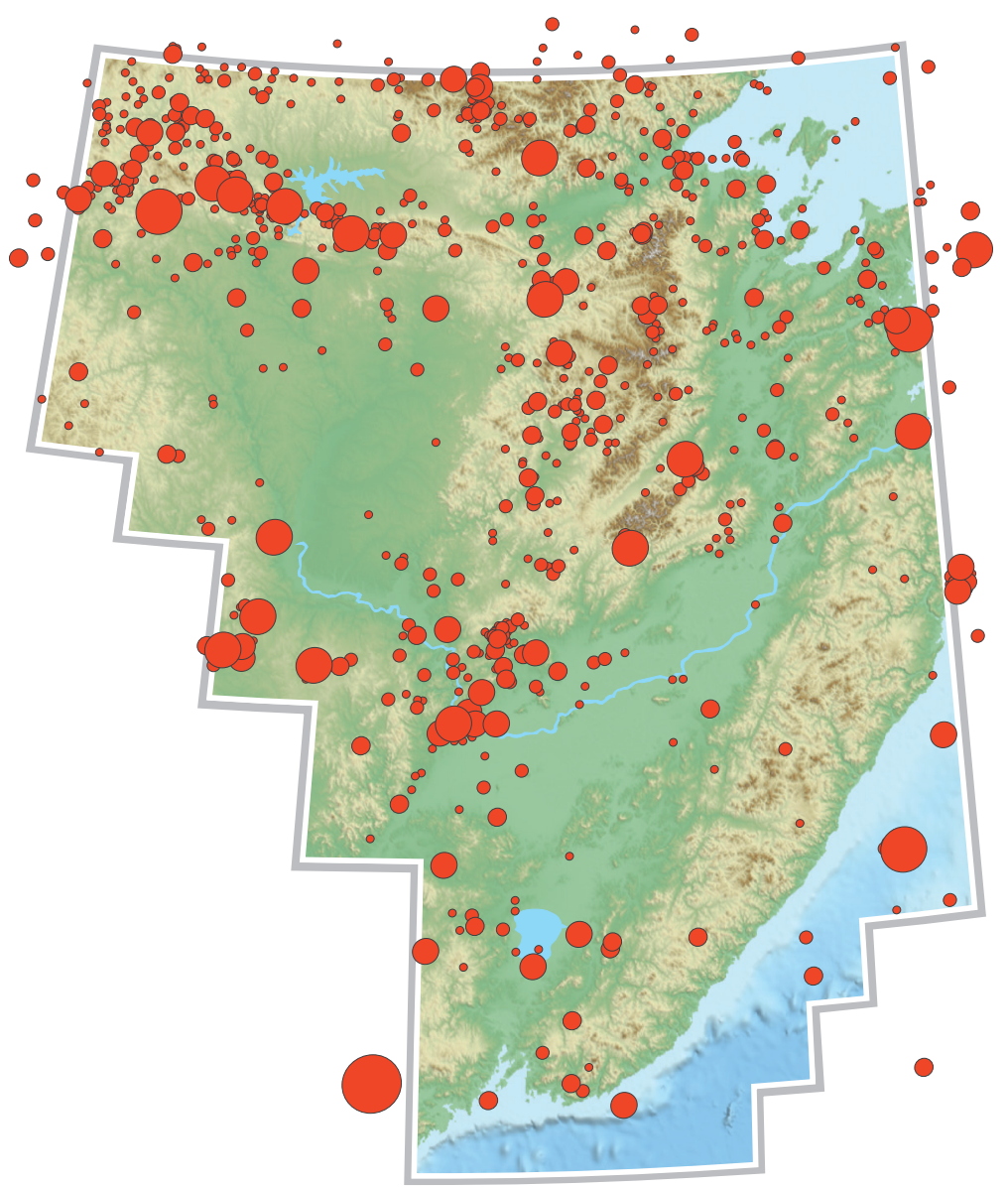

Yuzhno-Sakhalinsk

2019 
Д.А. Сафонов, Т.В. Нагорных, Н.С. Коваленко

\section{СЕЙСМИЧНОСТЬ РЕГИОНА ПРИАМУРЬЕ И ПРИМОРЬЕ}

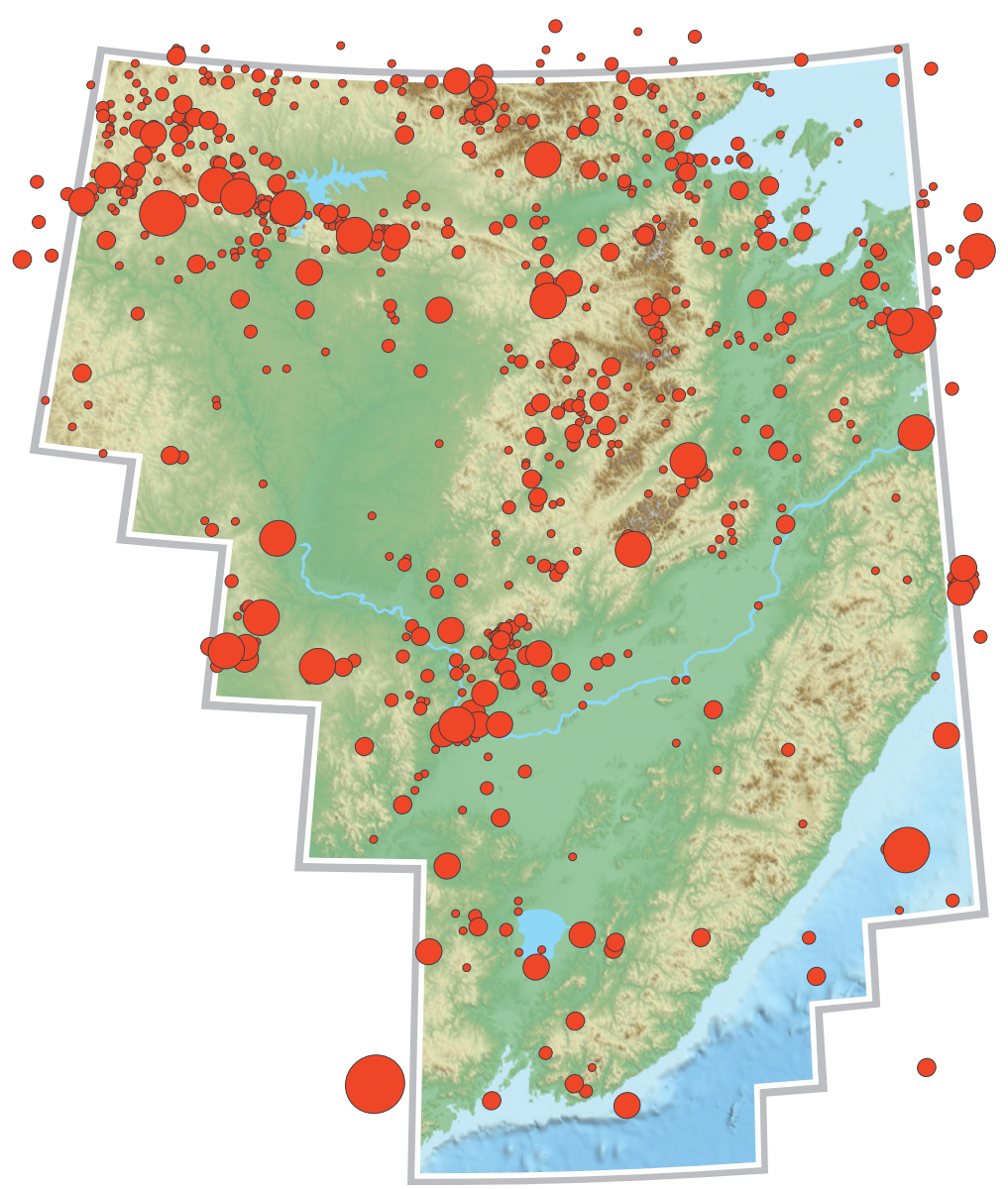

Южно-Сахалинск

2019 
УДК 550.34

С 217

Сафонов Д.А., Нагорных Т.В., Коваленко Н.С. Сейсмичность региона Приамурье и Приморье / ред. канд. физ.-мат. наук А.С. Прытков.- Южно-Сахалинск: ИМГиГ ДВО РАН, 2019. - 104 с. + 1 электрон. опт. диск (CD).

ISBN 978-5-6040621-0-4

DOI: $10.30730 / 978-5-6040621-0-4.2019-1$

В работе представлена информация о сейсмичности региона Приамурье и Приморье. Приведен каталог основных и дополнительных параметров землетрясений с 1865 по 2015 год, а также сведения, которые могут помочь в интерпретации данных каталога. Показано положение региона с сейсмологической позиции в тектонических структурах Дальнего Востока. Представлены комплексные фактические данные по всем крупным землетрясениям региона. Проведен анализ коровой и мантийной сейсмичности. На основе известных механизмов очагов землетрясений получены оценки поля тектонических напряжений в коре и верхней мантии региона.

Работа представляет интерес для широкого круга специалистов в области сейсмологии, сейсмотектоники, геологии и геодинамики Дальнего Востока России, а также всех, кто интересуется историей развития науки в этом регионе.

Полная версия каталога представлена на CD.

Ключевые слова: Приамурье, Приморье, землетрясение, сейсмичность, сейсмическая активность, каталог, сейсмотектоника, механизм очага.

Ответственный редактор: канд. физ.-мат. наук А.С. Прытков

Рецензент: канд. геол.-мин. наук Я.Б. Радзиминович

Печатается по решению Ученого совета

Федерального государственного бюджетного учреждения науки

Института морской геологии и геофизики Дальневосточного отделения Российской академии наук. Россия, 693022, г. Южно-Сахалинск, ул. Науки, д. 1Б; e-mail: nauka@imgg.ru

(C) Сафонов Д.А., Нагорных Т.В., Коваленко Н.С., 2019

(С) ИМГИГ ДВО РАН, 2019

(C) СФ ФИЦ ЕГС РАН, 2019

UDC 550.34

$\mathrm{S} 217$

Safonov D.A., Nagornykh T.V., Kovalenko N.S. Seismicity of the Amur and Primorye region / Edit by

A.S. Prytkov. - Yuzhno-Sakhalinsk: IMGG FEB RAS, 2019. - 104 p. + 1 electron. opt. disk (CD).

ISBN 978-5-6040621-0-4

DOI: $10.30730 / 978-5-6040621-0-4.2019-1$

The published work presents information on the seismicity of the Amur and Primorye region. The catalog of basic and additional parameters of earthquakes is given from 1865 to 2015 , as well as information that can help in the interpretation of catalog data. The position of the region from the seismological point of view in the tectonic structures of the Far East is shown. Comprehensive factual data are presented for all major earthquakes in the region. The analysis of the crust and mantle seismicity is carried out. The seismicity of the earth's crust and mantle is analyzed. On the basis of known earthquake focal mechanisms received a field of tectonic stress in the crust and upper mantle.

The work will be of interest to a wide range of specialists in seismology, seismotectonics, geology and geodynamics of the Far East of Russia, as well as all those who are interested in the history of science in this region.

The full version of the catalogue is available on CD.

Key words: Amur, Primorye, earthquake, seismicity, seismic activity, catalog, seismotectonics, focal mechanism.

Executive editor: cand. phys.-math. sciences A.S. Prytkov

Reviewer: cand. geol.-miner. sciences Ya.B. Radziminovich

The book is published according to decision of the

Scientific Council of the Institute of Marine Geology \& Geophysics

Far Eastern Branch of the Russion Academy of Sciences.

Russia, 693022, Yuzhno-Sakhalinsk, Nauki str. 1 B; e-mail: nauka@imgg.ru

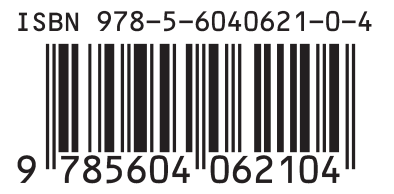

(C) Safonov D.A., Nagornykh T.V., Kovalenko N.S., 2019

(C) IMGG FEB RAS, 2019

(C) SF FRC GS RAS, 2019 


\section{СОДЕРЖАНИЕ}

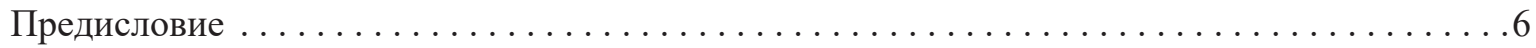

Введение . . . . . . . . . . . . . . . . . . . . . . . . . . . . . . . . . . . .7

Глава 1. Развитие региональной сети сейсмологических наблюдений. . . . . . . . . . .9

Глава 2. Представительность каталога землетрясений. . . . . . . . . . . . . 13

Глава 3. Структура каталогов землетрясений и очистка от взрывов. . . . . . . . . . . . . . 19

Глава 4. Разломная тектоника и сейсмогенные зоны Приамурья и Приморья . . . . . . . 23

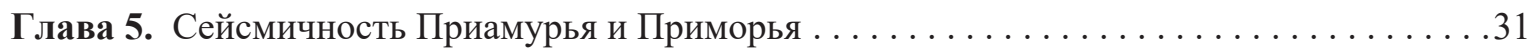

5.1 Глубокофокусные землетрясения . . . . . . . . . . . . . . . . . . . .

5.2 Коровые землетрясения. Общая характеристика . . . . . . . . . . . . . . 32

5.3 Становой район (№ 1) . . . . . . . . . . . . . . . . . . . . . . . . 37

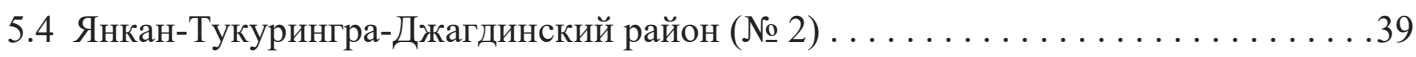

5.5 Зейско-Селемджинский район (№ 3) . . . . . . . . . . . . . . . . . . . . . .42

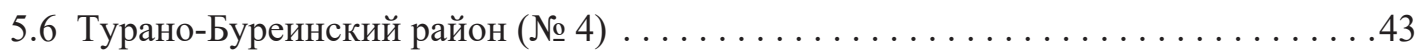

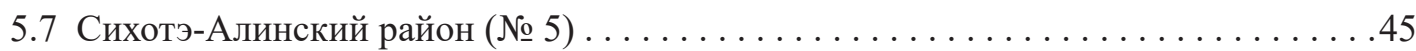

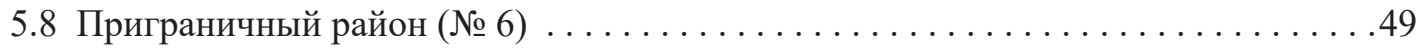

Глава 6. Реконструкция тектонических напряжений в коре и мантии региона . . . . . . . .51

Заключение . . . . . . . . . . . . . . . . . . . . . . . . . . . . . . . . . . . . . . . . . 61

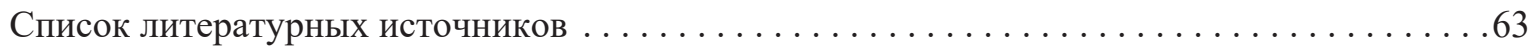

Приложение 1А. Каталог землетрясений региона Приамурье и Приморье 1865-2015 гг.

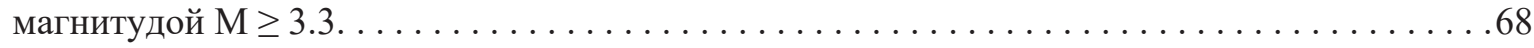

Приложение 2. Каталог механизмов очагов землетрясений региона

Приамурье и Приморье $1964-2014$ гг. . . . . . . . . . . . . . . . . . . . . . . 93

\section{Ha CD:}

Приложение 1. Каталог землетрясений региона Приамурье и Приморье 1865-2015 гг.

Приложение 2. Каталог механизмов очагов землетрясений региона Приамурье и Приморье 1964-2014 гг. 


\section{ПРЕДИСЛОВИЕ}

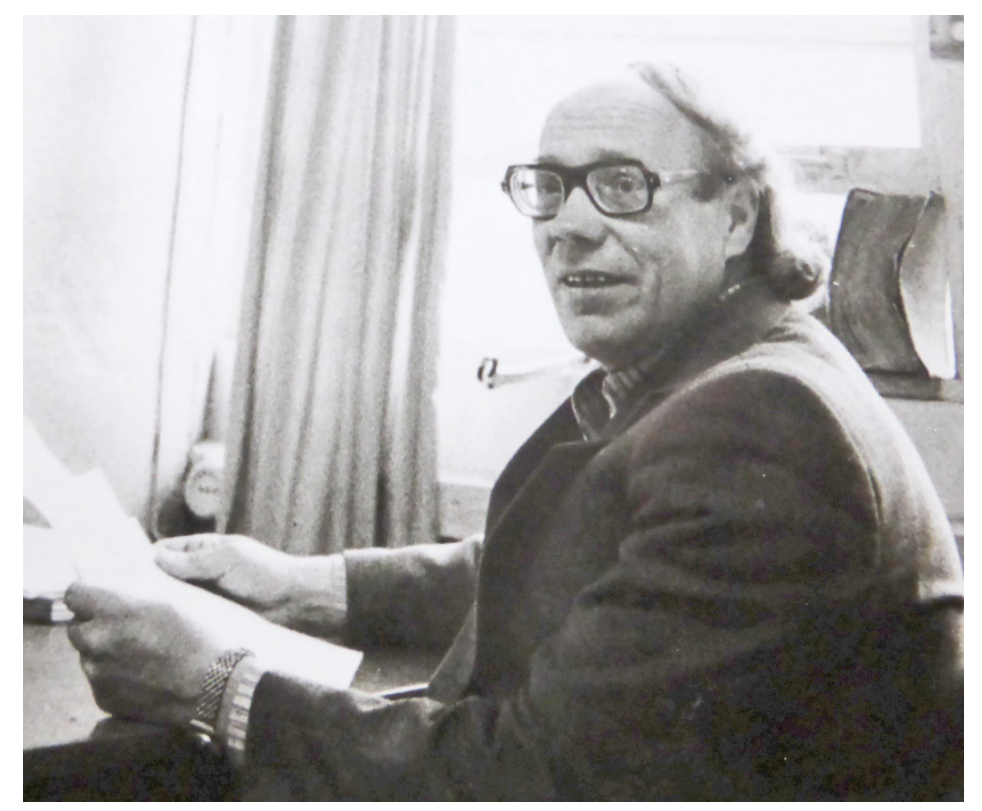

Данная работа посвящена нашему учителю-наставнику Леониду Семеновичу Оскорбину (1934-2006), который был одним из создателей системы сейсмологических наблюдений не только в Приамурье и Приморье, но и на Курильских островах и о. Сахалин. Один из ведущих сейсмологов Сахалинского комплексного научноисследовательского института (СахКНИИ) ДВНЦ АН СССР (в настоящее время Институт морской геологии и геофизики ДВО РАН, Южно-
Сахалинск), он активно участвовал в организации и развитии сети сейсмических станций, в совершенствовании методики сейсмологических наблюдений, составлении сейсмологических каталогов, изучении их представительности, повторяемости землетрясений, обосновании зон ВОЗ, а также в работах по сейсмическому районированию Дальнего Востока. При его участии опубликовано более двух сотен научных работ.

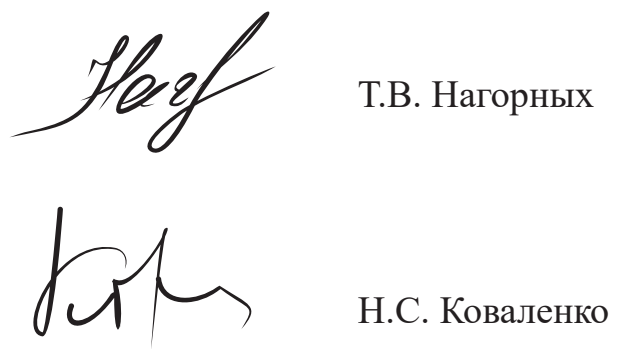




\section{ВВЕДЕНИЕ}

Приамурье и Приморье относятся к числу сейсмоактивных областей России с умеренной сейсмичностью. Данный регион площадью при-

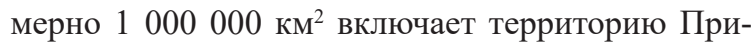
морского края, Амурской области, Еврейской автономной области, Хабаровского края до $56^{\circ}$ с. ш. и приграничную территорию Китая.

Первые сведения о землетрясениях в Приморской и Амурской областях содержатся в каталоге И.В. Мушкетова и А.П. Орлова [Мушкетов, Орлов, 1893]. Ранние сведения о землетрясениях Забайкалья, Приамурья, Приморья с 1700 по 1936 г. можно почерпнуть из публикаций А.С. Уланова [Уланов, 1932] и В.В. Попова [Попов, 1939].

Сейсмичность, геология, сейсмотектоника Приамурья, особенно района прохождения Байкало-Амурской железнодорожной магистрали, были детально изучены в 1960-80 годы [Красный, 1963; Николаев и др., 1979, 1982, 1989; Бельтенев, 1982; Солоненко и др., 1985; и др.]. Остальная часть Приамурья и особенно Приморье, где происходило много весьма заметных землетрясений, также не оставались без внимания [Даммер, 1971; Аргентов и др., 1976; Леонов и др., 1977; Салун, 1978; Органова, Кручинина, 1978; Бормотов, Войтенок, 1998; Mackey at al., 2003, 2012; Имаев и др., 2003; Степашко, 2011; Диденко и др., 2017; и др.].

В Институте морской геологии и геофизики ДВО РАН изучением региона Приамурье и Приморье руководил Л.С. Оскорбин. Леонид Семенович в целях изучения сейсмотектонического режима и сейсмического районирования Приамурья и Приморья начал составлять каталог землетрясений, провел детальный анализ сейсмического режима, макросейсмических проявлений, выполнил районирование территории по сейсмогенным зонам.

Данная работа во многом опирается на предложенную Л.С. Оскорбиным основу: границы территории, схему построения материала, собранные данные и публикации [Оскорбин, 1977;
Оскорбин, Бобков, 1997a, 1997б; и др.]. Разломная тектоника региона представлена согласно монографии под редакцией Г.А. Шаткова, А.С. Вольского [Тектоника..., 2004].

Основой для публикуемого каталога послужил в первую очередь «Новый каталог сильных землетрясений на территории СССР с древнейших времен до 1975 г.», включающий каталог землетрясений Приморья и Приамурья за 1865-1973 гг. [Новый Каталог..., 1977]. В составлении данного каталога принимали участие: А.А. Емельянова, Б.М. Козьмин (Якутский филиал СО АН СССР), Н.В. Шебалин (ИФЗ АН СССР), Л.С. Оскорбин, Н.Н. Леонова и Т.В. Нагорных (СахКНИИ ДВНЦ AH CCCP).

Каталог за те же и последующие годы был дополнен материалами из других источников [Даммер, 1971; Оскорбин, 1977; Солоненко и др., 1985; Николаев и др., 1989; Ким, Андреева, 2012; и др.], а также материалами из ежегодников «Землетрясения в СССР», начавших выходить в 1962 г. С 1975 по 2007 г. привлечены данные Сахалинской опытно-методической сейсмологической партией $(\mathrm{COMCП)/СФ} \mathrm{ГС} \mathrm{РАН,} \mathrm{опубликованные}$ в ежегодниках «Землетрясения в СССР» и «Землетрясения Северной Евразии». С 2008 по 2015 г. использованы рабочие материалы СФ ГС РАН.

Ответственными составителями каталогов, а также основными авторами статей по сейсмичности Приамурья и Приморья в сборниках «Землетрясения в СССР» и «Землетрясения Северной Евразии» являлись: Л.С. Оскорбин, Т.В. Нагорных, Л.Н. Поплавская (с 1974 по 1980 г.), А.А. Шолохова (с 1980 по 1999 г.), Н.С. Коваленко (с 1999 г. по наст. время). Автором большинства решений механизмов очагов землетрясений является М.И. Рудик.

Основная цель данной работы - представить вниманию специалистов наиболее полный каталог землетрясений региона Приамурье и Приморье, а также необходимые для работы с ним 
данные о развитии сети сейсмологических наблюдений, представительности каталога, способе приведения к единой магнитудной оценке.

Представляемый каталог ограничен периодом с 1865 г., когда появились первые данные, позволившие впоследствии установить параметры очага землетрясения, по 2015 г., последний год инструментальных измерений с применением аналоговых сейсмометров на территории региона.
Дополнительно приведен краткий анализ сейсмичности территории. На основе представленного каталога механизмов очагов землетрясений выполнена реконструкция поля тектонических напряжений в земной коре региона и участке мантии под территорией Приморья. 


\section{ГЛАВА 1}

\section{РАЗВИТИЕ РЕГИОНАЛЬНОЙ СЕТИ СЕЙСМОЛОГИЧЕСКИХ НАБЛЮДЕНИЙ}

В первой половине XX века регистрация землетрясений в рассматриваемом регионе производилась сейсмостанцией «Владивосток» (откры- та в 1929 г.) и удаленными станциями, ближайшая из которых располагалась в г. Иркутск [Николаев и др., 1989].

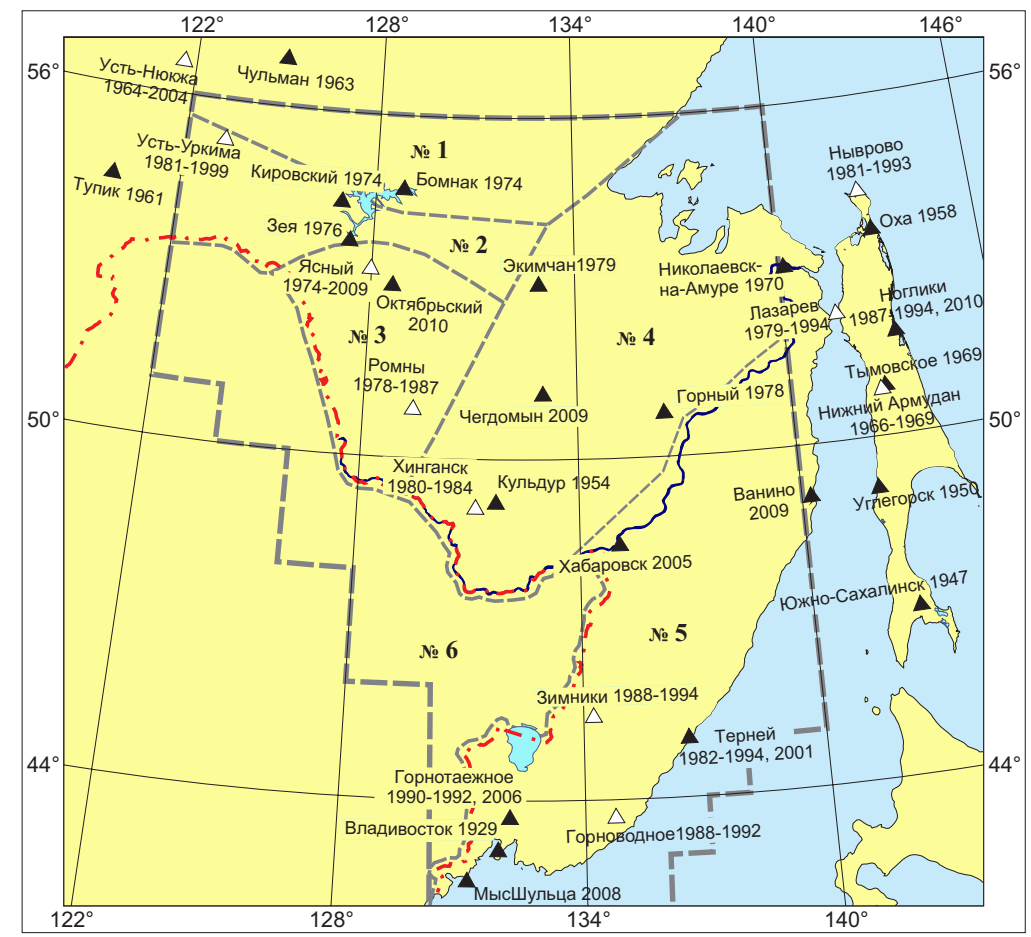

Рис. 1.1. Сейсмические станции Приамурья и Приморья и прилегающих регионов.

Указаны годы открытия и прекращения наблюдений. Черные треугольники - действующие в 2015 г., белые треугольники - закрытые.

Макросейсмические данные о землетрясениях этого периода носят отрывочный характер: первые достоверные сведения о них относятся к 60-м годам XIX в. [Мушкетов, Орлов, 1893]. Наиболее полные сводки о землетрясениях конца XIX - начала XX вв. опубликованы в [Уланов, 1932] и [Попов, 1939]. Большая работа по сбору информации и оценке численных значений параметров землетрясений была проведена в ходе подготовки «Нового каталога сильных землетрясений на территории СССР с древнейших времен до 1975 г.» [Новый каталог..., 1977].
Следующий этап в изучении сейсмичности Приамурья и Приморья начался с развития сетей сейсмических станций в соседних сейсмоактивных регионах и установки современных сейсмографов регионального типа. Так в 1951 г. созданы сейсмостанции в городах Углегорск и Южно-Сахалинск (о. Сахалин), Магадан и ПетропавловскКамчатский, в 1957 г. открылась сейсмостанция в г. Якутск, а в 1958 г. в г. Оха (о. Сахалин). Все эти сейсмостанции первоначально были оснащены сейсмографами общего типа с увеличением до 1000 на периодах 1-10 c, аппаратура СК-3, ВЭГИК. 
В 1961 г. Институт земной коры СО АН СССР и Якутский филиал СО АН СССР открыли сейсмостанции регионального типа с увеличением сейсмографов до 50000 на периодах 0.60.7 с в пос. Тупик (восток Читинской области), Усть-Нюкжа (северо-запад Амурской области) и Чульман (юг Якутии). Кроме того, СахКНИИ в 1962-1966 гг. на сейсмических станциях в г. Южно-Сахалинск, Углегорск и Оха были установлены сейсмографы регионального типа с увеличением до 30000 , а в конце 1966 г. открыта сейсмостанция регионального типа в пос. Тымовское (центральная часть Сахалина) с увеличением сейсмической аппаратуры до 100000 на периодах от 0.5-0.7 с. Значительным событием следует считать организацию в 1970 г. сейсмической станции в г. Николаевск-на-Амуре (первой станции на территории Приамурья), оснащенной сейсмографами регионального типа с увеличением до 150000 на периодах $0.5-0.7$ с. Примерно в эти же годы и другие станции переоборудуются аппаратурой СКД и CKM-3.

СахКНИИ ДВНЦ АН СССР для выполнения научно-исследовательской темы «Изучение влияния заполнения водохранилища Зейской ГЭС на изменение степени сейсмической опасности прилегающей территории» в 1974-1976 гг. организовал сейсмические станции регионального типа в пос. Бомнак, Кировский, Ясный и в г. Зея. Следующим шагом в развитии системы инструментальных наблюдений за землетрясениями было открытие в 1978-1980 гг. сейсмических станций, предназначенных для выполнения научно-исследовательских работ по изучению сейсмичности и сейсмического режима территории восточного участка зоны БАМ в пос. Горный (близ г. Комсомольск-наАмуре), Хохлатское (вблизи г. Ромны), Экимчан и Хинганск. Кроме того, в конце 1980 г. организована сейсмостанция в пос. Лазарев, расположенном южнее Николаевска-на-Амуре (Хабаровский край).

В ноябре 1980 г. на базе отдела сейсмических стационаров СахКНИИ была образована Сахалинская опытно-методическая сейсмологическая партия (СОМСП) под руководством Л.С. Оскорбина, унаследовавшая сеть сейсмических стационаров и задачу мониторинга территории Приамурья и Приморья, Сахалина и Курильских островов.

Для изучения сейсмичности южного Приморья в 1982 г. была открыта сейсмическая станция в пос. Терней, в 1988 г. - станции на юге Приморья в пос. Горноводное, Зимники, в 1990 г. в пос. Горнотаежное. В апреле 1984 г. станция «Хинганск» прекратила свою работу, вместо нее началось использование записей расположенной относительно недалеко сейсмостанции «Кульдур», принадлежащей ИФЗ АН СССР.

Таким образом, созданная сеть сейсмостанций Приамурья и Приморья совместно с близрасположенными станциями Сахалина (г. Углегорск, Оха, пос. Ныврово, Тымовское), Якутии (пос. Чульман, Чагда) и Байкальской сети (пос. Чара, Неляты, Средний Калар, Тупик) обеспечивала такой уровень представительности регистрируемых здесь землетрясений, который позволял накапливать необходимый однородный фонд исходных данных для получения объективных сейсмологических характеристик. К концу рассматриваемого периода (1991 г.) возможности сети позволяли без пропусков регистрировать землетрясения с магнитудами $M L H \geq 2.0$ на территории Амурской области и южного Приморья и $M L H \geq 3.0$ на остальной территории (рис. 2.1).

В начале 90-х годов в связи с недофинансированием сейсмические станции начали закрываться. В 1992 г. закрыты станции в пос. Горноводное, Зимники, Горнотаежное; в 1993 г. - в пос. Ныврово (о. Сахалин), в 1994 г. - в пос. Лазарев, Терней, Ноглики, г. Оха (о. Сахалин), в 1995 - в пос. Тунгурча (Якутия), в 1998 г. - Средний Калар (Байкал); в 1999 г. - в пос. Усть-Уркима (Якутия). Ухудшение конфигурации сети сейсмических станций привело к снижению представительности регистрации землетрясений, особенно в Приморье, фактически прежние регистрационные возможности остались только в Амурской области благодаря сети мониторинга Зейского приводохранилищного района.

Катастрофическое Нефтегорское землетрясение 28 мая 1995 г. напомнило о важности сейсмического мониторинга Дальнего Востока. В дальнейшем СОМСП, вошедшая в апреле 1995 г. в состав Геофизической службы РАН, старалась всеми силами поддерживать существующую сеть станций, изыскивая возможности для настройки и ремонта устаревающей аналоговой аппаратуры.

Первой широкополосной цифровой станцией в зоне ответственности Сахалинского ОМСП можно считать комплекс аппаратуры (датчики Streckeisen STS-1, Geotech GS-13), установленной в мае 1992 г. на сейсмостанции «Южно-Сахалинск» в соответствии с «Соглашением о сотрудничестве в области наблюдательной сейсмологии для поддержки фундаментальных и прикладных исследований» в рамках Российско-американского межправительственного соглашения по экономическому и техническому сотрудничеству [Спирин, Левин, 2008], впрочем, на представительности каталога землетрясений Приамурья и Приморья это не сказалось. 
С мая 2005 г. сейсмостанция «Владивосток» перестала передавать информацию в отдел сводной обработки СФ ГС РАН; фактически и до этого момента полезных данных от этой станции поступало мало в связи с неудачным ее расположением в центре города.

Переход на цифровую аппаратуру в Приамурье и Приморье начался только в 2005-2006 гг., когда в рамках Соглашения о научном сотрудничестве по проекту «Исследования сейсмотектоники Охотоморской плиты» между Сообществом университетов Японии, с одной стороны, и институтами Российской академии наук и Геофизической службой РАН, с другой, на базе сейсмостанций «Зея», «Горный», «Терней», в г. Хабаровск на территории ИТиГ ДВО РАН, на базе астрофизической обсерватории в пос. Горнотаежный, а также на Сахалине на базе сейсмических стационаров «Оха» и «Тымовское» были установлены комплекты аппаратуры, включающие регистратор Datamark LS7000XT, трехкомпонентные датчики: широкополосный STS-2, короткопериодный L4C$3 \mathrm{D}$, системы связи и привязки по времени к GPS. В августе 2007 года в пос. Охотск на севере Хабаровского края был установлен еще один комплект аппаратуры с Datamark. Впрочем, к обработке новых цифровых данных удалось приступить не сразу ввиду неадаптированности методов обработки, программного обеспечения и отсутствия опыта у операторов.

В октябре 2008 г. на геофизическом полигоне ТОИ ДВО РАН (г. Владивосток) «Мыс Шульца» в рамках проекта «Развитие сети сейсмологических наблюдений и средств обработки и передачи данных в целях предупреждения о цунами» федеральной целевой программы «Снижение рисков и смягчение последствий чрезвычайных ситуаций природного и техногенного характера в Российской Федерации до 2010 г.» сотрудниками Камчатского филиала Геофизической службы РАН и ТОИ ДВО РАН установлен широкополосный велосиметр Guralp CMG-3ESPB [Долгих и др., 2010].

B рамках комплексной программы поддержки фундаментальных исследований ДВО «Современная геодинамика, активные геоструктуры и природные опасности Дальнего Востока России» на территории Приамурья и о. Сахалин в 2009 г. сотрудниками ИМГиГ ДВО РАН и ИТИГ ДВО РАН (г. Хабаровск) был установлен ряд цифровых сейсмостанций. Аппаратный комплекс включает трехкомпонентный широкополосный сейсмометр RefTek 151-120, цифровой регистратop RefTek 130-01 и GPS-приемник [Ханчук и др., 2011]. Приборы были установлены в населенных пунктах Чегдомын, Ванино, Благовещенск, на базе сейсмических станций о. Сахалин «Углегорск» и «Южно-Сахалинск» и станции «Николаевск» в Приамурье. Только для части станций удалось наладить постоянную непрерывную работу. Данные с пунктов установки «Чегдомын» и «Ванино» начали поступать в отдел сводной обработки СФ ГС РАН и привлекаться для пополнения каталогов землетрясений Приамурья и Приморья.

В связи с фактическим закрытием пос. Ясный Амурской области, в апреле 2009 г. сейсмостанция «Ясный» была остановлена, аналоговое оборудование было перенесено во вновь открывшийся сейсмический стационар в пос. Октябрьский, который начал работу в январе 2010 г.

В 2010 г. в Сахалинском филиале Геофизической службы РАН в смежном регионе о. Сахалин в рамках упоминавшейся федеральной целевой программы «Снижение рисков и смягчение последствий чрезвычайных ситуаций природного и техногенного характера в РФ до 2010 г.» были установлены трехкомпонентные датчики широкополосного велосиграфа CMG-6TD и акселерографа CMG-5T/TD на сейсмостанциях «Углегорск» и «Тымовское», а также во вновь открытых «Новоалександровск» и «Ноглики». В 2011 г. комплект аппаратуры Guralp был установлен на приморской сейсмостанции «Терней».

С 2011 г. регистрация аналоговой аппаратурой на всех станциях о. Сахалин остановлена, в 2012 г. остановлено аналоговое оборудование на станции «Терней».

В декабре 2012 г. на сейсмостанции «Зея» установлен цифровой регистратор UGRA с полным комплектом сейсмоприемников СМ-3КВ-1. В июне 2013 г. комплекс UGRA+CM-3ОС установлен и введен в эксплуатацию на сейсмостанции «Николаевск-на-Амуре». Это позволило остановить 30 сентября 2013 г. на станции все аналоговые регистраторы. 12 октября 2013 г. на сейсмостанции «Николаевск-на-Амуре» дополнительно установлен акселерометр Guralp CMG-5TDE. 30 ноября 2013 г. все аналоговые регистраторы остановлены на станции «Горный». В августе 2014 г. цифровые акселерометры Guralp CMG-5TDE установлены на сейсмостанциях «Зея», «Кировский» и «Октябрьский», а в октябре - на сейсмостанции «Экимчан». Аналоговая регистрация на сейсмостанции «Зея» остановлена.

21 сентября 2015 г. на сейсмостанции «Экимчан» установлен и запущен в работу регистрирующий комплекс Datamark в составе сейсмометров STS-2, L4C-3D и регистратора LS7000XT. 17 октября на последней сейсмостанции с только аналоговым оборудованием «Бомнак» установлен цифровой регистратор акселерометр Guralp CMG5TDE. 30 сентября 2015 г. остановлены и демонтированы последние регистраторы с аналоговой 
формой записи СКМ-3 и аппаратура СЗСЗ ждущего режима на сейсмостанциях третьего класса Зейского куста. Таким образом, аналоговая реги- страция на территории Приамурья и Приморья прекратилась.

Таблица 1. Сведения о работе сейсмических станций на территории Приамурья и Приморья.

\begin{tabular}{|c|c|c|c|c|c|c|c|}
\hline \multirow{2}{*}{$\begin{array}{c}\text { Пункт } \\
\text { наблюдения } \\
\text { (организация) })^{2}\end{array}$} & \multirow{2}{*}{$\begin{array}{c}\text { Код } \\
\text { станции }\end{array}$} & \multicolumn{2}{|c|}{ Координаты } & \multicolumn{2}{|c|}{$\begin{array}{c}\text { Аналоговая } \\
\text { аппаратура }\end{array}$} & \multirow{2}{*}{$\begin{array}{c}\begin{array}{c}\text { Цифровая } \\
\text { аппаратура }\end{array} \\
\text { начало } \\
\text { работы }\end{array}$} & \multirow{2}{*}{ Примечания } \\
\hline & & широта & долгота & $\begin{array}{l}\text { начало } \\
\text { работы }\end{array}$ & $\begin{array}{c}\text { конец } \\
\text { работы }\end{array}$ & & \\
\hline \multicolumn{8}{|c|}{ Сейсмические станции на территории Приамурья и Приморья } \\
\hline $\begin{array}{l}\text { Владивосток } \\
\text { (ГС РАН) }\end{array}$ & $\begin{array}{l}\text { ВЛД } \\
\text { VLA }\end{array}$ & 43.12 & 131.89 & 12.1929 & $(2005)$ & 07.2005 & $\begin{array}{l}\text { В 2005-2015 гг. данные не поступали в } \\
\text { центр обработки СФ ГС РАН }\end{array}$ \\
\hline $\begin{array}{l}\text { Кульдур } \\
\text { (ГС РАН) }\end{array}$ & $\begin{array}{l}\text { КЛД } \\
\text { KLR }\end{array}$ & 49.23 & 131.75 & $\begin{array}{c}09.1954 \\
(1984)\end{array}$ & 10.2010 & $(09.2015)$ & \begin{tabular}{|l} 
Использование в сводной обработке \\
началось с 1984 г. \\
2013-2015 гг. данные были не доступны \\
\end{tabular} \\
\hline $\begin{array}{c}\text { Николаевск-на- } \\
\text { Амуре } \\
\text { (СФ ГС РАН) }\end{array}$ & $\begin{array}{l}\text { НКЛ } \\
\text { NKL }\end{array}$ & 53.15 & 140.68 & 07.1970 & 09.2013 & 2009 & \\
\hline $\begin{array}{c}\text { Кировский } \\
\text { (СФ ГС РАН) }\end{array}$ & $\begin{array}{c}\text { KPC } \\
\text { KROS }\end{array}$ & 54.43 & 126.98 & 04.1974 & 09.2015 & 08.2014 & \\
\hline $\begin{array}{c}\text { Бомнак } \\
(\mathrm{CФ} \mathrm{ГС} \mathrm{РАН})\end{array}$ & $\begin{array}{c}\text { БMH } \\
\text { BMKR }\end{array}$ & 54.71 & 128.85 & 11.1974 & 09.2015 & 09.2015 & \\
\hline $\begin{array}{c}\text { Ясный } \\
\text { (СФ ГС РАН) }\end{array}$ & $\begin{array}{c}\text { 9CH } \\
\text { YASR }\end{array}$ & 53.29 & 127.98 & 12.1974 & 05.2009 & & \\
\hline $\begin{array}{l}\text { Зея (СФ ГС } \\
\text { РАН })\end{array}$ & $\begin{array}{l}\text { 3EЯ } \\
\text { ZEA }\end{array}$ & 53.76 & 127.29 & 06.1976 & 08.2014 & 07.2006 & \\
\hline $\begin{array}{c}\text { Горный } \\
\text { (СФ ГС РАН })\end{array}$ & $\begin{array}{c}\text { ГPH } \\
\text { GRNR }\end{array}$ & 50.76 & 136.45 & 12.1978 & 11.2013 & 08.2005 & \\
\hline $\begin{array}{c}\text { Ромны } \\
\text { (СОМСП) }\end{array}$ & PMH & 50.72 & 129.29 & 10.1978 & 12.1987 & & \\
\hline $\begin{array}{c}\text { Экимчан } \\
\text { (СФ ГС РАН) }\end{array}$ & $\begin{array}{c}\text { ЭKM } \\
\text { EKMR }\end{array}$ & 53.07 & 132.95 & 12.1979 & 09.2015 & 08.2014 & \\
\hline $\begin{array}{l}\text { Хинганск } \\
\text { (СОМСП) }\end{array}$ & ХНГ & 49.129 & 131.189 & 07.1980 & 04.1984 & & \\
\hline $\begin{array}{c}\text { Лазарев } \\
\text { (СОМСП) }\end{array}$ & ЛЗР & 52.168 & 141.50 & 12.1979 & 03.1994 & & \\
\hline $\begin{array}{c}\text { Терней } \\
(\text { СФ ГС РАН) }\end{array}$ & $\begin{array}{l}\text { TЕЙ } \\
\text { TЕY }\end{array}$ & 45.06 & 136.60 & $\begin{array}{l}09.1982 \\
10.2001\end{array}$ & 03.1994 & 09.2005 & \\
\hline $\begin{array}{c}\text { Горноводное } \\
\text { (СОМСП) }\end{array}$ & ГРВ & 43.73 & 134.25 & 07.1988 & 09.1992 & & \\
\hline $\begin{array}{l}\text { Зимники } \\
\text { (СОМСП) }\end{array}$ & $3 \mathrm{MH}$ & 45.47 & 134.25 & 07.1988 & 03.1994 & & \\
\hline $\begin{array}{l}\text { Горнотаежное } \\
\text { (СФ ГС РАН) }\end{array}$ & $\begin{array}{c}\text { ГPT } \\
\text { GRTR }\end{array}$ & 43.70 & 132.16 & 06.1990 & 04.1992 & 08.2006 & \\
\hline $\begin{array}{c}\text { Хабаровск } \\
\text { (СФ ГС РАН) }\end{array}$ & $\begin{array}{c}\text { XБР } \\
\text { KHВR }\end{array}$ & 48.47 & 135.05 & & & 08.2005 & \\
\hline $\begin{array}{l}\text { Мыс Шульца } \\
\text { (ГС РАН) }\end{array}$ & MSH & 42.58 & 131.16 & & & 10.2008 & \\
\hline $\begin{array}{c}\text { Чегдомын } \\
\text { (ИТИГ ДВО } \\
\text { РАН) }\end{array}$ & $\begin{array}{l}\text { CHMN } \\
\text { A720 }\end{array}$ & 51.14 & 133.04 & & & 2009 & \\
\hline $\begin{array}{c}\text { Ванино (ИТИГ } \\
\text { ДВО РАН) }\end{array}$ & $\begin{array}{l}\text { VNNI } \\
\text { A732 }\end{array}$ & 49.09 & 140.25 & & & 2009 & \\
\hline $\begin{array}{l}\text { Октябрьский } \\
\text { (СФ ГС РАН) }\end{array}$ & $\begin{array}{c}\text { OKT } \\
\text { OCTB }\end{array}$ & 53.02 & 128.64 & 01.2010 & 09.2015 & 08.2014 & \\
\hline
\end{tabular}

1 СЗС3 - сейсмографы записи сильных землетрясений, различные устройства, такие как сейсмоскоп СБМ (прибор для определения балльности), велосиграф С5С, акселерографы ОСП 2-М, ССРЗ-М и другие устройства, основная задача которых - регистрация максимальных амплитуд колебаний для определения динамических характеристик землетрясения в ближней зоне. Работают, как правило, в ждущем режиме и запускаются после получения сигнала с датчиков непрерывной регистрации, потому наличие или отсутствие подобной аппаратуры не влияет на факт регистрации землетрясений. К тому же, в связи с практически полным отсутствием сильных землетрясений на территории Приамурья и Приморья, эффективность использования подобной аппаратуры на региональных сейсмостанциях невелика. Однако различные устройства СЗСЗ вели регистрацию на станциях Приамурья и Приморья (кроме станции «Ясный») вплоть до 2015 г.

2 Указана принадлежность к организации на 2015 г. либо на момент закрытия пункта наблюдения. 


\section{ГЛАВА 2}

\section{ПРЕДСТАВИТЕЛЬНОСТЬ КАТАЛОГА ЗЕМЛЕТРЯСЕНИЙ}

Представительные землетрясения - это землетрясения заданного энергетического уровня, которые не только регистрируются без существенных пропусков данной сетью сейсмических станций, но и эпицентры которых не содержат систематических ошибок.

В общем случае представительность землетрясений существенным образом зависит от трех следующих факторов: регистрационных возможностей сети сейсмических станций, конфигурации сети станций и возможностей имеющегося в региональном центре обработки методического (алгоритмического) обеспечения задачи определения основных параметров сейсмического события.

На основе данных о работе сейсмических станций (табл. 1) были составлены таблицы их информативности (количество землетрясений, зарегистрированных сейсмостанцией в \% от общего числа зарегистрированных событий) [Кондорская, Федорова, 1996; Старовойт, Мишаткин, 2001]. Подобные таблицы составлены для магнитудных диапазонов $\mathrm{M}=2.3-2.7 ; 2.8-3.2$ и т.д. с интервалом 0.5 М. По составленным таблицам реальной информационной обеспеченности был проведен численный эксперимент с сетью станций с использованием базовых алгоритмов регионального центра сбора и обработки данных (комплекса программ MGP) [Нагорных, Поплавская, 2003; Поплавская и др., 1989; Бобков, 1989]. Анализ результатов численного эксперимента показал, что устойчивое решение задачи об эпицентре землетрясения методом прямых волн можно получить по данным не менее 3-4 сейсмических станций (по наблюдениям прямых продольных и поперечных волн). Если же использовался метод минимизации невязок к годографу первых вступлений, то для достоверной локализации эпицентра корового землетрясения необходимы данные 5-8 сейсмических станций. В противном случае эпицентры оказываются смещенными за пределы их территориальной принадлежности [Нагорных, Поплавская, 2003] и, следовательно, не будут представительными на изучаемом участке эпицентрального поля. Само поле будет деформировано, а каталог землетрясений будет содержать систематические ошибки [Токарева, 1991; Урбан и др., 1996].
В статье [Нагорных, Поплавская, 2003] подробно описывается построение таблиц информативности сейсмических станций Дальнего Востока и карты-схемы численного эксперимента. Более подробно остановимся на картах представительности землетрясений Приамурья и Приморья.

За 1961-2006 гг. можно выделить 18 периодов развития сети сейсмических станций. Для каждого из них были проведены исследования, позволяющие учесть влияние упомянутых трех факторов на оценку представительности землетрясений заданной энергии (магнитуды) на конкретном участке эпицентрального поля.

Представительность коровых землетрясений Дальнего Востока менялась по мере изменения численного состава и конфигурации наблюдающих станций. Так, например, в 1961-1966 гг. землетрясения с $\mathrm{M}=3.8-4.2$ были представительны лишь на небольшом участке изучаемой территории (северо-запад Приамурья) (рис. 2.1). Наилучшая информационная обеспеченность достигнута в 1990-1992 гг. В рассматриваемый период времени на территории региона и о. Сахалин работало 20 сейсмических станций, что повысило представительность землетрясений по всему региону Приамурье и Приморье до $\mathrm{M} \geq 3.3$ (рис. 2.1).

Следует отметить, что карты представительности за период 1961-1974 гг. скорее имеют смысл карт дальности регистрации (регистрационных возможностей), чем карт представительности, поскольку для этого периода наблюдений в регионе Приморья и Приамурья численного эксперимента не проводилось. Заключение о разрешимости задачи об эпицентре в 1961-1974 гг. осуществлялось по аналогии с результатами численных экспериментов, выполненных для периодов детального изучения сейсмичности (1974-1992 гг.). Такое сопоставление позволило из карт регистрационных возможностей за 1961-1974 гг. [Оскорбин, 1977] составить карты представительности землетрясений соответствующих энергий. Немаловажно отметить, что такое сопоставление позволило также наметить для пересмотра положения ряда землетрясений с помощью более рациональных и современных алгоритмов. 

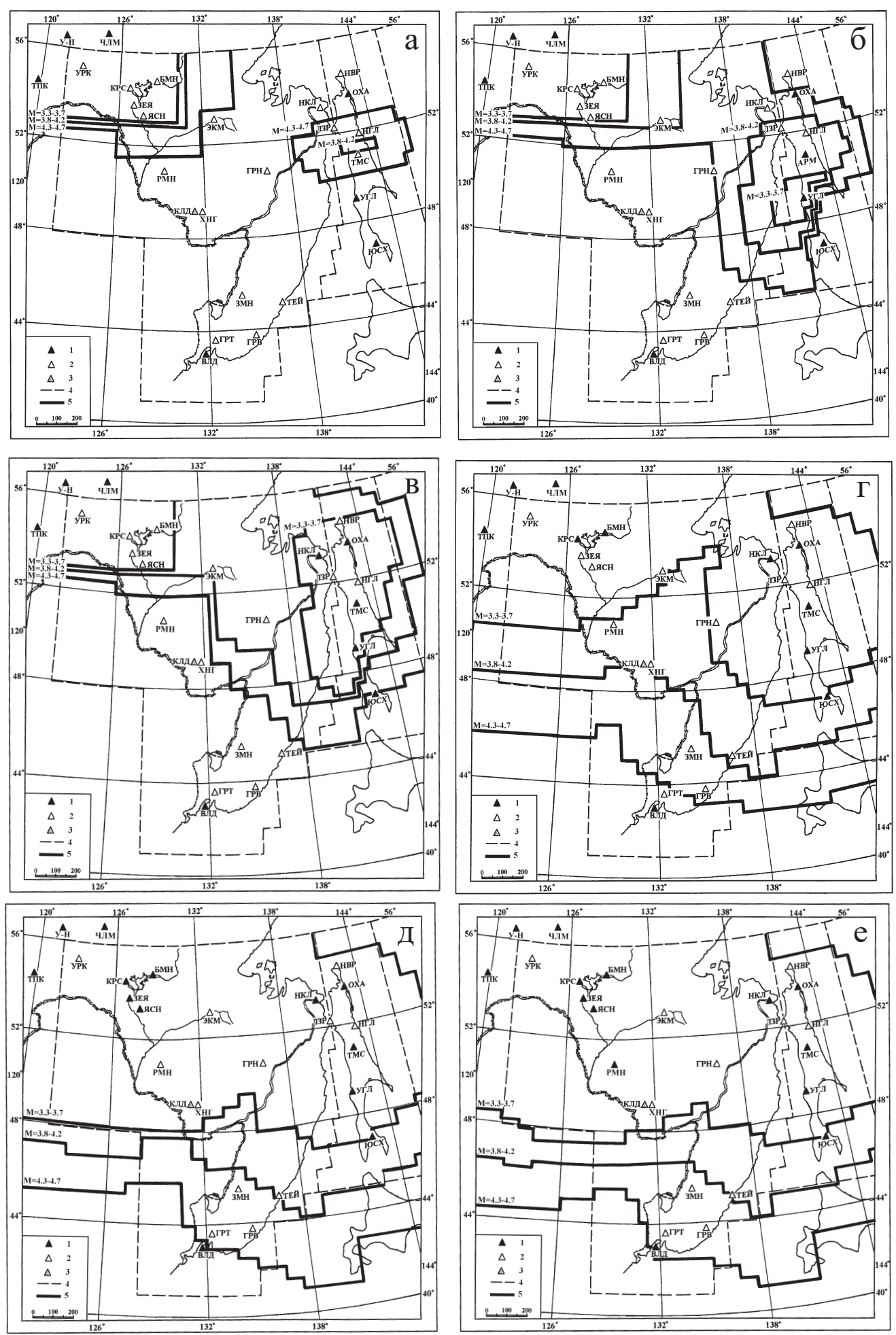

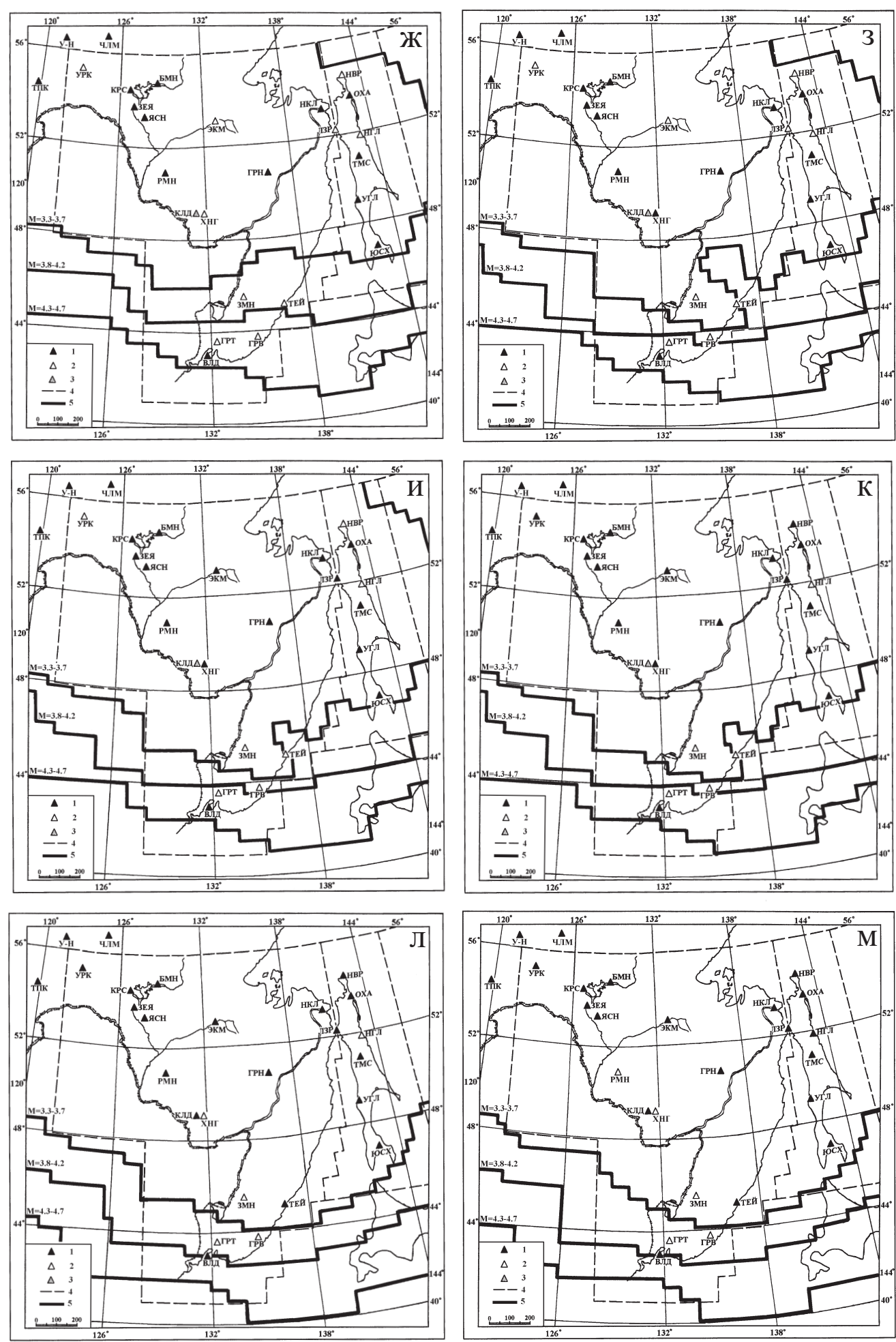

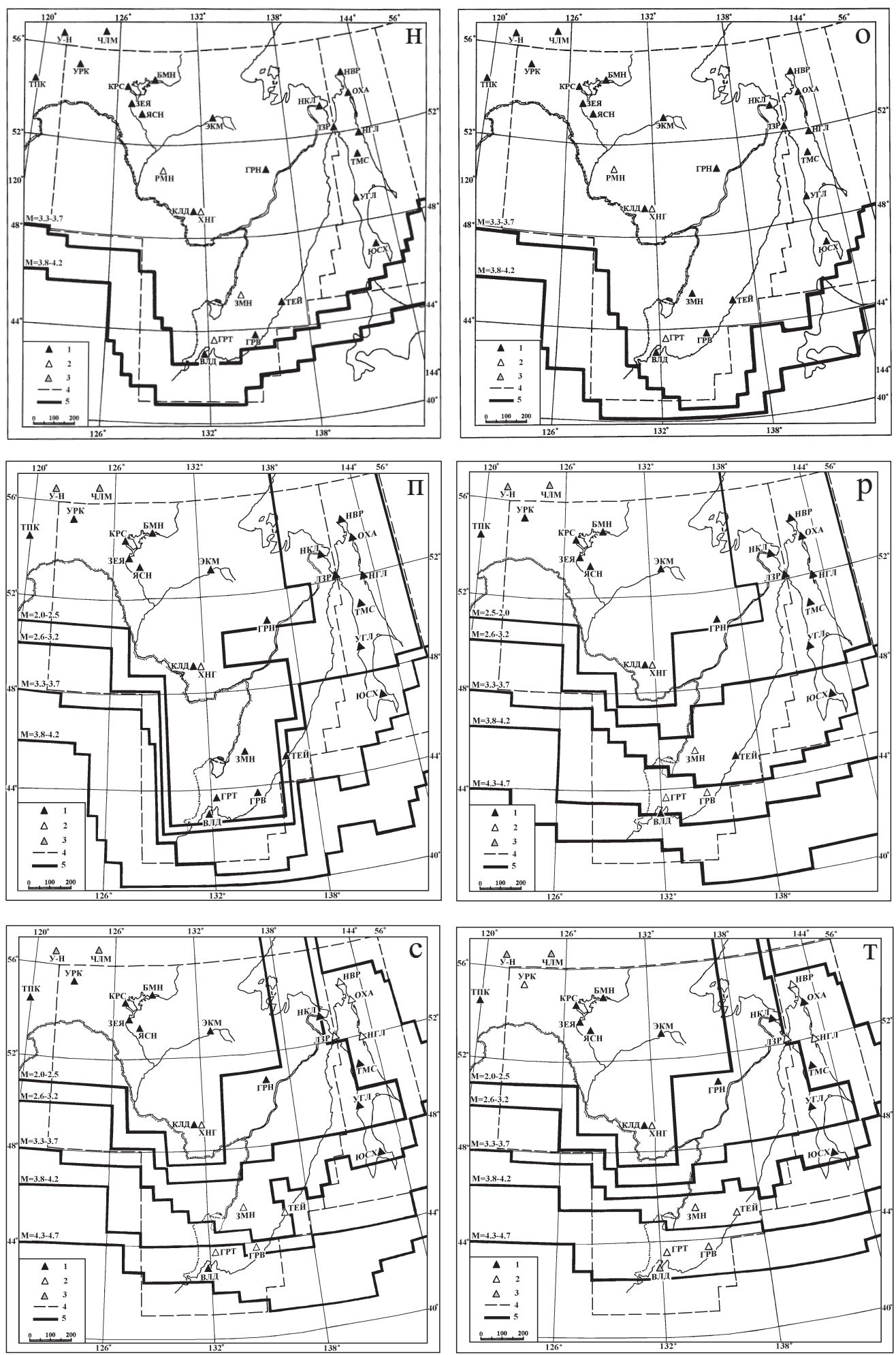

Рис. 2.1. Карты представительности землетрясений в регионах Приамурье и Приморье, о. Сахалин за период наблюдений 1961-2006 гг. (по интервалам изменения регистрации землетрясений). 1-3 - сейсмические станции: 1 - действующие; 2 - закрытые; 3 - отсутствуют данные со станций; 4 - границы регионов Приамурье и Приморье, Сахалинского; 5 границы представительности соответствующих магнитуд; а - 01.01.1961-31.12.1966 гг.; б - 01.01.1967-31.12.1970 гг.; в - 01.01.1971-01.04.1974 гг.; г - 02.04.1974-24.12.1974 гг.; д - 25.12.1974-17.10.1978 гг.; е - 18.10.1978-07.12.1978 гг.; ж-08.12.1978-10.04.1979 гг.; з - 11.04.1979-24.11.1979 гг;; и - 25.11.1979-01.11.1981 гг; к-01.11.1981-26.08.1982 гг; л - 27.08.1982-01.12.1987 гг.; м - 01.12.1987-13.07.1988 гг;; н - 14.07.1988-19.07.1988 гг.; о - 20.07.1988-30.05.1990 гг.; п - 01.06.1990-03.1992 гг.; p - 04.1992-12.1993 гг.; с -01.1994-05.1995 гг.; т - 06.1995-01.2006 гг. 
Начиная с 2007 г. карты регистрационных возможностей сети сейсмостанций для территории Приамурья и Приморья строились для отчетов о работе СФ ГС РАН по факту дальности регистрации землетрясений определенного энергетического уровня не менее чем тремя станциями региона без проведения численного эксперимента, поэтому осреднения карт по координатной сетке также не выполняется. Как сказано выше, такой подход более грубый и не может гарантировать представительность получаемого сетью каталога в указанных границах, помогая лишь примерно оценить регистрационную возможность сети. На рис. 2.2 и 2.3 показаны карты регистрационных возможностей региональной сети сейсмостанций (с учетом ближайших станций соседних сетей ГС РАН) в 2007-2008 и 2009-2015 гг.

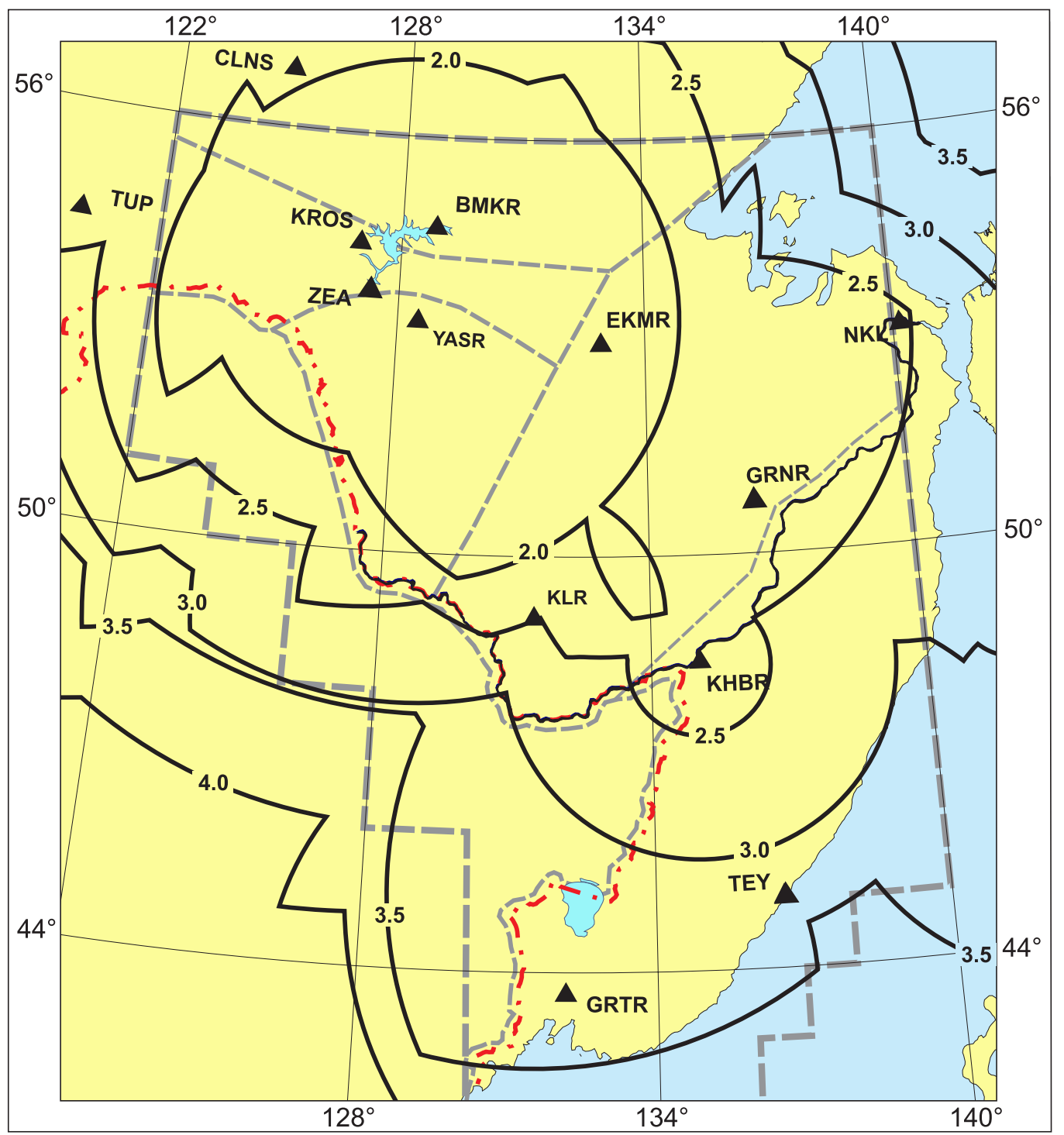

Рис. 2.2. Карта регистрационных возможностей сети ГС РАН в регионе Приамурье и Приморье в период наблюдений 2007-2008 гг. 


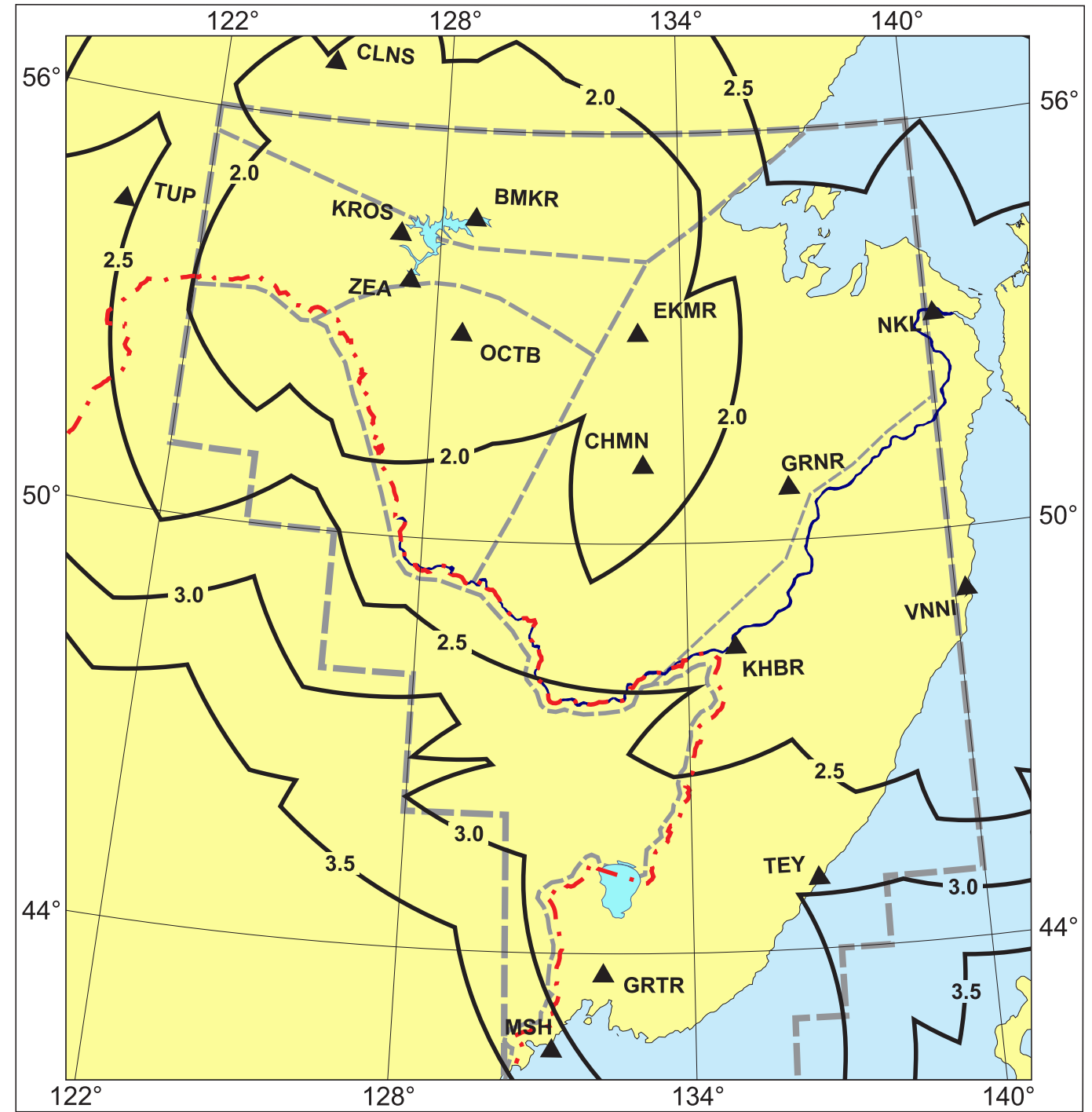

Рис. 2.3. Карта регистрационных возможностей сети ГС РАН в регионе Приамурье и Приморье в период наблюдений 2009-2015 гг. 


\section{ГЛАВА 3}

\section{СТРУКТУРА КАТАЛОГОВ ЗЕМЛЕТРЯСЕНИЙ}

Представляемый каталог землетрясений стал итогом обработки большого числа источников сейсмологической информации. Основная часть этих данных ранее была опубликована, источники указаны во введении.

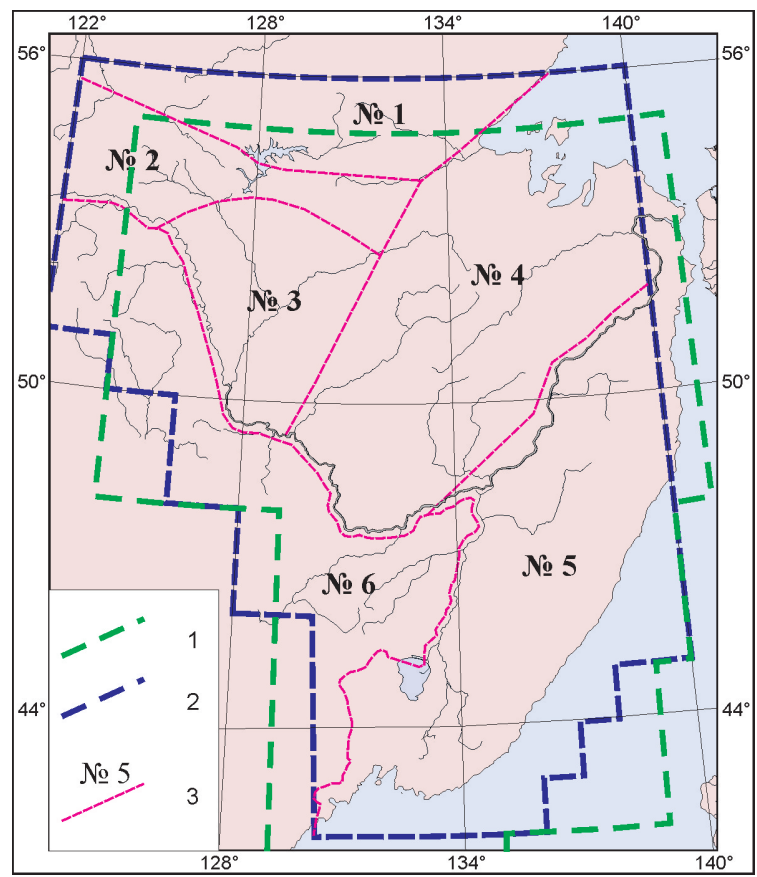

Рис. 3.1. Регион Приамурье и Приморье. Территориальное деление. 1 - границы Приамурья и Приморья по данным [Новый каталог..., 1977]; 2 - зона ответственности за сейсмологический мониторинг Приамурья и Приморья СФ ГС РАН (по состоянию на 2015 г.); 3 - разделение территории Приамурья и Приморья на районы.

Охватываемая территория. Территория, для которой осуществлялся сбор сейсмологической информации, несколько неопределенна по границам. Дело в том, что основой для базового каталога по 1975 г. был «Новый каталог сильных землетрясений на территории СССР с древнейших времен до 1975 г.» [Новый каталог..., 1977], где границы территории несколько отличаются от нынешних границ регионов, принятых в практике сейсмологических наблюдений ГС РАН (рис. 3.1). Да и границы территории Приамурья и Приморья СФ ГС РАН (СахКНИИ ДВНЦ АН СССР, СОМСП РАН) также менялись со временем. Поскольку большая часть землетрясений зарегистрирована в последние десятилетия, текущие границы регионов по ГС РАН [Коваленко и др., 2010] взяты за основу. В этих границах собрана вся доступная информация, включая ранние источники по соседним регионам. Однако в некоторых случаях часть землетрясений выходит за их рамки, поскольку присутствует в других источниках, ссылающихся на регион Приамурье и Приморье. Часть таких событий, например, на побережья Татарского пролива, по сути, является закономерным продолжением сейсмичности региона. Их было решено оставить в каталоге, в случае необходимости их несложно отфильтровать по координатам. Следует, однако, иметь в виду, что полнота каталога за границами зоны ответственности СФ ГС РАН (рис. 3.2) не соблюдается.

Структура каталога землетрясений. Каталог землетрясений региона Приамурье и Приморье содержит информацию о 12329 землетрясениях, произошедших на территории региона с 27 июня 1865 г. по 31 декабря 2015 г. Информация о землетрясениях получена по инструментальным либо макросейсмическим данным.

В каталоге представлена информация о дате и времени в очаге землетрясения $t_{0}$ с точностью определения (если такая информация была в первоисточнике), географических координатах и глубине очага (либо вероятном диапазоне глубин) с указанием точности их определения. Приведены непосредственно измеренные данные об энергетических характеристиках землетрясений либо для ранних событий - данные, полученные по макросейсмическим материалам. Для некоторых событий приводятся интенсивность в макросейсмическом эпицентре $I_{0}$ и известные оценки макросейсмического воздействия в населенных пунктах. 


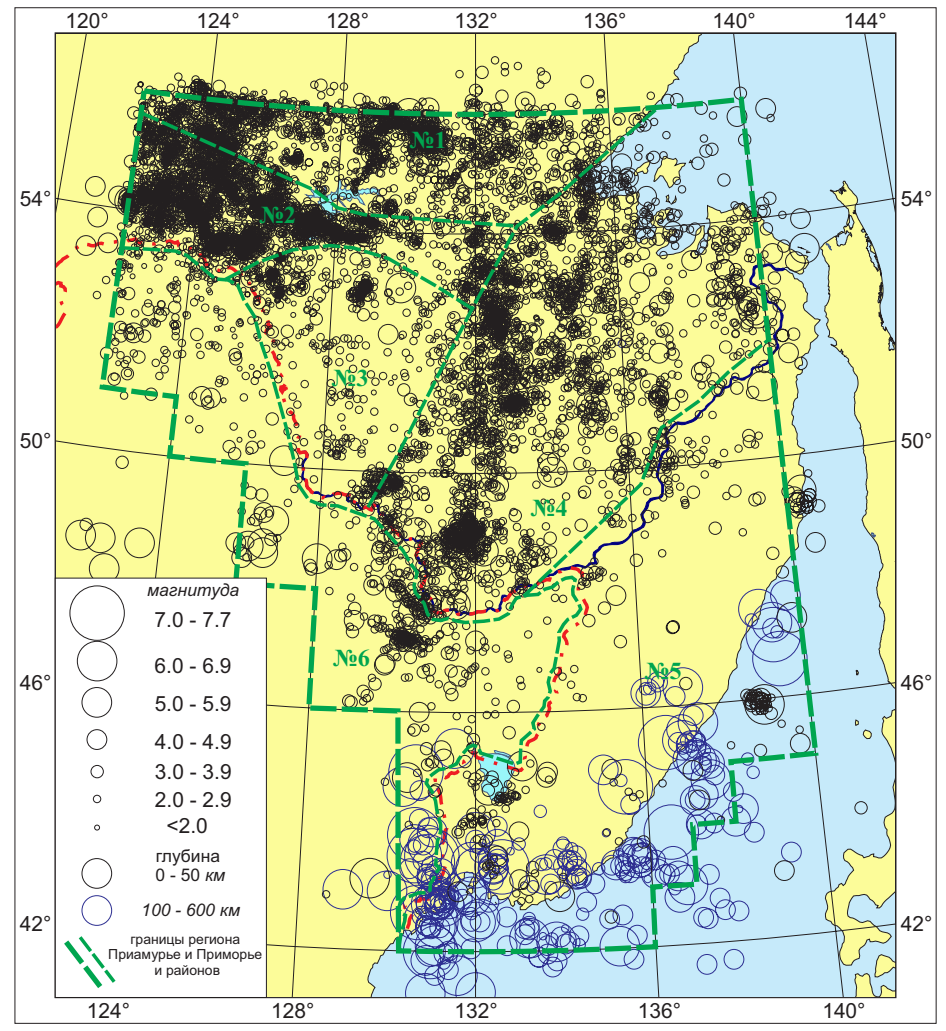

Рис. 3.2. Эпицентры всех землетрясений каталога (Приложение 1). Пунктиром показано положение границы зоны ответственности СФ ГС РАН на 2015 г. и районов внутри региона.

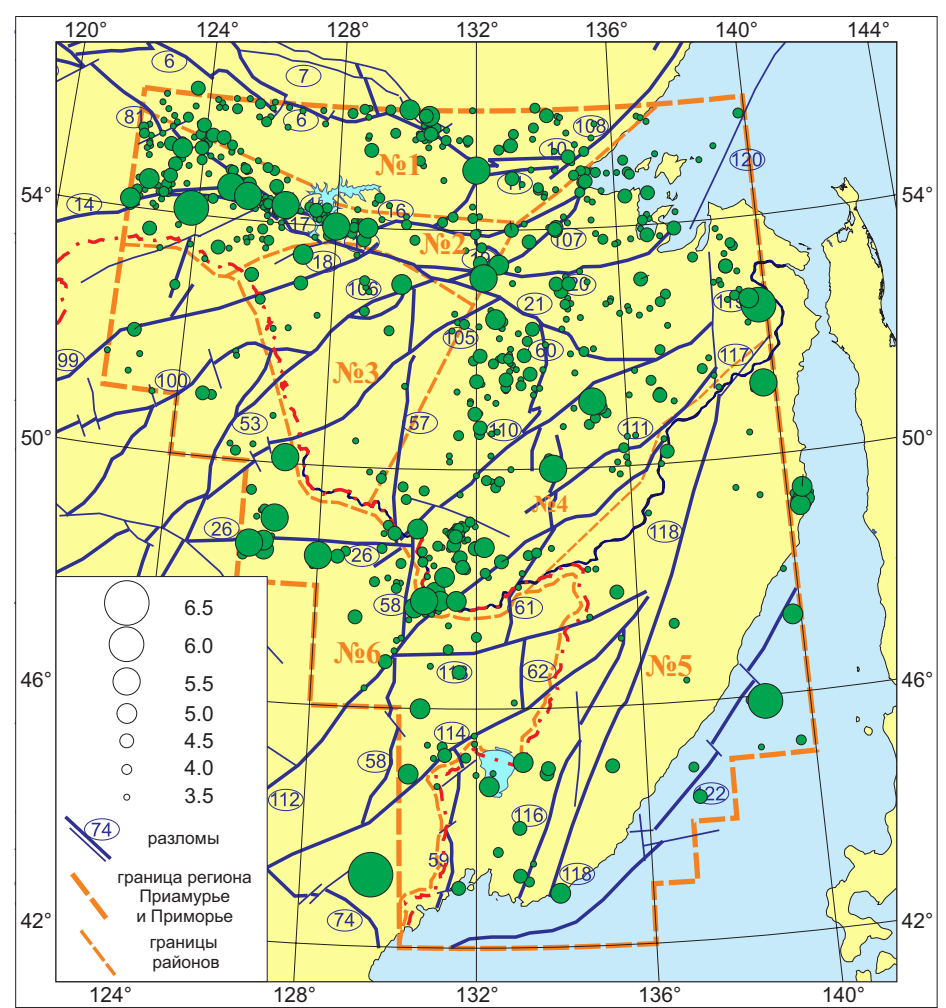

Рис 3.3. Эпицентры коровых землетрясений Приамурья и Приморья за период 1865-2015 гг., M $\geq 3.3$. Схема разломов приведена согласно [Тектоника..., 2004]. 
Глава 3. Структура каталогов землетрясений и очистка от взрывов

Поскольку весь каталог землетрясений довольно объемный, была сделана дополнительная выборка из 1043 событий с магнитудой $\mathrm{M} \geq 3.3$, которая представлена в Приложении $1 \mathrm{~A} \mathrm{c} \mathrm{не-}$ сколько уменьшенным количеством столбцов. Полная версия каталога представлена в электронной форме на CD.

Магнитудно-энергетическая оценка землетрясений. По 1974 г. в каталоге использовались магнитудные оценки первоисточников [Новый каталог..., 1977; Даммер, 1971; Оскорбин, 1977; Солоненко и др., 1985; Андреева, Ким, 2012]. В большинстве случаев под магнитудой М каталогов понимается магнитуда по поверхностной волне $M L H$, однако не во всех каталогах это уточняется. Потому в каталоге графа базовой магнитуды обозначена $M / M L H$. Методика определения магнитуды по макросейсмическим данным описана в работе [Новый каталог..., 1977].

С 1975 г. использовались данные СОМСП/ СФ ГС РАН. Здесь, как и в «Новом каталоге», приоритет отдавался магнитуде $M L H$, определяемой по соотношению $A / T$ в максимальной фазе поверхностной волны на записях горизонтальных компонент низкочастотной аппаратуры (CK, СКД), однако число землетрясений, для которых она была непосредственно определена, невелико. Наиболее массовой энергетической характеристикой приамурских и приморских коровых землетрясений был энергетический класс Т.Г. Раутиан [1964] Кр, определяемый по соотношению $A / T$ в максимальной фазе $S$-волн, записанных короткопериодной аппаратурой (СКМ, ВЭГИК) непосредственно либо в цифровой эмуляции, он пересчитывался в магнитуду по формуле [Раутиaн, 1964]:

$$
K p=1.8 M L H+4 .
$$

Для глубоких землетрясений (глубже 80 км) магнитуда $M L H$ в современной практике ГС РАН не используется, однако есть формулы для ее связи с другими магнитудными шкалами. Наиболее употребимой для исследуемого региона является магнитуда $M S H$ для аппаратуры тип С либо ее аналог для аппаратуры тип A - MSHA. Для пересчета в $M L H$ использовалась формула [Волкова и др., 1989]:

$$
M L H=(M S H(M S H A)-1.71) / 0.75 \text {. }
$$

Для случаев, когда MSH(MSHA) не была определена, пересчет велся из магнитуды $m b$ [Кондорская, Соловьев, 1974]:

$$
M L H=0.685 m b+1.47 \text {. }
$$

В отдельных случаях за ранние годы вышеприведенные магнитудные оценки отсутствуют, зато приведены значения $M L H$, кото- рые были оставлены без изменений. Наконец, если все другие магнитуды не были определены, использовались значения магнитуды MPVA (по волне $P V$ в ближней зоне) [Кондорская и др., 1993; Оскорбин, Соловьева, 1980]:

$$
M L H=1.77 M P V A-5.2 \text {. }
$$

Таким образом, все многообразие энергетических оценок сведено к одной магнитудной шкале.

Фильтрация взрывов. Начиная с середины 70-х годов прошлого столетия на территории Приамурья и Приморья появилась возможность регистрации и изучения слабой сейсмичности. Однако задачи по распознаванию природы сейсмических событий в это время не ставились. В результате в окончательные каталоги землетрясений попадали взрывы, образуя на картах эпицентров землетрясений ложные очаговые зоны и искажая реальное представление о естественной сейсмичности региона.

Задачи, возникшие в результате освоения территории Приамурья и Приморья, связанные со строительством энергетических объектов, железнодорожных и автомобильных магистралей, нефтепроводов, добычей полезных ископаемых подтолкнули к изучению природы каждого регистрируемого события. То есть необходимо было определить, является ли исследуемое событие естественным землетрясением тектонического происхождения или техногенным (т.е. взрывом).

В настоящее время для выявления взрывов используются простые правила - анализируется вид записи землетрясения, место события, время события, поиск подтверждения взрывных площадок в Google Earth, где неплохо просматриваются карьеры - последствия произведенных взрывов. Используются также сообщения СМИ о планах по разработке месторождений, строительству дорог, гидросооружений и других строящихся промышленных объектов.

Попытки выявления взрывов предпринимались в течение всего инструментального периода наблюдений. Более успешными они стали в восьмидесятые годы по мере развития сети станций, когда появилась возможность более детально анализировать и интерпретировать волновые картины сейсмических событий. Большей частью это относится к территории Амурской и Еврейской автономной областей, где более плотная сеть сейсмических станций позволяет регистрировать землетрясения с $M=2.0$. В связи с редкой сетью сейсмических станций на территории Хабаровского и Приморского краев, слабую сейсмичность отследить сложно. Здесь каталог, чаще всего, представлен событиями с $M \geq 3.0$, что выше энергетиче- 
ского порога обычных промышленных взрывов. Необходимо заметить, что энергетический класс событий «возможно взрыв» на территории Приамурья и Приморья в редких случаях превышает Кр $=8.6(M=2.6)$, что в среднем составляет менее $2 \%$ от выделившейся годовой суммарной сейсмической энергии всего региона.

Анализ записей ближайших к эпицентру взрывов станций (до 100-150 км) показывает, что, как правило, кроме продольной и поперечной волн, записывается низкоскоростная поверхностная волна, которая по амплитуде значительно превышает амплитудный размах объемных волн. На более далеких от эпицентра взрыва станциях волновая картина слабо отличается от записи корового землетрясения. При отсутствии записей близких к эпицентру взрыва станций вырастает вероятность попадания в каталог взрыва под видом естественного землетрясения.

Во многих местах проведения взрывных работ наблюдается отчетливая зависимость возникновения события от времени суток. В дневное время суток число событий возрастает многократно. Гораздо меньше событий приходится на выходные и праздничные дни. Анализ распределения взрывов и естественных землетрясений по часам суток, а также по дням недели был сделан в статье «Приморье и Приамурье» в сборнике «Землетрясения Северной Евразии в 2003 году» [Фокина и др., 2009].

Все взрывы, внесённые в ежегодный каталог землетрясений Приамурья и Приморья с пометкой «возможно взрыв», удалены из каталога, представленного в данной работе.

Тем не менее, несмотря на все усилия по распознаванию природы событий, часть взрывов присутствует в каталогах под видом естественных землетрясений. На наш взгляд решить эту проблему можно только при наличии на территории Приамурья и Приморья более плотной сети современных сейсмических станций с цифровой регистрацией.

Дополнительно необходимо отметить, что для многих оценок, связанных, например, с общим или детальным сейсмическим районированием, построением графиков повторяемости, необходим каталог землетрясений, очищенный от зависимых событий (афтершоков). Поскольку, во-первых, информация об афтершоках является важной для других задач, во-вторых, существуют различные подходы к выявлению таких событий. Публикуемый каталог землетрясений содержит афтершоки землетрясений, их выявление не производилось.

Каталог механизмов очагов землетрясений Приамурья и Приморья (Приложение 2) содержит данные о 109 землетрясениях, произошедших в период с 1963 по 2014 г. Определение параметров очага землетрясения в приближении двойного диполя осуществлялось с использованием программы «Механизм» [Аптекман и др., 1979] методом полярности первых вступлений в $P$-волне $(P g, P n, p P)$. Полученные решения, по возможности, уточнялись путем привлечения (вручную) знаков $S V, S H, S V G, S H G$-волн с использованием теоретических палеток нодальных линий для $S V$ и $S H$-волн [Балакина, 1972]. Каталог содержит дату события, координаты эпицентра, глубину (согласно Приложению 1), магнитуду М $(M L H)$, сферические координаты трех главных осей и двух нодальных плоскостей одного наиболее вероятного решения механизма очага. Указан тип сейсмодислокации в очаге согласно приводимой ниже классификации, которая используется в СФ ГС РАН в настоящее время. Приводится стереограмма механизма очага в проекции на нижнюю полусферу.

Классификация механизмов очагов землетрясений по типу сейсмодислокации осуществляется по величине наклона к горизонту оси $N$ промежуточного напряжения $(P L N)$, нодальных плоскостей $(D P)$ и сравнению угла наклона осей Р и Т:

сдвиг: $P L N \geq 45^{\circ}$; сбросо-сдвиг: $20^{\circ} \leq P L N<45^{\circ}, P L T>P L P$; взбросо-сдвиг: $20^{\circ} \leq P L N<45^{\circ}, P L P>P L T$; сброс: $P L N<20^{\circ}, D P>20^{\circ}, P L T>P L P$; взброс: $P L N<20^{\circ}, D P>20^{\circ}, P L P>P L T$; пологий сброс: $D P<20^{\circ}, P L T>P L P$; пологий надвиг: $D P<20^{\circ}, P L P>P L T$. 


\section{ГЛАВА 4}

\section{РАЗЛОМНАЯ ТЕКТОНИКА И СЕЙСМОГЕННЫЕ ЗОНЫ ПРИАМУРЬЯ И ПРИМОРЬЯ}

Регион Приамурье и Приморье включает разнообразные физико-географические ландшафты: горные массивы, плоскогорья, обрамленные обширными низменностями. На западе в его пределах замыкается рифтовая зона Забайкалья, на крайнем юго-востоке располагается современная геосинклинальная котловина Японского моря. Преобладающая часть региона относится к Монголо-Охотской складчатой области, располагающейся между протерозойской структурой Станового хребта (горная система и высокие плоскогорья) и Китайской платформой (обширные низменности и мелкосопочные равнины). Приморье и нижняя часть Приамурья находятся в пределах мезозойской складчатой области (горная страна с предгорными и межгорными прогибами). Названные тектонические области ограничены глубинными разломами и осложнены более мелкими поперечными нарушениями. Возникшая диагональная сеть разрывных линеаментов создает в регионе сложную мозаику блоков различного порядка [Леонов и др., 1977; Караулов, Ставцев, 1975].

C тектонической позиции Приамурье и Приморье расположены на Амурской литосферной плите. Положение границ и кинематика этой плиты отличается у разных авторов. Многие исследователи [Zonenshain, Savostin, 1981; Wei, Seno, 1998; Bird, 2003; Гатинский, Рундквист, 2004; DeMets et al., 2010] проводят ее северную границу вдоль Байкальского и северной ветви Станового сейсмических поясов. Другие [Шерман и др., 1984; Petit, Fournier, 2005; Имаев и др., 2003; Малышев и др., 2007] проводят границу по югу Алданского щита - Монголо-Охотской разломной зоне.

Относительно восточной границы также нет единого мнения. Согласно схемам [Зоненшайн и др., 1979; Zonenshain, Savostin, 1981], на которых Амурская плита выделена впервые, восточная граница проходит вдоль сейсмоактивных структур о. Сахалин и прослеживается далее на юг через о. Хоккайдо и вдоль восточного побережья Японских островов; авторы [Wei, Seno, 1998; Bird, 2003; Парфенов и др., 2003; Petit, Fournier, 2005, DeMets et al., 2010] также проводят эту границу вдоль разломных структур о. Сахалин далее в Японию или Японское море. Существует также позиция, согласно которой Японо-Корейский блок (территория к востоку и юго-востоку от разломов Танлу) не принадлежит Амурской плите [Гатинский, Рундквист, 2004], к такому же мнению пришли авторы работы [Ашурков и др., 2011], у которых мы позаимствовали данный обзор источников. Есть также позиция В.С. Имаева с соавторами [Имаев и др., 2003; Имаева и др., 2012], согласно которой восточная граница плиты к северу от Амура отклоняется от диагональных структур Танлу и идет меридионально на север вдоль пояса максимальной сейсмичности.

Описание разломной тектоники региона дано в соответствии с общей схемой, приведенной в работе [Тектоника..., 2004]. На рис. 4.1 показаны основные разломы региона Приамурье и Приморье, попадающие в зону ответственности СФ ГС РАН

Разломная тектоника Приамурья и Приморья отличается чрезвычайной сложностью. Ведущие тектонические нарушения региона имеют близширотную, северо-восточную и близмеридиональную ориентировку, которая согласуется с конфигурацией Алдано-Станового, Байкальского и Северо-Китайского архейских геоблоков, границами Аргунского, Буреинско-Канкайского, Суннэнь-Туранского и Южно-Гобийского композитных срединных массивов, и имеют, как правило, архейское или ранне-протерозойское заложение» [Тектоника..., 2004].

Ниже дано краткое описание наиболее крупных разломных зон [Тектоника..., 2004] с нумерацией согласно рис 4.1. 


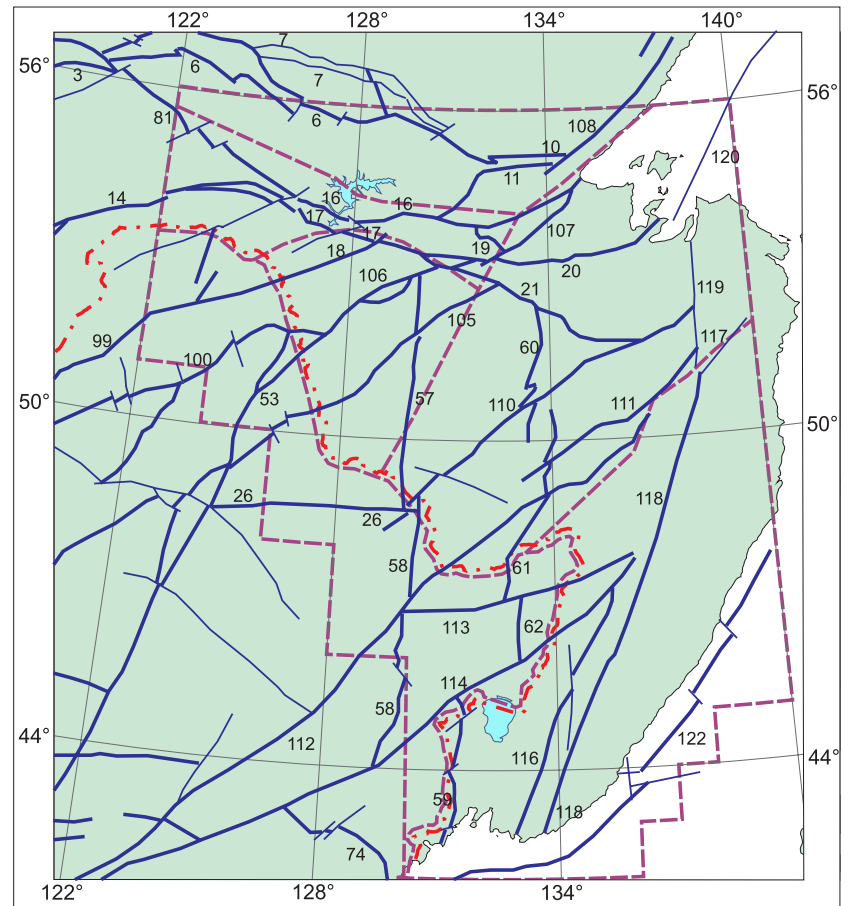

Рис. 4.1. Схема разломной тектоники Приамурья и Приморья (на основе [Тектоника..., 2004]). Нумерация разломов в тексте.

\section{ОСНОВНЫЕ РАЗЛОМНЫЕ СИСТЕМЫ И РАЗЛОМЫ РЕГИОНА:}

\section{Становая система разломов}

3. Каларский

6. Становой

7. Ытымджинско-Нуямская р.з.

10. Салга-Джанинский

11. Удыхинский

\section{Монголо-Охотская система разломов}

14. Монголо-Охотский

16. Северо-Тукурингрский

17. Южно-Тукурингрский

18. Нинни-Сагаянский

19. Ланский

20. Тугурский

21. Пауканский

\section{Система разломов Намурхэ}

26. Намурхэ

Система разломов Муданцзян

57. Западно-Туранский

58. Муданьцзянская р.з.

59. Западно-Приморский

Арсеньевско-Тастахская система разломов

61. Куканский

62. Дахэджен

Озерная-Дириун-Хуацзян система разломов

74. Хайларская р.з.

81. Джелтулакский
Ундуршили-Синлунгоу-Агунская система разломов

99. Синлунгоу

100. Р.з. Хайлар-Ульхури

Система разломов Нукутдабан-Синкайлинь

105. Селемджинский

106. Буссе-Норская р.з.

Западно-Охотская система разломов

107. Улигданский

108. Ждугджурский

Система разломов Танлу

110. Хинганский

111. Курский

112. Ишу-Харпинский

113. Наолихэ

114. Дунми

116. Западный Сихотэ-Алинский

117. Киселевский

Сихотэ-Алинская система разломов

118. Ц Центральный Сихотэ-Алинский

119. Лимурчанский

120. Toxареу

122. Прибрежный 
Становая система разломов $(3,6,7,10,11$ в пределах региона) протягивается на 1200 км от Патомско-Жуинской близмеридиональной зоны к охотскому побережью, где плавно изменяет простирание на северо-восточное (Джугджурский разлом - 108 на рис. 4.1), ограничивая Алданский щит с юга. Тектоническая активность Станового линеамента не прекращалась в кайнозое и продолжается вплоть до настоящего времени. Несмотря на интенсивное проявление молодых надвигов и шарьяжей, определенных по комплексу геолого-геофизических данных, Становой линеамент имеет крутое падение на юг, ему соответствует гравитационная ступень в подошве земной коры, линейно-вытянутые магнитные и гравиметрические аномалии.

Главные разломы Монголо-Охотской системы (14-21) являются преимущественно коллизионными и носят сдвигово-раздвиговый характер. Монголо-Охотский (14) и Северо-Тукурингрский (16) краевые глубинные разломы общей протяженностью 2700 км отделяют складчато-надвиговую систему от Становой и Селенгино-Яблоновой областей, а Ульдзинский, Восточно-Агинский, Пришилкинский (за пределами карты), Южно-Тукурингрский (17) и Нинни-Сагаянский (18) ограничивают систему с юга. Во фронтальных частях геоблоков развиты пологие надвиги и взбросы. Установленная амплитуда смещений в отдельных частях СевероТукурингрского разлома достигает нескольких десятков километров.

Муданьцзян: Муданьцзянский (58), Западно-Туранский (57) и Западно-Приморский (59) разломы на протяжении рифея, палеозоя и раннего мезозоя были граничной зоной между Буреинско-Цзямусы-Ханкайским микроконтинентом и мобильными системами Центрально-Азиатского подвижного пояса.

В систему разломов Танлу (110-117) объединены разломы северо-восточной ориентировки, расположенные в широкой полосе от Мал. Хингана на северо-западе (Хинганский разлом 110) до Ханкайского массива на юге (ЗападноСихотэ-Алинский разлом 116). Система разломов имеет протяженность более 2000 км. Основными особенностями системы Танлу являются рифтогенная природа разломов, начиная с позднего мела и до четвертичного этапа, и отчетливо проявленный сдвиговый характер перемещений по ряду нарушений. Максимальные перемещения фиксируются по разлому Дунми (114) - левосторонний сдвиг превышает 200 км. Наиболее протяженный и выдержанный Ишу-Харпинский (112) разлом отчетливо фиксируется геофизическими методами в виде зоны нарушения структуры поля силы тяжести.

Сихотэ-Алинская система разломов (118122) тесно взаимосвязана с развитием Вандашань-Сихотэ-Алинской складчато-надвиговой системы, которая рассматривается как пограничная или переходная между Амурским и Япономорским мегаблоками. Наиболее крупным разломом в системе является ЦентральноСихотэ-Алинский (118), он представляет собой левосторонний сдвиг, секущий структурно-формационные зоны Приморья, протяженность разлома более 900 км. По этому и по ряду других разломов рассматриваемой системы на этапе неотектоники происходили левосторонние сдвиговые смещения.

На рис. 3.1 показана схема деления территории Приамурья и Приморья на районы, различающиеся уровнем и характером наблюденной сейсмичности, предложенная Л.С. Оскорбиным и применяемая для анализа сейсмичности в СФ ГС РАН по настоящее время. Согласно этой схеме вся территория Приамурья и Приморья поделена на 6 районов [Коваленко и др., 2010]:

1 - Становой, включающий юго-восточную часть Становой системы разломов и связанные с ней землетрясения, при этом большая и наиболее активная часть разломной системы остается за пределами зоны ответственности СФ ГС РАН (относится к Якутскому филиалу);

2 - Янкан-Тукурингра-Джагдинский, наиболее сейсмически активный район, включающий восточный фланг Монголо-Охотской системы разломов;

3 - Зейско-Селемджинский район, включающий относительно слабо сейсмичный бассейн рек Зея и Селемджа;

4 - обширный Турано-Буреинский район, находящийся на северо-восточном фланге системы разломов Танлу;

5 - Сихотэ-Алинский район, включающий сейсмогенные зоны Сихоте-Алиня Южного Приморья и прибрежной акватории Японского моря;

6 - Приграничный район, включающий территории Китая и Монголии, граничащие с Россией в зоне ответственности СФ ГС РАН. 


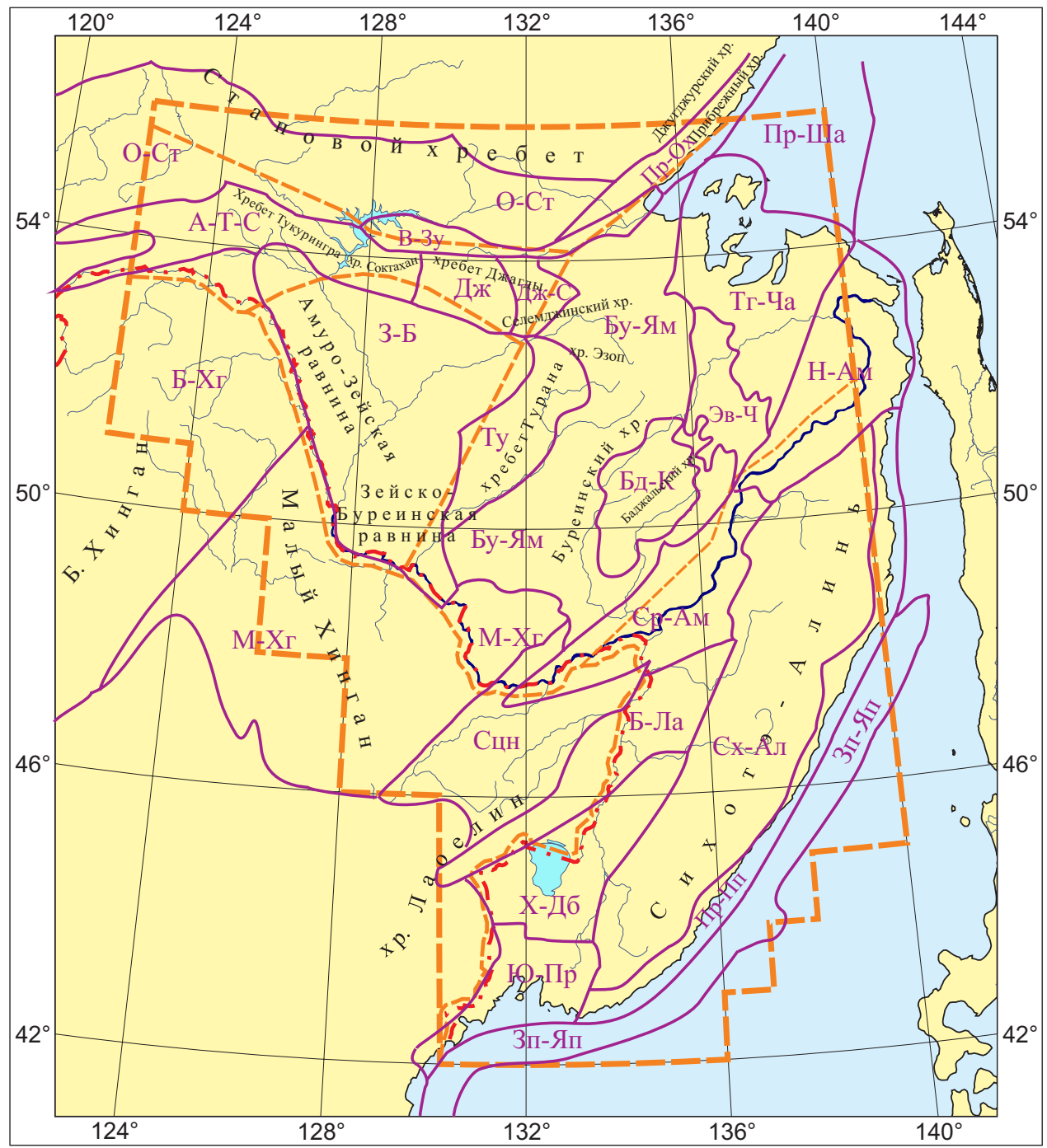

Рис. 4.2. Схема сейсмогенных зон (зон ВОЗ) территории Приамурья и Приморья по Л.С. Оскорбину [Оскорбин, 1997].

В работе [Оскорбин, 1997] приводится схема районирования территории Приамурья и Приморья по сейсмогенным зонам, выполненная на основе совместного анализа сейсмологической и геолого-геофизической информации. Ниже дано описание сейсмогенных зон, сопоставляемое с включающими их районами, актуализированное последними сейсмологическими наблюдениями.

Олекмо-Становой район (№ 1). ОлекмоСтановая (О-Ст) сейсмогенная зона. Расположена в пределах Джугджуро-Становой складчатой области Алдано-Станового геоблока. Выражена Тукурингра-Становым межгорным понижением блоком земной коры шириной от 60 до 120 км, опущенным относительно Станового (на севере) и Тукурингра-Джагдинского (на юге) поднятий. Представляет собой обширную денудаци- онно-выровненную поверхность, наклоненную к Верхнезейской впадине. В поле наблюденной сейсмичности Олекмо-Становая сейсмогенная зона характеризуется землетрясениями 1 ноября 1977 г. $(\mathrm{M}=4.8)$ и 7 августа 1986 г. $(\mathrm{M}=4.8)$.

Верхнезейско-Удская (В-Зу) сейсмогенная зона состоит из Верхнезейской впадины и Удского прогиба, которые в неогене соединились, образовав единый седиментационный бассейн [Солоненко и др., 1985], расположена на границе между разновозрастными Монголо-Охотским складчатым поясом и областью складчатости СтановикаДжугджура. Формирование Верхнезейской впадины связано с мезокайнозойским тектоническим этапом, а блоковые перемещения по разломам в фундаменте впадины не прекращаются и в настоящее время. Уровень сейсмической активности 
низкий, самое значительное событие произошло 28 января 1994 г. $(\mathrm{M}=4.7)$.

Прибрежно-Охотоморская (Пр-Ох) зона расположена в Джугджуро-Становой складчатой области [Николаев и др., 1982]. В рельефе выражена Прибрежным хребтом и юго-восточными отрогами хр. Джугджур. Наблюденная сейсмичность в пределах региона довольно слабая, самое сильное событие произошло 13 августа 1965 г. $(\mathrm{M}=4.4)$, однако на продолжении этой зоны на север известны более сильные события.

Янкан-Тукурингра-Джагдинский район (№ 2). Восточную его часть занимает АмазарскоТукурингра-Соктаханская (А-Т-С) сейсмогенная зона, в современном рельефе выраженная одноименными, Янкан и другими мелкими горными хребтами. Эта зона занимает часть протяженной и сложнопостроенной шовной Монголо-Охотской геосинклинальной складчатой системы, разграничивающей Алдано-Становой и Амурский геоблоки [Красный, 1980]. Тукурингра-СоктаханДжагдинское поднятие с северо-востока и югозапада ограничивается активизированными в кайнозое Северо-Тукурингрским и Южно-Тукурингрским глубинными разломами, которые в новейший тектонический этап развиваются как взбросо-сдвиги; эти разломы посредством диагональных, широтных и северо-восточных разрывов соединяются между собой. На севере по системе разрывных нарушений (включая Северо-Тукурингрский разлом) А-Т-С зона граничит с Алдано-Становой и В-Зу. На юго-западе по Южно-Тукурингрскому и Южно-Борщевочному разломам отделена от Больше-Хинганской зоны. Отделяется Огоронской впадиной от Джагдинской зоны на востоке. Сейсмическая активность зоны проявилась в целом ряде сильных землетрясений (см. гл. 5.4), сильнейшее из которых произошло 14 октября 2011 г. $(M=6.2)$.

Джагдинская (Дж) сейсмогенная зона в современном рельефе выражена хр. Джагды. В структурно-тектоническом плане занимает интенсивно пликативно и дизъюнктивно дислоцированный Джагдинский сегмент Амуро-Охотской складчатой системы. На востоке по локальным разломам и восточным отрогам хр. Джагды граничит с Дж-С. Сейсмичность зоны представлена слабыми событиями с магнитудой, не превышающей $\mathrm{M}=4.2$ (землетрясение 21 июля 1992 г.).

Джагдинско-Селемджинская зона (Дж-С). Представляет узел, состоящий из: в рельефе восточной части хр. Ждагды, юго-западной части Тайканского хребта и западной и центральной части Селемджинского хребта; в структурно-тектоническом плане - востока Джагдинского сег- мента, запада Селемджино-Кербинского сегмента и небольшой по размерам юго-западной части Удско-Шантарского сегмента Амуро-Охотской складчатой системы [Николаев и др., 1989]; в новейшем тектоническом плане - зоной сочленения Джагдинского глыбового поднятия, Тайканского полусвода и Ямалинского сводового поднятия. На востоке по дизъюнктивам клином отделена от Буреино-Ямалинской зоны. В сейсмическом поле максимальными наблюденными являются Селемджинские землетрясения 29 июня 1975 г. $(\mathrm{M}=5.3)$ и 30 июля 1983 г. $(\mathrm{M}=4.8)$ (см гл. 5.4).

Зейско-Селемджинский район (№ 3). Зейско-Буреинская (3-Б) сейсмогенная зона в современном рельефе входит в состав Приамурской геоморфологической провинции и представлена Амуро-Зейским аккумулятивным слаборасчлененным плато, Зейско-Буреинской террасовой равниной, Белогорской аккумулятивной равниной, Призейской цокольной равниной и др. [Воскресенский и др., 1980]; во многих местах вдоль рек из-под аккумулятивных отложений выходят скальные коренные породы в виде сопок. Проявление сейсмичности здесь, возможно, связано с процессом погружения основания таких сопок под толщи неоген-четвертичных отложений. В структурно-тектоническом плане 3-Б зона расположена полностью в Буреинском массиве [Тектоническая карта..., 1978]. Зона З-Б в целом расположена в пределах Амуро-Зейской плиты - краевой части молодой Дунбейской платформы. Развитие активизированных участков платформы находится под воздействием морфоструктур орогенного пояса, особенно это касается, по-видимому, приразломных впадин - Пиканской, Депской, Норской и др.; тем не менее, участвуя в этом процессе пассивно, они накапливают тектонические напряжения. Сейсмогенная зона З-Б граничит с зонами Б-Хг, A-T-C, Дж, Дж-С, Ту, Бу-Ям (по границе между геоструктурами) и М-Хг (по такой же границе и по разлому). Сильнейшие зарегистрированные землетрясения: 6 августа 1911 г. $(\mathrm{M}=5.0)$ и 16 января 2004 г. $(\mathrm{M}=5.0)$.

Турано-Буреинский район (№ 4). Туранская (Ту) сейсмогенная зона в современном рельефе выражена одноименным низкогорным хребтом с отрогами и западной частью хр. Эзоп. В структурно-тектоническом плане Ту зона представлена Туранским блоком Буреинского массива. Граничит с зоной 3-Б на западе и северо-западе по границе между кайнозойской плитой Дунбейской молодой платформы и эпиплатформенными орогенами; с зоной Бу-Ям на юго-востоке вдоль p. Бурея по границе между Туранским поднятием и Буреинской долиной - грабеном и Ургальной 
межгорной впадиной, на востоке - по Тастахскому разлому и на севере - по Пауканскому разлому. Сейсмичность района представлена большим числом умеренно-сильных событий, сильнейшее из которых - Огоджинское землетрясение - произошло 5 марта 1987 г. $(\mathrm{M}=5.2)$.

Буреино-Ямалинская (Бу-Ям) сейсмогенная зона в структурно-тектоническом плане включает в себя восточную половину СелемджиноКербинского сегмента, запад Ульбанского синклинория и юго-запад Удско-Шантарского сегмента Амуро-Охотской ГСС, участки Баджальского мегаантиклинория и Горинского синклинория СихотэАлинской ГСС, восточную часть Буреинского срединного массива; Буреинский массив отделен от Сихотэ-Алинской ГСС системой ступенчато смещенных глубинных разломов - Тастахским, Куканским, Улинским [Николаев и др., 1989]. Существенное значение в строении Бу-Ям зоны принадлежит разрывным нарушениям различных рангов, главнейшими из которых являются ЮжноТукурингрский и его разветвления (Пауканский, Тастахский, Тугурский), Хинганский, Курский, Куканский, Верхнеамгунский и др. Эти крупные разновозрастные разломы сформировались в процессе длительного геологического развития. Южно-Тукурингрский разлом представлен своей крайней восточной частью, служит границей между Амуро-Охотской ГСС и Буреинским массивом и на новейшем этапе развивается как взбросо-сдвиг, что может говорить о преобладании северо-восточного сжатия в становлении и развитии новейших структур. Об активности на новейшем этапе Пауканского разлома (протяженностью выше 300 км) могут свидетельствовать четкая морфологическая выраженность, излияние в его зоне эоценовых базальтов и приуроченность к Эзопскому участку зоны повышенных градиентов скоростей вертикальных движений. Границей между Буреинским массивом и Сихотэ-Алинской ГСС является Тастахский (протяженностью до 250 км и, по данным ГСЗ, проникающий до глубины 140 км) и Куканский (протяженностью более 500 км при глубине заложения до 140 км) разломы. Бу-Ям ветвь Хинганского разлома (общей протяженностью около 600 км) разделяет Туранский и Мало-Хинганский блоки. Наиболее подвижной частью Хинганского разлома является его северо-восточный (Буреино-Баджальский) отрезок. Поле эпицентров землетрясений достаточно плотно покрывает всю Бу-Ям зону (рис. 3.2), однако действительно сильных событий в ее границах не зарегистрировано, магнитуды происходящих здесь землетрясений ограничены значениями $\mathrm{M}=4.4-4.7$, как, например, событие 5 мая 1994 г. $(\mathrm{M}=4.7)$.
Баджало-Куканская (Бд-К) сейсмогенная зона в структурно-тектоническом плане расположена в Баджальском мегаантиклинории СихотэАлиньской главной складчатой системы (ГСС), складчатая структура которого сильно разбита разрывными нарушениями северо-восточного простирания, по которым происходили сдвигонадвиговые перемещения [Николаев и др., 1989]. В сейсмическом поле зона характеризуется максимальными наблюденными событиями 23 августа 1888 г. $(\mathrm{M}=5.5)$ и Баджальским землетрясением 30 августа 1970 г. $(\mathrm{M}=5.5)$.

Эворон-Чукчагирская (Эв-Ч) сейсмогенная зона расположена в Горинском синклинории Сихотэ-Алинской ГСС и Ульбанском синклинории Амуро-Охотской ГСС. Представляет собой развивающуюся неотектоническую структуру, на отдельных участках которой наблюдаются признаки молодых прогибаний [Уфимцев, 1984]. Зону Эв-Ч пересекают Пауканский и Хинганский разломы, их неотектоническая активность относительно невелика, сильнейшее зарегистрированное событие 12 января 2007 г. $(\mathrm{M}=4.7)$.

Тугуро-Чаятынская (Тг-Ча) сейсмогенная зона расположена в пределах Ульбанского синклинория и Удско-Шантарского сегмента АмуроОхотской (Монголо-Охотской) ГСС, включая парашельф с локальными поднятиями, образующими рельеф Шантарских островов [Тектоническая карта..., 1978]. В пределах зоны Тг-Ча имеется серия неотектонических взбросов и сбросов северо-восточного простирания, ее пересекает Лимурчанский разлом, являющийся ответвлением Центрально-Сихотэ-Алинского разлома, имеющий субмеридиональную направленность и определенный как левосторонний сдвиг [Бельтенев, 1982]. Значительная часть территории зоны охвачена эпицентрами землетрясений, но общий уровень сейсмичности невысокий, наиболее сильное событие произошло 30 августа 1988 г. $(\mathrm{M}=4.7)$.

Пришантарская (Пр-Ша) сейсмогенная зона занимает парашельф - подводное продолжение Монголо-Охотской складчатой системы [Тектоническая карта..., 1978]. В восточной половине пересечена двумя разломами северо-восточного направления. Уровень сейсмичности низкий, землетрясений магнитудой более $\mathrm{M}=4.0$ не зарегистрировано.

Сихотэ-Алинский район (№ 5). Нижнеамурская (Н-Ам) сейсмогенная зона занимает Тахтинский краевой массив, северо-восточные участки Горинского и Западно-Сихотэ-Алинского синклинориев и северную часть ЦентральноСихотэ-Алинского антиклинория Сихотэ-Алинской ГСС [Салун, 1978]. Между зонами Н-Ам и 
Сх-Ал, Пр-ПП граница проведена по юго-восточным отрогам хр. Хоми или по зоне неотектонического глубинного разлома северо-восточного простирания. Сильнейшее произошедшее здесь землетрясение - 23 декабря 1914 г. $(\mathrm{M}=6.0)$, другие сильные события: 11 марта 1924 г. $(\mathrm{M}=5.6)$ и 25 ноября 1924 г. $(\mathrm{M}=5.3)$.

Средне-Амурская (Сp-Ам) сейсмогенная зона занимает одноименную впадину, вытянутую в северо-восточном направлении в виде эллипса. Впадина представлена обширной низкорасположенной аккумулятивной равниной, на фоне которой местами возвышаются остаточные сопочные массивы хребтов Вандан, Горбылян, Хехцир, Халхадьян и др. В пределах зоны имеется значительное количество неотектонических взбросов и сбросов различной протяженности и ориентировки, однако генеральным простиранием структурных элементов зоны является северо-восточное, обусловленное широким развитием разрывных нарушений этого направления; важное значение имеют также северо-западные разрывы. Граница между Ср-Ам и соседними Сх-Ал и Н-Ам проведена примерно вдоль изолинии, разделяющей положительные и отрицательные амплитуды неотектонической деформации. Наблюденная сейсмичность характеризуется подземными толчками $\mathrm{M}<3.5$, а максимальным является землетрясение 25 мая 1904 г. $(\mathrm{M}=4.7)$, параметры которого определены по макросейсмическим данным [Новый каталог..., 1977].

Сихотэ-Алинская (СХ-Ал) сейсмогенная зона расположена полностью в Сихотэ-Алинской ГСС, центральное место среди структур которой занимает Главный антиклинорий Сихотэ-Алиня [Аргентов и др., 1976]. С запада он ограничен Даубихинским (Арсентьевским) разломом, с востока - Центральным Сихотэ-Алинским разломом. Сихотэ-Алинский синклинорий занимает восточную часть одноименной горной системы и ограничен с запада Центральным, а с востока Восточным Сихотэ-Алинским разломами. Синклинорий разделен глубинными разломами на западную, осевую и восточную части (в зону Сх-Ал не входит), а поперечными зонами на южную, среднюю и северную части. Крупнейшей разрывной структурой является Центральный Сихотэ-Алинский разлом, прослеживаемый на 600-700 км. Разлом определен как левосторонний сдвиг с амплитудой горизонтального перемещения на севере в 60 км [Иванов, 1972], в южной части представляет надвиговую зону шириной 3-4 км с наклоном поверхности скола под углом 70-80 к юго-западу, т.е. в сторону Сихотэ-Алинского антиклинория. Сейсмическая активность характеризуется крайне низким уровнем, слабые события регистрируются вдоль границ зоны, в том числе и наиболее значительное 7 декабря 1980 г. (M=4.7).

Прибрежная Приморско-Приамурская (ПрПП) зона включает в себя на юге прибрежный антиклинорий (восточную зону Сихотэ-Алинского синклинория), на севере - узкую прибрежную полосу Сихотэ-Алинского синклинория, а также подводные геоструктуры зоны сочленения Сихотэ-Алинской ГСС и Япономорского массива. Граница с осевой зоной Сихотэ-Алинского синклинория проходит по глубинному Прибрежному разлому, от зоны Зп-Яп отделена Восточным Сихотэ-Алинским глубинным разломом [Харахинов и др., 1984]. Прибрежный разлом представляет собой надвиг, по которому палеозойские и мезозойские образования надвинуты на меловые отложения осевой зоны синклинория. Восточный Сихотэ-Алинский разлом протягивается в северовосточном направлении вдоль континентального склона. Землетрясения здесь регистрируются довольно редко, значительный всплеск активности Ванинские землетрясения 1968 г. (М = 4.7-5.0, см. гл. 5.7).

Западно-Япономорская (Зп-Яп) сейсмогенная зона расположена в области сочленения восточной зоны Сихотэ-Алинского синклинория и глубоководной котловины Японского моря (на юго-западе) и Татарского синклинория (на северовостоке). Слабая сейсмичность регистрируется здесь плохо ввиду особенностей сети; наиболее сильные землетрясения: 10 июня 1927 г. $(\mathrm{M}=5.0)$ и Приморское землетрясение 13 ноября 1990 г. $(\mathrm{M}=6.3)$.

Бикино-Лаоелинская (Б-Ла) сейсмогенная зона включает в себя Бикинскую зону Амуро-Уссурийского синклинория Сихотэ-Алинской ГСС и узкую часть Лаоелинской складчатой области (район № 6), выраженной в рельефе хребтами Ваньдашань и северо-востоком Лаоелина. Сильнейшее известное землетрясение 23 декабря 1948 г. $(\mathrm{M}=5.2)$.

Ханкайско-Даубихинская (Х-Дб) сейсмогенная зона включает Ханкайский массив мезозойской складчатости, Даубихинскую и Алчанскую структурно-формационные зоны позднепалеозойской складчатости. В современном рельефе Ханкайский массив выражен озерно-аллювиальной равниной и занимает значительную часть Приханкайской низменности и долины р. Уссури; Даубихинская зона выражена хребтом Синим. Алчанский разлом (протяженностью 350-400 км) отделяет Ханкайский массив на северо-востоке от Бикинской зоны и на юго-западе от Лаоелинской складчатой области. Палеозой- 
ский Даубихинский (Арсентьевский) разлом разбивается Фудзино-Иманским сдвигом или Меридиональным разломом на два: первый отделяет Даубихинскую зону, а второй Алчанскую зону от Сихотэ-Алинского антиклинория. Даубихинский разлом представляет собой крутой $\left(65-75^{\circ}\right)$ левый взбросо-надвиг, причем его западное крыло оказалось перемещенным к югу и опущенным на глубину [Бурде и др., 1963]. Фудзино-Иманский (Меридиональный) сдвиг в зоне Х-Дб представлен своим северным участком, амплитуда левого сдвига по которому составляет 7-10 км. Сдвиговый характер имеют позднепалеозойские-мезозойские глубинные разломы, в частности: ЗападноСихотэ-Алинский, разделяющий Ханкайский массив и Даубихинскую зону; Дальнереченский (Иманский, Большеуссурийский); Южно-СихотэАлинский, отделяющий зону Х-Дб от зоны Ю-Пр; другие менее крупные. Максимальная наблюденная сейсмичность: Лесозаводское землетрясение 15 августа 1962 г. $(\mathrm{M}=5.0)$ и Ханкайское 15 августа 1967 г. $(\mathrm{M}=5.0)$ (см. гл. 5.7).

Южно-Приморская (Ю-Пр) сейсмогенная зона. В эту зону включены все мезозойские наложенные впадины: Суйфунская, Хасанская из Западно-Приморской зоны; Супутинская Муравьевского антиклинория, Сучано-Даданьшанская, Дунайско-Сучанская и Сучано-Судзухинского антиклинория из Южно-Приморской зоны, включая шельф, прилегающий к этим зонам. В качестве максимальных наблюденных могут быть приняты Партизанское (Сучанское) землетрясение 19 сентября 1933 г. $(\mathrm{M}=4.5)$ и Приморское 14 сентября 1955 г. $(\mathrm{M}=4.4)$.

Приграничный район (№ 6). Саньцзянская (Сцн) сейсмогенная зона относится к Лаоелинской складчатой области. В современном рельефе представлена Санцзянской (Амуро-Сун- гарийской) равниной и северо-западными отрогами хребтов Лаоелин и Ваньдашань. Саньцзянская равнина расположена на месте тектонического прогиба, заполненного речными отложениями; над ее плоской сильно заболоченной поверхностью возвышаются островные кряжи высотой до 625 м. Самое сильное событие в этой зоне произошло 19 ноября 2013 г. (M = 4.9), также формально к этой зоне относится событие 30 января 1918 г. $(\mathrm{M}=5.0)$, эпицентр которого в районе левобережного Малого Хингана на границе с М-Хг определен по макросейсмическим данным.

Мало-Хинганская (М-Хг) сейсмогенная зона выражена в рельефе хребтом Малый Хинган с отрогами, Помпеевским, Сутарским и Щуки-Поктой хребтами. В структурно-тектоническом плане М-Хг расположена в пределах восточной части Буреинского массива или Хингано-Буреинского выступа. Сейсмическая активность этой зоны относительно высокая, представлена большим количеством сильных событий, среди наиболее сильных в пределах региона можно выделить землетрясения 17 сентября 1931 г. $(\mathrm{M}=5.5), 21$ июня 1963 г. $(\mathrm{M}=5.5)$ и серию событий 1986 г. $(\mathrm{M}=$ 4.9-5.7).

Больше-Хинганская (Б-Хг) сейсмогенная зона в современном рельефе выражена хребтом Большой Хинган с многочисленными отрогами, включая на северо-востоке Верхне-Амурский прогиб. Разломная тектоника зоны Б-Хг представлена значительным количеством неотектонических разрывных нарушений разной протяженности и, в основном, северо-восточного простирания. Уровень сейсмической активности здесь довольно умеренный, наиболее сильные события магнитудой $\mathrm{M} \sim 5$ регистрировались в южной части зоны за пределами изучаемого региона. 


\section{ГЛАВА 5}

\section{СЕЙСМИЧНОСТЬ ПРИАМУРЬЯ И ПРИМОРЬЯ}

В первую очередь, землетрясения, происходящие на территории региона Приамурье и Приморье, необходимо разделить по глубине: на коровую сейсмичность (до 50 км, рис. 3.3) и мантийную, глубокофокусную (от 100 км и ниже, рис. 5.1). Следует упомянуть, что в интервале глубин 50-100 км очагов землетрясений в рассматриваемом регионе не зарегистрировано.

\section{1. ГЛУБОКОФОКУСНЫЕ ЗЕМЛЕТРЯСЕНИЯ}

Глубокофокусные землетрясения рассматриваемой территории относятся к сейсмофокальным зонам на границе Тихий океан - континент, продолжающимся в направлении Приморья. Югозападный фланг Курило-Камчатской сейсмофокальной зоны, падающей под углом, близким к $52^{\circ}$ в сторону континента, выполаживается до $37^{\circ}$, вытягиваясь таким образом под территорию южного Приморья [Тараканов и др., 1997]. Встык с ней под территорией Японии и Японского моря проходит глубокая часть Идзу-Бонинской сейсмофокальной зоны [Zhao et al., 1994]. Таким образом, под Японским морем и Приморьем сосредоточено большое число очагов сильных глубокофокусных землетрясений, но вместе с тем лишь сильнейшие из них способны оказывать макросейсмическое воздействие на поверхность.

По энергетическому уровню глубокофокусные землетрясения значительно (на 2 порядка) превосходят коровые события региона, они относятся к принципиально отличным сейсмогенным 30нам, поэтому их следует рассматривать отдельно.

Макросейсмические проявления глубокофокусных землетрясений с эпицентрами под территорией Приморья, как правило, отсутствуют либо незначительные. Наибольший зарегистрированный макросейсмический эффект вызвало событие 8 апреля 1999 г.

8 апреля 1999 г. глубокофокусное землетрясение $(\boldsymbol{M}=7.6, \boldsymbol{M S H}=7.4 ; \boldsymbol{h}=\mathbf{5 7 2} \pm 17 \boldsymbol{\kappa M}) \mathrm{c}$ эпицентром на территории Китая в 138 км восточнее г. Владивостока вызвало ощутимые сотрясения на значительной территории.

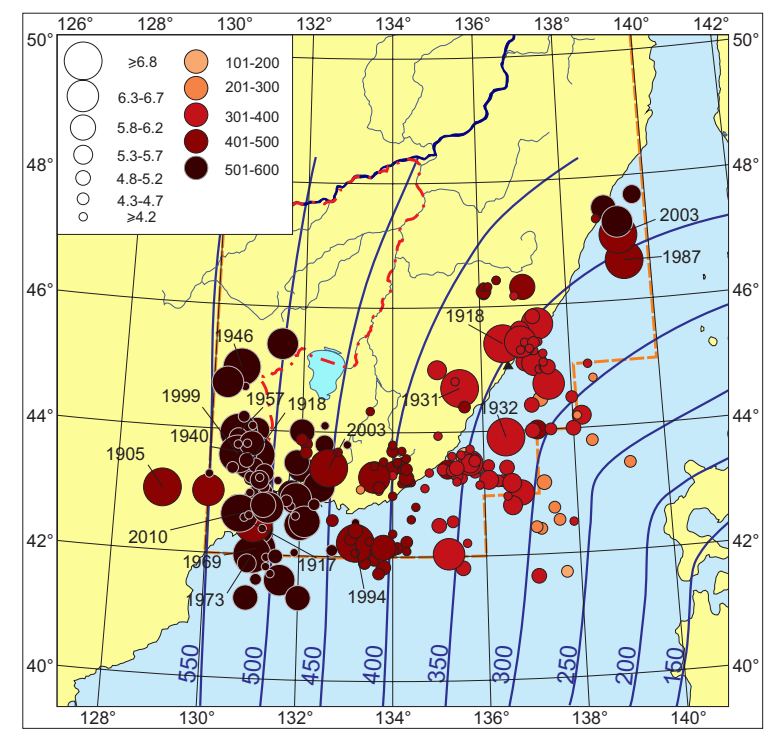

Рис. 5.1. Глубокофокусные землетрясения с эпицентрами на территории Приморья. Показаны изолинии глубин сейсмофокальной зоны согласно [Zhao, Hasegawa, 1993]. Указан год наиболее сильных событий.

Проведенное макросейсмическое обследование показало, что землетрясение ощущали практически во всех населенных пунктах Приморья, а также далеко за его пределами. Сотрясения в 2 балла отмечались в городах Благовещенск $(\Delta=770$ км), Южно-Сахалинск $(\Delta=1005$ км) и Николаевск-на-Амуре ( $\Delta=1260$ км). Наиболее сильные сотрясения - до 4 баллов - были зарегистрированы на юге Приморья - в г. Артем ( $\Delta=143$ км), Спасск-Дальний $(\Delta=185$ км), Арсеньев $(\Delta=212$ км), Лесозаводск $(\Delta=271$ км $)$, Лучегорск $(\Delta=398$ км). Согласно полученному решению механизма, в очаге землетрясения преобладали напряжения сжатия, ориентированные субгоризонтально в широтном направлении, при этом нодальная плоскость западного падения крутая, а восточного - пологая [Фокина и др., 2005].

28 июня 2002 г. глубокофокусное землетрясение $(\boldsymbol{M P V} \boldsymbol{A}=\mathbf{7 . 4} ; \boldsymbol{h}=\mathbf{5 7 1} \pm \mathbf{9} \boldsymbol{\kappa} \boldsymbol{M})$ с эпицентром на территории Китая в 110 км северо-восточнее 
г. Владивостока вызвало ощутимые сотрясения в южной части Приморья. В пос. Славянка $(\Delta=105$ км) сила сотрясений оценивается в $2-3$ балла, в других населенных пунктах, включая г. Уссурийск $(\Delta=90$ км), Владивосток, Артем $(\Delta=125$ км), Спасск-Дальний $(\Delta=180$ км), Арсентьев $(\Delta=197$ км $)$, интенсивность оценивается в 2 балла. Тип сейсмодислокации в очаге землетрясения - взброс со сдвиговой компонентой, нодальная плоскость северо-северо-восточного простирания субвертикальна, вторая полого падает на север [Фокина и др., 2008].

Землетрясение 27 июля 2003 г. ( $\boldsymbol{M S H}=7.3, \boldsymbol{h}=476 \pm \boldsymbol{\delta} \boldsymbol{\kappa})$ с эпицентром в Татарском проливе восточнее пос. Единка на севере Приморья ощутили жители южной части о. Сахалин. В г. Невельск ( $\Delta=201$ км), Анива $(\Delta=249$ км), пос. Луговое $(\Delta=260$ км) и г. Южно-Сахалинск ( $\Delta=264$ км) интенсивность сотрясений составила 2 балла. Сейсмодислокация события классифицируется как взбросо-сдвиг, одна из плоскостей механизма очага падает на запад, другая более полого - на юго-восток [Фокина и др., 2009].

\section{2. КОРОВЫЕ ЗЕМЛЕТРЯСЕНИЯ. ОБЩАЯ ХАРАКТЕРИСТИКА}

Одним из основных показателей сейсмичности территории является повторяемость землетрясений (закон Гуттенберга-Рихтера). Поскольку в рамках данной работы нет необходимости изучать изменение параметров графика повторяемости во времени или сравнивать значения его наклона для разных районов изучаемой территории (такие сравнения можно посмотреть, например, в работе [Оскорбин, Бобков, 1997б]), для построения графика был выбран достаточно длительный период каталога с относительно стабильными условиями регистрации. Полученный коэффициент наклона графика повторяемости будет принят для всего региона и периода изучения.

График повторяемости территории Приамурья и Приморья построен по данным каталога коровых (глубина до 50 км) землетрясений региона, произошедших с сентября 1982 г. по декабрь 2015 г., т.е. за период, когда представительная регистрация землетрясений на большей и наиболее сейсмоактивной части территории относительно стабилизировалась. Интервальный график повторяемости построен с шагом в 0.5 единиц магнитуды. Указанное значение соответствует центру интервала, т.е. значение $\mathrm{M}=4.0$ интервалу 3.8-4.2 и т.п. Как видно из рис. 5.2, прямолинейный характер график повторяемости приобретает со значения представительной магнитуды $M_{\text {п }}=2.5$. Нормировка на площадь территории и время не проводилась, потому практическую ценность имеет только коэффициент $b$ наклона графика.

Регрессионная прямая построена по данным в диапазоне магнитуд $\mathrm{M}=2.3-6.2$. Полученная зависимость имеет вид:

$$
\begin{aligned}
& \operatorname{Lg} N=5.59 \pm 0.11-0.88 \pm 0.03 \mathrm{M} \\
& b=0.88 ; \sigma(\lg N)=0.084 ; \mathrm{R}^{2}=0.995
\end{aligned}
$$

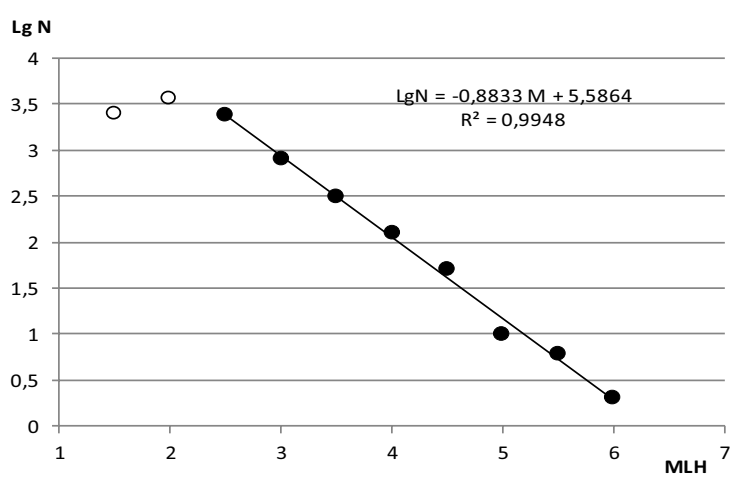

Рис. 5.2. График повторяемости землетрясений Приамурья и Приморья.

Для дальнейших расчетов имеет смысл оценить наклон графика повторяемости землетрясений с энергетической характеристикой класса Раутиан $N(K p)$. Пользуясь переходным соотношением (1), получаем коэффициент наклона графика повторяемости для энергетического класса $\gamma=0.49 \pm 0.06$. Полученное значение хорошо согласуется со значениями для соседних континентальных регионов России, например области Байкальского рифта $\gamma=0.48$, Магаданской области $\gamma=0.48$, Якутии $\gamma=0.45$ [Сейсмическое районирование..., 1978]. Коэффициент наклона графика повторяемости для энергетического класса несколько меньше полученных более ранних оценок для этой территории, например $\gamma=0.51$ [Оскорбин, 1977], $b=0.995$ [Оскорбин, Бобков, 1997б], что соответствует $\gamma=0.55$.

Количественно уровень сейсмичности Приамурья и Приморья можно оценить по карте сейсмической активности территории для уровня $\mathrm{A}_{10}$ (рис 5.3), построенной методом суммирования с постоянной детальностью [Ризниченко, 1964] :

$$
A_{10}=\frac{1-10^{-\gamma}}{10^{-\gamma\left(K_{\min }-10\right)}} * \frac{S_{0} T_{0}}{S T} * N_{\Sigma},
$$

где $\mathrm{A}_{10}$ - число очагов землетрясений в заданном диапазоне энергетического класса, в данном случае $\mathrm{Kp}=10 \pm 0.5$, происходящих на данной территории в единицу времени $T_{0}$ (обычно 1 год), нормированное на площадь $S_{0}$, традиционно принимаемую в 1000 км² $^{2} K_{\min }-$ минимальный уровень представительной регистрации для данной территории; $S$ - площадь площадки усреднения, 
принятая в $0.3^{\circ}$ широты на $0.6^{\circ}$ долготы; $T$ - период времени, охватываемый задействованным каталогом землетрясений; $\gamma$ - угол наклона графика повторяемости землетрясений исследуемой территории; $N_{\Sigma}-$ количество всех событий представительного класса $\mathrm{Kp} \geq \mathrm{K}_{\min }$ на площадке усреднения $S$ за время $T$. В связи с небольшим количеством событий представительного диапазона на территории Приамурья и Приморья параметр $\mathrm{A}_{10}$ рассчитывался скользящим окном площадью $S$ с шагом $0.1^{\circ}$ по широте и $0.2^{\circ}$ по долготе.

Наиболее сложный вопрос для оценки сейсмической активности по предложенной формуле оказался в выборе уровня представительности, как показано в гл. 2, он значительно изменяется в течение времени и по площади изучаемой тер- ритории. По этой причине расчет сейсмической активности несколько усложнен, ее оценка выполнена на временных интервалах с различным $\mathrm{K}_{\min }$ i и затем осреднена для всего периода $T$ :

$$
A_{10}=\sum_{i} \frac{1-10^{-\gamma}}{10^{-\gamma\left(K_{\min i}-10\right)}} * \frac{S_{0} T_{0}}{S T} * N_{i},
$$

где $N_{\text {i }}$ - количество событий представительного класса Кр $\geq \kappa_{\min }$ і на площадке усреднения $S$ на интервале времени с уровнем представительности $\mathrm{K}_{\min }$ i. Для построения карты был использован каталог с 1975 по 2015 г., поскольку для этого временного периода есть оценки площадного распределения представительности каталога для всей территории региона.

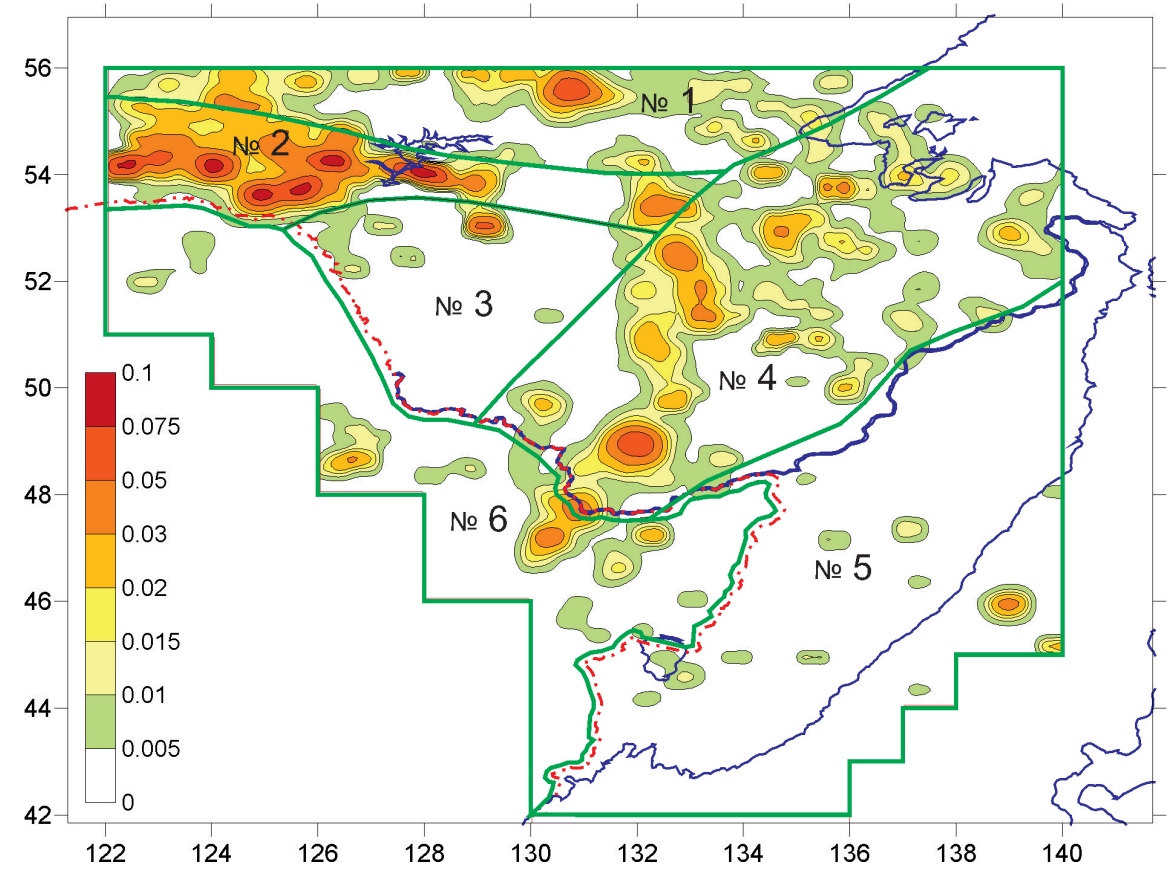

Рис. 5.3. Сейсмическая активность Приамурья и Приморья по данным каталога землетрясений 1975-2015 гг. Изолинии оконтуривают области, где ежегодное количество землетрясений энергетического класса Кр = 10 из расчета

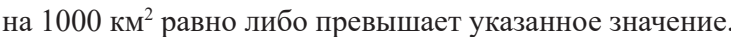

Как видно из рис 5.3, общий уровень сейсмической активности для всей территории Приамурья и Приморья не превышает значения 0.1, т.е. его можно охарактеризовать как низкий или умеренный. Наиболее высокие значения $\mathrm{A}_{10}=0.75-0.1$ получены для западной и центральной части Янкан-Тукурингра-Джагдинского района (сейсмогенная зона А-Т-С по Л.С. Оскорбину), причем восточная часть района, соответствующая хребту Джагды (Дж), напротив, полностью асейсмична в данный период, несмотря на продолжающуюся через нее Монголо-Охотскую шовную зону. P.М. Семенов и В.В. Николаев считают, что сейс- мический потенциал хр. Джагды может быть даже выше, чем у Янкан-Тукурингра-Соктаханского участка Монголо-Охотской разломной зоны, но в настоящий момент эта территория, проявлявшая себя в прошлом в виде сильных землетрясений, находится в фазе сейсмического затишья [Семенов, Николаев, 1991; Семенов, 1993].

На севере района исследований пик сейсмической активности связан с юго-восточным флангом Становой разломной зоны (О-Ст), которая, однако, переходит в довольно слабо сейсмически активную полосу в направлении Охотского побережья. 
Полоса повышенной активности со значениями $\mathrm{A}_{10}=0.2-0.75$ протягивается из правобережного Малого Хинрана (Приграничный район) через Турано-Буреинский район в сторону Олекмо-Становой сейсмогенной зоны, этот пояс повышенной сейсмической активности также выделяется в поле эпицентров повышенной плотностью зарегистрированных событий (рис. 3.2). Уровень сейсмической активности оставшейся части района № 4 можно оценить как умеренно-слабый, хотя и фрагментарно. В то время как большая часть районов № 3 , № 5 и № 6 по данным о сейсмической активности за 1975-2015 гг. почти асейсмична.

Полученные значения можно сравнить с более ранними оценками сейсмической активности для Тукурингра-Джагдинского поднятия [Семенов, Николаев, 1977; Николаев и др., 1979] и Олекмо-Становой зоны (ее южная часть) [Парфенов и др., 1985]. Появилось несколько новых максимумов активности, связанных с районами сейсмической активизации, произошедшей за разделяющие оценки десятилетия. Однако положение старых максимумов сейсмической активности и ее величина совпадают с хорошей точностью.

На рис. 5.4 показано общее количество зарегистрированных землетрясений территории Приамурья и Приморья согласно данным каталога в сравнении с суммарным уровнем сейсмической энергии, пересчитанной из магнитудных оценок по формуле [Гутенберг, Рихтер, 1961]:

$$
\operatorname{Lg} E=4.8+1.5 \mathrm{M} \text {, Дж, }
$$

где $E$ - оценка сейсмической энергии, сгенерированной очагом землетрясения, $M$ - магнитуда.
Как и следовало ожидать, суммарная сейсмическая энергия определяется наиболее сильными событиями региона, а поэтому слабо зависит от условий представительной регистрации, хотя пропуски отдельных умеренно-сильных землетрясений все же довольно существенно искажают общую картину сейсмичности, особенно в менее активных районах.

Распределение сейсмичности по территории региона можно представить в виде карты плотности сейсмической энергии либо условной упругой деформации. При этом можно использовать все землетрясения каталога, в том числе непредставительную его часть.

Идея оценки накопления условной деформации была предложена Беньофом [Benioff, 1951] с целью установления связи между энергией отдельных землетрясений и возникающими в результате этих землетрясений деформациями:

$$
e=\frac{\sum \sqrt{E}}{T},
$$

где $e$ - условная деформация, $T$ - время; $E$ - сейсмическая энергия отдельного события, произошедшего на территории $S$ в течение года, оцененная по формуле (8). Согласно, например, [Сейсмическое районирование..., 1980], полученное ежегодное значение $e$ следует нормировать также на площадь территории $S$, однако, в связи с некоторой неопределенностью этой величины (см. гл. 3), данный этап был пропущен.

Так, например, сильнейшее землетрясение каталога 3 июля 1902 г. $(\mathrm{M}=6.6)$, создавшее крупную «ступеньку» на графике (рис. 5.5), формально не входит в современные границы региона.

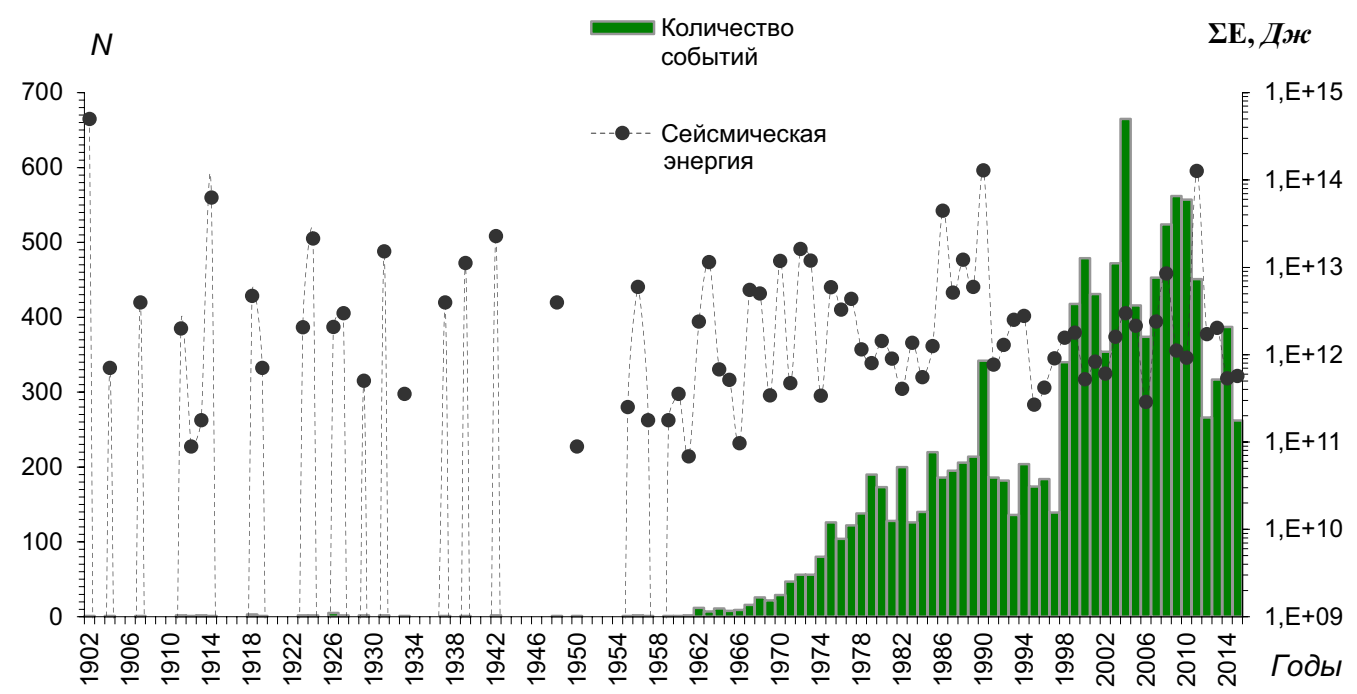

Рис. 5.4. График количества ежегодно зарегистрированных землетрясений и их суммарная сейсмическая энергия для региона Приамурье и Приморье. 


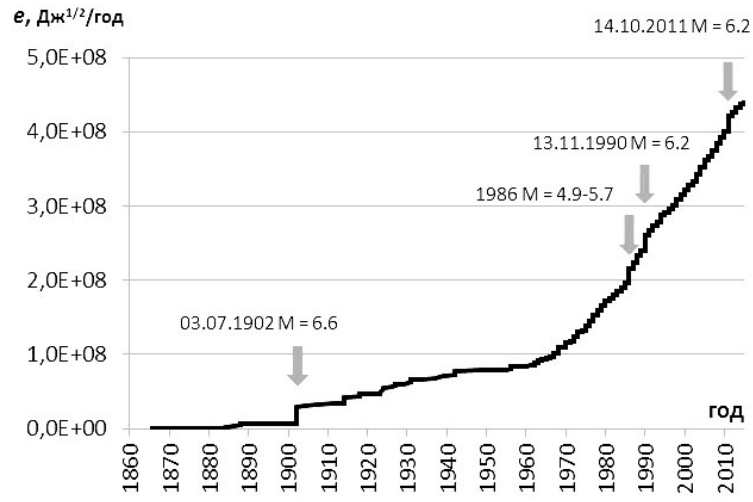

Рис. 5.5. График Беньофа для региона Приамурье и Приморье.

Как видно из рис. 5.5, на временном интервале до 1970 г. наблюдается серьезная недооценка накопления условной деформации, что связано с низкой представительностью каталога и вероятным пропуском даже довольно сильных землетрясений. После 1970 г., в связи с повышением регистрационных возможностей сети сейсмических станций, наклон графика стабилизируется, ежегодное приращение величины $e$ становится довольно равномерным, выделяются лишь пики, связанные с сильнейшими землетрясениями региона. Наиболее крупные события - это упомянутое выше землетрясение в районе хребта Лаоелин на территории Китая 3 июля 1902 г., Сковородинское землетрясение в Верхнем Приамурье 14 октября 2011 г. $(M=6.2)$, землетрясение в Татарском проливе у берегов Приморья 13 ноября 1990 г. $(M=$ 6.2), и серия сильных событий в горах Малого Хингана в феврале-августе 1986 г. $(M=4.9-5.7)$.
Также была построена карта распределения условной деформации по площади территории. При этом использовались все землетрясения каталога без учета его представительности (рис. 5.6). Потому целесообразно сопоставлять относительные величины $\omega$, что позволяет качественно оценить сейсмичность даже тех участков территории Приамурья и Приморья, для которых на карте сейсмической активности (рис. 5.3) не удалось получить оценок. Плотность условной деформации рассчитывалась по формуле:

$$
\omega=\frac{\sum \sqrt{E} * 1000}{S}
$$

где $S$ - площадь площадки усреднения, принятая в $0.3^{\circ}$ широты на $0.6^{\circ}$ долготы, аналогично расчету

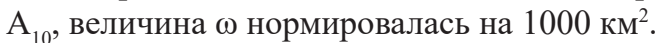

Из сравнения рис. 5.6 с картой сейсмической активности (рис. 5.3) очевидно, что области максимумов условной деформации хорошо соотносятся с пиками сейсмической активности (как и с положением эпицентров сильнейших землетрясений, рис. 3.3). Однако удалось дополнительно проследить слабую сейсмичность Турано-Буреинского, Сихотэ-Алинского и Приграничного районов, которые, согласно рис. 5.3, казались практически асейсмичными. Также замкнулась полоса повышенной сейсмичности Малый Хинган - Становой хребет, благодаря более ранним сильным событиям. Удалось зарегистрировать более высокий уровень сейсмичности Южного Приморья, где, как будет показано ниже, в середине XX в. наблюдались достаточно сильные, особенно в макросейсмическом отношении, землетрясения.

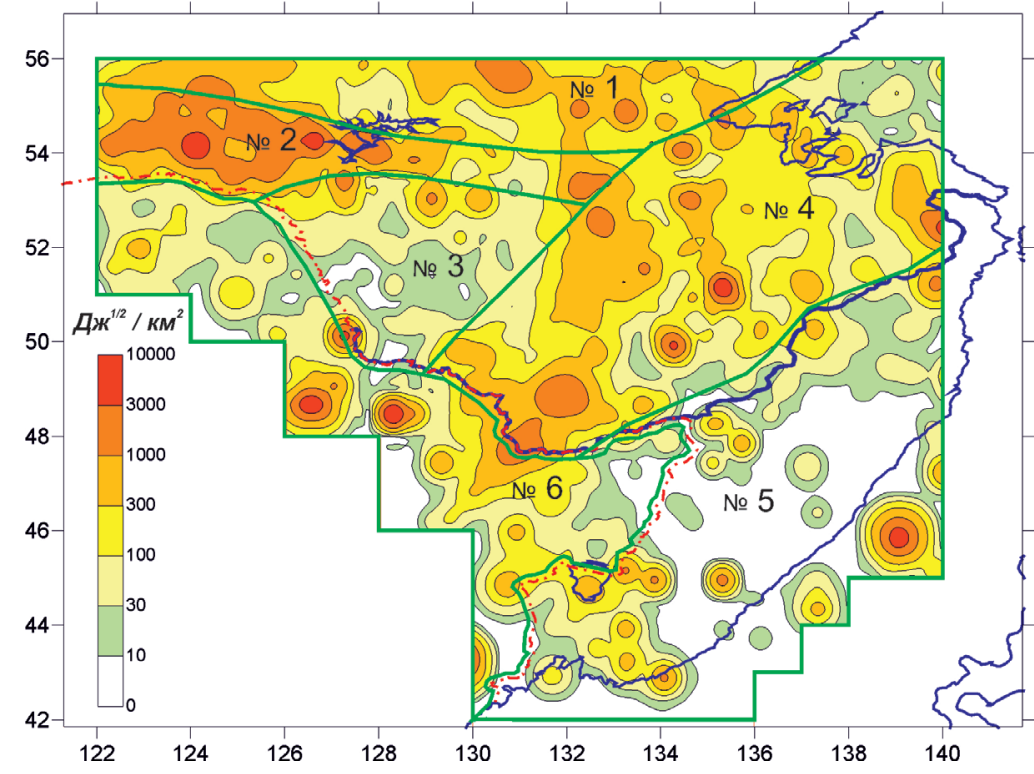

Рис. 5.6. Плотность условной деформации известных землетрясений Приамурья и Приморья в период 1865-2015 гг. 
Хотя в настоящее время в связи с развитием инструментальных наблюдений, в том числе за сильными движениями грунта, определение параметров землетрясений по макросейсмическим данным не применяется, тем не менее, традиционная оценка сейсмической опасности в баллах интенсивности сотрясений по-прежнему производится. Это делает вопрос о наблюденной интенсивности сотрясений в баллах макросейсмической шкалы актуальным. На рис. 5.7 показана карта огибающих наблюденных и расчетных изосейст землетрясений Приамурья и Приморья, a также максимальная наблюденная интенсив- ность в населенных пунктах. Карта, изначально полученная и опубликованная в статье [Оскорбин, Бобков, 1997а], была дополнена событиями последних двух десятилетий. Классификация интенсивности дана по макросейсмической шкале MSK-64. Расчет радиусов теоретических изосейст производился по уравнению макросейсмического поля [Новый каталог..., 1977]:

$$
\left.I_{i} \text { (балл }\right)=1.5 M-3.5 \lg \sqrt{\Delta_{i}^{2}+h^{2}}+3.0,
$$

где $I_{\mathrm{i}}$ - интенсивность сотрясений на расстоянии $\Delta_{\mathrm{i}} ; h$ - глубина очага.

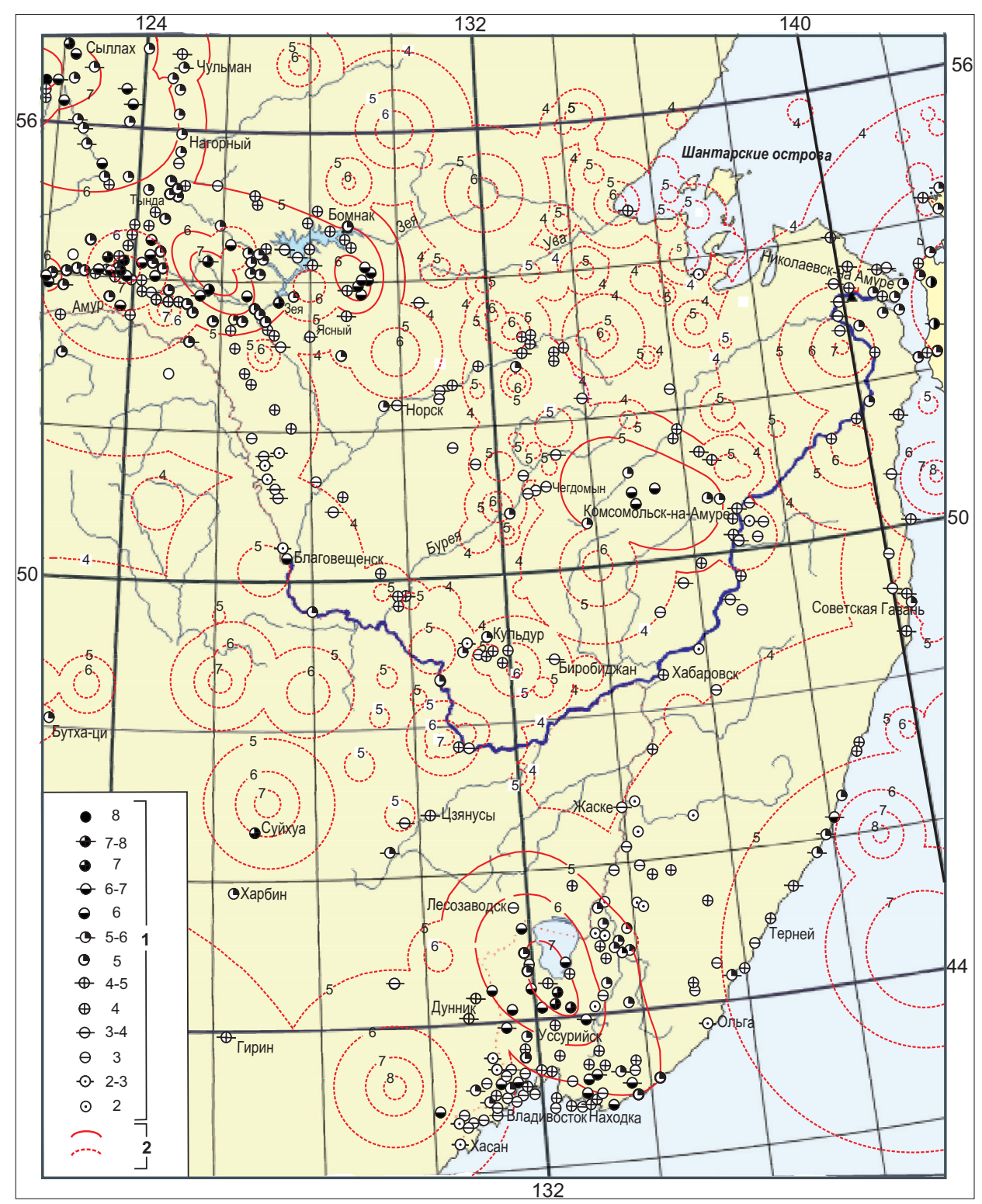

Рис. 5.7. Карта огибающих наблюденных и расчетных изосейст землетрясений и максимальной наблюденной интенсивности сотрясений в населенных пунктах Приамурья и Приморья. Построена Л.С. Оскорбиным, А.О. Бобковым [1997а], дополнена авторами. 1 - максимальная наблюденная интенсивность сотрясений в населенных пунктах; 2 - изосейсты максимальных сотрясений: наблюденные и расчетные (круговые). 
Согласно рис. 5.7, в изучаемом регионе сотрясения интенсивностью, превышающей 8 баллов, не наблюдались. 8-балльные сотрясения в населенных пунктах также не отмечены, хотя в эпицентральной зоне Сковородинского землетрясения 2011 г. $(M=6.2)$ были найдены сейсмогеологические признаки сотрясений, соответствующие 8-балльной интенсивности [Овсюченко и др., 2012].

Интенсивность сотрясений в 7 (7-8) баллов наблюдалась в ближайших к очагу населенных пунктах при упомянутом Сковородинском землетрясении, при землетрясении на Зейской пристани 1889 г. (M оценивается в 4.2) и 1911 г. (M оценивается в 5.0 ); при Зейском землетрясении 1973 г. $(M=5.5)$ и самом крупном на территории Приморья Ханкайском землетрясении 1967 г. $(M=5.0)$. В последнем случае изосейста в 7 баллов охватила область примерно в 5000 км² $^{2}$. Кроме того в 7 баллов оценивается максимальная зарегистрированная интенсивность сотрясений при Партизанском землетрясении 1933 г. $(M=4.5)$ в Приморье, слабом мелкофокусном землетрясении 1962 г. в том же районе $(M=2.7 ; h=1-2.5$ км), Приморском землетрясении 1955 г. $(M=4.4)$.

Некоторые другие сильные землетрясения теоретически были способны вызвать сотрясения в 7 баллов, однако произошли в море, малонаселенном районе, либо данные не были получены.

Как видно из приведенных данных, наиболее сильные сотрясения в регионе зафиксированы в наиболее сейсмически активном Янкан-Тукурингра-Джагдинском районе (зона А-Т-С) и на юге относительно мало активного Сихотэ-Алинского района (зоны Х-Дб и Ю-Пр), что может быть связано с его более плотной заселенностью, меньшей глубиной очага слабых событий, локальными особенностями территории, либо, наиболее вероятно, сочетанием этих факторов.

Самый низкий уровень расчетной интенсивности на территории Хабаровского края в среднем течении Амура и в центральной части Амурской области, где, согласно изолиниям рис. 5.7, сотрясения не должны были превышать 3 баллов, в реальности даже на этой территории в населенных пунктах (например, в г. Хабаровск) зафиксированы случаи сотрясений, превышающих расчетные. Как показывает детальное изучение макросейсмических проявлений сильных землетрясений Приамурья, Якутии и Байкальского региона, макросейсмическое поле таких событий крайне неоднородно, разница в интенсивности сотрясений в населенных пунктах на одной эпицен- тральной дистанции может достигать трех баллов. [Николаев и др., 1996, Ханчук и др., 2012].

\section{3. СТАНОВОЙ РАЙОН (№ 1)}

От Байкала до Охотского моря прослеживается крупная буферная сейсмотектоническая зона, являющаяся диффузной границей между Евразиатской и Амурской тектоническими плитами. Эта зона разграничена крупными тектоническими структурами (Байкальски рифт и ОлекмоСтановая зона, составляющие Байкало-Становой сейсмический пояс, а также Монголо-Охотская сутура и ее продолжение в Приамурье - Тукурингра-Джагдинская зона) на два блока - Забайкальский на западе и Алдано-Становой на востоке [Имаева и др., 2012]. В зону ответственности СФ ГС РАН входит юго-восточная часть ОлекмоСтановой зоны и большая часть собственно Алдано-Станового блока, который вместе с его северной границей выделен в поле сейсмичности в Становой район (№ 1). Наиболее значительная сейсмическая активность в этом районе связана непосредственно с юго-восточным флангом Станового разлома (6), где параметр $A_{10}$ достигает значений 0.5-0.75. Здесь же зарегистрированы наиболее сильные землетрясения. С учетом более ранних событий (землетрясения 1939 г., рис. 5.6, $5.8)$ пояс повышенной сейсмичности протягивается на восток к побережью, а также стыкуется с сейсмоактивными структурами на юге. На западе района вдоль границы с районом № 2 также прослеживается область повышенной сейсмичности, связанная с землетрясениями умеренной силы, возможно, происходящими на секущих разрывах между Становым и Джелтулакским разломами (как, например, Ларбинское землетрясение 1971 г.). Центральная часть района (собственно Алдано-Становой блок) также не является полностью асейсмичной, хотя на общем фоне менее сейсмоактивна, сильных землетрясений здесь не регистрировалось.

Данные о первых сильных землетрясениях приводятся в работе [Даммер, 1971]: «... в приосевой зоне этого поднятия имеются два очага землетрясений. Они залегают в земной коре и относятся к метаморфическому комплексу протерозойского фундамента. Один из них, очаг землетрясения 24 января 1937 2. ( $M=5.2, h=16 \mathrm{kM})$, по-видимому, тяготеет к зоне главных, широтного простирания, тектонических разломов древнего заложения. Второй очаг землетрясения 22 января 1939 2. $(M=5.5, h=20$ кM) расположен на площади новейших разрывных нарушений». 


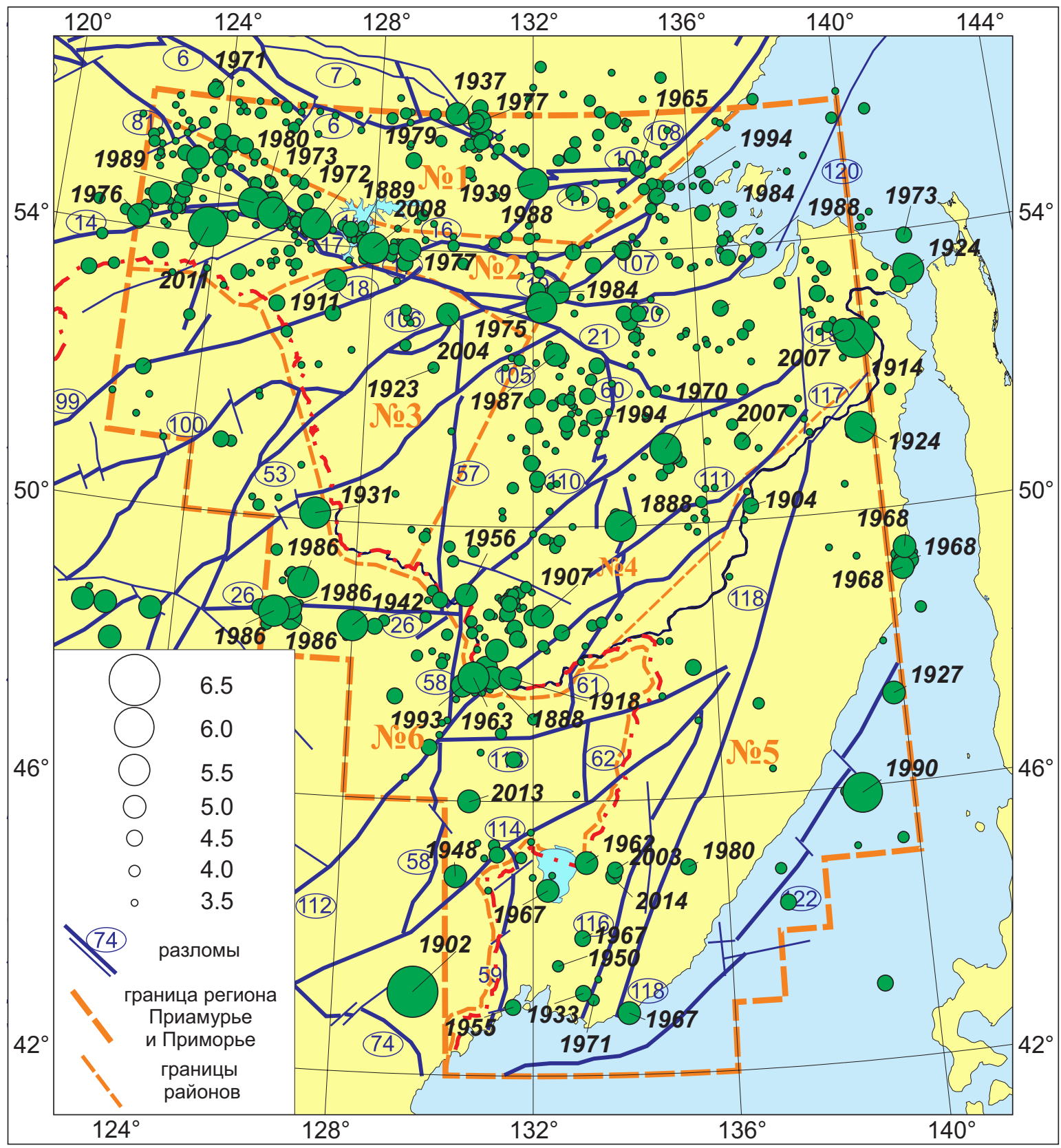

Рис. 5.8. Землетрясения Приамурья и Приморья 1865-2015 гг., $\mathrm{M} \geq 3.3$. Показана схема разломов согласно [Тектоника..., 2004], нумерация приведена в гл. 4. Указан год землетрясений, упомянутых в тексте.

Ларбинское (Зверевское) землетрясение 14 июня 1971 2. $(M=4.3, K p=12, h=10 \kappa M)$. Эпицентр его находился в верховьях р. Ниж. Ларбы - правый приток р. Нюкжа. Землетрясение приурочено к Становому структурному шву и обусловлено его современной тектонической активностью (западная часть Станового района). Землетрясение ощущалось на площади порядка 100000 км² $^{2}$ но, поскольку эпицентр располагался вдали от населенных пунктов, собранные ма- кросейсмические сведения о нем отрывочны и немногочисленны [Козьмин и др. 1975]. Геологи полевой геологической партии, бывшие на р. Ларбе, слышали мощный глухой гул, напоминающий громовые раскаты, и ощущали сильное колебание земли. Сотрясения силой 5 баллов отмечались в поселках Чульман, Беркакит, Золотинка, Нагорный, Лапри, Сигикта, Тында, Кабактан, удаленных от эпицентра на расстояние до 150 км [Coлоненко и др., 1985]. 
По данным инструментальных наблюдений за 1962-2015 гг. наиболее сейсмически активным участком в Становом районе остается продолжение на его территорию Станового разлома, к зоне которого отнесены два вышеупомянутых землетрясения 1937 и 1939 гг. На этом же участке произошли два сильнейших землетрясения района за последующий период времени - Джугдырское 1 ноября 1977 2. $(M=4.8, h=20-30$ км) и Токинское 27 апреля 1979 г. $(M=4.3, h=30$ км). Эти землетрясения имели схожие механизмы очага, произошли в условиях субгоризонтального сжатия северного направления. Однако в очаге события 1977 г. растягивающие напряжения ближе к горизонту, потому землетрясение можно классифицировать как сдвиг, левосторонний вдоль вертикальной плоскости северо-восточного простирания, либо правосторонний вдоль плоскости юго-восточного простирания, падающей на югозапад. У события 1979 г. механизм очага взбрососдвиговый, плоскости падают более полого, но их ориентация и направления сдвиговых движений примерно те же.

Вызывает некоторое сомнение событие 24 октября 1988 2. $(\mathrm{MLH}=5.5, \mathrm{Kp}=10.9, \mathrm{~h}=$ 12 км), произошедшее на продолжении разломной зоны юго-восточнее [Шолохова и др., 1991] Значение магнитуды делает это событие одним из сильнейших в регионе, однако, судя по отсутствию информации о макросейсмических проявлениях землетрясения, возможно его магнитуда завышена и следует доверять оценке энергетического класса Кр $=10.9$, которое в пересчете дает значение магнитуды всего лишь $\mathrm{M}=3.8$. Именно это значение магнитуды оставлено в каталоге.

\section{4. ЯНКАН-ТУКУРИНГРА-ДЖАГДИНСКИЙ РАЙОН (№ 2)}

Сейсмичность этого района связана с системой хребтов, идущей из Забайкалья в виде Яблонового и Олекминского Становика, продолжающихся на территории Амурской области (Джелтулинский становик, Чернышова, Янкан, далее Тукурингра - Соктахан - Джагды). С северовостока эта система ограничена Зейско-Удским прогибом и им отделяется от Станового поднятия [Даммер, 1971], с юго-востока расположен Амурско-Зейский прогиб. Эта зона входит в состав протяженной шовной Монголо-Охотской геосинклинальной складчатой системы, разграничивающей Алдано-Становой и Амурский геоблоки.

Западной и центральной части района № 2 соответствует область максимальных значений сейсмической активности $\mathrm{A}_{10}=0.75-1$ (рис. 5.3) и условной деформации (рис. 5.6), она совпадает с простиранием хребтов Тукурингра и Соктахан, разделенных Зейским водохранилищем и ограниченных с юга и севера Южно- и Северо-Тукурингрскими разломами соответственно. Пиковые значения связаны с очаговыми зонами сильных землетрясений 13 июня 1972 г. $(M=5.6), 2$ ноября 1973 г. $(M=5.5), 23$ июля 1989 г. $(M=5.3)$, 17 июня 2008 г. $(M=5.4)$ и самого сильного в Верхнем Приамурье события за весь период наблюдений 14 октября 2011 г. $(M=6.3)$, произошедшего в районе хребта Янкан.

На самом востоке района в ДжагдиноСелемджинской сейсмогенной зоне (Дж-С) также выделяется область повышенной сейсмической активности, протянувшаяся с юга на север. Однако в области хр. Джагды на рис. 5.3 выделяется сейсмическая брешь, где сильных землетрясений на протяжении инструментальных наблюдений не регистрировалось, да и слабая сейсмичность (рис. 3.2) проявляется редко. Ввиду того что разломно-тектонические структуры на этой территории не прерываются, эта область на картах сейсмического районирования относится к тому же уровню, что и весь восточный участок Монголо-Охотского линеамента [Уломов, Шумилина, 1999]. Л.С. Оскорбин выделил эту территорию в отдельную сейсмогенную зону (Дж). По мнению Р.М. Семенова [Семенов, 1993], отсутствие сильной сейсмичности в районе хр. Джагды объясняется особенностями его геотектонического строения, блок земной коры в районе хребта более консолидирован, отсутствие малых поперечных разрывных дислокаций не способствует разрядке тектонических напряжений в виде умеренно-сильных событий. Потому сейсмичность проявляется в виде редких сильных землетрясений, разделенных продолжительными периодами затишья. Магнитуда возможного землетрясения в этом районе оценивается в $\mathrm{M}=6.5$.

Первое документально зарегистрированное землетрясение в Зейском районе 18 февраля 1889 г. ( $\boldsymbol{M}=4.2, \boldsymbol{h}=7-30 \boldsymbol{\kappa} \boldsymbol{M})$ ощущалось на Зейской пристани силой 7-8 баллов (эпицентр и магнитуда определены по макросейсмическим данным) [Леонов и др., 1977].

Зейское землетрясение 13 июня 1972 2. $(\boldsymbol{M}=\mathbf{5 . 6}, \boldsymbol{h}=18 \boldsymbol{\kappa} \boldsymbol{M})$. Макросейсмические проявления данного события наблюдались на всем протяжении от Якутска до Невера Амурской области. В населенных пунктах Невер, Соловьевск, Стрелка, Лапри отмечались 2-3-балльные эффекты сотрясений. Сотрясения силой до 6 баллов отмечались на расстояниях около 80 км, а пяти - до 200 км, в ближайшем к эпицентру пос. Тынденский $(D=$ 130 км) землетрясение проявилось силой 5 баллов. 
Был слышен сильный гул. Сотрясение ощущали многие жители, некоторые испугались. В момент толчка стены и потолки домов скрипели, звенели стекла окон, сдвигалась с места мебель, падали предметы, стоящие на столах и полках [Козьмин и др., 1976]. Площадь сотрясений составила около

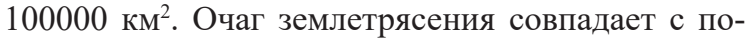
ложением Северо-Тукурингрского разлома (16). Событие, вероятно, стало результатом левосдвиговой сейсмодислокации, вдоль субвертикальной плоскости северо-западного простирания.

Зейское землетрясение 2 ноября 19732. $(\boldsymbol{M}=5.5, \boldsymbol{h}=5-10 \boldsymbol{\kappa} \boldsymbol{M})$ произошло в малонаселенном горнотаежном районе Амурской области [Семенов, Авдеев, 1974; Леонов и др., 1977]. Эпицентр находился на южных отрогах хр. Тукурингра, в 120 км к северу от г. Зея.

Район сотрясений 7-8 баллов в плейстосейстовой зоне Зейского землетрясения ввиду недостатка данных оконтурен с определенной долей условности. Наибольшие сотрясения были отмечены на р. Б. Тынде, в 30 км выше устья. По сообщению охотника И.Н. Дрыгунова, находившегося во время землетрясения на берегу реки, перед колебанием почвы был слышен сильный подземный гул, после чего с интервалом несколько минут последовали два толчка. В результате землетрясения произошли каменные обвалы и осыпи, на реке потрескался лед и повысился уровень воды. Толчки меньшей силы, от которых содрогалось зимовье, ощущались до утра 3 ноября. Слабые толчки и гул отмечались еще в течение 20 дней. На заброшенном прииске Яныр, расположенном в 30-35 км к югу от инструментального эпицентра, землетрясение ощущалось силой 7 баллов. Люди, находившиеся во время землетрясения в бревенчатой избе, в страхе выбежали из нее, а идущие по улице ощутили сначала колебание почвы, а затем резкие толчки, затруднявшие движение. Были сильно напуганы животные. Землетрясение сопровождалось громоподобным гулом.

Максимальное расстояние, на котором ощущалось землетрясение, достигло 280 км. Общая площадь сотрясений - 101000 км². Подробная карта изосейст, составленная по данным 40 обследованных пунктов и 12 почтовых сообщений [Cеменов, Авдеев, 1974], представляет область сотрясений, оконтуренную эллипсами изосейст от 3 до 7 баллов и ориентированных по направлению С3ЮВ. На рис. 5.7 приведена максимальная наблюденная интенсивность [Оскорбин, Бобков, 1997а].

Тип сейсмодислокации в очаге землетрясения классифицируется как сбросо-сдвиговый. Одна из нодальных плоскостей субвертикальна и ориентирована на восток, а вторая, западного простирания, полого падает на северо-северо-запад.

Первое Селемджинское (Джагдинское) землетрясение произошло 29 июня 1975 г. (M= $5.3, \boldsymbol{h}=20-30 \boldsymbol{k} \boldsymbol{m})$ в малоизученном районе на стыке хребтов Джагды и Селемджинского. Оно было зарегистрировано как станциями Бомнак, Кировский и Ясный, так и многими другими сейсмическими станциями Сибири и Дальнего Востока. Селемджинское землетрясение должно было ощущаться жителями ближайших населенных пунктов, но такие сведения не поступили; к тому же оно не подвергалось и специальному макросейсмическому обследованию. Судя по магнитуде 5.3, можно предположить, что сила этого толчка была не менее 7 баллов. Отмечено, что после главного события произошли 3 афтершока.

Очаг Селемджинского землетрясения 29 июня 1975 г. характеризуется близгоризонтальным напряжением сжатия, ориентированным диагонально СВ-Ю3, и напряжением растяжения, ориентированным субвертикально. Одна из возможных плоскостей разрыва (NP1) имеет северо-западное простирание с крутым падением на северо-восток, плоскость (NP2) простирается на юго-восток и довольно полого падает на югозапад. Тип дислокации взброс.

24 ноября 1976 2. в западной части района вблизи пересечения хр. Амазарский и Урушинский произошло землетрясение $(\boldsymbol{M}=\mathbf{5 . 0}, \boldsymbol{h}=$ 27 км). С наибольшей силой землетрясение проявилось в пос. Ерофей Павлович и близлежащих населенных пунктах [Голенецкий, 1980]. Жители просыпались, в испуге выбегали на улицу. Землетрясение ощущалось и вне помещений. В деревянных домах осыпалась штукатурка, растрескивались кирпичные печи, в панельных зданиях на стыках стен и потолочных перекрытий появились трещины, кое-где лопались стекла окон, с полок падали книги и посуда, сдвигались тяжелые предметы. Слышался сильный подземный гул. Сотрясения в 5 баллов отмечены на расстоянии примерно до 50 км, затухание балльности с расстоянием в восточном и западном направлениях различалось мало - к востоку оно было несколько слабее. Из-за отсутствия информации изосейсты с севера и юга остаются незамкнутыми [Голенецкий, 1980]. По сообщению начальника гидрометеорологической станции в пос. Ерофей Павлович Е.И. Комогорцева, повторные толчки ощущались через 30-45 мин, а затем спустя 40 часов. Все они сопровождались гулом, согласно результатам обработки инструментальных данных энергети- 
ческий класс этих событий невелик $(K p=9-10)$. Самый сильный афтершок произошел 3.12.1976 г. $(M=4.4, h=12$ км), который также сопровождался гулом. Имеются сведения, что он ощущался в пос. Ерофей Павлович, Глухарево, Сивачи, Ороченский, Аячи силой 4-5 баллов.

Механизм очага землетрясения классифицируется как взбросо-сдвиговый, нодальная плоскость NP1 восточного простирания и крутого южного падения совпадает по простиранию с Монголо-Охотским разломом (14), небольшая сдвиговая компонента вдоль нее является левосторонней. Альтернативная нодальная плоскость NP2 северо-западного простирания полого падает на северо-восток.

Огоронское землетрясение 16 августа 1977 z. $(\boldsymbol{M}=\mathbf{5 . 0}, \boldsymbol{h}=\mathbf{5 - 2 0} \boldsymbol{\kappa \boldsymbol { M }})$. Очаг землетрясения, видимо, приурочен к продолжению СевероТукурингрского разлома субширотного простирания в районе стыка хребтов Соктахан и Джагды.

Землетрясение ощущалось в пос. Бомнак и вдоль трассы БАМа к северу от эпицентра интенсивностью 5 баллов. Подземный толчок замечен всеми людьми, находившимися в зданиях и на открытом воздухе. Спавшие проснулись и в испуге выходили из домов. Дребезжали оконные стекла и посуда, колебались висячие предметы, падали предметы на столах и с полок. Был слышен подземный гул, как при сильном взрыве. Интенсивность сотрясений в пос. Зейск была примерно на один балл ниже, чем в пос. Бомнак, хотя пос. Зейск расположен ближе к эпицентру землетрясения [Видовский и др., 1981]. Возможно, это связано с различием в инженерно-геологических условиях.

В г. Зея и населенных пунктах Ясный и Октябрьский землетрясения ощущали люди, находившиеся в зданиях в спокойном состоянии. На территории, оконтуренной 3-балльной изосейстой, сейсмический эффект проявился неравномерно, фиксировались изменения сотрясений от 2 до 4 баллов. Изосейсты Огоронского землетрясения имеют форму эллипса, большая ось которого ориентирована субмеридионально, вкрест простирания геологических структур. Средние радиусы изосейст равны: 7-балльная изосейста 10 км; 5-балльная - 26-52 км; 4-балльная - 95 км; 3-балльная - 150 км [Видовский и др., 1981], рис. 5.7. Общая площадь сотрясений при Огорон-

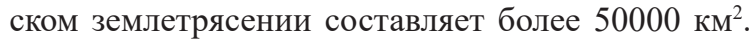
После главного события была зарегистрирована серия афтершоков, некоторые из них ощущались в пос. Бомнак силой до 3 баллов (по данным [Парфенов и др., 1987]).
Очаг Огоронского землетрясения 16 августа 1977 г. характеризуется горизонтальным напряжением сжатия, ориентированным на восток-северовосток, и горизонтальным напряжением растяжения северо-северо-западного простирания. Тип дислокации сдвиг, правосторонний по NP1 югоюго-западного простирания и левосторонний по NP2 восток-юго-восточного простирания.

Тынденское землетрясение произошло 25 февраля 1980 2. $(\boldsymbol{M}=4.2, \boldsymbol{h}=20$ км). Землетрясение тяготеет к Тукурингра-Становому межгорному понижению, к узлу пересечения разрывных нарушений северо-западного, широтного и северовосточного простираний. Наибольшие сейсмические эффекты наблюдались в пос. Первомайский, Сигикта, Тында, Восточный, аэропорт ( $\Delta=5-20$ км) - 5 баллов; пос. Кувыкта, Цыганка, Беленькая, Силип, Янкан ( $\Delta=5-20$ км) - 4 балла; пос. Могот, Хорочи $(\Delta=50-72$ км $)$ - 3 балла; пос. Джуваскит, Золотая Гора, Перевоз Гилюй, Кировский $(\Delta=$ 117-160 км) - 2-3 балла. Землетрясение ощущали все жители, находившиеся в помещениях, и некоторые под открытым небом. Отмечалось общее колебание домов, звенели стекла окон, скрипели полы и потолки, раскачивались висячие предметы, выплескивалась жидкость из сосудов, подпрыгивали книги на полках, падали неустойчивые предметы. Открывались и закрывались двери, в зданиях появились тонкие трещины в кирпичных печах. Общая площадь ощутимых сотрясений составила 15000 км². Эпицентр Тынденского землетрясения, вероятнее всего, приурочен к узловому пересечению Гетканского, Тынденского и других разломов северо-восточного и северо-западного простирания, находящемуся восточнее г. Тынды [Оскорбин и др., 1983].

Второе Селемджинское землетрясение произошло 30 июля 1983 г. $(M=4.8, h=10-15$ км). Эпицентр землетрясения приурочен к Селемджинскому хребту и расположен в 20 км северовосточнее эпицентра 29 июня 1975 г. Землетрясение ощущалось жителями близрасположенных населенных пунктов примерно с одинаковой интенсивностью в пос. Союзный, Токур, Экимчан, Огоджа $(\Delta=30-60$ км $)$ - 4 балла; пос. Стойба $(\Delta=$ 80 км) - 3-4 балла. Второе Селемджинское землетрясение сопровождалось афтершоками, произошедшими в июле-августе с $K p \leq 8.4$. Сведения о сотрясениях более высоких баллов отсутствуют, так как эпицентральная область землетрясения охватывает ненаселенную местность [Оскорбин и др., 1986]. Эпицентры Селемджинских землетрясений приурочены к морфоструктурному узлу, 
образованному пересечением Алданско-Приамурского регионального глубинного шва с СевероТукурингрским разломом, а последнее из них - к району схождения хребтов Джагдинского и Селемджинского.

Очаг Селемджинского землетрясения 30 июля 1983 г. характеризуется близгоризонтальным напряжением сжатия СВ-Ю3, и более крутым напряжением растяжения, тип сейсмодислокации - взбросо-сдвиговый. Одна из возможных плоскостей разрыва имеет почти меридиональное простирание вкрест оси Селемджинского хребта, падает на запад, направление сдвиговой компоненты вдоль нее правостороннее. Вторая имеет запад-северо-западное простирание с падением на северо-северо-восток и левую подвижку вдоль нее.

Землетрясение 23 июля 1989 z. (M = 5.3, $\boldsymbol{h}=13 \boldsymbol{\kappa} \boldsymbol{M})$ произошло западнее пос. Тында, оно имело заметный макросейсмический эффект (4-5 баллов) и вызвало большую серию повторных толчков с $K p=7-10$. Землетрясение ощущалось в пос. Беленькая, в 50 км от эпицентра, интенсивностью 4-5 баллов; в пос. Соловьевск, Тында $(\Delta=55-60$ км) с интенсивностью 4 балла; в г. Зея, пос. Магдагачи, Овсянка, Береговое $(\Delta=$ 150 км) - 3-4 балла. Очаг землетрясения характеризуется близгоризонтальным напряжением сжатия, ориентированным субширотно, тип дислокации - взброс с небольшой сдвиговой компонентой. Нодальная плоскость NP1 северного простирания полого падает на восток, вторая плоскость юго-юго-восточного простирания более круто падет на запад.

Зейское землетрясение 17 июня 2008 2. $(\boldsymbol{M}=5.4, \boldsymbol{h}=16 \boldsymbol{\kappa} \boldsymbol{M})$ произошло в зоне хр. Соктахан, восточнее Зейского водохранилища [Коваленко и др., 2015]. Согласно собранным макросейсмическим данным, землетрясение ощущалось в близлежащем к эпицентру г. Зея $(\Delta=52$ км) интенсивностью 4-5 баллов, в пос. Горный ( $\Delta=82$ км), Бомнак $(\Delta=96$ км), Октябрьский $(\Delta=115$ км) до 4 баллов. К сожалению, более подробных сведений о макросейсмических проявлениях получить не удалось. Землетрясение сопровождалось слабой афтершоковой активностью, до конца года зарегистрировано семь афтершоков с $K p \leq 10$.

Очаг землетрясения характеризуется горизонтальным напряжением сжатия, ориентированным на восток-северо-восток, и горизонтальным напряжением растяжения северо-северо-западного простирания. Тип дислокации сдвиг, правосторонний по NP1 юго-юго-западного простирания и левосторонний по NP2 восток-юго-восточного протирания.
Сковородинское землетрясение 14 октября 2011 г. $(\boldsymbol{M}=6.2, \boldsymbol{h}=18 \boldsymbol{\kappa M})$. Это землетрясение стало самым сильным сейсмическим событием, произошедшим в указанном районе за весь период инструментальных сейсмологических наблюдений. Очаг землетрясения локализован в долине р. Крестовка, между хребтами Янкан и Петровский в зоне глубинного Южно-Тукурингрского разлома. Сковородинское землетрясение ощущалось на всей территории Амурской области, на значительной территории Забайкальского края, на юге республики Саха (Якутия), в некоторых населенных пунктах республики Бурятия, Хабаровского края и северных провинциях Китая. В близлежащих населенных пунктах интенсивность сотрясений достигала 7 баллов. Детальная информация о макросейсмических проявлениях Сковородинского землетрясения представлена в статье [Ханчук и др., 2012].

Большое число афтершоков землетрясения было зарегистрировано локальной сетью ИФЗ РАН, работавшей в окрестностях землетрясения в этот период. Облако афтершоков вытянуто в субширотном направлении и почти вертикально погружается на глубину до 20 км. Детальному анализу афтершоковой последовательности и очаговой области землетрясения посвящена статья [Быкова и др., 2015]. В работе [Овсюченко и др., 2012] рассмотрены геологические проявления и макросейсмический эффект землетрясения в ближней зоне, обосновывается зарегистрированная интенсивность в эпицентральной зоне в 8 баллов.

Механизм очага Сковородинского землетрясения - субширотный левосторонний сдвиг вдоль субвертикальной плоскости, что совпадает с типом основных разломных нарушений региона и может служить подтверждением продолжающихся перемещений вдоль западного фланга Южно-Тукурингрского разлома.

\section{5. ЗЕЙСКО-СЕЛЕМДЖИНСКИЙ РАЙОН (№ 3)}

Район является наименее сейсмически активным на территории региона. На карте сейсмической активности (рис. 5.3) по данным за последние 40 лет выделяется лишь одна вытянутая в широтном направлении область, соответствующая очаговой зоне сильного землетрясения 2004 г. и большому числу меньшей силы событий западнее его (рис. 3.2). Однако рис. 5.6 позволяет утверждать, что северная часть района все же несколько более активна, чем южная. На северо-западе района есть еще одно скопление очагов относительно слабых событий, возможно, оно совпадает с оча- 
говой зоной сильного землетрясения 1911 г., если принять во внимание переопределение его положения [Быкова и др., 2015]. Центральные и южные области района слабосейсмичны, хотя и здесь иногда регистрируются землетрясения $(\mathrm{M}=2-3)$.

Землетрясение 6 августа 1911 г. (M=5.0, $\boldsymbol{h}=\mathbf{5 - 2 0} \boldsymbol{\kappa} \boldsymbol{M})$ ощущалось на Зейской пристани силой 7-8 баллов (эпицентр и магнитуда определены по макросейсмическим данным) [Леонов и др., 1977].

Параметры Норского землетрясения 27 января 1923 2. $(M=4.0, h=5-50$ км) также определены по макросейсмическим данным: на прииске Заманчивом ощущались сильные повторные толчки и слышался довольно сильный гул [Попов, 1939].

Землетрясение 16 января 2004 2. (M= 5.0, $\boldsymbol{h}=11 \boldsymbol{\kappa} \boldsymbol{M})$. Эпицентр располагался на территории северной части Амурско-Зейской равнины в 18 км от пос. Октябрьский, в котором оно ощущалось с интенсивностью I $=5$ баллов. В пос. Ясный, г. Зея, пос. Алгач $(\Delta=66-132$ км) интенсивность составила 4 балла, в пос. Ураловка, Верхнезейск ( $\Delta=85-172$ км) интенсивность - 3 балла, в пос. Экимчан ( $\Delta=269$ км) интенсивность -2 балла (рис. 5.7). Данные макросейсмического обследования приведены в работе [Коваленко и др., 2010]. Землетрясение сопровождалось многочисленными афтершоками $(N=102)$, сильнейший из которых 25 января Кр = 11.4 ощущался в пос. Октябрьский интенсивностью 3-4 балла.

\section{6. ТУРАНО-БУРЕИНСКИЙ РАЙОН (№ 4)}

Наиболее обширный Турано-Буреинский район (№ 4) включает в себя множество разломных структур в основном диагонального Ю3-СВ или меридионального простирания. Основой сейсмической активности здесь, по всей видимости, являются параллельные разломы, относящиеся к северному флангу разломной структуры Танлу. Северную часть пересекают продолжающиеся в сторону Охотского моря разломы МонголоОхотской системы.

Зона разлома Танлу (ЗРТ) является одной из активнейших современных разломных систем Восточного Китая, представляет собой крупную структуру земной коры древнего (как минимум мезозойского) и глубинного (мантийного) заложения. ЗРТ протягивается по периферии Азиатского континента более чем на 2000 км, разделяя Амурскую (Китайскую) микроплиты на две части - западную и восточную. Северный фланг ЗРТ характеризуется сравнительно малой современной тектонической активностью и испытывает землетрясения с максимальной магнитудой $\mathrm{M}=6.0$.
Очаговые зоны наиболее крупных сейсмических событий: 23 августа 1888 г. $(\mathrm{M}=5.5)$, 23 декабря 1914 г. $(\mathrm{M}=6.0), 21$ июня 1963 г. $(\mathrm{M}=$ 5.5), 29 августа 1970 г. (M = 5.5) расположены диагонально вдоль основных разломов района Хинганского (110) и Ишу-Харпинского (112). Однако основное поле более слабой сейсмичности (рис. 3.2, 5.8), как и цепь максимумов сейсмической активности и условной деформации (рис. 5.3; 5.6), переходит из диагонального направления на юге района в меридиональное на севере вдоль некой дуги, отсутствующей в используемой в данной работе разломно-тектонической схеме [Тектоника..., 2004], стыкуясь на севере с максимумами сейсмичности Станового пояса. В статье [Имаева и др., 2012] авторы относят эти максимумы сейсмичности к Итун-Иланскому разлому, выделенному в поле сейсмичности и пересекающему шовные зоны Становой и Тукурингра-Джагдинской сутур. Итун-Иланский разлом называется ответвлением ЗРТ и также, как и другие разломы зоны, предполагается правым сдвигом.

На остальной территории района тоже отмечается повышенный уровень сейсмичности в виде рассеянного поля эпицентров землетрясений. Л.С. Оскорбиным здесь выделяется несколько сейсмических зон (ТУ, Бу-Ям, Бд-К, Эв-Ч, Тг-Ча, Н-Ам), описание которых дано выше. Максимумы условной деформации соответствуют очаговым зонам сильнейших землетрясений, в то время как обширный участок повышенной сейсмической активности в юго-западной части района соответствует многочисленной группе относительно небольших (M = 4-5) сейсмических событий в южной части Буреинского хребта. Ниже приведены наиболее значимые события района.

Землетрясение 23 августа 1888 г. (M = 5.5, $\boldsymbol{h}=\mathbf{1 5 - 2 0} \boldsymbol{\kappa} \boldsymbol{M})$. Параметры определены по макросейсмическим данным. Землетрясение ощущалось в г. Хабаровск и на протяжении 400 км по р. Амур, расчетные изосейсты показаны на рис. 5.7 [Оскорбин, 1977].

Землетрясение 4 октября 1888 г. (M = 5.0, $\boldsymbol{h}=\mathbf{5}-\mathbf{2 0} \boldsymbol{\kappa} \boldsymbol{м})$. Наблюденная интенсивность в эпицентре составила $I=6-7$ баллов. Эпицентр землетрясения приурочен к Помпеевскому хребту.

Сильное землетрясение 3 октября 1907 г. $(\boldsymbol{M}=\mathbf{5 . 2}, \boldsymbol{h}=\mathbf{2 0} \boldsymbol{\kappa} \boldsymbol{M})$, эпицентр которого приурочен к Сутарскому хребту, ощущалось на ст. Радде (5 баллов) и в г. Хабаровск (4 балла).

Самым сильным в Турано-Буреинском районе является землетрясение 23 декабря 1914 2. $(\boldsymbol{M}=\mathbf{6 . 0}, \boldsymbol{h}=\mathbf{7 - 3 0} \boldsymbol{\kappa} \boldsymbol{M})$ [Николаев и др., 1989]. Параметры его определены по совместной интерпре- 
тации макросейсмических и инструментальных данных. Это землетрясение ощущалось силой 5 баллов в г. Николаевск-на-Амуре и пос. Мареинском. Эпицентр расположен в 50 км западнее р. Амур в районе хр. Чаятын.

По инструментальным и макросейсмическим данным определены параметры землетрясения 25 ноября 1924 2. ( $M=5.3, h=7-30$ км) с эпицентром близ побережья в Сахалинском заливе. Оно ощущалось в г. Николаевск-на-Амуре 2-3 балла, на небольших островах в северной части Амурского лимана наблюдался сильный подъем воды [Попов, 1939]. Хотя формально это землетрясение находится за принятыми границами региона, это одно из сильных событий Приамурья и должно быть упомянуто.

1 февраля 1929 г. непосредственно в районе г. Николаевска-на-Амуре произошло землетрясение $(\boldsymbol{M}=4.4, \boldsymbol{h}=15 \boldsymbol{\kappa} \boldsymbol{M})$, которое ощущалось силой до 5 баллов и сопровождалось несколькими повторными толчками [Уланов, 1932; Попов, 1939; Даммер, 1971].

К северной левобережной части хребта Малый Хинган приурочен эпицентр подземного толчка 9 апреля 1956 г. (M= 5.0, $\boldsymbol{h}=\mathbf{2 0} \boldsymbol{\kappa} \boldsymbol{M})$ интенсивностью в пос. Лондоко и Теплое Озеро 4 балла.

Землетрясение 21 июня 1963 г. (М = 5.5, $\boldsymbol{h}=11 \boldsymbol{\kappa} \boldsymbol{M})$ произошло в восточной части Борщовского хребта, стало первым и на настоящий момент наиболее сильным из большого числа событий в этом районе. Согласно определенному механизму в очаге землетрясения реализовалась сдвиговая подвижка со значительной взбросовой компонентой вдоль нодальной плоскости NP2 широтного простирания, падающей на север, направление движения вдоль этой плоскости левое, альтернативная плоскость меридионального простирания с правосторонней подвижкой практически вертикальна.

Баджальское землетрясение 29 авгуcma 1970 г. (M = 5.5, h= 30-40 км) ощущалось с наибольшей силой в 6-7 баллов [Оскорбин и др., 1972, 1973]. Очаг землетрясения располагался в 150 км западнее г. Комсомольска-на-Амуре, под Баджальским хребтом, на глубине 30-40 км (по макросейсмическим данным). Плейстосейстовая область охватила в основном безлюдные районы, населенные пункты располагались на эпицентральном расстоянии более 100 км. В пос. Могды и Солнечном отмечены пятибалльные сотрясения на расстояниях 150 км от эпицентра, а в Комсомольске-на-Амуре интенсивность не превышала 4-5 баллов. В г. Хабаровск, удаленном от эпицентра на 270 км, землетрясение едва ощущалось - 2-3 балла. Изосейсты шестого и пятого баллов [Леонов и др., 1977] вытянуты вдоль Баджальского хребта, а изолинии четвертого и третьего баллов раскрываются в северо-западном и юго-восточном направлениях [Оскорбин и др., 1973] (рис. 5.7).

Очаг землетрясения 29 августа 1970 г. характеризуется близгоризонтальным напряжением сжатия, ориентированного меридионально, и более крутым напряжением растяжения, ориентированного широтно. [Парфенов и др., 1987; Николаев и др., 1989]. Одна из возможных плоскостей (NP1) ориентирована субмеридионально и круто падает на запад, вторая возможная плоскость разрыва (NP2) ориентирована на северо-восток и круто падает на юго-восток. Тип сейсмодислокации - взбросо-сдвиг.

Землетрясение 4 ноября 1973 2. (М = 4.7, $\boldsymbol{h}=\mathbf{2 0}-\mathbf{3 0} \boldsymbol{\kappa \boldsymbol { M }})$, эпицентр которого расположен на шельфе в 60 км севернее эпицентра 29 ноября 1924 г., ощущалось в ряде населенных пунктов прилегающих участков Северного Сахалина и Хабаровского края силой 3-4 балла [Оскорбин и др., 1976]. Землетрясение предварялось и сопровождалось рядом слабых толчков Кр $\leq 9.5$.

Тугурское землетрясение 24 марта 19842. $(\boldsymbol{M}=4.5, \boldsymbol{M S H}=5.6, \boldsymbol{h}=5-20 \boldsymbol{\kappa} \boldsymbol{M})$. Очаг располагался под дном Тугурского залива Шантарского моря, на стыке подводного продолжения хребтов Альского и Тугурского.

Тугурское землетрясение сопровождалось двумя форшоками $(K p=8.6, K p=10)$ и двумя афтершоками $(K p=8.8, K p=10.4)$. Сведения о макросейсмических данных отсутствуют. Механизм очага Тугурского землетрясения характеризуется близгоризонтальным напряжением сжатия и почти вертикальным напряжением растяжения, что обусловило взбросо-сдвиговый характер дислокаций в его очаге. Одна из возможных плоскостей разрыва имеет простирание юго-западное (по простиранию Альского хребта) с падением на северо-запад, а вторая ориентирована субширотно (вкрест простирания Альского хребта) с падением на юго-восток. Обе плоскости характеризуются взбросо-сдвиговой подвижкой с преобладанием вертикальной ее компоненты. Отсутствие дополнительных данных (области афтершоков, макросейсмических данных) не позволяет выделить рабочую плоскость.

Землетрясение 5 марта 1987 2. (М = 5.2, $\boldsymbol{h}=16 \boldsymbol{\kappa} \boldsymbol{M})$ произошло в северных отрогах хр. Турана. Глубина, оцененная по фазам $s P-P$ и $p P-P$ составила $h=16 \pm 4$ км, по макросейсмическим данным $h=19 \pm 3$ км. Землетрясение ощущалось 
в Селемджинском районе Амурской области и Верхнебуреинском районе Хабаровского края. Макросейсмическими возмущениями была охва-

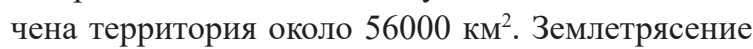
ощущалось в пос. Огоджа $(\Delta=32$ км $)-5$ баллов; пос. Коболдо $(\Delta=55$ км $)-4-5$ баллов; пос. Стойба, Экимчан, Ивановское, Ольгинск, Токур, Златоустовск $(\Delta=65-90$ км $)-4$ балла [Шолохова и др., 1990].

Землетрясению сопутствовали и форшоки $(\kappa p \leq 9)$ и афтершоки $(\kappa p \leq 7.9)$, охватившие область 1800 км², вытянутую вдоль Южно-Тукурингрского разлома (в направлении падения фокальной плоскости $N P 1)$.

Очаг землетрясения 5 марта 1987 г. характеризуется близгоризонтальным напряжением сжатия ориентированным меридионально, и более крутым напряжением растяжения, ориентированным широтно. За рабочую плоскость принята плоскость NP1 юго-восточного простирания с крутым падением на юго-запад. Тип дислокации - сдвиг.

12 января 2007 2. (M=4.7, $h=20 \pm 5$ км) произошло землетрясение севернее Комсомольска-наАмуре (западнее хр. Мяочан), которое ощущалось: пос. Гори $(\Delta=19$ км) и Кондон $(\Delta=28)$ интенсивностью сотрясений $I=5$ баллов, в пос. Эворон $(\Delta=48$ км), Солнечный $(\Delta=50$ км), Горный $(\Delta=$ 53 км) - 4 балла, в Комсомольске-на-Амуре $(\Delta=$ 63 км) - 3 балла. Оно предварялось форшоком 9 января с $K p=8.9$ и сопровождалось небольшим числом афтершоков с $K p=7.2-9.7$, растянувшимися до конца года [Коваленко и др., 2013].

Очаг землетрясения 12 января 2007 г. характеризуется примерно равным наклоном к горизонту осей сжатия северо-восточного простирания и растяжения - юго-западного простирания. Одна из возможных плоскостей разрыва $(N P 1)$ имеет юго-восточное простирание и крутое падение на юго-запад. Плоскость NP2 северо-западного простирания почти вертикальна, тип сеймодислокации - пологий сброс.

Землетрясение 20 мая 2007 2. (М = 4.8, $\boldsymbol{M S H}=\mathbf{5 . 6}, \boldsymbol{h}=\mathbf{1 9} \pm \mathbf{5} \boldsymbol{\kappa} \boldsymbol{M})$ произошло юго-западнее Николаевска-на-Амуре и ощущалось в пос. Тыр ( $\Delta=36$ км), Сусанино ( $\Delta=40$ км) интенсивостью 5 баллов, пос. Тахта $(\Delta=59)$, Богородское $(\Delta=$ 67 км) - 4-5 баллов. Главному событию предшествовали четыре форшока с Кр $=9.3-11.7$. Максимальный форшок произошел 3 мая 2007 г. ( $M=$ $4.2, \mathrm{Kp}=11.7)$ и ощущался интенсивностью $I=3$ балла в пос. Тыр ( $\Delta=45$ км), Сусанино ( $\Delta=48$ км), Тахта $(\Delta=68$ км). Также отмечены три афтершока $K p=8.0-10.9$. Карта макросейсмических проявле- ний приведена в статье [Коваленко и др., 2013].

\section{7. СИХОТЭ-АЛИНСКИЙ РАЙОН (№ 5)}

Этот район для удобства рассмотрения разделим еще на две части: обширную, но слабо сейсмичную северную, и меньшую - южную, отличающуюся значительно большей плотностью населения, где даже относительно слабые события вызывают повышенный интерес.

Очаги наиболее сильных землетрясений района тяготеют к побережью и примыкающей акватории Татарского пролива (события 1924 г. $(M=5.6) ; 1968$ г. $(M=4.7-5.0 ; 1990$ г. $(M=6.2)$ и др.). О слабой сейсмичности говорить сложнее, т.к. представительность каталога на этой территории несколько хуже, но очевидно, что территория Сихотэ-Алиня, несмотря на известные крупные разломы, не проявляла значительную сейсмическую активность за инструментальный период наблюдений.

11 марта 1924 г. в северо-восточных отрогах хр. Хоми произошло довольно сильное землетрясение $(\boldsymbol{M}=\mathbf{5 . 6}, \boldsymbol{K} \boldsymbol{p}=\mathbf{1 4}, \boldsymbol{h}=\mathbf{2 0} \boldsymbol{\kappa} \boldsymbol{M})$. Параметры его определены по совместной интерпретации инструментальных и макросейсмических данных. Оно ощущалось с силой до 5 баллов на участке от оз. Кизи до впадения р. Лимуриа в Амур, а более слабые толчки - в течение февраля и марта 1924 г. [Уланов, 1932].

К рассматриваемому району условно отнесем землетрясение 10 июня 1927 2. (M= 5.0, $\mathrm{h}=$ 5-50 $\boldsymbol{\kappa m})$, эпицентр которого расположен в Татарском проливе (определен неуверенно).

На побережье Татарского пролива в 1968 г. дальневосточной сетью сейсмических станций зарегистрирована серия подземных толчков, эпицентры которых находились в районе пос. Ванино и г. Советская Гавань.

Землетрясение 19 сентября 1968 2. $t_{0}=04: 57: 40(M=4.8, h=22 \boldsymbol{\kappa})$ ощущалось в населенных пунктах Советская Гавань - 5 баллов; Ванино, Датта - 4-5 баллов; Углегорск, Лесогорск, Тельновский, Надеждино, Шахтерск, Орлово 3 балла.

Второе событие 19 сентября 1968 2. $\boldsymbol{t}_{0}=05: 01: 16(\boldsymbol{M}=\mathbf{5 . 0}, \boldsymbol{h}=22 \boldsymbol{\kappa} \boldsymbol{M})$ произошло через 4 мин, но эпицентр его располагался в 35 км севернее в районе пос. Датта. В этот же день были зарегистрированы ряд подземных толчков, которые следует отнести, по-видимому, к афтершокам двух первых землетрясений [Оскорбин, Поплавская, 1972]. Землетрясения ощущались в Датте 5-6 баллов; Ванино, Советская Гавань - 4 балла; Углегорск, Тельновский, Надеждино, Шахтерск - 
3-4 балла; Орлово, Лесогорск - 2-3 балла. Отмечался гул, умеренное раскачивание висячих предметов, звон посуды и оконных стекол. На некоторых домах были частично разрушены кирпичные трубы, в обогревателе одного из домов образовалась сквозная трещина.

Третье землетрясение произошло 13 октября 1968 г. $(\boldsymbol{M}=4.7, \boldsymbol{h}=30$ км). Подземный толчок жители пос. Датта ощущали силой до 5 баллов, в г. Углегорск - около 3 баллов.

7 декабря 1980 2. $(M=4.7, h=30$ км) произошло землетрясение с эпицентром в центральной части Южного Сихотэ-Алиня. Землетрясения такой силы и с очагом в пределах земной коры ранее, по крайней мере с 1962 г., здесь, по-видимому, не происходили. Отсутствие близрасположенных сейсмических станций не позволяет говорить о форшоковой и афтершоковой деятельности, связанной с этим землетрясением. Сведения о макросейсмических данных отсутствуют [Оскорбин и др., 1980].

Землетрясение 13 ноября 1990 года (М= 6.2, $\boldsymbol{M S H}=6.4 ; h=16 \pm 4$ кM) произошло в южной части Татарского полива (северной части Японского моря) и ощущалось на территории Приморского и Хабаровского краев, а также на западном побережье о. Сахалин. Как показывает анализ сейсмичности в предыдущие годы, событий, подобных описываемому, в изучаемом районе ранее не отмечалось. Отсутствовали также сейсмические события, непосредственно предшествовавшие Приморскому землетрясению. Однако само оно спровоцировало мощную серию афтершоков, продолжавшуюся до конца 1990 г. [Поплавская и др., 1996]. По данным детального макросейсмического обследования, в ближайших к очагу населенных пунктах побережья пос. Усть-Соболевка, Кузнецово, Максимовка, Светлая, Ямгу наблюдаемый макросейсмический эффект достигал 5-6 баллов, в пос. Единка, Малая Кема - 4-5 баллов. Зона макросейсмических возмущений вытянута на юго-запад в направлении вспарывания разрыва $\left(\mathrm{Az}_{\text {вспар }} \approx 225^{\circ}\right)$. Граница ощущаемости на юго-западе проходит в 600 км от очага, на северо-западе в 360-375 км и на северо-востоке в 285-295 км (рис. 5.7).

Очаг землетрясения характеризуется близгоризонтальным напряжением сжатия, ориентированным субширотно, и растяжения в меридиональном направлении, тип дислокации - сдвиг. По обеим альтернативным плоскостям происходили сдвигонадвиги с преобладанием сдвиговой компоненты подвижки. Сопоставление $\mathrm{Az}_{\text {разр }}$ с прости- ранием (STK) нодальных плоскостей позволило выбрать в качестве плоскости-сместителя в очаге плоскость с простиранием STK $=226^{\circ}$ и падением под континент DP $=75^{\circ}$ [Поплавская и др., 1996].

По данным о механизме очага Приморского землетрясения разлом в очаге является коровым левосторонним взбросо-сдвигом или надвигосдвигом, по которому позднемезозойское орогенно-складчатое сооружение Сихотэ-Алиня взброшено или надвинуто и смещено на юго-запад относительно Татарского пролива.

Более подробно рассмотрим Южно-Приморский район. Здесь наиболее сильные сейсмические события произошли в 1962 и 1967 гг., поэтому на карте сейсмической активности (построенной на основе данных 1975-2015 гг.) этот район выражен слабо. Зато карта условной деформации (рис. 5.6), как и карта эпицентров (рис 5.8), демонстрируют, что сейсмическую активность Южного Приморья можно отнести к умереннослабой. Согласно собранной макросейсмической информации, здесь неоднократно регистрировались сотрясения интенсивностью I = 7 баллов.

Территориально очаги ощутимых землетрясений разделяются на три группы:

- Партизанскую: события 1933 г. $(\mathrm{M}=4.5)$; 1962 г. $(\mathrm{M}=2.7) ; 1971$ г. $(\mathrm{M}=4.1)$;

- Владивостокскую: события 1950 г. $(\mathrm{M}=4.1)$; 1955 г. $(\mathrm{M}=4.4)$;

- Ханкайскую: события 1962 г. $(\mathrm{M}=5)$;

2 события 1967 г. $(M=5) ; 2003$ г. $(M=4.4)$ и 2014 г. $(\mathrm{M}=4.4)$.

На рис. 5.9 показаны изосейсты наиболее значимых ощутимых коровых землетрясений Приморья.

Первое достоверно зафиксированное землетрясение в Приморье произошло 19 сентября 1933 2. $(\boldsymbol{M}=4.5 ; \boldsymbol{h}=8$ км). Описание подробностей не сохранилось. Для него характерна малая глубина очага. В пос. Партизанск оно ощущалось как 7-балльное землетрясение, на расстоянии 6-7 км от центра поселка как 4-5-балльное. Инструментальных данных землетрясения нет [Мирошников, 1974; Органов, 1962а]. Изосейсты по М.Г. Органову имеют северо-северо-восточное направление. Сведения собраны Л.П. Крыжневой и Г.П. Чермных (сейсмическая станция Владивосток) путем опроса местных жителей. Землетрясение 1933 г. по своим проявлениям сходно с землетрясением 1962 г. (рис. 5.9). 


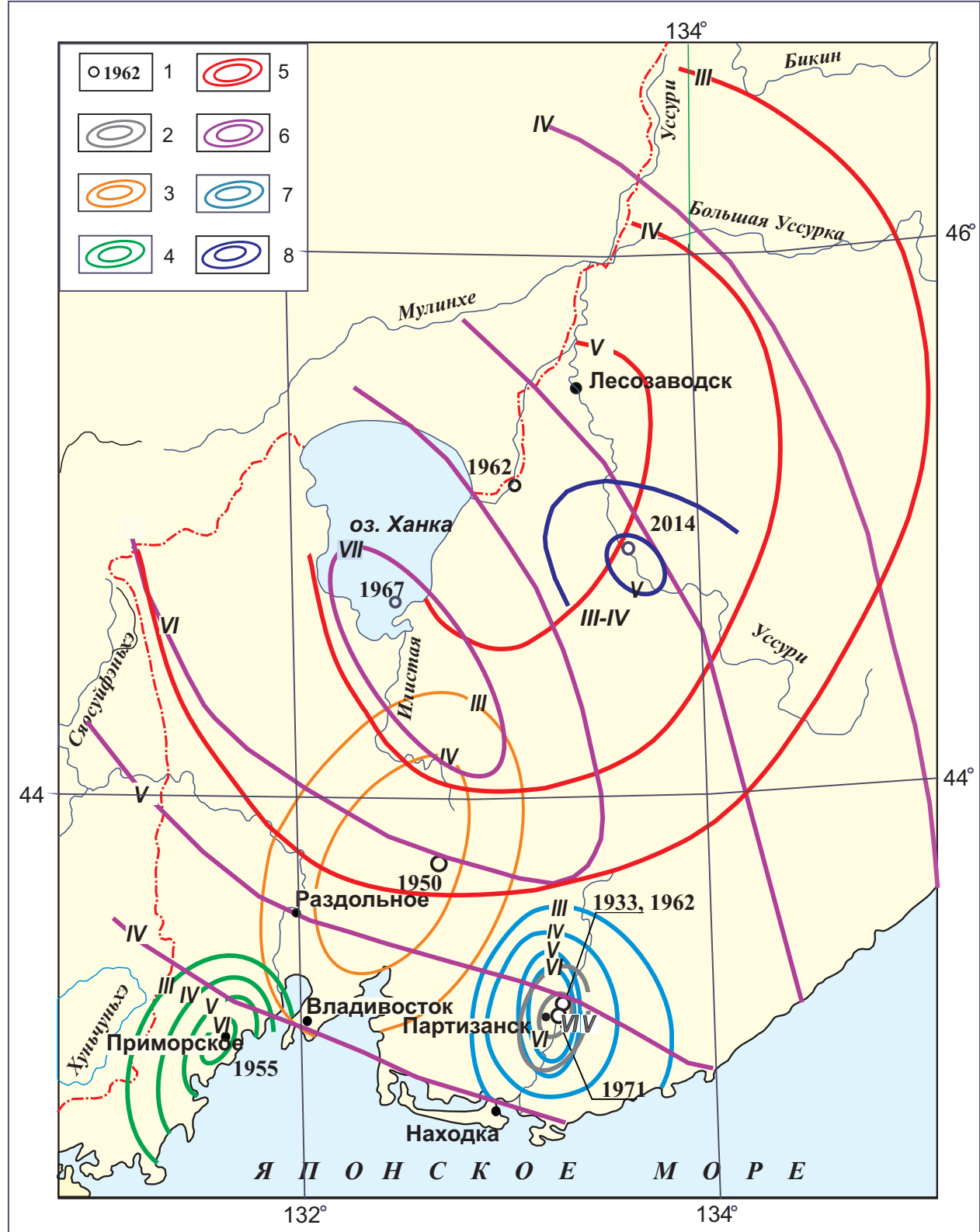

Рис. 5.9. Схема изосейст коровых землетрясений Южного Приморья 1933-2014 гг. Составлена на основе работ [Органова, 1980; Органова, Кручинина, 1978; Леонов и др., 1977; Чермных, 1972] и материалов авторов. 1 эпицентр и год землетрясений; 2 - изосейсты Партизанских землетрясений 1933 и 1962 г.; 3 - Артем-Шкотовского 1950 г.; 4 - Приморского 1955 г.; 5 - Лесозаводского 1962 г.; 6 - Ханканского 1967 г.; 7 - Николаевского 1971 г.; 8 - землетрясения 12 апреля 2014 г. Римскими цифрами подписаны изосейсты соответствующего балла.

Артем-Шкотовское землетрясение произошло 10 октября 1950 2. (M=4.1, $h=14$ км), ощущалось на большой площади от пос. Шкотово до с. Ивановка и от Тереховки до Ново-Хатуничей. В г. Владивостоке, Уссурийске и окрестностях пос. Кангауз сила сотрясений составила 3 балла. М.Г. Органов, собрав сведения в 19 населенных пунктах, построил схему изосейст, вытянутых в северо-восточном направлении в соответствии с тектоническими структурами района. Пло- щадь 4-балльных сотрясений составила 900 км², 3-балльных - 3500 км² (рис. 5.9) [Органова, 1980]. Инструментальных данных нет.

Приморское землетрясение 14 сентября 1955 2. в районе ст. Приморская (M=4.4; $h=$ 6 км) с эпицентром в пос. Кедровая Падь. Макросейсмические проявления землетрясения в ближайших к эпицентру населенных пунктах соответствуют воздействиям в 7 баллов [Леонов и др., 1977]. 
В пос. Приморский были повреждены все постройки, во многих зданиях разрушились печи, упали трубы. На склонах гор произошли небольшие обвалы. По данным Н.М. Органовой и Л.М. Кручининой [Органова, Кручинина, 1978], образовались трещины в земной поверхности, в воздухе отмечалась запыленность. Землетрясение сопровождалось невысокой морской волной, отмеченной на побережье п-ова Песчаный, Эгершелд, бух. Нарва. Образовался водяной столб в Амурском заливе в 0.5 км от устья р. Барабашевка. По-видимому, здесь имело место подводное оползание илистых осадков с юго-западного Муравьевского порога, что привело к некоторому изменению рельефа дна залива [Органова, Кручинина, 1978; Олейников, Олейников, 2009]. Изосейсты вытянуты в северо-восточном направлении на 200 км и резко сужены (до 25 км) вкрест простирания основных геологических структур [Леонов и др., 1977; Олейников, Олейников, 2009]. Площадь 7-балльных сотрясений составила 50 км², 6-балльных - 610 км² $^{2}$ 5-балльных - 800 км² $^{2}$ (рассчитаны по схеме Н.М. Органовой [Органова, Кручинина, 1978]). По макросейсмическим опросным данным максимум сотрясений приходится на район ст. Приморская. Вывалы камней со склонов наблюдал лесник в долине руч. Золотой. В пос. Кедровая Падь ощущались три толчка. Почти все свидетели слышали направление гула (с моря и с юга), но были толчки и с северо-востока, и даже юго-запада. Во Владивостоке и на ст. Океанской ощущалось землетрясение силой в 3 балла. Инструментальных данных нет.

Лесозаводское землетрясение произошло 15 августа 1962 2. $(M=5.0 ; h=30$ kM). По данным Л.Д. Мирошникова, землетрясение ощущалось силой до 6 баллов в г. Лесозаводске и силой до 3 баллов в г. Владивосток. Во время толчка отмечено смещение предметов с ЮВ на СЗ. Наблюдалось качание деревьев, падение висящих на стенах предметов, остановка часов, хлопанье дверей и осыпание штукатурки. По данным М.Г. Органова, Лесозаводское землетрясение ощущалось силой 6 баллов, магнитуда $\mathrm{M}=5.5$ глубина очага 37 км, эпицентр в 42 км юго-западнее г. Лесозаводска в долине р. Сунгач, изосейсты северо-восточного простирания. На основании обработки макросейсмических материалов (рис. 5.9) 5-балльные изосейсты протягиваются через район поселков: Филаретовка, Тургенево, Еленовка, Преображенка, Татьяновка, Прохоры и выходят к побережью оз. Ханка между реками Спасовкой и Илистой [Органова, 1980]. 4-балльная изосейста проходит между г. Дальнереченском и пос. Сухановкой, затем идет через поселки Новотроицкое,
Орехово, Самарку, Кокшаровку, Анучино, Ляличи, Ярославский и Камень-Рыболова. 3-балльная изосейста - южнее ст. Бикин, восточнее г. Лучегорска и пос. Заветного, через пос. Извилинку, г. Уссуриск, пос. Пограничный и Краево. Плейстосейстовая область располагалась в пределах Ханкайского массива, на кристаллическом фундаменте которого с мелового времени формировались унаследованные прогибы и наложенные впадины. По данным ГСЗ, земная кора этого района разбита коровыми и глубинными разломами на блоки. Н.М. Органова считает, что плейстосейстовая область располагается в полосе сочленения слабых отрицательных и положительных изостатических аномалий северо-восточного и северо-западного простирания. Район характеризуется недостатком мощности земной коры в пределах 2 км. Таким образом, кора находится в несколько нарушенном изостатическом состоянии.

Землетрясение 1 сентября 1962 2. (M = $2.7, \boldsymbol{h}=1-2.5 \boldsymbol{\kappa} \boldsymbol{M})$ сопровождалось сильным гулом, форшоками и афтершоками меньшей силы (5 событий). На территории г. Партизанск и пос. Углекаменск интенсивность достигала 7 баллов. 6-балльная зона имела простирание ССВ и занимала площадь до $6 \mathrm{kм}^{2}$. 5-балльная зона ох-

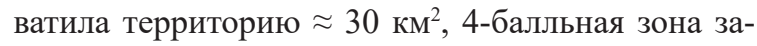

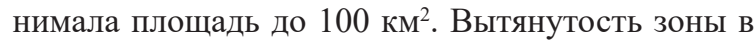
направлении ССВ приближается к простиранию складчатых структур района, несколько отклоняясь в меридиональном направлении [Леонов и др., 1977; Мирошников, 1974; Органов, 1962а, 1962б].

Ханкайское землетрясение зарегистрировано 15 августа 1967 2, $t_{0}=15: 36: 06$ ( $M=5.0$; $\boldsymbol{h}=\mathbf{2 0} \boldsymbol{\kappa м})$ [Леонов и др., 1977]. Сейсмическая станция Владивосток зарегистрировала землетрясение с эпицентром в районе оз. Ханка в 155 км к северу от г. Владивостока. Землетрясение ощущалось примерно на $3 / 4$ площади Приморского края, а в ближайших к эпицентру пунктах значительно повредило сельские постройки. После основного события был отмечен ряд афтершоков, которые ощущались в радиусе 25 км и более.

В плейстосейстовой области был слышен глухой раскатистый подземный гул, частично разрушились кирпичные печи, дымоходные трубы. Падали куски штукатурки, открывались и закрывались окна и двери, скрипела мебель, падали и сдвигались с места предметы. В пос. Новая Девица отмечено повышение уровня воды в колодце. Спавшие жители проснулись и в панике выбегали из домов в поселках Сиваковка, Новая-Девица, Черниговка, Камень-Рыболов, Манзовка, СпаскДальний, Реттиховка, Хороль, Анучино, Астро- 
Глава 5. Сейсмичность Приамурья и Приморья

ханка, Сантахеза, Ярославский, Липовцы, Пограничный, Турий Рог, Ильинка ( $\Delta=9-88$ км).

7-8-балльные сотрясения наблюдались на эпицентральных расстояниях до 50 км, в направлении пос. Анучино - 87 км. Это свидетельствует о вытянутости изосейст Ханканского землетрясения в ЮВ направлении (рис. 5.9). Максимальное расстояние, на котором ощущалось землетрясение, составляет 225 км. Общая площадь сотрясе-

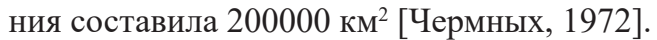

Эпицентральная зона Ханкайского и Лесозаводского землетрясений располагается на границах впадины, наложенной на Ханкайском массиве и выполненной мезозойскими осадками. Отдельные южные участки этой впадины на тот момент испытывали подъем со скоростью 1 мм/год [Ивашинников, 1973], а северная ее часть, наоборот, погружалась. Возможно, что подобными контрастными подвижками и объясняется возникновение этих землетрясений [Леонов и др., 1977].

Землетрясение 15 августа 1967 2., $t_{0}=17: 41: 49(M=5.0 ; \boldsymbol{h}=20)$ в районе пос. Преображение, Лазовского района (побережье Японского моря восточнее бухты Судзухе) сейсмостанциями не зарегистрировано, но ощущалось многими людьми, находившимися в помещениях и на открытом воздухе. Спавшие просыпались и в испуге выбегали из домов. В деревянных домах скрипели полы и стены, дребезжали оконные стекла, в многоэтажных домах падали легкие предметы, посуда. Домашние животные и птицы проявляли беспокойство. Инструментальных данных нет [Поплавская и др., 1970].

Землетрясение 18 декабря 1971 2. (M=4.1, $\boldsymbol{h}=5-7 \boldsymbol{\kappa} \boldsymbol{M})$ произошло в районе пос. Николаевка, с изосейстами по Г.П. Чермных северо-западного простирания [Органова, 1980]. Землетрясение сопровождалось взрывоподобным гулом низкого тона. Интенсивность сотрясения резко убывала - на расстоянии 25 км к северу и 45-50 км к юго-востоку она не превышала 3 баллов. Локальный эффект свидетельствует об очень небольшой глубине очага. Особо резкое затухание эффекта землетрясения наблюдается вдоль Южно-СихотэАлинской шовной зоны, так как к югу сейсмические колебания свободно распространялись на расстояние до 70-80 км [Леонов и др., 1977].

7 октября 2003 г. $(M=4.4 ; \boldsymbol{h}=30$ км) произошло землетрясение в районе пос. Марьяновка (оз. Ханка), ощущавшееся в близлежащих поселках интенсивностью до 3-4 баллов на расстоянии до 89 км и 2-3 баллов на расстоянии 136 км. Вероятнее всего за счет большой глубины очага макросейсмический эффект землетрясения был незначительный.
Землетрясение 12 апреля 2014 2. (MPV(A) = $4.5, \boldsymbol{h}=14 \boldsymbol{\kappa} \boldsymbol{M})$ произошло в районе пос. Межгорье восточнее оз. Ханка. Наиболее сильно ощущалось в поселках Межгорье, Крыловка, Марьяновка, расположенных на расстоянии 4-13 км от эпицентра, где интенсивность составила 5 баллов. С расстоянием интенсивность сотрясений закономерно спадает, однако известно об ощутимых эффектах в 2-3 балла на расстояниях 150-180 км от эпицентра. Детального макросейсмического обследования плейстосейстовой области не проводилось. Информация получена по телефону, а так же из опросных листов, собранных Н.В. Шестаковым. На рис. 5.9 приведена изосейста 5 баллов и частично изосейта 3-4 балла. Землетрясение ощущалось в поселках Дальнереченск и Смычка на расстояниях 150-180 км от эпицентра силой 2-3 балла, что свидетельствует о вытянутости изосейст землетрясения в ЮВ направлении.

В плейстосейстовой области был слышен сильный подземный гул, из межпотолочных плит осыпалась штукатурка, образовались трещины в углах и на стенах домов (3-5 мм), деформировались обои, падали мелкие предметы. Спящие проснулись, многие жители вышли на улицу. Единственный афтершок этого землетрясения был зарегистрирован спустя 36 минут после основного события.

Тип дислокации в очаге землетрясения сдвиг, возможны два направления плоскости подвижки: субширотное (NP1, левый сдвиг) либо субмеридиональное (NP2, правый сдвиг) [Шестаков и др., 2018$].$

\section{8. ПРИГРАНИЧНЫЙ РАЙОН (№ 6)}

Здесь собраны сведения о наиболее сильных сейсмических событиях, эпицентры которых произошли на территории Китая, однако их макросейсмический эффект мог проявиться в населенных пунктах СССР/РФ, потому эта территория также входит в зону ответственности СФ ФИЦ ЕГС РАН. В основном это горные районы северной части Большого и Малого Хингана, СреднеАмурской равнины, горные области к западу от оз. Ханка.

Самое сильное землетрясение здесь произошло 3 июля 1902 2. (М оценивается в 6.6, $\boldsymbol{h} \sim 20 \boldsymbol{\kappa} \boldsymbol{M})$ в восточных отрогах хребта Лаоелин. Наибольшая известная интенсивность составила 6 баллов на расстоянии $\Delta=60$ км. Эпицентр находился за пределами нынешних границ региона

Землетрясение 17 сентября 1931 2. (М = $5.5, \boldsymbol{h}=\mathbf{5 0 - 1 2 0} \boldsymbol{\kappa} \boldsymbol{M})$. Основные параметры определены по макросейсмическим данным. Эпицентр находился на границе с Китаем, в районе Мало- 
го Хингана. Макросейсмические данные представлены в работе [Попов, 1939]. Землетрясение ощущалось в г. Благовещенск силой 6 баллов. В некоторых домах образовались трещины, окна звенели, двери сами открывались, слышался подземный гул. В пос. Чекунде (на р. Бурее) - силой в 5 баллов, отмечено волнообразное движение почвы, звенела посуда, одна женщина упала с постели. В селах Кучея (Хингано-Архангельского района) шаталась мебель. Наблюдалось пять отдельных толчков, в пос. Амурском (зерносовхозе) два толчка средней силы. На ст. Козырновской (на телеграфе 3 толчка) - 4-5 баллов. В пос. Домикан наблюдалось колебание почвы, с полок падали мелкие предметы, слышался гул и трещали стропила крыш. Землетрясение охватило большой район, на рис. 5.7 приведены расчетные круговые изосейсты.

Сильные землетрясения произошли 1 сентября 1942 г. $(M=5.7, h=20$ км) в зоне влияния разлома Намурхэ в 100 км южнее г. Благовещенск и 23 декабря 1948 г. $(M=5.2, h=15$ км) к западу от оз. Ханка. Данные по макросейсмическим проявлениям этих событий отсутствуют.

Серия событий 1986 г. в районе Малого Хингана оказалась уникальной для региона. Первое землетрясение произошло 9 февраля 1986 г. $(\boldsymbol{M}=5.1, \boldsymbol{h}=15 \boldsymbol{\kappa} \boldsymbol{M})$, оно вызвало 4-балльные сотрясения в г. Благовещенск и пос. Константинов- ка, где отмечался слабый звон посуды, дрожание мебели, из полных чашек выплескивалась вода.

Второе землетрясение произошло 28 февраля 1986 г. $(M=5.7, h=13 \boldsymbol{\kappa M})$ и ощущалось в тех же населенных пунктах, но силой 5-6 баллов. В некоторых зданиях образовались тонкие трещины между стыками панелей. Жители слышали скрип полов и тонких перегородок, звенела посуда, наблюдалось опрокидывание торшера.

15 августа 1986 г. в 17:53 произошло событие $(\boldsymbol{M}=4.9, \boldsymbol{h}=16 \boldsymbol{\kappa} \boldsymbol{M})$, после которого в этот же день в 20:20 последовало землетрясение ( $\boldsymbol{M}=$ $5.6 ; \boldsymbol{h}=14 \boldsymbol{\kappa} \boldsymbol{M})$, ощущавшееся в г. Благовещенск и пос. Константиновка силой 5 баллов. Люди проснулись, слышалось дребезжание посуды и оконных стекол, было замечено колебание висячих предметов, слышался гул. Гипоцентральная область описываемой серии землетрясений находилась под воздействием горизонтальных напряжений сжатия, ориентированных субширотно, и более крутых растягивающих напряжений менее устойчивой ориентации. Подвижки в очагах землетрясений были преимущественно взбросового типа [Шолохова и др., 1989].

1 октября 1993 2. $(M=5.0, h=20 \kappa M)$ в южных отрогах Помпеевского хребта на границе с Китаем произошло землетрясение, которое ощущалось в г. Биробиджан ( $\Delta=210$ км) интенсивностью 3-4 балла. 


\section{ГЛАВА 6}

\section{РЕКОНСТРУКЦИЯ ТЕКТОНИЧЕСКИХ НАПРЯЖЕНИЙ В КОРЕ И МАНТИИ РЕГИОНА}

Изучение сейсмотектоники Приамурья и Приморья несколько тормозит дефицит данных о механизмах очагов происходящих здесь землетрясений, что обусловлено как относительно низкой сейсмичностью территории, так и слабой развитостью сейсмологической сети, применяемой для рутинных сейсмологических наблюдений: созданная в СССР система сейсмического мониторинга не только не развивается, а наоборот, приходит в упадок.

Тем не менее, к настоящему моменту Сахалинскому филиалу ФИЦ ЕГС РАН удалось накопить каталог механизмов очагов землетрясений Приамурья и Приморья, включающий информацию о 109 землетрясениях, произошедших в период с 1963 по 2014 г., 52 из которых относятся к глубокофокусным (мантийным) событиям (рис. 6.3), 57 - к коровым (рис 6.7). С учетом значительной площади региона это количество невелико, но при этом позволяет провести оценку поля тектонических напряжений региона.

Определение параметров очага землетрясения в приближении двойного диполя осуществлялось с использованием программы «Механизм» [Аптекман и др., 1979] методом полярности первых вступлений в $P$-волне $(P g, P n, p P)$. Полученные решения, при возможности, уточнялись путем привлечения (вручную) знаков $S V$-, $S H$-, $S V G$-, $S H G$-волн с использованием теоретических палеток нодальных линий для $S V$ - и $S H$-волн [Балакина, 1972]. Детально особенности методики и ее реализации в программном пакете описаны в работах [Поплавская и др., 1989, 2001; Коновалов и др., 2014].

Примерное качество каталога можно оценить по рис. 6.1, где показано распределение событий с известными механизмами очага во времени. Наибольшее количество механизмов коровых землетрясений приходится на 1980-е - начало 2000 гг., после чего число полученных решений значительно сокращается. Определение механиз- мов очагов глубокофокусных землетрясений, напротив, увеличивается к началу 2000-х годов. О представительности полученного каталога говорить не приходится, однако магнитудный диапазон событий в нем довольно велик.

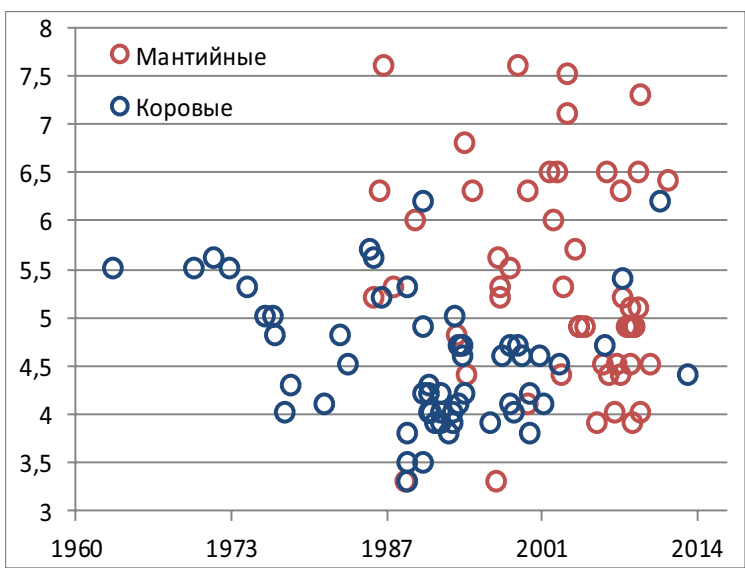

Рис. 6.1. Распределение землетрясений с известным механизмом очага во времени.

На рис. 6.2 показано распределение полученных решений по типу сейсмодислокации в очаге согласно классификации, принятой в СФ ГС РАН (гл. 3).

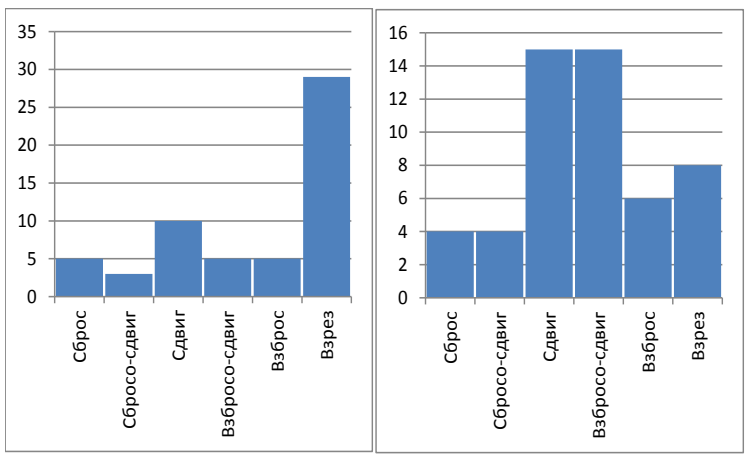

Рис. 6.2. Распределение механизмов очагов землетрясений (Приложение 2) по типу сейсмодислокации: а коровые землетрясения (глубина $\mathrm{h}<50$ км); б - глубокие землетрясения (глубина $\mathrm{h}>300$ км). 
Как видно из рис. 6.2, регион Приамурье и Приморье неоднороден по типу механизмов происходящих здесь землетрясений. В коре региона преобладают пологие надвиги и пологие сбросы (взрезы), т.е. типы сейсмодислокаций, при которых одна из возможных плоскостей механизма очага близка к вертикали, а вторая субгоризонтальна. Среди глубоких событий преобладают сдвиги и взбросо-сдвиги.

Для анализа условий, в которых реализовались землетрясения каталога, был использован метод катакластического анализа (МКА) совокупностей механизмов очагов землетрясений (I этап), реализованный в программном комплексе STRESSseismo [Ребецкий, 1999; Ребецкий, 2003]. Методика позволила построить карты ориентации главных осей тензора напряжений, а также районировать территорию по виду тензора напряжений и геодинамическому режиму, определяемому типом напряженного состояния.

Реконструкция тектонических напряжений в мантии региона. Для МКА очагов землетрясений с гипоцентрами в мантии использовались 52 механизма очагов землетрясений с магнитудой $\mathrm{M}=3.3-7.6$ в диапазоне глубин $\mathrm{h}=306-582$ км (Приложение 2, рис. 6.3).

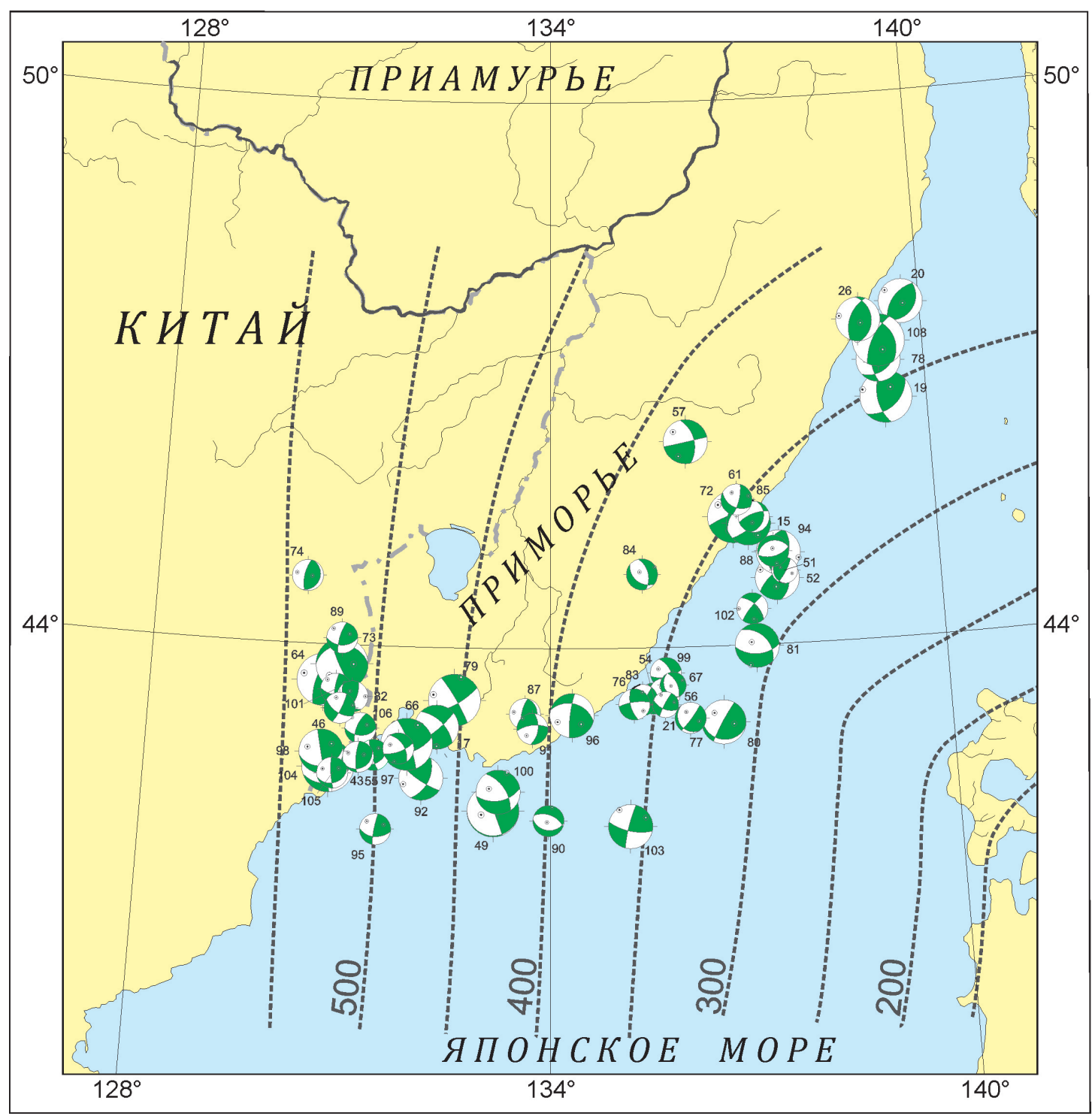

Рис. 6.3. Положение глубоких землетрясений с известными механизмами очагов региона Приамурье и Приморье. Показаны стереограммы механизмов в проекции на нижнюю полусферу, размер пропорционален магнитуде события. Пунктиром показаны изолинии глубин субдукции Тихоокеанской плиты согласно [Zhao, Hasegawa, 1993]. 
Как видно из рис. 6.3, очаги землетрясений группируются вдоль полосы, огибающей побережье Приморья на глубине, понижающейся с 350 км на юго-востоке до 600 км на западе и северо-западе.

Эта область была покрыта равномерной сеткой с шагом $0.23^{\circ}$ по широте и $0.4^{\circ}$ по долготе и 12 км по глубине с погружением на запад в южной части области и на север в северной. Для каждого узла сетки проводился поиск очагов землетрясений, перекрывающих его своей областью упругой разгрузки, размер которой зависит от магнитуды события и может варьироваться. После составления выборка тестировалась на однородность. Для узлов сетки (кластеров) в которых удалось составить однородную выборку механизмов очага, показана ориентация главных осей тензора напряжений, указан тип напряженного состояния и вид тензора напряжения (рис. 6.4, 6.5).

Составление выборок производилось трижды от наиболее строгих условий составления (меньшая область упругой разгрузки, 6-10 механизмов очага в каждой выборке в первой итерации) к менее строгим (большая область упругой разгрузки для 2 итераций, уменьшение до 5 событий в выборке для 3). Результаты расчетов при более строгих условиях имеют более высокий приоритет.

В результате расчетов для всего времени наблюдений в отдельных узлах заданной сетки получены значения тензора современных тектонических напряжений.

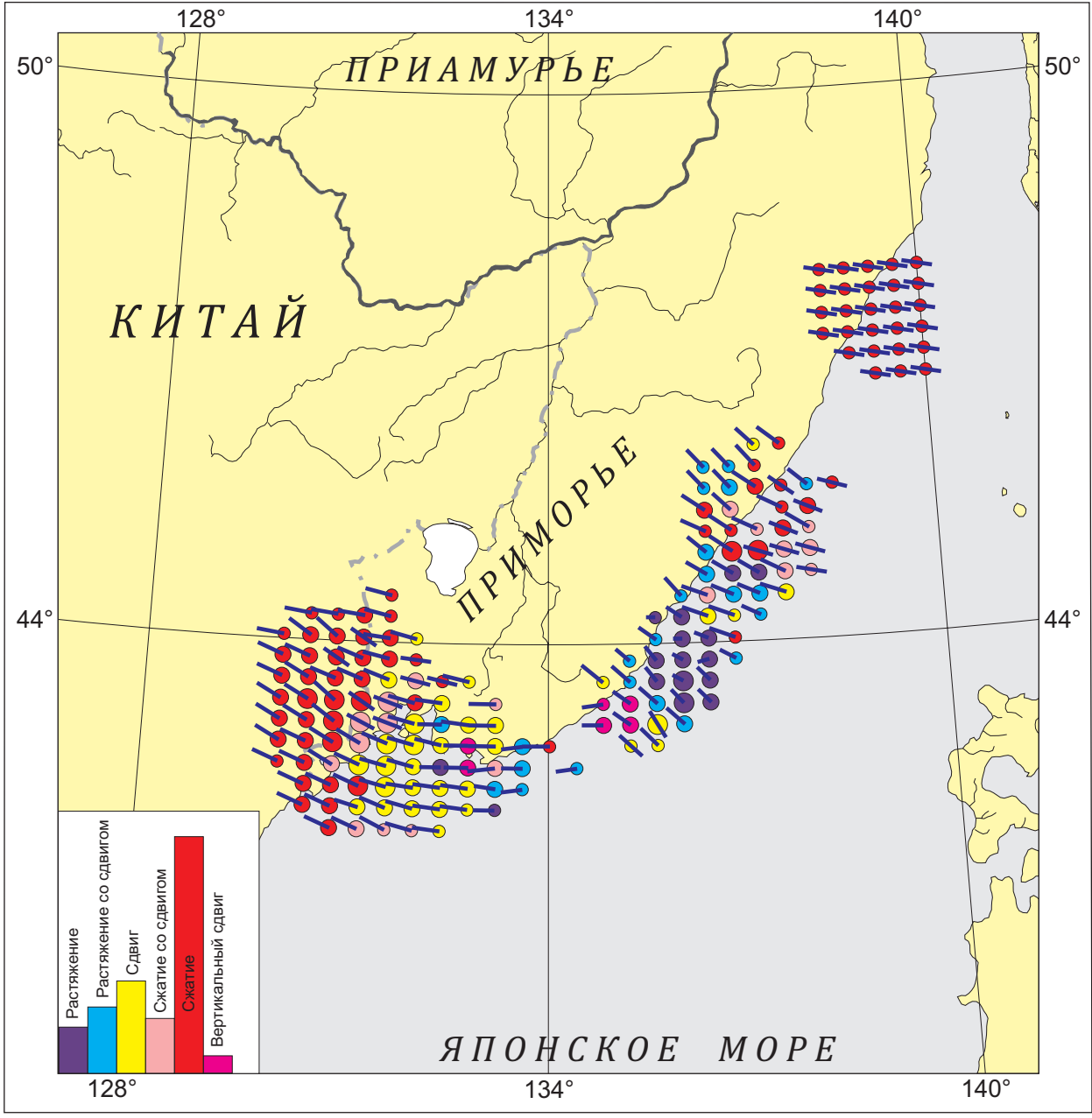

Рис. 6.4. Проекции на горизонтальную плоскость осей главных напряжений $\sigma 3$ (максимальное девиаторное сжатие) и тип напряженного состояния для глубоких землетрясений. Центр окружности соответствует точке, для которой составлена выборка, цвет - типу напряженного состояния, размер пропорционален строгости условий составления выборки. Оси главных напряжений построены в направлении погружения, длина отрезка пропорциональна косинусу угла погружения, при угле погружения менее 19 градусов отрезок пересекает узел. На врезке показано распределение количества узлов по типу напряженного состояния. 


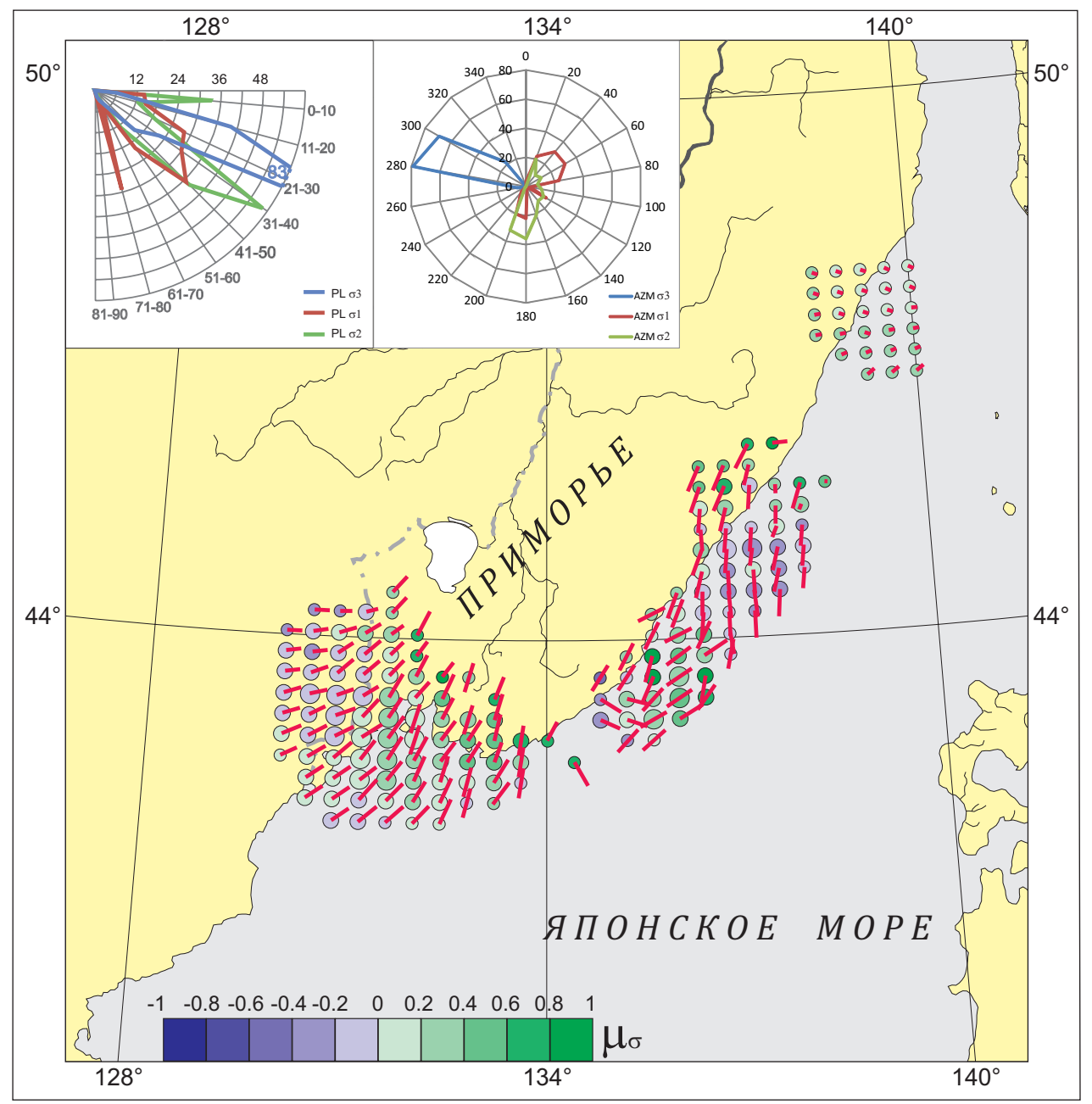

Рис. 6.5. Проекции на горизонтальную плоскость осей главных напряжений $\sigma 1$ (минимальное девиаторное сжатие) и коэффициент Лодэ-Надаи. Центр окружности соответствует точке, для которой составлена выборка, цвет - величине коэффициента Лодэ-Надаи $\mu \sigma$, размер пропорционален строгости условий составления выборки. Оси главных напряжений построены в направлении погружения, длина отрезка пропорциональна косинусу угла погружения, при угле погружения менее 19 градусов отрезок пересекает узел. На врезке показано распределение количества узлов по азимуту и углу погружения главных осей.

Полученные значения напряжений можно охарактеризовать:

- по типу напряженного состояния (по классификации наклона главных осей относительно поверхности, используемой в работах Ю.Л. Ребецкого) [Ребецкий, 1999 и др.]. Классификация в виде октанта главных напряжений показана на рис. 6.6;

- по азимуту и углу погружения главных осей напряжений $\sigma 3$ (сжатия, рис. 6.3) и $\sigma 1$ (растяжения, рис. 6.4);

- по коэффициенту Лодэ-Надаи, определяющему вид тензора напряжений от одноосного растяжения $\mu_{\sigma}=-1$ до одноосного сжатия $\mu_{\sigma}=1$.

Как показано на рисунках выше, в мантии под территорией Приморья удалось полу- чить три группы кластеров, характеризующих напряженно-упругое состояние тектоносферы.

Самый большой юго-западный участок находится в условиях В-3, ЮВ-С3 субгоризонтального $\left(\mathrm{PL}=10-30^{\circ}\right)$ сжатия. Ось растяжения $\sigma 1$ меняет свое направление от довольно крутого восточного падения в западной, наиболее глубокой части участка, до пологого падения и субгоризонтального направления на север на востоке. Это определяет смену напряженного состояния от сжатия на западе до сдвига в восточной части. Вид тензора напряжений на большей части участка близок к чистому сдвигу, т.е. $\mu \sigma \sim 0$, однако на северо-восточной границе $\mu \sigma>0.6$, т.е. здесь преобладает состояние, близкое к одноосному сжатию. 


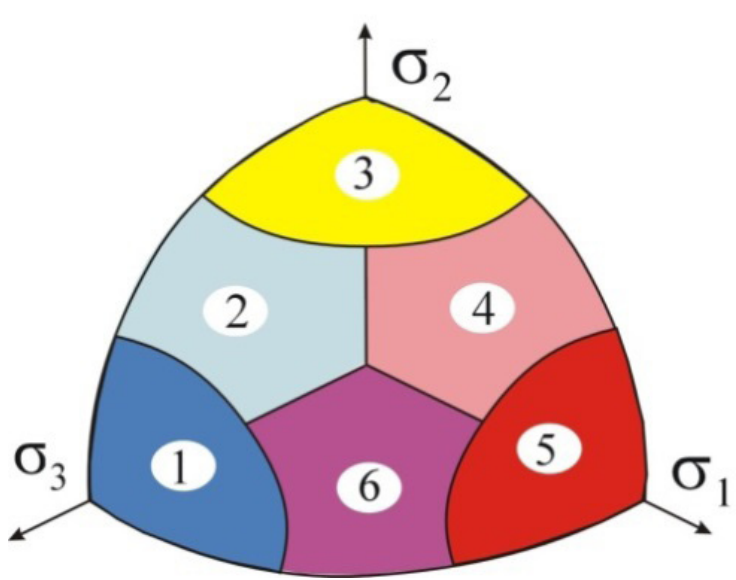

Рис. 6.6. Геодинамический тип напряженного состояния: 1 - режим горизонтального растяжения; 2 - режим горизонтального растяжения со сдвигом; 3 - режим горизонтального сдвига; 4 - режим горизонтального сжатия со сдвигом; 5 - режим горизонтального сжатия; 6 - режима сдвига в вертикальной плоскости (вертикальный сдвиг).

Второй участок северо-восточнее состоит из более разнообразных кластеров. Напряжение сжатия $\sigma 3$ здесь хоть и сохраняет в большей части узлов северо-восточное погружение, но угол погружения меняется в широких пределах от субгоризонтального в восточной части участка до субвертикального в центральной. Ось растяжения б1 еще менее устойчива, хотя в большинстве кластеров преобладают южные и юго-западные направления падения и углы, близкие к горизонту. Это определяет геодинамический тип растяжения в центральной и южной части участка (с элементами сдвига), в северо-восточной части преобладают участки сжатия и сжатия со сдвигом. Вид тензора напряжений существенно изменяется, однако на большей части участка остается в пределах $\mu \sigma=$ \pm 0.6 , несколько узлов с $\mu \sigma>0.6$ встречаются в южной и крайне северной части.

Самый маленький северо-восточный участок составлен всего по 5 близким по типу механизмам очага, потому поле напряжений здесь относительно однородно: горизонтальное ВЮВ-3СЗ сжатие при субвертикальном растяжении. Тип напряженного состояния - сжатие, $\mu \sigma \sim 0$.

Согласно современным представлениям, подтверждаемым данными сейсмической томографии [Fukao at al., 2001; Huang, Zhao, 2006], Тихоокеанская литосферная плита субдуцирует под континент от Курило-Камчатского, Японского, Идзу-Бонинского и Марианского желоба. Мантийная сейсмичность связана с процессами, происходящими в погружающейся плите (слэб). На глубине 500-600 км в переходной зоне верхней мантии плита теряет упругие свойства, сейсмичность в ней прекращается, хотя высокоскоростная структура продолжает прослеживаться в мантии в горизонтальном западном направлении еще на несколько сотен километров. Большая часть вещества, составлявшего слэб, отражается от границы нижней мантии на глубине 660 км, какая-то часть, возможно, погружается через границу.

Полученные данные показывают, что погружающееся в мантию вещество находится в условиях сжатия, направление оси которого близко к направлению погружения, либо образует с ним острый угол (ближе к горизонту). Направление падения оси сжатия - восток-северо-восточное, на наиболее глубоких участках оно близко к направлению сжатия в приповерхностной области контакта литосферных плит в районе глубоководных желобов. Однако направление несколько варьируется на меньшей глубине (второй участок), где проявляется субгоризонтальное растяжение.

На наибольшей глубине, где еще регистрируется сейсмическая активность, наблюдаются условия сокращения площади погружающейся плиты (относительно поверхности), вызванное, вероятно, контактом с границей на глубине 660 км, на меньших глубинах есть участки, где ее проекция на поверхность увеличивается. Возможно, на этом участке проявляется растяжение погружающегося слэба в стороны, что могло бы объяснить столь значительное проникновение сейсмофокальной зоны под континент.

Реконструкция тектонических напряжений в коре региона. Для МКА механизмов очагов землетрясений с гипоцентрами в коре Приамурья и Приморья были использованы данные о 57 событиях (Приложение 2, рис. 6.7). Магнитуды используемых событий находятся в диапазоне $\mathrm{M=3.3-}$ 6.3. Малые магнитуды событий и, как следствие, малые области упругой разгрузки значительно уменьшают возможности их группирования. Распределение известных механизмов очага по площади региона крайне неравномерное, но примерно соответствует уровню сейсмической активности. Так на территории Приморья известен механизм только одного корового события, что делает невозможным подход к анализу тектонических напряжений методом МКА. Наиболее плотно очаги землетрясений с известными механизмами расположены в Янкан-Тукурингра-Джагдинском районе (№ 2), также достаточное для группирования количество событий в Турано-Буреинском районе (№ 4), однако сильные различия в полученных решениях накладывают ограничения на возможность построения однородных выборок. 


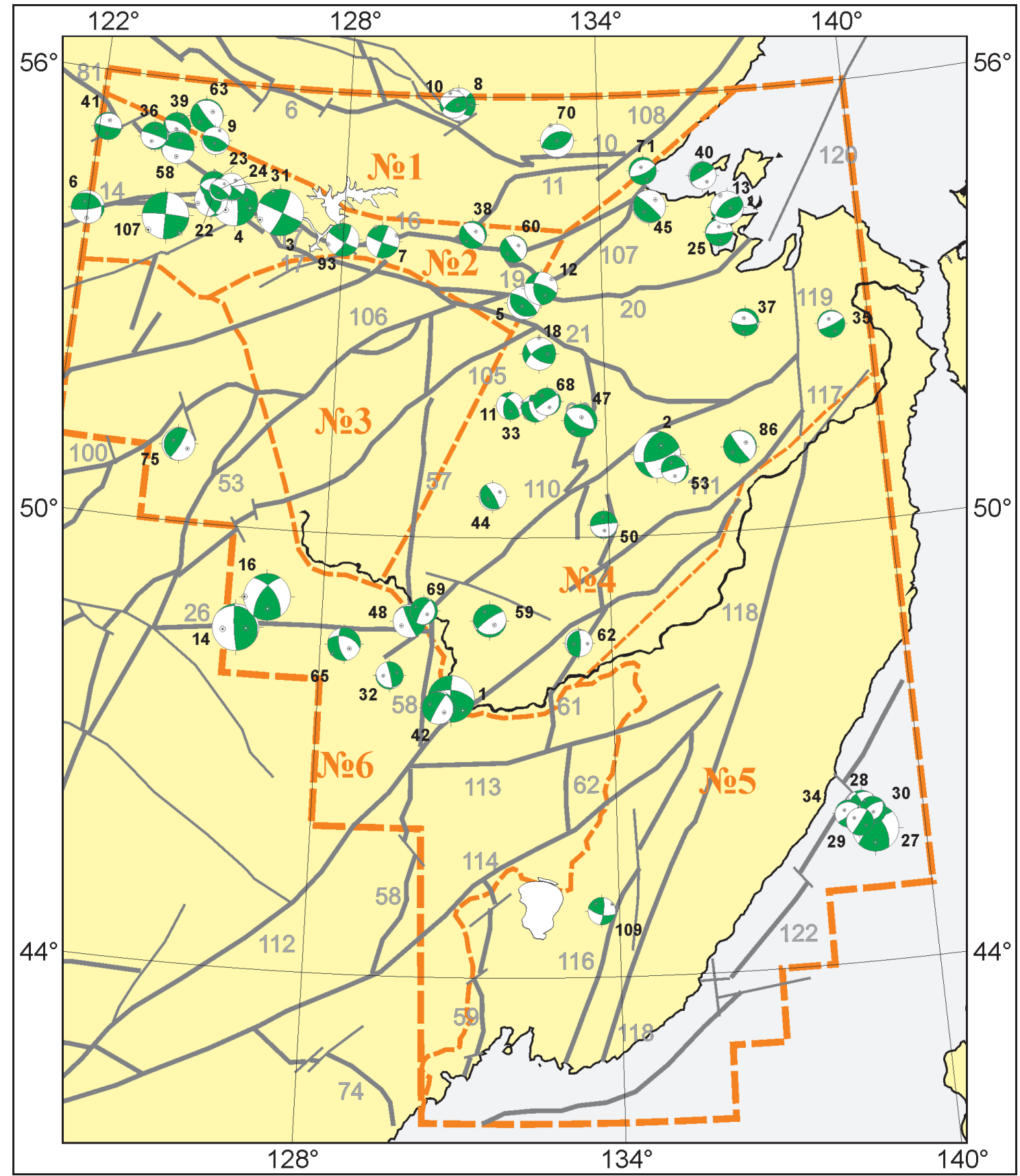

Рис. 6.7. Положение коровых землетрясений с известными механизмами очага региона Приамурье и Приморье. Показаны стереограммы механизмов в проекции на нижнюю полусферу, размер пропорционален магнитуде события. Схема разломной тектоники Приамурья и Приморья построена на основе [Тектоника..., 2004], нумерация разломов приведена согласно гл. 4. 


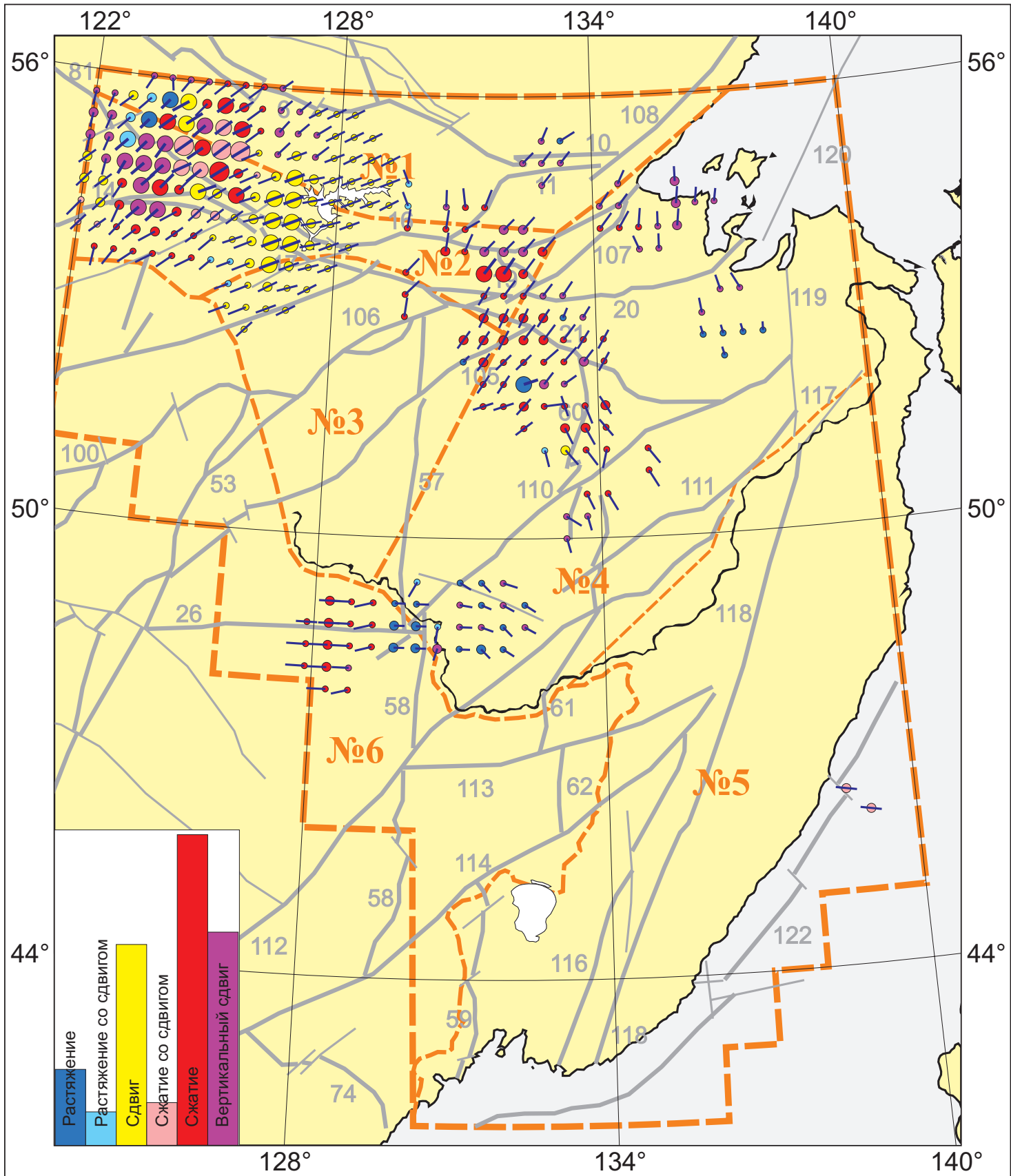

Рис. 6.8. Проекции на горизонтальную плоскость осей главных напряжений $\sigma 3$ (максимальное девиаторное сжатие) и тип напряженного состояния коры региона Приамурье и Приморье. Центр окружности соответствует точке, для которой составлена выборка, цвет - типу напряженного состояния, размер пропорционален строгости условий составления выборки. Оси главных напряжений построены в направлении погружения, длина отрезка пропорциональна косинусу угла погружения, при угле погружения менее 19 градусов отрезок пересекает узел. На врезке показано распределение количества узлов по типу напряженного состояния. Схема разломной тектоники Приамурья и Приморья построена на основе [Тектоника..., 2004], нумерация разломов приведена согласно гл. 4. 


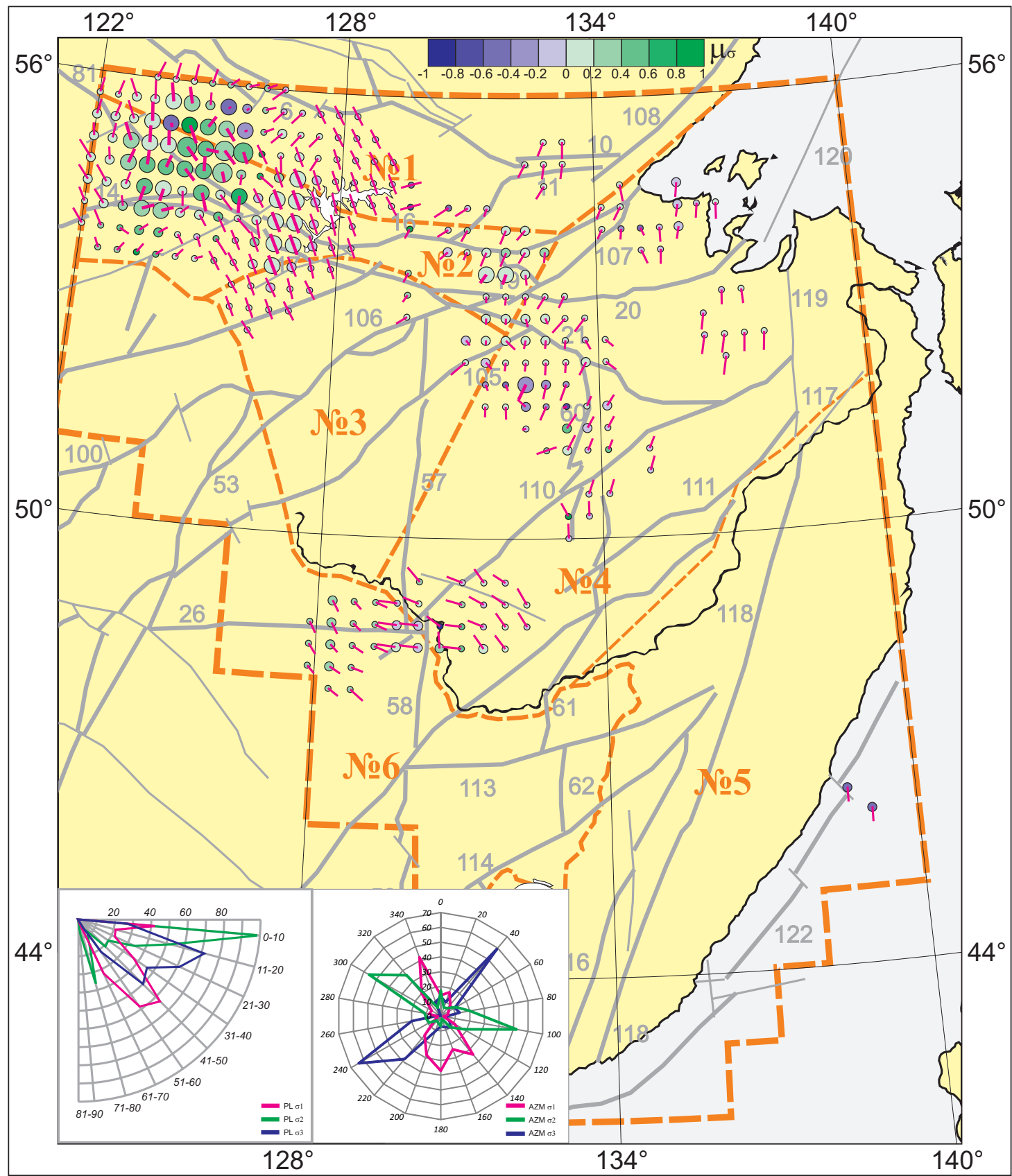

Рис. 6.9. Проекции на горизонтальную плоскость осей главных напряжений $\sigma 1$ (минимальное девиаторное сжатие) и коэффициент Лодэ-Надаи. Центр окружности соответствует точке, для которой составлена выборка, цвет - величине коэффициента Лодэ-Надаи $\mu \sigma$, размер пропорционален строгости условий составления выборки. Оси главных напряжений построены в направлении погружения, длина отрезка пропорциональна косинусу угла погружения, при угле погружения менее 19 градусов отрезок пересекает узел. На врезке показано распределение количества узлов по азимуту и углу погружения главных осей. Схема разломной тектоники Приамурья и Приморья построена на основе [Тектоника..., 2004], нумерация разломов приведена согласно гл. 4. 
Территория региона была покрыта равномерной сеткой с шагом $0.3^{\circ}$ по широте и $0.45^{\circ}$ по долготе с равномерной условной глубиной для всех узлов 20 км.

Процесс составления выборок производился четыре раза со смягчением базовых условий: увеличением области осреднения со 100 км для первой итерации до 150 км для второй и 200 км для четвертой; с уменьшений размера минимальной выборки с 6 событий для 1 итерации до 5 событий для второй и 4 событий для 3 и 4 итераций. Для узлов, в которых удалось составить однородную выборку механизмов очага, показаны ориентации главных осей тензора напряжений, указан тип напряженного состояния и вид тензора напряжения (рис. $6.8,6.9$ ).

Как видно из рисунков, узлы, для которых удалось получить значения напряжений, покрывают значительную территорию, в основном совпадающую с максимумами сейсмической активности (рис. 5.3). Однако наиболее строгие результаты удалось получить только в Верхнем Приамурье (северо-запад региона) и в нескольких узлах на стыке районов № 2 и № 4. Большая часть рассчитанных узлов относится к 4 итерации (самые маленькие окружности). Полученные на этом этапе значения в основном неплохо соотносятся с результатами расчетов при более строгих условиях, а потому, несмотря на слабые начальные условия, тоже могут быть приняты во внимание.

Полученые оценки направления осей региональных напряжений для двух участков северной границы Амурской плиты и Алдано-Станового блока, разделенных зоной сейсмического затишья, примерно совпадают с представлениями, сделанными по единичным механизмам очагов в других работах [Имаев и др., 2003; Ашурков и др., 2011].

В Верхнем Приамурье преобладают условия сдвига и сжатия со сдвигом, т.е. Амурская плита сдвигается относительно АлданоСтанового блока вдоль Южно-Тукурингрского и Северо-Тукурингрского разломов на восток. Вдоль Джелтулакского и западной части СевероТукурингрского разломов происходит надвиг с вертикальным сдвигом, причем условия здесь нестабильны, тип напряженного состояния среды значительно изменяется, что отражается на виде тензора напряжений. Восточнее зоны затишья хр. Джагды расположена область сжатия (укорочения) земной коры, ось сжатия здесь направлена на ССВ. Далее вдоль Монголо-Охотской системы разломов у Охотоморского побережья направле- ние сжатия коры меняется на северное. Здесь, как и в названных выше работах, вдоль северной границы получен постепенный разворот оси сжатия с Ю3-СВ направления на Ю-С. При этом до зоны затишья в районе хребта Джагды на МонголоОхотской системе разломов преобладают условия для сдвиговых деформаций, а после него - условия для деформаций сжатия, что может быть объяснено, например, вращением Алдано-Станового блока независимо от Амурской плиты.

Несколько иначе обстоит дело вдоль разломной зоны Танлу. Сейсмичность здесь диффузна, максимум сейсмической активности не привязан к какому-то одному разлому используемой схемы [Тектоника..., 2004]. Механизмы очага также распределены по площади всего Турано-Буреинского района. Это позволило выявить неоднородности в поле тектонических напряжений как по типу напряженного состояния - выявлены чередующиеся зоны горизонтального сжатия и растяжения, так и по направлению основных осей к востоку от полосы максимальной сейсмической активности напряжение сжатия довольно резко меняет направление на юго-восток и восток. Возможно, на этом участке земной коры Приамурья начинает проявляться влияние океанической субдукции на северную часть Японо-Корейского блока. Еще восточнее в двух узлах, расположенных в Татарском проливе, направление сжатия примерно совпадает с направлением оси горизонтального сжатия в районе контакта океанической плиты с Японской островной дугой [Rebetsky, Polets, 2014].

В работе [Ashurkov et al., 2016] для территории Амурской плиты и ее окраин представлены карты поля скоростей деформации и дилатации, а также количественно оценены скорости максимальных сдвиговых деформаций и направление их осей по данным GPS измерений. Таким образом, есть возможность сравнить полученные по сейсмологическим данным направления тектонических напряжений со скоростями деформаций по данным GPS наблюдений и тип напряженного состояния в коре региона со знаком скорости дилатации.

Интересно, что в районе очаговой зоны Сковородинского землетрясения 2011 г. $(M=6.2)$ в работе [Ashurkov et al., 2016] получена область компрессии к северу от Южно-Тукурингрского разлома и дилатации к югу; в представленном нами варианте сжимающие условия к северу действительно наблюдаются, но южнее растягивающих напряжений нет. Вероятно, это можно объяснить интервалом осреднения: около 50 лет в рассматриваемом случае и только 2-3 года непо- 
средственно после сильнейшего в данном районе события в упомянутой работе. Также следует отметить, что очаг этого события расположен в области неустойчивого типа напряженного состояний коры, т.е. полученная нестабильность может являться следствием подготовки произошедшего в 2011 г. сильного землетрясения. В остальном направление скоростей деформации хорошо согласуются с направлениями полученных осей сжимающего напряжения, учитывая даже некоторый поворот направления к востоку в восточной части данного участка.

Территория самой восточной части Монголо-Охотской разломной зоны, к сожалению, в используемой для сопоставления работе не при- водится ввиду отсутствия там GPS-измерений. Однако можно сравнить две наиболее южных группы узлов в районе Малого Хингана, в восточном из которых условия растяжения совпадают с локальным участком дилатации земной коры, а в западном условия сжатия/взреза попадают на участок компрессии. Направления осей растяжения и сжатия соответственно также хорошо сопоставляются с направлением осей деформации (рис. 2 в [Ashurkov et al., 2016]).

Таким образом, полученная по сейсмологическим данным реконструкция поля тектонических напряжений подтверждает данные расчетов на основе GPS-измерений. 


\section{ЗАКЛЮЧЕНИЕ}

В работе представлена информация о землетрясениях на территории региона Приамурье и Приморье. Дан каталог основных параметров землетрясений, а также сведения, которые могут помочь в интерпретации данных каталога: о состоянии сети сейсмологических наблюдений в различные периоды времени, о ее регистрационных возможностях и оценке представительности полученного на основе этих наблюдений каталога. Авторы постарались сделать каталоги эпицентров землетрясений и механизмов очагов землетрясений наиболее полными и удобным для дальнейшего использования специалистами, представив их как в печатном, так и в электронном виде.

В работе была использована единственная схема разломной тектоники региона по данным монографии [Тектоника..., 2004], хотя, несомненно, возможны и другие варианты интерпертации тектонического и геоморфологического строения региона, в том числе использованные в работах, на которые мы ссылались в соответствующих разделах. Для описания распределения сейсмогенных зон территории региона была использована схема, предложенная Л.С. Оскорбиным в работе [Оскорбин, 1997]. Поскольку нигде, кроме этого сборника трудов, данная схема в таком виде не публиковалась, нам показалось уместным привести ее здесь. Существует также более формализованный вид карты сейсмогенных зон с границами в виде прямых линий [Оскорбин, Бобков, 1997б], наиболее удобной для численного анализа сейсмичности.

Bсе землетрясения каталога совершенно отчетливо разделяются по глубине на коровые (глубиной до 50 км) и мантийные (100 км и более). Поскольку по своей природе они относятся к различным структурам и процессам, не имеет смысл рассматривать их совместно.

Глубокофокусные землетрясения рассматриваемой территории относятся к сейсмофокальным зонам на границе Тихий океан - континент, продолжающимся в направлении Приморья: юго-западному флангу Курило-Камчатской сейс- мофокальной зоны и северо-западному ИдзуБонинской сейсмофокальной зоны. Магнитуда происходящих здесь землетрясений значительно превосходит коровые, но из-за большой глубины макросейсмическое воздействие на поверхность невелико. Зарегистрированный макросейсмический эффект от наиболее сильно проявившегося события 8 апреля 1999 г. не превысил 4 баллов. Полученные при анализе механизмов очагов землетрясений данные показывают, что погружающееся в мантию вещество находится в условиях сжатия, направление оси которого в основном совпадает с направлением погружения либо образует с ним острый угол (ближе к горизонту). В то же время, на значительных участках (кроме самых глубоких) действует близкое к горизонту растягивающее напряжение ортогонально оси погружения.

Распределение коровой сейсмичности по территории региона (рис 5.3, 5.6, 5.8) неравномерно. Наибольшее число землетрясений, в том числе самых сильных, тяготеют к трем сейсмическим поясам: Становому, в зоне влияния восточного фланга одноименного разлома; ЯнканТукурингра-Соктаханскому на восточном фланге Монголо-Охотского линеамента; Турано-Селемджинскому, протягивающемуся от Малого Хингана на север. Впрочем, весь обширный Турано-Буреинский район довольно сейсмически активен и, возможно, после реализации нескольких сильных землетрясений, максимумы сейсмической активности в его восточной части также сложатся в продолжение сейсмического пояса вдоль диагональных разломов системы Танлу.

Наименее сейсмически активными районами являются Зейско-Селемджинский, за исключением северной его части; центральная часть Сихотэ-Алинского района - сильные землетрясения здесь тяготеют к периферии. Сейсмичность Центрального Сихотэ-Алинского разлома проявляется довольно слабо. Продолжается сейсмическое затишье в районе хр. Джагды. 
Сейсмичность южного Приморья, наиболее населенной части региона, можно охарактеризовать как слабую, наиболее сильные землетрясения происходили здесь в 1962-1967 годах. Однако даже относительно слабые события вызывали здесь значительный макросейсмический эффект.

Временной ход сейсмического процесса в регионе в целом достаточно равномерный на протяжении, по крайней мере, последних 45 лет (рис. 5.5), самые заметные кратковременные активизации происходили в 1986, 1990 и 2011 годах.

Реально зарегистрированные в населенных пунктах региона макросейсмические проявления не превышали 7-8 баллов по шкале МСК-64. Чаще всего землетрясения со значительным макросейсмическим эффектом происходят в Верхнем Приамурье - наиболее сейсмически активном районе и в Южном Приморье - наиболее густонаселенном районе.

C тектонической позиции Приамурье и Приморье расположено на Амурской литосферной плите. В работе получены оценки направления осей региональных напряжений для двух участков северной границы Амурской плиты и Алдано-Станового блока (рис 6.8, 6.9), разделенных зоной сейсмического затишья. В Верхнем Приамурье преобладают условия сдвига и сжатия со сдвигом, т.е. Амурская плита сдвигается относительно Алдано-Станового блока вдоль Южно-
Тукурингрского и Северо-Тукурингрского разломов на восток, вдоль Джелтулакского и западной части Северо-Тукурингрского разломов происходит надвиг со сдвигом. Восточнее зоны затишья хр. Джагды расположена область сжатия (укорочения) земной коры, ось сжатия здесь направлена на ССВ. Далее вдоль Монголо-Охотской системы разломов у Охотоморского побережья направление сжатия коры меняется на северное. Несколько иначе обстоит дело вдоль разломной зоны Танлу. Сейсмичность здесь диффузна, максимумы сейсмической активности не привязаны к какому-то одному разлому используемой схемы [Тектоника..., 2004].

Анализ механизмов очагов землетрясений Турано-Буреинского района позволил выявить неоднородности в поле тектонических напряжений как по типу напряженного состояния - выявлено чередование зон растяжения и сжатия, так и по направлению основных осей - к востоку от полосы максимальной сейсмической активности напряжение сжатия довольно резко меняет направление на юг, юго-восток и восток.

Для изучения столь обширного и сложного региона необходимо большее число инструментальных данных, их получение в обозримый срок невозможно без развития сети сейсмологических наблюдений и качественного изменения применяемых к составлению каталогов методов. 


\section{СПИСОК ЛИТЕРАТУРНЫХ ИСТОЧНИКОВ}

Аптекман Ж.Я., Желанкина Т.С., Писаренко В.Ф. и др. Массовое определение механизмов очагов землетрясений на ЭВМ // Вычислительная сейсмология. Вып. 12: Теория и анализ сейсмических наблюдений. М.: Наука, 1979. С. 45-58.

Аргентов В.В., Гнибиденко Г.С., Попов А.А., Потапьев С.В. Глубинное строение Приморья (по данным ГСЗ). М.: Наука, 1976. 90 с.

Ашурков С.В., Саньков В.А., Мирошниченко А.И., Лухнев А.В., Сорокин А.П., Серов М.А., Бызов Л.М. Кинематика Амурской плиты по данным GPS-геодезии // Геология и геофизика. 2011. T. 52 (2). C. 299-311.

Балакина Л.М. Цунами и механизм очага землетрясений северо-западной части Тихого океана // Труды СахКНИИ. Вып. 29: Волны цунами. ЮжноСахалинск, 1972. С. 48-72.

Бобков А.О. Автоматизированный комплекс для обработки землетрясений с гипоцентрами в земной коре // Сейсмологические наблюдения на Дальнем Востоке CCCP. М., 1989. C. 55-66.

Бормотов В.А., Войтенок Л.А. Закономерности миграций землетрясений Приамурья // Тихоокеан. геология. 1998. Т. 17, № 2. С. 51-60.

Бельтенев Е.Б. Разрывная тектоника восточного сектора региона БАМ и ее влияние на размещение оруденения // Разломы и эндогенное оруденение БайкалоАмурского региона. М., 1982. С. 73-88.

Бурде А.И., Неволин Л.А., Соловьев В.О. Даубихинский разлом // Советская геология. 1963. № 5. C. $129-132$.

Быкова В.В., Татевосян Р.Э., Николаев Л.Д. и др. Сковородинское землетрясение 2011 г. // Физика Земли. 2015. № 1. C. 112-127

Видовский К.И., Козьмин Б.М., Николаев В.В. и др. Огоронское землетрясение 16 августа 1977 г.// Землетрясения в СССР в 1977 году. М.: Наука, 1981. C. 88-91.

Волкова Л.Ф., Поплавская Л.Н., Соловьева О.Н. Шкалы MPVA, MSHA для определения магнитуд близких глубокофокусных землетрясений Дальнего Востока // Сейсмологические наблюдения на Дальнем Востоке СССР. Методические работы ЕССН. М.: Наука, 1989. С. 81-85.

Воскресенский С.С., Леонтьев О.К., Спиридонов О.И. и др. Геоморфологическое районирование СССР и прилегающих морей. М.: Высш. школа, 1980. 343 с.
Гатинский Ю.Г., Рундквист Д.В. Геодинамика Евразии - тектоника плит и тектоника блоков // Геотектоника. 2004. № 1. С. 3-20.

Голенецкий С.И. Землетрясения Прибайкалья // Землетрясения СССР в 1976 году. М.: Наука, 1980. C. $46-57$.

Гутенберг Б., Рихтер К.Ф. Магнитуда, интенсивность, энергия и ускорение как параметры землетрясений (II) // Слабые землетрясения. М.: ИЛ, 1961. C. $72-119$.

Даммер А.Э. Дальневосточная зона сейсмичности // Вопросы географии Дальнего Востока. Сб. 9. Хабаровск, 1971. С. 104-114.

Диденко А.Н., Зазаров В.С., Гильманова Г.З. и др. Формализованный анализ коровой сейсмичности Сихотэ-Алинского орогена и прилегающих территорий // Тихоокеан. геология. 2017. Т. 36, № 2. С. $58-69$.

Долгих Г.И., Долгих С.Г., Чебров В.Н., Шевченко Ю.В. Геофизический полигон «Мыс Шульца» // Вестник ДВО РАН. 2010. № 5. С. 165-169.

Зоненшайн Л.П., Савостин Л.А., Мишарина Л.А., Солоненко Н.В. Геодинамика Байкальской рифтовой зоны и тектоника плит внутренней Азии // Геолого-геофизические и подводные исследования озера Байкал. М.: ИО АН СССР, 1979. С. 157-211.

Иванов Б.А. Центральный Сихотэ-Алинский разлом. Владивосток: Дальневост. кн. изд-во, 1972. 423 с.

Ивашинников Ю.К. О палеографическом значении Хорольско-Гайворонского хребта в прогнозе минеральных ресурсов Ханканской впадины / Тез. V совещ. географов Сибири и Дальнего Востока. Вып. 1, ч. 1.1973.

Имаев В.С., Имаева Л.П., Козьмин Б.М., Николаев В.В., Семенов Р.М. Буферные сейсмогенные структуры между Евразийской и Амурской литосферными плитами на юге Сибири // Тихоокеан. геология. 2003. Т. 22, № 6. С. 55-61.

Имаева Л.П., Имаев В.С., Козьмин Б.М. Сейсмогеодинамика Алдано-Станового блока // Тихоокеан. геология. 2012. Т. 31, № 1. С. 5-17.

Ким Чун Ун, Андреева М.Ю. Каталог землетрясений Курило-Камчатского региона (1737-2005 гг.). Препринт. Южно-Сахалинск: ИМГиГ ДВО РАН, 2009. $126 \mathrm{c}$

Караулов В.Б., Ставцев А.Л. О главных системах разломов материковой части Дальнего Востока // Геотектоника. 1975. № 4. С. 71-81. 
Коваленко Н.С., Фокина Т.А., Сафонов Д.А. Приамурье и Приморье // Землетрясения Северной Евразии, 2004 год. Обнинск: ГС РАН, 2010. С. 164-172.

Коваленко Н.С., Фокина Т.А., Сафонов Д.А. Приамурье и Приморье // Землетрясения Северной Евразии, 2007 год. Обнинск: ГС РАН, 2013. С. 170-181.

Коваленко Н.С., Фокина Т.А., Сафонов Д.А. Приморье и Приамурье // Землетрясения Северной Евразии, 2008 год. Обнинск: ГС РАН, 2015. С. 200-203.

Козьмин Б.М., Емельянов Н.П., Емельянова Э.А. и др. Сильные землетрясения Якутии // Землетрясения СССР в 1971 г. М.: Наука, 1975. С. 133-141.

Козьмин Б.М., Андреев Т.А., Дарешкина Н.М., Югова Р.С. Землетрясения Якутии и Северо-Востока // Землетрясения СССР в 1972 г. М.: Наука, 1976. C. 119-313.

Кондорская Н.В., Горбунова И.В., Киреев И.А., Вандышева Н.В. О составлении унифицированного каталога сильных землетрясений Северной Евразии по инструментальным данным (1901-1990 гг.) // Сейсмичность и сейсмическое районирование Северной Евразии. М.: ИФЗ РАН, 1993. Вып. 1. С. 76.

Кондорская Н.В., Соловьев С.Л. Общее состояние вопроса определения магнитуды и энергетической классификации землетрясений в практике сейсмологических наблюдений // Магнитуда и энергетическая классификация землетрясений. М., 1974. № 1. C. $13-42$.

Кондорская Н.В., Федорова И.В. Сейсмические станции «Единой системы сейсмологических наблюдений СССР». М.: ОИФЗ РАН, 1996. 36 c.

Коновалов А.В., Нагорных Т.В., Сафонов Д.А. Современные исследования механизмов очагов землетрясений о. Сахалин / отв. ред. А.И. Кожурин. Владивосток: Дальнаука, 2014. 252 с.

Красный Л.И. Геология региона Байкало-Амурской магистрали. М.: Изд-во АН СССР, 1963. 464 с.

Леонов Н.Н., Берсенев И.И., Гришкян Р.И. и др. Сейсмическое районирование Приморья и Приамурья // Сейсмическое районирование Курильских островов, Приморья и Приамурья. Владивосток: ДВНЦ АН CCCP. 1977. С 143-156.

Малышев Ю.Ф., Подгорный В.Я., Шевченко Б.Ф., Романовский Н.П., Каплун В.Б., Горнов П.Ю. Глубинное строение структур ограничения Амурской литосферной плиты // Тихоокеан. геология. 2007. T. 26, № 2. C. 3-17.

Мирошников Л.Д. О сейсмичности Приморья // Изв. Всесоюз. Геогр. о-ва. 1974. № 6. С. 471-476.

Мушкетов И.В., Орлов А.П. Каталог землетрясений Российской империи // Зап. Рус. геогр. об-ва. Т. 26. СПб., 1893. 582 с.

Нагорных Т.В., Поплавская Л.М. Методические основы и результаты построения карт представительности землетрясений Сахалина, Приморья и Приамурья с гипоцентрами в земной коре Приморья // Проблемы сейсмичности Дальнего Востока и Восточной Сибири: Докл. международ. науч. симпоз., ЮжноСахалинск, 24-28 сентября 2002 г. Т. 2. Южно-Сахалинск: Институт морской геологии и геофизики ДВО РАН, 2003. С. 156-173.

Николаев В.В., Семенов Р.М., Солоненко В.П. Сейсмогеология Монголо-Охотского линеамента (восточный фланг). Новосибирск: Наука, 1979. 113 с.
Николаев В.В., Семенов Р.М., Солоненко В.П. Сейсмотектоника, вулканы и сейсмическое районирование хребта Станового. Новосибирск: Наука, Сиб. отдние, $1982.220 \mathrm{c}$.

Николаев В.В., Семенов Р.М., Оскорбин Л.С., Карсаков Л.П., Малышев Ю.Ф., Онухов Ф.С., Ставров В.Н. Сейсмотектоника и сейсмическое районирование Приамурья. Новосибирск: Наука, Сиб. отд-ние, 1989. 128 с

Николаев В.В., Семенов Р.М., Козьмин Б.М., Имаев В.С. Сильное землетрясение на юге Якутии 20 (21).04.1989 г. // Тихоокеан. геология. 1996. Т. 15, № 1. C. $120-128$.

Новый каталог сильных землетрясений на территории СССР с древнейших времен до 1975 г. / Под ред. Н.В. Кондорской, Н.В. Шебалина. М.: Наука, 1977. $535 \mathrm{c}$.

Овсюченко А.Н., Мараханов А.В., Вакарчук Р.Н., Ларьков А.С., Новиков С.С., Рогожин Е.А. Геологические и макросейсмические проявления землетрясения 16 октября 2011 г. в Сковородинском районе Амурской области // Вопросы инженерной сейсмологии. 2012. Т. 39, № 4. С 5-18.

Олейников А.В., Олейников Н.А. Палеосейсмология. Владивосток: Дальнаука. 2009. 164 с.

Органов М.Г. Новые данные о сейсмичности Приморского края. В помощь производству (Дальневосточ. политехнич. ин-т). № 2. Владивосток, 1962а. C. $117-118$.

Органов М.Г. Сейсмческое микрорайонирование территории города Находки // Тез. докл. на сессии учен. сов. Дальневост. науч.-исслед. ин-та по строит. по итогам науч. исслед. 1961 г. Владивосток, 19626. С. 6-8.

Органова Н.М., Кручинина Л.М. Геолого - геофизические условия сейсмичности в юго-западной части Приморья // Сов. геология. 1978. № 12. С. 122-124.

Органова Н.М. О прогнозе сейсмичности Приморья // Климоморфогенез и региональный географический прогноз ДВНЦ АН СССР. Владивосток, 1980. C. $151-168$.

Оскорбин, Л.С., Волкова Л.Ф., Савосько В.Н. Баджальское землетрясение 29 августа 1970 г. // Вопросы сейсмичности Сибири. Часть II: Сейсмичность, сейсмогеология, сейсмический режим, механизмов очагов землетрясений. Новосибирск, 1972. С. 38-42.

Оскорбин Л.С., Поплавская Л.Н. Ванинские землетрясения сентября - октября 1968 г. // Землетрясения в СССР в 1968 году. М.: Наука, 1972. С. 184-186.

Оскорбин Л.С., Волкова Л.Ф., Савосько В.Н. Баджальское землетрясение 29 августа 1970 г. // Землетрясения в СССР в 1970 году. М.: Наука, 1973. C. 200-203.

Оскорбин Л.С., Волкова Л.Ф., Хантаев А.М. Землетрясения Сахалина // Землетрясения в СССР в 1973 году. М.: Наука, 1976. С. 153-161.

Оскорбин Л.С. Сейсмичность Приморья // Сейсмическое районирование Курильских островов, Приморья и Приамурья. Владивосток, 1977. С. 128-142.

Оскорбин Л.С., Козьмин Б.М., Семенов Р.М., Николаев В.В.. Землетрясения Приамурья и Приморья // Землетрясения в СССР в 1980 году. М.: Наука, 1983. C. $70-76$. 
Оскорбин Л.С., Соловьева О.Н. Номограмма для оперативного определения магнитуды близких землетрясений по объемным волнам, записанным сейсмографами с механической регистрацией // Теория и оперативный прогноз цунами. М.: Наука, 1980. C. $107-111$.

Оскорбин Л.С., Шолохова А.А., Рудик М.И. Землетрясения Приамурья и Приморья // Землетрясения в СССР в 1983 году. М.: Наука, 1986. С. 75-79.

Оскорбин Л.С. Районирование Юга Дальнего Востока по сейсмогенным зонам // Проблемы сейсмической опасности Дальневосточного региона. ЮжноСахалинск: Институт морской геологии и геофизики ДВО РАН, 1997. С. 111-153. (Геодинамика тектоносферы зоны сочленения Тихого океана с Евразией. Том VI).

Оскорбин Л.С., Бобков А.О. Макросейсмические проявления землетрясений на территории южно части Дальнего Востока // Проблемы сейсмической опасности Дальневосточного региона. ЮжноСахалинск: Институт морской геологии и геофизики ДВО РАН, 1997а. С. 45-74. (Геодинамика тектоносферы зоны сочленения Тихого океана с Евразией. Том VI)

Оскорбин Л.С., Бобков А.О. Сейсмический режим сейсмогенных зон юга Дальнего Востока // Проблемы сейсмической опасности Дальневосточного региона. Южно-Сахалинск: Институт морской геологии и геофизики ДВО РАН, 1997б. С. 179-197. (Геодинамика тектоносферы зоны сочленения Тихого океана с Евразией. Том VI).

Парфенов Л.М., Козьмин Б.М., Имаев В.С. и др. Геодинамика Олекмо-Становой сейсмической зоны. Якутск: ЯФ СО АН СССР, 1985. 136 с.

Парфенов Л.М., Козьмин Б.М., Гриненко О.В. и др. Сейсмичность и геодинамика Восточной Сибири // Современная тектоническая активность Земли и сейсмичность. М.: Наука, 1987. С. 108-129.

Парфенов Л.М., Берзин Н.А., Ханчук А.И., Бадарч Г., Беличенко В.Г., Булгатов А.Н., Дриль С.И., Кириллова Г.Л., Кузьмин М.И., Ноклеберг У., Прокопьев А.В., Тимофеев В.Ф., Томуртогоо О., Янь Х. Модель формирования орогенных поясов Центральной и Северо-Восточной Азии // Тихоокеан. геология. 2003. Т. 22, № 6. С. 7-41.

Поплавская Л.Н., Оскорбин Л.С., Волкова Л.Ф., Бойчук А.Н. Землетрясения Дальнего Востока // Землетрясения в СССР в 1967 году. М.: Наука, 1970. C. $150-188$.

Поплавская Л.Н., Бобков А.О., Кузнецова В.Н. и др. Принципы формирования и состав алгоритмического обеспечения регионального центра обработки сейсмологических наблюдений (на примере Дальнего Востока) // Сейсмологические наблюдения на Дальнем Востоке СССР. М., 1989. С. 32-51

Поплавская Л.Н., Шолохова А.А., Рудик Н.А. и др. Приморское землетрясение 13 ноября 1990 г. // Землетрясения в СССР в 1990 году. М.: Наука, 1996. C. $75-79$.

Поплавская Л.Н., Нагорных Т.В., Рудик М.И. Методика и первые результаты массовых определений механизмов очагов коровых землетрясений Дальнего Востока // Землетрясения Северной Евразии в 1995 году. М.: ГС РАН, 2001. С. 95-99.
Попов В.В. Каталог землетрясений на территории СССР (с 1908 по 1936 г. включительно). Вып. ІІ: Сибирь / отв. ред. П.М. Никифоров. Труды сеймол. ин-та АН СССР. 1939. № 89.38 c.

Раутиан Т.Г. Об определении энергии землетрясений на расстоянии до 3000 км // Экспериментальная сейсмика. М.: Наука, 1964. С.88-93. (Труды ИФЗ АН CСCР. №32(199))

Ребецкий Ю.Л. Методы реконструкции тектонических напряжений и сейсмотектонических деформаций на основе современной теории пластичности // Докл. АН. 1999. т. 365, № 3. С. 392-395.

Ребецкий Ю.Л. Развитие метода катакластического анализа сколов для оценки величин тектонических напряжений // Докл. АН. 2003. Т. 388, № 2. С. 237-241.

Ризниченко Ю.В. Метод суммирования землетрясений для изучения сейсмической активности // Изв. АН СССР. Сер. геофиз. 1964. № 7. С. 969-977.

Салун С.А. Тектоника и история развития Сихотэ-Алинской геосинклинальной складчатой системы. М.: Недра, 1978. 183 с.

Степашко А.А. Глубинные основы сейсмотектоники Дальнего Востока: Приамурская и Приморская зоны // Тихоокеан. геология. 2011. Т. 30, №1. С. 3-15.

Сейсмическое районирование территории СССР. Методические основы и региональное описание карты 1978 г. / отв. ред. В.И. Бунэ, Г.П. Горшков. М.: Наука, 1980. $308 \mathrm{c}$

Семенов Р.М., Авдеев В.А. Зейское землетрясение 2 ноября 1973 г. // Результаты научных исследований Института земной коры в 1973 г. Иркутск, 1974. C. $108-111$.

Семенов Р.М., Николаев В.В. О связи сейсмичности с неотектоникой Тукурингра-Джагдинского поднятия // Геология и геофизика. 1977. № 4. С. 68-76.

Семенов Р.М., Николаев В.В. К прогнозу сейсмичности в восточной части Монголо-Охотского сейсмического пояса // Докл. АН. 1991. Т. 320, № 2. С. 417-420.

Семенов Р.М. Причины сейсмического молчания хребта Джагды (Дальний Восток) и его потенциальная сейсмическая опасность // Докл. АН. 1993. Т. 333, № 5. C. $648-649$.

Солоненко В.П., Николаев В.В., Семенов Р.М., Демьянович М.Г., Курушин Р.А., Хромовских В.С., Чипизубов А.В. Геология и сейсмичность зоны БАМ. Сейсмогеология и сейсмическое районирование. 1985. $192 \mathrm{c}$

Спирин А.И., Левин Ю.Н. Сейсмическая станция «Южно-Сахалинск». 60 лет отечественным инструментальным сейсмологическим наблюдениям на Сахалине. Южно-Сахалинск-Обнинск: ГС РАН, 2008. $32 \mathrm{c}$.

Старовойт О.Е., Мишаткин В.Н. Сейсмические станции Российской Академии наук (состояние на 2001 г.). Москва-Обнинск, 2001. 86 с.

Тараканов Р.З., Ким Чун Ун, Сухомлинова Р.И. Строение Курильской фокальной зоны // Сейсмическое районирование Курильских островов, Приморья и Приамурья. Владивосток: ДВНЦ АН СССР, 1977. C. $6-16$. 
Тектоника, глубинное строение и минерагения Приамурья и сопредельных территорий / отв. ред. Г.А. Шатков, А.С. Вольский. СПб.: Изд-во ВСЕГЕИ, 2004. $190 \mathrm{c}$.

Тектоническая карта Дальнего Востока и сопредельных регионов (на формационной основе) / гл. ред.: Ю.А. Косыгин, Л.М. Парфенов. 1:2000000. М.: АН СССР, Мингео СССР, 1978.

Токарева T.А. Анализ достоверности решения задачи об эпицентре с помощью автоматизированного комплекса (АК) «САХАЛИН» // Актуальные вопросы геологии, геофизики и биологии: Материалы XII конференции молодых ученых ИМГиГ ДВО РАН. Южно-Сахалинск, 1991. С. 77-92.

Уланов А.С. К материалам по сейсмологии Дальнего Востока // Известия Дальневосточного Геофизического Института. Вып. II (IX). Владивосток, 1932. C. $147-163$.

Уломов В.И., Шумилина Л.С. Комплект карт общего сейсмического районирования территории Российской Федерации - ОСР-97. Масштаб 1:8 000000. Объяснительная записка и список городов и населенных пунктов, расположенных в сейсмоопасных районах. М.: Изд-во ОИФЗ РАН, 1999. 57 с.

Урбан Н.А., Поплавская Л.Н., Токарева Т.А. и др. Землетрясения Сахалина // Землетрясения в СССР в 1990 году. М.: Наука, 1996. С. 79-87.

Уфимцев Г.Ф. Тектонический анализ рельефа (на примере востока СССР). Новосибирск: Наука, 1984. 182 с.

Фокина Т.А., Коваленко Н.С., Паршина И.А., Рудик М.И., Сафонов Д.А. Приморье и Приамурье // Землетрясения Северной Евразии в 1999 г. Обнинск: ФОП, 2005. С. 140-147.

Фокина Т.А., Коваленко Н.С., Рудик М.И., Сафонов Д.А. Приморье и Приамурье // Землетрясения Северной Евразии в 2002 году. Обнинск: ГС РАН, 2008. С. 196-199.

Фокина Т.А., Коваленко Н.С., Рудик М.И., Сафонов Д.А. Приамурье и Приморье // Землетрясения Северной Евразии в 2003 году. Обнинск: ГС РАН, 2009. С. 159-165.

Ханчук А.И., Коновалов А.В., Сорокин А.А. и др. Инструментальное и информационно-технологическое обеспечение сейсмологических наблюдений на Дальнем Востоке России // Вестник ДВО РАН. 2011. № 3. С. 127-137.

Ханчук А.И., Сафонов Д.А., Радзиминович Я.Б. и др. Сильнейшее современное землетрясение в верхнем Приамурье 14 октября 2011 года: Первые результаты комплексного исследования // Докл. АН. 2012. T. 445, № 3. С. 338-341.

Харахинов В.В., Гальцев-Безюк С.Д., Терещенков А.А. Разломы Сахалина // Тихоокеан. геология. 1984. № 2. C. $77-86$.

Чермных Г.П. Землетрясение в Приморском крае 15 августа 1967 г. // Землетрясения в СССР в 1968 году. М.: Наука, 1972. С. 186-188.

Шерман С.И., Леви К.Г., Ружич В.В., Саньков В.А., Днепровский Ю.И., Рассказов С.В. Геология и сейсмичность зоны БАМ. Неотектоника. Новосибирск: Наука, 1984. 207 с.
Шестаков Н.В., Сафонов Д.А., Коваленко Н.С., Касаткин С.А., Краснопеев С.М., Герасименко М.Д., Meng Guojie. Результаты исследования Приморского землетрясения 12 апреля 2014 года, $\mathrm{M}=4.5$ (Дальний Восток России) // Тихоокеан. геология. 2018. T. 37, № 1. С. 51-60.

Шолохова А.А., Оскорбин Л.С., Рудик М.И. Землетрясения Приамурья и Приморья // Землетрясения в СССР в 1986 г. М.: Наука, 1989. С. 122-125.

Шолохова А.А., Оскорбин Л.С., Рудик М.И. и др. Землетрясения Приамурья и Приморья // Землетрясения в СССР в 1987 году. М.: Наука, 1990. С. 86-89.

Шолохова А.А., Оскорбин Л.С., Рудик М.И. Землетрясения Приамурья и Приморья // Землетрясения в СССР в 1988 г. М.: Наука, 1991. С. 127-129.

Ashurkov S.V., San'kov V.A., Serov M.A. Luk'yanov P.Y., Grib N.N., Bordonskii G.S. \& Dembelov M.G. Evaluation of present-day deformations in the Amurian Plate and its surroundings, based on GPS data // Rus. Geol. Geophys. 2016. Vol. 57(11). P. 1626-1634.

DeMets C., Gordon R.G., Argus D.F. Geologically current plate motions // Geophys. J. Int. 2010. Vol. 181. P. 1-80.

Benioff H. Earthquakes and rock creep // Bull. Seismol. Soc. Amer. 1951. Vol. 41, № 1. P. 31-62.

Bird P. An updated digital model of plate boundaries // Geochem. Geophys. Geosyst. 2003. Vol. 4. 1027. doi:10.1029/2001GC000252, 3

Fukao Y., Widiyantoro S., Obayashi M. Stagnant slabs in the upper and lower mantle transition region // Rev. Geophys. 2001. Vol. 39, № 3. C. 291-323.

Huang J., Zhao D. High-resolution mantle tomography of China and surrounding regions // J. Geophys. Res.: Solid Earth. 2006. Vol. 111. B09305.

Mackey K.G., Fujita K., Gounbina L.V., Koz'min B.M., Imaev V.S., Imaeva L.P., Sedov B.M. Explosion contamination of the Northeast Siberian seismicity catalog: implication for natural earthquake distributions and location of the Tanlu Fault in Russian // Bull. Seismol. Soc. Amer. 2003. Vol. 93, № 2. P. 737-746.

Petit C., Fournier M. Present-day velocity and stress fi elds of the Amurian plate from thin-shell fi niteelement modeling // Geophys. J. Int. 2005. Vol. 160. P. 357-369.

Rebetsky Yu.L., Polets A.Yu. The state of stresses of the lithosphere in Japan before the catastrophic Tohoku earthquake of 11 March 2011 // Geodynamics \& Tectonophysics. 2014. Vol. 5 (2). P. 469-506.

Wei D., Seno T. Determination of the Amurian plate motion // Mantle Dynamics and Plate Interactions in East Asia. Geodyn. Series. 1998. Vol. 27. P. 337-346.

Zhao D., Hasegawa A. P wave tomographic imaging of the crust and upper mantle beneath the Japan Islands // J. Geophys. Res.: Solid Earth. 1993. Vol. 98. № B3. P. 4333-4353

Zhao D., Hasegawa A., Kanamori H. Deep structure of Japan subduction zone as derived from local, regional, and teleseismic events // J. Geophys. Res.: Solid Earth. 1994. Vol. 98, № B11. P. 22313-22329.

Zonenshain L.P., Savostin L.A. Geodynamics of the Baikal rift zone and plate tectonics of Asia // Tectonophysics. 1981. Vol. 76. P. 1-45. 
Приложение 
Приложение 1А. Каталог землетрясений региона Приамурье и Приморье 1865-2015 гг. магнитудой М $\geq 3.3$.

\begin{tabular}{|c|c|c|c|c|c|c|c|c|c|c|c|}
\hline № & & Іата & & & $t_{0}$ & & Эпи & нтр & $h$ & & \\
\hline$\Pi / \Pi$ & $\Gamma$ & $\mathrm{M}$ & д & ч & мин & $\mathrm{c}$ & $\varphi^{\circ}, \mathrm{N}$ & $\lambda^{\circ}, \mathrm{E}$ & км & $M / M L H$ & $K \mathrm{p}$ \\
\hline 1 & 1865 & 6 & 27 & 17 & 20 & & 53.20 & 139.00 & $10-40$ & 4.4 & 11.9 \\
\hline 2 & 1867 & 6 & 24 & 5 & 12 & & 43.40 & 133.30 & $3-30$ & 3.7 & 10.7 \\
\hline 3 & 1883 & 8 & 3 & & & & 48.30 & 134.80 & 5-20 & 3.7 & 10.7 \\
\hline 4 & 1884 & 1 & 2 & 4 & 51 & & 53.20 & 139.00 & $10-40$ & 4.4 & 11.9 \\
\hline 5 & 1888 & 8 & 23 & & & & 50.00 & 134.00 & $15-20$ & 5.5 & 13.9 \\
\hline 6 & 1888 & 10 & 4 & 6 & 15 & & 47.80 & 131.10 & $5-20$ & 5.0 & 13.0 \\
\hline 7 & 1889 & 2 & 18 & & & & 54.30 & 127.70 & $7-30$ & 4.2 & 11.6 \\
\hline 8 & 1895 & 7 & 14 & 6 & 59 & & 51.70 & 140.50 & $5-50$ & 4.2 & 11.6 \\
\hline 9 & 1902 & 7 & 3 & 15 & 36 & 45 & 43.20 & 129.60 & $10-40$ & 6.6 & 15.9 \\
\hline 10 & 1904 & 5 & 25 & 19 & 26 & & 50.20 & 137.00 & $7-30$ & 4.7 & 12.5 \\
\hline 11 & 1905 & 8 & 25 & 9 & 46 & 45 & 43.00 & 129.00 & 470 & 6.8 & \\
\hline 12 & 1907 & 10 & 3 & 12 & 9 & & 48.70 & 132.20 & $11-44$ & 5.2 & 13.4 \\
\hline 13 & 1911 & 8 & 6 & 14 & 39 & 10 & 53.50 & 127.10 & $5-20$ & 5.0 & 13.0 \\
\hline 14 & 1911 & 9 & 6 & 12 & 54 & 12 & 47.50 & 134.80 & 5-20 & 3.4 & 10.1 \\
\hline 15 & 1912 & 9 & 10 & 20 & 20 & & 54.20 & 121.70 & $7-30$ & 4.1 & 11.4 \\
\hline 16 & 1913 & 1 & 19 & 17 & 40 & & 53.40 & 121.60 & $7-30$ & 4.1 & 11.4 \\
\hline 17 & 1913 & 8 & 26 & & & & 53.80 & 121.20 & $7-30$ & 4.1 & 11.4 \\
\hline 18 & 1914 & 12 & 23 & 6 & 7 & & 52.50 & 139.80 & $12-50$ & 6.0 & 14.8 \\
\hline 19 & 1917 & 7 & 31 & 3 & 23 & 10 & 42.50 & 131.00 & 460 & 7.5 & \\
\hline 20 & 1918 & 1 & 30 & 21 & 18 & 30 & 48.20 & 131.20 & $5-20$ & 5.0 & 13.0 \\
\hline 21 & 1918 & 1 & 30 & 21 & 19 & 50 & 47.80 & 131.50 & $5-20$ & 5.0 & 13.0 \\
\hline 22 & 1918 & 1 & 30 & 21 & 18 & 37 & 45.40 & 136.50 & 350 & 7.7 & \\
\hline 23 & 1918 & 2 & 9 & 20 & 46 & 26 & 43.00 & 130.00 & 450 & 6.6 & \\
\hline 24 & 1918 & 4 & 10 & 2 & 3 & 53 & 43.50 & 130.90 & 550 & 7.2 & \\
\hline 25 & 1918 & 6 & 8 & 0 & 0 & & 47.90 & 130.90 & 15 & 4.7 & 12.5 \\
\hline 26 & 1919 & 2 & 14 & 23 & 9 & 20 & 47.50 & 129.00 & 15 & 4.7 & 12.5 \\
\hline 27 & 1920 & 5 & 6 & 9 & 40 & 30 & 44.00 & 131.00 & 520 & 5.9 & \\
\hline 28 & 1921 & 5 & 4 & 4 & 53 & 30 & 45.00 & 135.00 & 300 & 5.3 & \\
\hline 29 & 1923 & 1 & 27 & 2 & & & 52.30 & 129.60 & $5-50$ & 4.0 & 11.2 \\
\hline 30 & 1923 & 10 & 15 & 0 & 0 & & 48.50 & 122.50 & 15 & 5.0 & 13.0 \\
\hline 31 & 1924 & 2 & 24 & 16 & 46 & 3 & 44.20 & 138.20 & 320 & 5.4 & \\
\hline 32 & 1924 & 3 & 11 & 14 & 40 & 36 & 51.20 & 139.70 & $10-40$ & 5.6 & 14.1 \\
\hline 33 & 1924 & 3 & 13 & 10 & 32 & 30 & 44.00 & 138.00 & 360 & 5.0 & \\
\hline 34 & 1924 & 11 & 25 & 17 & 27 & 30 & 53.40 & 141.30 & $7-30$ & 5.3 & 13.5 \\
\hline 35 & 1926 & 10 & 19 & 14 & 5 & & 43.60 & 135.60 & 114 & 5.5 & 13.9 \\
\hline 36 & 1926 & 10 & 28 & 0 & 0 & & 48.00 & 122.70 & 15 & 5.0 & 13.0 \\
\hline 37 & 1926 & 11 & 8 & 11 & 5 & & 48.10 & 130.00 & $7-30$ & 3.4 & 10.1 \\
\hline 38 & 1926 & 11 & 19 & & & & 47.80 & 131.00 & 5-20 & 3.3 & 9.9 \\
\hline 39 & 1926 & 11 & 26 & & & & 48.30 & 135.00 & $5-20$ & 3.3 & 9.9 \\
\hline 40 & 1926 & 12 & 19 & 9 & 53 & & 48.00 & 130.00 & $5-20$ & 4.0 & 11.2 \\
\hline 41 & 1927 & 5 & 17 & 21 & 44 & 23 & 42.80 & 131.00 & 560 & 6.2 & \\
\hline 42 & 1927 & 6 & 10 & 18 & 13 & 30 & 47.30 & 139.80 & $5-50$ & 5.0 & 13.0 \\
\hline 43 & 1927 & 11 & 18 & 20 & 2 & 50 & 54.50 & 122.50 & $10-40$ & 4.8 & 12.7 \\
\hline
\end{tabular}


Приложение 1А. Каталог землетрясений региона Приамурье и Приморье 1865-2015 гг. магнитудой М $\geq 3.3$.

\begin{tabular}{|c|c|c|c|c|c|c|c|c|c|c|c|}
\hline № & & Іата & & & $t_{0}$ & & Эпи & нтр & $h$ & & \\
\hline$\Pi / \Pi$ & $\Gamma$ & $\mathrm{M}$ & д & ч & мин & $\mathrm{c}$ & $\varphi^{\circ}, \mathrm{N}$ & $\lambda^{\circ}, \mathrm{E}$ & км & $M / M L H$ & $K \mathrm{p}$ \\
\hline 44 & 1928 & 6 & 7 & 6 & 24 & 41 & 43.40 & 132.00 & 570 & 6.0 & \\
\hline 45 & 1929 & 2 & 1 & 21 & 24 & & 53.20 & 141.00 & 15 & 4.4 & 11.9 \\
\hline 46 & 1929 & 9 & 21 & 8 & 30 & & 53.10 & 125.70 & $10-40$ & 4.4 & 11.9 \\
\hline 47 & 1931 & 2 & 20 & 5 & 33 & 25 & 44.70 & 135.50 & 350 & 7.3 & \\
\hline 48 & 1931 & 6 & 30 & 4 & 22 & 42 & 48.50 & 123.50 & 15 & 5.2 & \\
\hline 49 & 1931 & 9 & 17 & 19 & 30 & & 50.10 & 127.00 & $50-120$ & 5.5 & \\
\hline 50 & 1932 & 11 & 13 & 4 & 46 & 58 & 43.90 & 136.50 & 310 & 7.3 & \\
\hline 51 & 1933 & 7 & 14 & 16 & 3 & 36 & 43.80 & 132.50 & 500 & 5.5 & \\
\hline 52 & 1933 & 7 & 24 & 8 & 37 & 56 & 42.50 & 132.00 & 560 & 6.5 & \\
\hline 53 & 1933 & 9 & 9 & 5 & 2 & 31 & 45.40 & 131.50 & 600 & 6.4 & \\
\hline 54 & 1933 & 9 & 19 & 4 & 46 & 30 & 43.20 & 133.00 & 8 & 4.5 & 11.0 \\
\hline 55 & 1934 & 9 & 1 & 6 & 55 & 19 & 45.10 & 137.00 & 300 & 5.5 & \\
\hline 56 & 1934 & 9 & 1 & 15 & 56 & & 44.00 & 137.20 & 400 & 5.4 & \\
\hline 57 & 1935 & 3 & 28 & 23 & 47 & 51 & 43.50 & 131.90 & 560 & 6.2 & \\
\hline 58 & 1937 & 1 & 24 & 16 & 12 & 44 & 56.00 & 130.00 & 16 & 5.2 & 13.4 \\
\hline 59 & 1937 & 4 & 29 & 20 & 18 & 57 & 45.70 & 137.30 & 380 & 6.7 & \\
\hline 60 & 1938 & 7 & 31 & 21 & 54 & 14 & 43.00 & 136.80 & 360 & 6.0 & \\
\hline 61 & 1938 & 10 & 21 & 6 & 46 & 23 & 43.00 & 131.80 & 560 & 6.2 & \\
\hline 62 & 1939 & 1 & 22 & 4 & 41 & 4 & 55.00 & 132.00 & 20 & 5.5 & 13.9 \\
\hline 63 & 1940 & 7 & 10 & 5 & 49 & 53 & 43.60 & 131.00 & 580 & 7.3 & \\
\hline 64 & 1940 & 11 & 22 & 13 & 6 & 40 & 44.00 & 132.00 & 560 & 6.0 & \\
\hline 65 & 1942 & 7 & & & & & 51.90 & 132.10 & $5-30$ & 4.5 & 11.0 \\
\hline 66 & 1942 & 9 & 1 & 18 & 59 & 35 & 48.50 & 128.00 & 20 & 5.7 & 14.2 \\
\hline 67 & 1944 & 10 & 14 & 15 & 15 & 30 & 46.30 & 137.00 & 460 & 6.0 & \\
\hline 68 & 1946 & 1 & 11 & 1 & 33 & 32 & 45.00 & 130.60 & 580 & 7.2 & \\
\hline 69 & 1948 & 12 & 23 & 15 & 31 & 11 & 44.90 & 130.40 & 15 & 5.2 & 13.4 \\
\hline 70 & 1949 & 4 & 5 & 9 & 27 & 7 & 41.60 & 131.60 & 570 & 6.5 & \\
\hline 71 & 1950 & 12 & 10 & 12 & 41 & 10 & 43.60 & 132.50 & $7-28$ & 4.1 & \\
\hline 72 & 1952 & 7 & 8 & 0 & 59 & 23 & 42.00 & 131.00 & 600 & 5.3 & \\
\hline 73 & 1952 & 11 & 5 & 14 & 11 & & 44.50 & 138.00 & 320 & 4.5 & \\
\hline 74 & 1955 & 9 & 14 & 5 & & & 43.00 & 131.60 & 6 & 4.4 & 11.9 \\
\hline 75 & 1956 & 4 & 9 & 2 & 15 & 40 & 49.00 & 130.50 & 20 & 5.0 & 13.0 \\
\hline 76 & 1956 & 10 & 14 & 0 & 39 & 1 & 48.50 & 122.00 & 5 & 5.2 & 13.4 \\
\hline 77 & 1957 & 1 & 3 & 12 & 48 & 27.8 & 43.95 & 130.61 & 570 & 7.4 & \\
\hline 78 & 1957 & 1 & 3 & 13 & 43 & 33 & 43.87 & 130.60 & 560 & 5.6 & \\
\hline 79 & 1957 & 5 & 13 & 2 & 20 & 59 & 42.80 & 136.60 & 350 & 5.3 & \\
\hline 80 & 1957 & 10 & 9 & 18 & 33 & 50 & 51.50 & 132.80 & 20 & 4.3 & 11.7 \\
\hline 81 & 1958 & 2 & 13 & 9 & 32 & 27 & 43.50 & 135.80 & 360 & 5.1 & \\
\hline 82 & 1958 & 11 & 24 & 12 & & & 42.50 & 135.00 & 300 & 4.8 & \\
\hline 83 & 1959 & 3 & 29 & 19 & 9 & 35 & 45.07 & 137.20 & 330 & 6.1 & \\
\hline 84 & 1959 & 6 & 7 & 17 & 39 & 0 & 47.90 & 135.50 & 20 & 4.3 & 11.7 \\
\hline 85 & 1959 & 10 & 29 & 14 & 30 & 25 & 42.86 & 131.06 & 535 & 6.7 & \\
\hline 86 & 1959 & 10 & 31 & 17 & 1 & 14 & 44.00 & 137.50 & 300 & 4.7 & \\
\hline
\end{tabular}


Приложение 1А. Каталог землетрясений региона Приамурье и Приморье 1865-2015 гг. магнитудой М $\geq 3.3$.

\begin{tabular}{|c|c|c|c|c|c|c|c|c|c|c|c|}
\hline № & & Қата & & & $t_{0}$ & & Эпг & нтр & $h$ & & \\
\hline$\Pi / \Pi$ & $\Gamma$ & $\mathrm{M}$ & д & ч & мин & $\mathrm{c}$ & $\varphi^{\circ}, \mathrm{N}$ & $\lambda^{\circ}, \mathrm{E}$ & км & $M / M L H$ & $K \mathrm{p}$ \\
\hline 87 & 1960 & 7 & 2 & 12 & 44 & 22 & 41.32 & 131.96 & 530 & 6.2 & \\
\hline 88 & 1960 & 8 & 10 & 1 & 34 & 4 & 54.00 & 133.00 & 15 & 4.5 & 11.0 \\
\hline 89 & 1961 & 7 & 25 & 18 & 41 & 37 & 41.70 & 137.70 & 180 & 4.6 & \\
\hline 90 & 1961 & 10 & 3 & 12 & 58 & 13 & 54.40 & 122.70 & 20 & 3.3 & 10.0 \\
\hline 91 & 1961 & 11 & 30 & 7 & 54 & 34 & 54.30 & 121.00 & 15 & 4.0 & 11.0 \\
\hline 92 & 1961 & 11 & 30 & 12 & 20 & 7 & 43.80 & 132.10 & 469 & 4.7 & \\
\hline 93 & 1961 & 12 & 3 & 19 & 55 & 6 & 43.40 & 135.20 & 400 & 5.5 & \\
\hline 94 & 1962 & 1 & 28 & 16 & 34 & 44 & 54.70 & 124.20 & 15 & 3.3 & 10.0 \\
\hline 95 & 1962 & 1 & 30 & 5 & 52 & 17 & 55.00 & 124.50 & 15 & 3.3 & 10.0 \\
\hline 97 & 1962 & 5 & 20 & 23 & 45 & 24 & 55.60 & 129.60 & 20 & 4.0 & 11.0 \\
\hline 98 & 1962 & 7 & 16 & 16 & 59 & 4 & 55.90 & 128.30 & 15 & 4.0 & 11.0 \\
\hline 99 & 1962 & 8 & 8 & 16 & 38 & 9 & 54.30 & 126.00 & 20 & 4.0 & 11.0 \\
\hline 100 & 1962 & 8 & 9 & 13 & 55 & 56 & 54.90 & 125.90 & 20 & 4.0 & 11.0 \\
\hline 101 & 1962 & 8 & 15 & 10 & 6 & 55 & 45.10 & 133.10 & 30 & 5.0 & 13.0 \\
\hline 103 & 1962 & 9 & 2 & 11 & 21 & 7 & 54.30 & 124.40 & 15 & 4.0 & 11.0 \\
\hline 104 & 1962 & 9 & 2 & 11 & 22 & 9 & 54.80 & 124.90 & 15 & 4.0 & 11.0 \\
\hline 107 & 1963 & 4 & 23 & 12 & 52 & 56 & 54.90 & 125.20 & 15 & 3.3 & 10.0 \\
\hline 108 & 1963 & 6 & 16 & 2 & 53 & 25 & 44.40 & 135.60 & 450 & 4.6 & \\
\hline 109 & 1963 & 6 & 21 & 13 & 44 & 24 & 47.80 & 130.70 & 20 & 5.5 & 13.9 \\
\hline 110 & 1963 & 8 & 16 & 21 & 59 & 56 & 54.50 & 136.30 & 15 & 4.4 & 12.0 \\
\hline 114 & 1964 & 1 & 2 & 14 & 28 & 43 & 54.10 & 127.70 & 15 & 4.0 & 11.0 \\
\hline 116 & 1964 & 5 & 16 & 17 & 26 & 28 & 42.10 & 132.70 & 550 & 4.7 & \\
\hline 118 & 1964 & 7 & 13 & 20 & 10 & 48 & 55.90 & 134.10 & 15 & 4.4 & 12.0 \\
\hline 120 & 1964 & 8 & 30 & 18 & 57 & 34 & 56.00 & 124.80 & 15 & 3.3 & 10.0 \\
\hline 121 & 1964 & 9 & 24 & 12 & 15 & 3 & 53.30 & 121.00 & 15 & 4.5 & 12.1 \\
\hline 122 & 1964 & 10 & 17 & 6 & 34 & 49.3 & 42.43 & 130.88 & 502 & 4.5 & \\
\hline 126 & 1965 & 1 & 2 & 7 & 37 & 37 & 55.50 & 130.60 & 15 & 3.3 & 10.0 \\
\hline 127 & 1965 & 1 & 3 & 4 & 33 & 5 & 55.70 & 130.50 & 15 & 3.3 & 10.0 \\
\hline 129 & 1965 & 2 & 21 & 21 & 13 & 45 & 55.50 & 123.10 & 15 & 3.3 & 10.0 \\
\hline 130 & 1965 & 2 & 25 & 3 & 5 & 34 & 42.56 & 135.28 & 337 & 4.5 & \\
\hline 131 & 1965 & 3 & 10 & 13 & 22 & 28 & 54.80 & 123.20 & 15 & 4.3 & 11.8 \\
\hline 132 & 1965 & 6 & 12 & 6 & 19 & 20 & 42.01 & 131.40 & 484 & 4.5 & \\
\hline 133 & 1965 & 8 & 13 & 17 & 36 & 8 & 55.20 & 134.70 & 15 & 4.4 & 12.0 \\
\hline 134 & 1965 & 12 & 6 & 7 & 55 & 9.1 & 43.42 & 134.04 & 422 & 4.8 & \\
\hline 135 & 1965 & 12 & 24 & 3 & 21 & 31 & 55.70 & 130.80 & 15 & 4.0 & 11.2 \\
\hline 136 & 1965 & 12 & 30 & 23 & 18 & 2 & 54.20 & 127.70 & 15 & 3.3 & 10.0 \\
\hline 137 & 1966 & 2 & 7 & 18 & 12 & 10 & 54.00 & 128.50 & 15 & 4.0 & 11.2 \\
\hline 138 & 1966 & 2 & 14 & 1 & 18 & 48 & 54.80 & 123.60 & 15 & 3.3 & 10.0 \\
\hline 139 & 1966 & 3 & 13 & 21 & 28 & 36 & 55.90 & 125.90 & 15 & 3.3 & 10.0 \\
\hline 142 & 1966 & 4 & 23 & 1 & 1 & 8 & 53.50 & 125.00 & 15 & 3.3 & 10.0 \\
\hline 143 & 1966 & 6 & 30 & 8 & 59 & 49.5 & 43.40 & 132.41 & 476 & 5.2 & \\
\hline 145 & 1966 & 10 & 2 & 14 & 22 & 20.0 & 53.50 & 123.90 & 15 & 3.3 & 10.0 \\
\hline 146 & 1966 & 11 & 20 & 12 & 29 & 27.0 & 54.50 & 123.60 & 15 & 3.3 & 10.0 \\
\hline
\end{tabular}


Приложение 1А. Каталог землетрясений региона Приамурье и Приморье 1865-2015 гг. магнитудой М $\geq 3.3$.

\begin{tabular}{|c|c|c|c|c|c|c|c|c|c|c|c|}
\hline \multirow{2}{*}{ 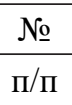 } & \multicolumn{3}{|c|}{ Дата } & \multicolumn{3}{|c|}{$t_{0}$} & \multicolumn{2}{|c|}{ Эпицентр } & \multirow{2}{*}{$\begin{array}{c}h \\
\text { км }\end{array}$} & \multirow[b]{2}{*}{$M / M L H$} & \multirow[b]{2}{*}{$K \mathrm{p}$} \\
\hline & $\Gamma$ & $\mathrm{M}$ & д & ч & Мин & $\mathrm{c}$ & $\varphi^{\circ}, \mathrm{N}$ & $\lambda^{\circ}, \mathrm{E}$ & & & \\
\hline 147 & 1967 & 1 & 10 & 21 & 3 & 21.0 & 53.80 & 127.40 & 15 & 3.3 & 10.0 \\
\hline 148 & 1967 & 2 & 14 & 11 & 56 & 35.0 & 55.60 & 130.30 & 15 & 3.3 & 10.0 \\
\hline 149 & 1967 & 2 & 25 & 0 & 18 & 37.0 & 43.40 & 139.20 & 225 & 4.3 & 11.8 \\
\hline 150 & 1967 & 3 & 13 & 2 & 37 & 27.0 & 44.00 & 133.00 & 33 & 4.7 & 12.4 \\
\hline 151 & 1967 & 3 & 16 & 18 & 1 & 56.5 & 42.41 & 137.20 & 290 & 4.6 & \\
\hline 152 & 1967 & 4 & 24 & 15 & 12 & 51.0 & 42.40 & 131.20 & 527 & 4.4 & \\
\hline 154 & 1967 & 5 & 6 & 19 & 48 & 32.0 & 43.10 & 139.00 & 20 & 4.7 & 12.5 \\
\hline 156 & 1967 & 5 & 21 & 13 & 27 & 15.0 & 55.80 & 123.60 & 15 & 3.3 & 10.0 \\
\hline 157 & 1967 & 5 & 28 & 23 & 5 & 16.0 & 54.10 & 128.60 & 15 & 3.3 & 10.0 \\
\hline 158 & 1967 & 6 & 14 & 3 & 46 & 19.4 & 45.39 & 136.84 & 345 & 4.9 & \\
\hline 159 & 1967 & 8 & 15 & 15 & 36 & 6.0 & 44.70 & 132.30 & $7-15$ & 5.0 & 13.0 \\
\hline 160 & 1967 & 8 & 15 & 17 & 41 & 49.0 & 42.90 & 133.90 & 20 & 5.0 & 13.0 \\
\hline 161 & 1967 & 8 & 17 & 12 & 28 & 5.0 & 44.70 & 132.30 & $5-20$ & 3.8 & 10.8 \\
\hline 162 & 1967 & 8 & 28 & 6 & 18 & 3.0 & 54.30 & 127.20 & 15 & 4.0 & 11.2 \\
\hline 164 & 1967 & 11 & 12 & 2 & 24 & 59.0 & 55.10 & 123.20 & 15 & 3.3 & 10.0 \\
\hline 167 & 1968 & 1 & 7 & 7 & 42 & 5.0 & 43.20 & 134.40 & 416 & 4.1 & \\
\hline 168 & 1968 & 2 & 26 & 5 & 30 & 57.0 & 43.66 & 132.10 & 414 & 4.4 & \\
\hline 169 & 1968 & 4 & 11 & 6 & 46 & 28.9 & 42.38 & 130.97 & 535 & 4.9 & \\
\hline 170 & 1968 & 5 & 9 & 6 & 4 & 33.0 & 54.10 & 122.10 & 15 & 4.4 & 12.0 \\
\hline 172 & 1968 & 5 & 31 & 20 & 24 & 40.0 & 48.50 & 140.60 & 10 & 4.0 & 11.2 \\
\hline 173 & 1968 & 6 & 11 & 16 & 16 & 3.0 & 44.90 & 137.10 & 30 & 4.0 & 11.2 \\
\hline 174 & 1968 & 6 & 14 & 1 & 15 & 57.7 & 42.58 & 132.67 & 469 & 4.4 & \\
\hline 175 & 1968 & 8 & 24 & 0 & 44 & 35.0 & 55.70 & 127.50 & 15 & 3.3 & 10.0 \\
\hline 176 & 1968 & 9 & 19 & 4 & 57 & 40.0 & 49.10 & 140.30 & 22 & 4.8 & 12.7 \\
\hline 177 & 1968 & 9 & 19 & 5 & 1 & 16.0 & 49.40 & 140.40 & 22 & 5.0 & 13.0 \\
\hline 178 & 1968 & 9 & 19 & 5 & 22 & 51.0 & 49.20 & 140.30 & 30 & 4.4 & 12.0 \\
\hline 182 & 1968 & 9 & 19 & 14 & 36 & 53.0 & 54.20 & 134.50 & 15 & 3.3 & 10.0 \\
\hline 183 & 1968 & 9 & 19 & 21 & 17 & 19.0 & 49.20 & 140.30 & 30 & 4.4 & 10.1 \\
\hline 184 & 1968 & 9 & 21 & 11 & 45 & 3.5 & 49.10 & 140.50 & 10 & 3.6 & 10.8 \\
\hline 185 & 1968 & 9 & 22 & 15 & 26 & 1.0 & 49.10 & 140.50 & 10 & 3.6 & 10.5 \\
\hline 186 & 1968 & 9 & 24 & 19 & 30 & 27.0 & 49.20 & 140.20 & 30 & 4.2 & 11.7 \\
\hline 187 & 1968 & 9 & 24 & 21 & 40 & 54.0 & 49.30 & 140.60 & $0-5$ & 3.7 & 10.7 \\
\hline 189 & 1968 & 9 & 26 & 5 & 37 & 26.0 & 49.50 & 138.70 & 30 & 3.7 & 10.7 \\
\hline 190 & 1968 & 9 & 28 & 4 & 11 & 22.0 & 49.30 & 140.20 & 30 & 4.2 & 11.8 \\
\hline 191 & 1968 & 10 & 13 & 21 & 53 & 36.0 & 49.20 & 140.50 & 30 & 4.7 & 12.5 \\
\hline 192 & 1968 & 10 & 18 & 12 & 47 & 38.0 & 49.20 & 140.50 & 10 & 3.4 & 10.1 \\
\hline 196 & 1968 & 12 & 29 & 16 & 9 & 34.0 & 55.80 & 140.70 & 20 & 4.0 & 11.2 \\
\hline 198 & 1969 & 1 & 18 & 17 & 9 & 31.0 & 55.50 & 122.70 & 15 & 3.3 & 10.0 \\
\hline 199 & 1969 & 2 & 3 & 0 & 17 & 9.0 & 56.10 & 140.00 & 15 & 3.3 & 10.0 \\
\hline 208 & 1969 & 4 & 10 & 14 & 54 & 3.7 & 42.10 & 131.06 & 560 & 6.8 & \\
\hline 211 & 1969 & 4 & 30 & 18 & 41 & 38.0 & 55.70 & 122.80 & 15 & 3.3 & 10.0 \\
\hline 212 & 1969 & 6 & 6 & 12 & 52 & 15.0 & 53.40 & 138.10 & 15 & 4.0 & 11.0 \\
\hline 214 & 1969 & 6 & 26 & 15 & 46 & 34.2 & 42.40 & 131.04 & 542 & 4.7 & \\
\hline
\end{tabular}


Приложение 1А. Каталог землетрясений региона Приамурье и Приморье 1865-2015 гг. магнитудой М $\geq 3.3$.

\begin{tabular}{|c|c|c|c|c|c|c|c|c|c|c|c|}
\hline № & \multicolumn{3}{|c|}{ Дата } & \multicolumn{3}{|c|}{$t_{0}$} & \multicolumn{2}{|c|}{ Эпицентр } & \multirow{2}{*}{$\begin{array}{c}\frac{h}{\text { Км }} \\
\text { K }\end{array}$} & \multirow[b]{2}{*}{$M / M L H$} & \multirow[b]{2}{*}{$K \mathrm{p}$} \\
\hline$\Pi / \Pi$ & $\Gamma$ & $\mathrm{M}$ & д & ч & мин & c & $\varphi^{\circ}, \mathrm{N}$ & $\lambda^{\circ}, \mathrm{E}$ & & & \\
\hline 215 & 1969 & 7 & 8 & 17 & 8 & 46.2 & 43.26 & 135.47 & 370 & 4.5 & \\
\hline 218 & 1969 & 9 & 20 & 12 & 27 & 30.0 & 54.60 & 125.40 & 15 & 4.4 & 12.0 \\
\hline 221 & 1969 & 11 & 19 & 8 & 45 & 4.7 & 41.83 & 133.82 & 437 & 4.9 & \\
\hline 226 & 1970 & 2 & 19 & 13 & 3 & 59.0 & 54.70 & 133.80 & 15 & 4.0 & 11.0 \\
\hline 229 & 1970 & 3 & 23 & 16 & 54 & 51.0 & 53.80 & 133.50 & 15 & 4.4 & 11.0 \\
\hline 233 & 1970 & 7 & 19 & 17 & 19 & 38.0 & 56.00 & 128.80 & 15 & 3.3 & 10.0 \\
\hline 240 & 1970 & 8 & 29 & 14 & 59 & 21.0 & 51.10 & 135.10 & $30-40$ & 5.5 & 13.9 \\
\hline 241 & 1970 & 8 & 29 & 15 & 31 & 15.0 & 51.00 & 135.30 & 20 & 4.4 & 11.2 \\
\hline 242 & 1970 & 9 & 3 & 7 & 38 & 26.0 & 54.10 & 128.70 & 15 & 3.3 & 10.0 \\
\hline 243 & 1970 & 9 & 17 & 1 & 25 & 40.0 & 56.10 & 137.80 & 15 & 3.9 & 11.0 \\
\hline 245 & 1970 & 10 & 12 & 9 & 33 & 35.7 & 42.79 & 131.01 & 542 & 5.1 & \\
\hline 255 & 1971 & 1 & 21 & 7 & 44 & 22.0 & 55.00 & 124.20 & 15 & 3.3 & 10.0 \\
\hline 256 & 1971 & 1 & 21 & 15 & 27 & 51.0 & 55.40 & 122.30 & 15 & 3.3 & 10.0 \\
\hline 257 & 1971 & 1 & 24 & 20 & 36 & 51.5 & 54.36 & 123.11 & 15 & 3.3 & 10.0 \\
\hline 264 & 1971 & 3 & 12 & 15 & 22 & 39.0 & 53.10 & 139.30 & 15 & 3.6 & 10.8 \\
\hline 266 & 1971 & 3 & 18 & 20 & 8 & 41.0 & 55.70 & 133.70 & 15 & 4.0 & 11.0 \\
\hline 268 & 1971 & 3 & 24 & 2 & 0 & 12.0 & 56.20 & 134.90 & 15 & 3.3 & 10.0 \\
\hline 279 & 1971 & 5 & 28 & 9 & 25 & 31.0 & 54.30 & 125.80 & 15 & 3.3 & 10.0 \\
\hline 280 & 1971 & 6 & 14 & 14 & 25 & 55.0 & 56.10 & 123.60 & 10 & 4.3 & 12.0 \\
\hline 284 & 1971 & 7 & 30 & 5 & 12 & 41.0 & 56.20 & 133.50 & 15 & 4.0 & 11.0 \\
\hline 291 & 1971 & 9 & 23 & 0 & 51 & 36.9 & 45.82 & 137.22 & 373 & 4.8 & \\
\hline 299 & 1971 & 12 & 18 & 10 & 48 & 52.0 & 43.10 & 133.20 & $5-7$ & 4.1 & 11.4 \\
\hline 300 & 1971 & 12 & 27 & 11 & 23 & 18.0 & 55.50 & 135.40 & 15 & 3.3 & 10.0 \\
\hline 310 & 1972 & 1 & 20 & 15 & 38 & 41.0 & 54.30 & 127.30 & 15 & 3.3 & 10.0 \\
\hline 312 & 1972 & 1 & 30 & 22 & 3 & 32.0 & 55.40 & 124.10 & 15 & 3.3 & 10.0 \\
\hline 323 & 1972 & 2 & 28 & 17 & 32 & 29.0 & 43.39 & 132.30 & 469 & 4.4 & \\
\hline 327 & 1972 & 4 & 4 & 11 & 32 & 23.0 & 54.60 & 135.00 & 15 & 3.9 & 11.0 \\
\hline 335 & 1972 & 5 & 9 & 8 & 28 & 5.0 & 42.50 & 137.90 & 300 & 4.2 & \\
\hline 336 & 1972 & 5 & 13 & 16 & 17 & 53.0 & 55.50 & 124.00 & 15 & 3.3 & 10.0 \\
\hline 338 & 1972 & 5 & 19 & 8 & 42 & 50.0 & 54.10 & 128.50 & 15 & 3.3 & 10.0 \\
\hline 341 & 1972 & 6 & 13 & 10 & 45 & 5.0 & 54.30 & 126.50 & 18 & 5.6 & 14.0 \\
\hline 343 & 1972 & 6 & 20 & 10 & 33 & 25.6 & 41.81 & 135.51 & 357 & 4.8 & \\
\hline 345 & 1972 & 7 & 3 & 1 & 32 & 37.0 & 53.80 & 123.50 & 15 & 3.3 & 10.0 \\
\hline 349 & 1972 & 8 & 11 & 12 & 45 & 23.0 & 53.90 & 128.20 & 15 & 3.3 & 10.0 \\
\hline 351 & 1972 & 9 & 8 & 19 & 48 & 57.0 & 56.10 & 130.60 & 10 & 4.4 & 12.0 \\
\hline 352 & 1972 & 9 & 19 & 5 & 31 & 7.0 & 53.90 & 135.40 & 15 & 3.3 & 10.0 \\
\hline 356 & 1972 & 11 & 10 & 22 & 6 & 42.0 & 54.40 & 125.90 & 15 & 3.3 & 10.0 \\
\hline 368 & 1973 & 2 & 22 & 5 & 44 & 16.0 & 54.10 & 123.90 & 15 & 3.3 & 10.0 \\
\hline 371 & 1973 & 3 & 1 & 14 & 30 & 3.0 & 56.20 & 128.50 & 10 & 3.3 & 10.0 \\
\hline 380 & 1973 & 4 & 29 & 6 & 18 & 51.0 & 54.60 & 124.70 & 15 & 3.3 & 10.0 \\
\hline 384 & 1973 & 5 & 6 & 14 & 39 & 27.3 & 43.54 & 132.36 & 486 & 5.2 & \\
\hline 387 & 1973 & 6 & 17 & 1 & 2 & 40.0 & 54.30 & 140.50 & $20-10$ & 3.4 & 10.2 \\
\hline 398 & 1973 & 9 & 10 & 7 & 43 & 33.1 & 42.41 & 131.11 & 573 & 6.5 & \\
\hline
\end{tabular}


Приложение 1А. Каталог землетрясений региона Приамурье и Приморье 1865-2015 гг. магнитудой М $\geq 3.3$.

\begin{tabular}{|c|c|c|c|c|c|c|c|c|c|c|c|}
\hline \multirow{2}{*}{$\frac{\text { № }}{\text { ח/ח }}$} & \multicolumn{3}{|c|}{ Дата } & \multicolumn{3}{|c|}{$t_{0}$} & \multicolumn{2}{|c|}{ Эпицентр } & \multirow{2}{*}{$\begin{array}{c}h \\
\text { КМ }\end{array}$} & \multirow[b]{2}{*}{$M / M L H$} & \multirow[b]{2}{*}{$K \mathrm{p}$} \\
\hline & $\Gamma$ & $\mathrm{M}$ & д & ч & мин & $\mathrm{c}$ & $\varphi^{\circ}, \mathrm{N}$ & $\lambda^{\circ}, \mathrm{E}$ & & & \\
\hline 399 & 1973 & 9 & 29 & 0 & 44 & 2.0 & 42.00 & 131.00 & 600 & 7.2 & \\
\hline 400 & 1973 & 10 & 26 & 11 & 26 & 56.4 & 56.20 & 123.57 & 10 & 3.3 & 10.0 \\
\hline 402 & 1973 & 11 & 2 & 7 & 31 & 35.0 & 54.40 & 125.40 & $5-10$ & 5.5 & 14.0 \\
\hline 404 & 1973 & 11 & 2 & 12 & 14 & 48.0 & 54.30 & 125.80 & 10 & 3.3 & 10.0 \\
\hline 409 & 1973 & 11 & 4 & 13 & 1 & 42.0 & 53.90 & 141.30 & $20-30$ & 4.7 & 12.5 \\
\hline 412 & 1973 & 11 & 15 & 11 & 11 & 16.0 & 54.10 & 126.00 & 10 & 3.3 & 10.0 \\
\hline 420 & 1974 & 1 & 10 & 10 & 31 & 48.4 & 42.43 & 130.90 & 536 & 4.5 & \\
\hline 437 & 1974 & 4 & 28 & 0 & 59 & 9.0 & 50.40 & 139.20 & 10 & 3.4 & 10.2 \\
\hline 439 & 1974 & 5 & 16 & 9 & 5 & 20.3 & 56.18 & 123.67 & 10 & 3.3 & 10.0 \\
\hline 447 & 1974 & 5 & 30 & 5 & 58 & 27.0 & 54.20 & 127.60 & 10 & 3.3 & 10.0 \\
\hline 448 & 1974 & 6 & 5 & 16 & 40 & 25.0 & 54.00 & 129.00 & 10 & 3.3 & 10.0 \\
\hline 451 & 1974 & 6 & 8 & 20 & 51 & 23.0 & 55.40 & 134.90 & 10 & 3.3 & 10.0 \\
\hline 457 & 1974 & 7 & 27 & 12 & 19 & 50.0 & 54.30 & 127.40 & 10 & 3.3 & 10.0 \\
\hline 464 & 1974 & 8 & 19 & 13 & 24 & 21.0 & 54.20 & 127.50 & 10 & 3.3 & 10.0 \\
\hline 465 & 1974 & 8 & 25 & 22 & 49 & 59.0 & 55.60 & 123.00 & 10 & 3.3 & 10.0 \\
\hline 472 & 1974 & 9 & 30 & 20 & 1 & 46.0 & 53.40 & 127.10 & 10 & 3.3 & 10.0 \\
\hline 481 & 1974 & 10 & 18 & 6 & 34 & 48.0 & 56.40 & 127.30 & 10 & 3.3 & 10.0 \\
\hline 485 & 1974 & 11 & 21 & 2 & 35 & 6.0 & 54.20 & 124.00 & 10 & 4.4 & 13.0 \\
\hline 556 & 1975 & 3 & 27 & 6 & 58 & 48.0 & 52.60 & 131.40 & 30 & 3.3 & 10.0 \\
\hline 567 & 1975 & 4 & 23 & 0 & 17 & 57.3 & 43.87 & 131.99 & 496 & 4.7 & \\
\hline 589 & 1975 & 6 & 29 & 12 & 24 & 42.0 & 53.20 & 132.20 & $20-30$ & 5.3 & 13.5 \\
\hline 596 & 1975 & 7 & 31 & 16 & 19 & 0.0 & 56.50 & 135.40 & 30 & 3.9 & 11.0 \\
\hline 599 & 1975 & 9 & 21 & 9 & 30 & 40.0 & 54.30 & 122.20 & 20 & 4.0 & 11.0 \\
\hline 600 & 1975 & 9 & 21 & 10 & 3 & 31.0 & 54.20 & 122.30 & 10 & 3.3 & 10.0 \\
\hline 605 & 1975 & 10 & 5 & 14 & 34 & 34.9 & 42.54 & 137.60 & 250 & 4.3 & \\
\hline 606 & 1975 & 10 & 7 & 20 & 0 & 19.0 & 49.80 & 132.60 & 30 & 4.2 & 11.5 \\
\hline 607 & 1975 & 10 & 13 & 20 & 56 & 17.0 & 54.50 & 122.20 & 30 & 3.3 & 10.0 \\
\hline 628 & 1975 & 12 & 30 & 4 & 11 & 23.2 & 41.95 & 133.61 & 450 & 4.6 & \\
\hline 637 & 1976 & 1 & 29 & 11 & 21 & 14.0 & 55.50 & 128.80 & 15 & 3.3 & 10.0 \\
\hline 645 & 1976 & 2 & 21 & 4 & 13 & 4.0 & 43.15 & 137.30 & 283 & 4.8 & \\
\hline 649 & 1976 & 3 & 26 & 9 & 19 & 11.0 & 54.20 & 122.00 & 16 & 3.3 & 10.0 \\
\hline 652 & 1976 & 4 & 11 & 13 & 1 & 48.5 & 42.79 & 131.08 & 539 & 4.6 & \\
\hline 653 & 1976 & 4 & 11 & 13 & 3 & 36.8 & 42.81 & 131.06 & 542 & 4.9 & \\
\hline 665 & 1976 & 6 & 14 & 11 & 57 & 58.0 & 55.50 & 131.50 & 10 & 3.6 & 10.5 \\
\hline 667 & 1976 & 6 & 17 & 5 & 42 & 0.0 & 55.10 & 136.30 & 15 & 4.0 & 11.0 \\
\hline 670 & 1976 & 6 & 27 & 16 & 3 & 29.0 & 55.50 & 131.10 & 10 & 4.0 & 11.0 \\
\hline 681 & 1976 & 7 & 30 & 21 & 53 & 22.0 & 55.60 & 133.10 & 10 & 4.1 & 12.0 \\
\hline 682 & 1976 & 7 & 30 & 22 & 13 & 53.0 & 55.00 & 133.60 & 15 & 3.3 & 10.0 \\
\hline 684 & 1976 & 8 & 4 & 3 & 52 & 49.0 & 56.40 & 132.00 & 10 & 3.3 & 10.0 \\
\hline 685 & 1976 & 8 & 6 & 8 & 56 & 45.0 & 55.30 & 134.30 & 15 & 3.5 & 10.5 \\
\hline 687 & 1976 & 8 & 9 & 7 & 18 & 18.0 & 56.30 & 132.80 & 10 & 3.3 & 10.0 \\
\hline 692 & 1976 & 9 & 11 & 6 & 55 & 2.0 & 53.10 & 136.60 & $10-20$ & 4.5 & 11.5 \\
\hline 695 & 1976 & 9 & 12 & 10 & 56 & 12.0 & 52.70 & 137.10 & 20 & 4.0 & 11.0 \\
\hline
\end{tabular}


Приложение 1А. Каталог землетрясений региона Приамурье и Приморье 1865-2015 гг. магнитудой М $\geq 3.3$.

\begin{tabular}{|c|c|c|c|c|c|c|c|c|c|c|c|}
\hline № & & Іата & & & $t_{0}$ & & Эпи & нтр & $h$ & & \\
\hline$\Pi / \Pi$ & $\Gamma$ & $\mathrm{M}$ & д & ч & мин & $\mathrm{c}$ & $\varphi^{\circ}, \mathrm{N}$ & $\lambda^{\circ}, \mathrm{E}$ & км & $M / M L H$ & $K \mathrm{p}$ \\
\hline 696 & 1976 & 9 & 13 & 20 & 32 & 11.0 & 51.90 & 137.00 & $10-20$ & 4.2 & 11.0 \\
\hline 697 & 1976 & 9 & 13 & 22 & 0 & 21.0 & 51.70 & 138.30 & $10-20$ & 3.3 & 10.0 \\
\hline 700 & 1976 & 9 & 29 & 9 & 5 & 30.0 & 56.60 & 134.10 & $10-20$ & 3.6 & 10.5 \\
\hline 707 & 1976 & 11 & 20 & 1 & 55 & 5.0 & 54.20 & 122.00 & 10 & 3.3 & 10.0 \\
\hline 708 & 1976 & 11 & 20 & 8 & 2 & 58.0 & 54.10 & 122.00 & 10 & 4.0 & 10.0 \\
\hline 709 & 1976 & 11 & 21 & 15 & 51 & 55.9 & 54.14 & 122.00 & 10 & 3.3 & 10.0 \\
\hline 715 & 1976 & 11 & 24 & 18 & 33 & 36.3 & 54.14 & 122.04 & 27 & 5.0 & 13.0 \\
\hline 717 & 1976 & 11 & 24 & 19 & 17 & 45.8 & 54.15 & 122.00 & 15 & 3.3 & 10.0 \\
\hline 726 & 1976 & 12 & 3 & 1 & 50 & 33.7 & 54.15 & 122.09 & 12 & 4.4 & 12.0 \\
\hline 727 & 1976 & 12 & 3 & 3 & 55 & 57.3 & 54.17 & 122.00 & 13 & 4.0 & 11.0 \\
\hline 732 & 1976 & 12 & 9 & 13 & 15 & 29.0 & 52.50 & 136.50 & $10-20$ & 3.3 & 10.0 \\
\hline 733 & 1976 & 12 & 9 & 13 & 39 & 31.0 & 52.60 & 136.80 & $10-20$ & 3.3 & 10.0 \\
\hline 735 & 1976 & 12 & 13 & 11 & 27 & 6.4 & 56.02 & 125.19 & 10 & 3.3 & 10.0 \\
\hline 740 & 1977 & 1 & 15 & 17 & 38 & 2.0 & 55.42 & 124.05 & $5-10$ & 3.3 & 10.0 \\
\hline 741 & 1977 & 1 & 16 & 0 & 9 & 36.0 & 55.15 & 130.35 & $5-15$ & 4.0 & 11.0 \\
\hline 747 & 1977 & 2 & 3 & 21 & 31 & 50.2 & 42.90 & 131.07 & 520 & 4.8 & \\
\hline 756 & 1977 & 3 & 9 & 14 & 27 & 54.0 & 41.30 & 130.90 & 550 & 6.1 & \\
\hline 771 & 1977 & 4 & 22 & 18 & 29 & 10.0 & 54.20 & 125.00 & 5 & 3.7 & 10.5 \\
\hline 781 & 1977 & 5 & 26 & 9 & 52 & 13.5 & 55.61 & 121.79 & 10 & 3.3 & 10.0 \\
\hline 782 & 1977 & 5 & 27 & 15 & 55 & 30.0 & 51.20 & 138.50 & 15 & 3.3 & 10.0 \\
\hline 790 & 1977 & 6 & 11 & 19 & 28 & 37.0 & 52.80 & 123.60 & $10-30$ & 3.9 & 11.0 \\
\hline 798 & 1977 & 6 & 24 & 4 & 47 & 46.0 & 56.70 & 132.20 & 15 & 3.9 & 11.0 \\
\hline 807 & 1977 & 7 & 20 & 0 & 31 & 40.0 & 54.60 & 126.20 & 15 & 4.3 & 12.0 \\
\hline 809 & 1977 & 7 & 20 & 2 & 3 & 39.0 & 54.60 & 126.30 & 15 & 3.6 & 10.5 \\
\hline 812 & 1977 & 7 & 30 & 0 & 19 & 47.0 & 55.00 & 125.60 & 15 & 3.3 & 10.0 \\
\hline 815 & 1977 & 8 & 8 & 20 & 49 & 17.0 & 51.40 & 138.40 & 33 & 3.3 & 10.0 \\
\hline 818 & 1977 & 8 & 15 & 19 & 2 & 24.0 & 50.00 & 132.90 & 15 & 3.3 & 10.0 \\
\hline 820 & 1977 & 8 & 16 & 13 & 56 & 58.0 & 54.00 & 128.90 & $5-20$ & 5.0 & 13.0 \\
\hline 821 & 1977 & 8 & 16 & 15 & 14 & 58.0 & 53.80 & 128.80 & $20-30$ & 4.5 & 12.0 \\
\hline 824 & 1977 & 8 & 16 & 22 & 9 & 47.0 & 53.85 & 128.80 & $20-30$ & 3.3 & 10.0 \\
\hline 827 & 1977 & 8 & 17 & 23 & 26 & 18.0 & 55.10 & 134.80 & $10-15$ & 3.3 & 10.0 \\
\hline 828 & 1977 & 8 & 20 & 7 & 28 & 49.9 & 41.90 & 133.40 & 444 & 4.5 & \\
\hline 833 & 1977 & 9 & 9 & 2 & 35 & 2.0 & 42.88 & 131.43 & 530 & 4.7 & \\
\hline 838 & 1977 & 10 & 12 & 0 & 46 & 23.7 & 41.73 & 133.73 & 448 & 4.5 & \\
\hline 843 & 1977 & 10 & 23 & 11 & 19 & 27.0 & 43.35 & 135.80 & 359 & 4.3 & \\
\hline 847 & 1977 & 11 & 1 & 3 & 54 & 30.0 & 55.90 & 130.60 & $20-30$ & 4.8 & 12.5 \\
\hline 851 & 1977 & 11 & 17 & 19 & 55 & 43.0 & 50.70 & 132.10 & 50 & 4.6 & 12.0 \\
\hline 856 & 1977 & 12 & 2 & 23 & 2 & 27.0 & 51.35 & 133.70 & 20-30 & 3.7 & 10.5 \\
\hline 857 & 1977 & 12 & 3 & 17 & 6 & 21.8 & 41.60 & 131.10 & 538 & 4.5 & \\
\hline 859 & 1977 & 12 & 10 & 11 & 42 & 24.0 & 54.00 & 126.10 & 10 & 3.3 & 10.0 \\
\hline 860 & 1977 & 12 & 13 & 16 & 32 & 19.0 & 51.85 & 132.60 & $10-20$ & 3.3 & 10.0 \\
\hline 865 & 1978 & 1 & 2 & 23 & 1 & 36.0 & 51.00 & 134.60 & 15 & 3.7 & 10.5 \\
\hline 867 & 1978 & 1 & 11 & 22 & 13 & 42.0 & 53.01 & 128.91 & 20 & 3.7 & 10.5 \\
\hline
\end{tabular}


Приложение 1А. Каталог землетрясений региона Приамурье и Приморье 1865-2015 гг. магнитудой М $\geq 3.3$.

\begin{tabular}{|c|c|c|c|c|c|c|c|c|c|c|c|}
\hline \multirow{2}{*}{$\begin{array}{c}\text { № } \\
\Pi / \Pi\end{array}$} & \multicolumn{3}{|c|}{ Дата } & \multicolumn{3}{|c|}{$t_{0}$} & \multicolumn{2}{|c|}{ Эпицентр } & \multirow{2}{*}{$\frac{h}{\text { км }}$} & \multirow[b]{2}{*}{$M / M L H$} & \multirow[b]{2}{*}{$K \mathrm{p}$} \\
\hline & $\Gamma$ & $\mathrm{M}$ & д & ч & мин & $\mathrm{c}$ & $\varphi^{\circ}, \mathrm{N}$ & $\lambda^{\circ}, \mathrm{E}$ & & & \\
\hline 868 & 1978 & 1 & 12 & 4 & 24 & 19.0 & 54.20 & 131.90 & 15 & 4.2 & 12.2 \\
\hline 873 & 1978 & 2 & 1 & 1 & 8 & 46.0 & 54.60 & 123.10 & 10 & 4.5 & 12.0 \\
\hline 877 & 1978 & 2 & 13 & 5 & 27 & 3.0 & 54.60 & 122.60 & 10 & 3.7 & 10.5 \\
\hline 885 & 1978 & 3 & 11 & 2 & 19 & 13.0 & 54.90 & 136.10 & 10 & 3.3 & 10.0 \\
\hline 891 & 1978 & 3 & 24 & 17 & 36 & 27.0 & 53.80 & 135.60 & 15 & 4.0 & 11.0 \\
\hline 912 & 1978 & 4 & 28 & 14 & 56 & 24.0 & 53.66 & 125.20 & 5 & 3.6 & 10.5 \\
\hline 935 & 1978 & 6 & 15 & 3 & 19 & 9.0 & 43.41 & 136.45 & 365 & 5.0 & \\
\hline 939 & 1978 & 6 & 26 & 2 & 51 & 22.0 & 55.75 & 125.85 & 10 & 3.3 & 10.0 \\
\hline 942 & 1978 & 6 & 30 & 11 & 57 & 1.0 & 53.87 & 125.90 & 20 & 4.1 & 12.0 \\
\hline 945 & 1978 & 7 & 3 & 2 & 56 & 32.0 & 47.20 & 132.00 & 10 & 4.0 & 11.0 \\
\hline 946 & 1978 & 7 & 3 & 21 & 1 & 47.0 & 43.21 & 130.90 & 524 & 4.6 & \\
\hline 947 & 1978 & 7 & 4 & 20 & 30 & 44.0 & 53.50 & 132.60 & 10 & 4.2 & 11.5 \\
\hline 955 & 1978 & 8 & 5 & 16 & 44 & 8.0 & 53.66 & 131.70 & 5 & 3.3 & 10.0 \\
\hline 957 & 1978 & 8 & 10 & 7 & 56 & 14.0 & 49.70 & 132.50 & 10 & 4.0 & 11.0 \\
\hline 963 & 1978 & 8 & 20 & 7 & 28 & 49.9 & 41.90 & 133.40 & 444 & 4.5 & \\
\hline 964 & 1978 & 8 & 21 & 10 & 15 & 54.0 & 55.22 & 124.80 & 10 & 4.0 & 11.2 \\
\hline 965 & 1978 & 8 & 21 & 10 & 17 & 40.0 & 55.10 & 124.80 & 10 & 3.3 & 10.0 \\
\hline 967 & 1978 & 9 & 2 & 21 & 14 & 2.0 & 54.90 & 135.80 & 10 & 3.3 & 10.0 \\
\hline 971 & 1978 & 9 & 10 & 12 & 45 & 41.3 & 42.44 & 137.08 & 298 & 4.7 & \\
\hline 996 & 1978 & 12 & 1 & 13 & 26 & 1.0 & 55.30 & 124.00 & 10 & 3.3 & 10.0 \\
\hline 999 & 1978 & 12 & 11 & 14 & 6 & 2.0 & 53.70 & 125.92 & 10 & 3.3 & 10.0 \\
\hline 1007 & 1978 & 12 & 28 & 13 & 19 & 54.0 & 55.92 & 127.42 & 5 & 3.7 & 10.5 \\
\hline 1008 & 1979 & 1 & 3 & 3 & 20 & 27.0 & 52.50 & 127.60 & 20 & 3.3 & 10.0 \\
\hline 1013 & 1979 & 1 & 4 & 21 & 50 & 18.0 & 54.10 & 122.70 & 33 & 3.6 & 10.5 \\
\hline 1027 & 1979 & 1 & 31 & 12 & 36 & 24.2 & 42.79 & 131.21 & 536 & 5.2 & \\
\hline 1073 & 1979 & 4 & 27 & 19 & 38 & 16.0 & 55.90 & 130.50 & 30 & 4.3 & 13.1 \\
\hline 1091 & 1979 & 5 & 17 & 6 & 39 & 8.0 & 53.69 & 126.10 & 5 & 3.9 & 11.0 \\
\hline 1094 & 1979 & 5 & 23 & 17 & 37 & 32.0 & 53.56 & 126.03 & $0-5$ & 3.4 & 10.0 \\
\hline 1098 & 1979 & 5 & 31 & 10 & 49 & 24.0 & 55.59 & 130.74 & $0-5$ & 3.9 & 11.0 \\
\hline 1101 & 1979 & 6 & 13 & 10 & 52 & 6.0 & 43.20 & 132.40 & 107 & 4.9 & \\
\hline 1111 & 1979 & 6 & 27 & 17 & 45 & 12.0 & 53.10 & 135.10 & 5 & 3.3 & 10.0 \\
\hline 1115 & 1979 & 7 & 3 & 8 & 43 & 0.0 & 50.60 & 132.40 & 5 & 3.3 & 10.0 \\
\hline 1128 & 1979 & 7 & 22 & 13 & 11 & 21.0 & 50.50 & 136.20 & 10 & 3.3 & 10.0 \\
\hline 1132 & 1979 & 8 & 4 & 18 & 48 & 20.0 & 55.50 & 130.20 & 15 & 3.3 & 10.0 \\
\hline 1137 & 1979 & 8 & 16 & 21 & 31 & 24.8 & 41.85 & 130.86 & 566 & 5.4 & \\
\hline 1138 & 1979 & 8 & 24 & 15 & 15 & 30.0 & 54.10 & 127.50 & 15 & 3.6 & 10.5 \\
\hline 1146 & 1979 & 9 & 2 & 0 & 39 & 31.0 & 50.70 & 134.30 & 15 & 3.3 & 10.0 \\
\hline 1162 & 1979 & 9 & 19 & 12 & 18 & 13.0 & 54.03 & 127.75 & 20 & 3.3 & 10.0 \\
\hline 1167 & 1979 & 9 & 30 & 14 & 14 & 19.0 & 42.97 & 131.37 & 558 & 4.2 & \\
\hline 1171 & 1979 & 10 & 6 & 1 & 14 & 2.0 & 51.90 & 133.30 & 20 & 4.3 & 12.9 \\
\hline 1174 & 1979 & 10 & 11 & 16 & 15 & 30.0 & 52.70 & 126.00 & 25 & 3.9 & 11.0 \\
\hline 1178 & 1979 & 11 & 5 & 3 & 37 & 3.0 & 55.42 & 123.00 & 5 & 3.3 & 10.0 \\
\hline 1183 & 1979 & 11 & 19 & 11 & 30 & 58.0 & 46.80 & 129.80 & 33 & 4.2 & 11.7 \\
\hline
\end{tabular}


Приложение 1А. Каталог землетрясений региона Приамурье и Приморье 1865-2015 гг. магнитудой М $\geq 3.3$.

\begin{tabular}{|c|c|c|c|c|c|c|c|c|c|c|c|}
\hline № & & Іата & & & $t_{0}$ & & ЭПи & нтр & $h$ & & \\
\hline$\Pi / \Pi$ & $\Gamma$ & $\mathrm{M}$ & д & ч & мин & $\mathrm{c}$ & $\varphi^{\circ}, \mathrm{N}$ & $\lambda^{\circ}, \mathrm{E}$ & км & $M / M L H$ & $K \mathrm{p}$ \\
\hline 1185 & 1979 & 11 & 26 & 19 & 36 & 56.0 & 48.20 & 132.30 & 33 & 3.6 & 10.5 \\
\hline 1197 & 1979 & 12 & 25 & 3 & 36 & 53.0 & 43.20 & 131.20 & 535 & 4.9 & \\
\hline 1201 & 1979 & 12 & 30 & 20 & 46 & 34.0 & 54.80 & 125.30 & 10 & 3.3 & 10.0 \\
\hline 1228 & 1980 & 2 & 5 & 13 & 14 & 5.0 & 55.95 & 122.70 & 5 & 3.3 & 10.0 \\
\hline 1235 & 1980 & 2 & 14 & 4 & 9 & 48.0 & 52.26 & 126.83 & 30 & 3.3 & 10.0 \\
\hline 1244 & 1980 & 2 & 25 & 23 & 50 & 4.0 & 54.85 & 125.26 & 20 & 4.2 & 12.0 \\
\hline 1264 & 1980 & 3 & 21 & 15 & 3 & 57.5 & 51.50 & 133.20 & 10 & 3.6 & 10.5 \\
\hline 1266 & 1980 & 3 & 21 & 17 & 26 & 52.5 & 51.40 & 133.20 & 10 & 3.9 & 11.0 \\
\hline 1273 & 1980 & 4 & 6 & 2 & 28 & 56.5 & 53.95 & 127.90 & $0-10$ & 4.4 & 12.0 \\
\hline 1274 & 1980 & 4 & 6 & 2 & 53 & 28.8 & 41.65 & 137.10 & 300 & 4.8 & \\
\hline 1294 & 1980 & 5 & 14 & 8 & 24 & 10.0 & 49.70 & 130.10 & 10 & 4.1 & 11.5 \\
\hline 1295 & 1980 & 5 & 14 & 19 & 20 & 32.5 & 49.68 & 130.08 & $0-5$ & 3.7 & 10.5 \\
\hline 1325 & 1980 & 8 & 29 & 16 & 31 & 58.0 & 56.00 & 129.40 & 30 & 3.6 & 10.5 \\
\hline 1343 & 1980 & 10 & 2 & 22 & 0 & 10.9 & 43.30 & 135.35 & 359 & 4.3 & \\
\hline 1346 & 1980 & 10 & 15 & 2 & 52 & 54.7 & 54.66 & 133.80 & 10 & 3.9 & 11.0 \\
\hline 1366 & 1980 & 12 & 7 & 2 & 34 & 42.0 & 45.00 & 135.20 & 30 & 4.7 & 13.0 \\
\hline 1373 & 1980 & 12 & 23 & 1 & 38 & 4.0 & 53.37 & 132.15 & 10 & 3.6 & 10.5 \\
\hline 1390 & 1981 & 2 & 12 & 18 & 51 & 0.9 & 42.74 & 137.50 & 291 & 4.7 & \\
\hline 1430 & 1981 & 5 & 16 & 8 & 45 & 42.1 & 48.69 & 122.10 & $0-17$ & 3.3 & 10.0 \\
\hline 1434 & 1981 & 5 & 27 & 2 & 57 & 0.8 & 54.29 & 125.50 & $5-10$ & 3.4 & 10.1 \\
\hline 1435 & 1981 & 5 & 27 & 8 & 45 & 21.5 & 54.25 & 125.55 & $5-10$ & 3.4 & 10.1 \\
\hline 1436 & 1981 & 5 & 28 & 12 & 17 & 9.0 & 48.45 & 130.65 & 10 & 3.8 & 10.9 \\
\hline 1437 & 1981 & 5 & 31 & 23 & 59 & 34.3 & 44.49 & 137.33 & 288 & 5.2 & \\
\hline 1464 & 1981 & 9 & 5 & 1 & 53 & 0.5 & 51.21 & 132.30 & 30 & 3.6 & 10.4 \\
\hline 1472 & 1981 & 9 & 19 & 7 & 27 & 1.0 & 43.18 & 130.98 & 567 & 4.5 & \\
\hline 1474 & 1981 & 10 & 5 & 4 & 28 & 13.1 & 42.82 & 131.31 & 531 & 4.7 & \\
\hline 1480 & 1981 & 10 & 22 & 12 & 45 & 40.5 & 53.20 & 134.50 & $10-30$ & 3.6 & 10.4 \\
\hline 1483 & 1981 & 11 & 8 & 1 & 36 & 23.8 & 48.81 & 131.70 & 5 & 3.3 & 9.9 \\
\hline 1489 & 1981 & 11 & 22 & 21 & 44 & 50.2 & 51.95 & 122.59 & 20 & 3.7 & 10.6 \\
\hline 1491 & 1981 & 11 & 27 & 17 & 21 & 44.3 & 42.93 & 131.19 & 525 & 5.3 & \\
\hline 1520 & 1982 & 1 & 14 & 16 & 25 & 25.3 & 53.80 & 137.22 & 10 & 3.7 & 10.6 \\
\hline 1523 & 1982 & 1 & 19 & 4 & 42 & 53.1 & 50.24 & 136.98 & 10 & 3.3 & 10.0 \\
\hline 1535 & 1982 & 2 & 12 & 1 & 24 & 54.6 & 48.39 & 130.93 & 10 & 3.3 & 10.0 \\
\hline 1537 & 1982 & 2 & 12 & 23 & 33 & 57.2 & 55.74 & 130.44 & 10 & 3.3 & 9.9 \\
\hline 1556 & 1982 & 3 & 10 & 20 & 33 & 55.4 & 51.82 & 131.92 & 15 & 4.1 & 11.4 \\
\hline 1568 & 1982 & 3 & 25 & 10 & 52 & 32.9 & 51.44 & 131.96 & 10 & 3.3 & 9.8 \\
\hline 1576 & 1982 & 4 & 6 & 7 & 22 & 2.2 & 55.53 & 130.46 & 10 & 3.4 & 10.1 \\
\hline 1580 & 1982 & 4 & 16 & 8 & 11 & 11.1 & 51.11 & 132.52 & $10-30$ & 3.3 & 9.7 \\
\hline 1582 & 1982 & 4 & 18 & 2 & 50 & 9.6 & 55.56 & 130.37 & 10 & 3.8 & 10.9 \\
\hline 1594 & 1982 & 4 & 27 & 19 & 40 & 53.8 & 51.40 & 136.70 & $10-30$ & 4.0 & 11.2 \\
\hline 1598 & 1982 & 5 & 2 & 3 & 28 & 37.9 & 52.59 & 136.22 & $10-30$ & 3.6 & 10.4 \\
\hline 1599 & 1982 & 5 & 4 & 10 & 59 & 41.5 & 48.55 & 126.05 & 15 & 3.4 & 10.1 \\
\hline 1606 & 1982 & 5 & 30 & 11 & 18 & 55.8 & 53.45 & 132.56 & 15 & 3.3 & 9.5 \\
\hline
\end{tabular}


Приложение 1А. Каталог землетрясений региона Приамурье и Приморье 1865-2015 гг. магнитудой М $\geq 3.3$.

\begin{tabular}{|c|c|c|c|c|c|c|c|c|c|c|c|}
\hline \multirow{2}{*}{$\begin{array}{c}\text { № } \\
\Pi / \Pi\end{array}$} & \multicolumn{3}{|c|}{ Дата } & \multicolumn{3}{|c|}{$t_{0}$} & \multicolumn{2}{|c|}{ Эпицентр } & \multirow{2}{*}{$\begin{array}{c}h \\
\text { км }\end{array}$} & \multirow[b]{2}{*}{$M / M L H$} & \multirow[b]{2}{*}{$K \mathrm{p}$} \\
\hline & $\Gamma$ & $\mathrm{M}$ & д & ч & мин & $\mathrm{c}$ & $\varphi^{\circ}, \mathrm{N}$ & $\lambda^{\circ}, \mathrm{E}$ & & & \\
\hline 1617 & 1982 & 7 & 7 & 1 & 40 & 16.7 & 55.73 & 125.52 & 10 & 3.6 & 10.4 \\
\hline 1671 & 1982 & 10 & 5 & 1 & 52 & 27.5 & 54.26 & 126.02 & 10 & 3.4 & 10.2 \\
\hline 1674 & 1982 & 10 & 11 & 2 & 10 & 27.2 & 54.51 & 126.20 & 10 & 3.3 & 10.0 \\
\hline 1696 & 1982 & 12 & 5 & 13 & 24 & 39.8 & 54.39 & 126.05 & 10 & 3.4 & 10.2 \\
\hline 1708 & 1982 & 12 & 29 & 22 & 36 & 58.7 & 51.64 & 132.90 & 10 & 3.7 & 10.7 \\
\hline 1714 & 1983 & 1 & 22 & 5 & 20 & 26.8 & 53.71 & 135.93 & 5 & 3.6 & 10.4 \\
\hline 1719 & 1983 & 2 & 5 & 9 & 21 & 42.2 & 53.02 & 127.09 & 5 & 4.3 & 11.8 \\
\hline 1721 & 1983 & 2 & 7 & 15 & 34 & 26.9 & 53.54 & 128.62 & 5 & 3.4 & 10.2 \\
\hline 1733 & 1983 & 3 & 10 & 18 & 22 & 38.6 & 47.69 & 130.69 & 5 & 3.7 & 10.6 \\
\hline 1742 & 1983 & 3 & 26 & 19 & 58 & 11.0 & 54.10 & 140.20 & 15 & 3.6 & 10.3 \\
\hline 1752 & 1983 & 4 & 27 & 0 & 30 & 42.1 & 50.68 & 132.13 & $5-30$ & 3.8 & 10.9 \\
\hline 1761 & 1983 & 5 & 27 & 13 & 35 & 47.0 & 46.21 & 136.13 & 438 & 4.5 & \\
\hline 1769 & 1983 & 6 & 8 & 8 & 27 & 0.0 & 51.92 & 132.90 & 5 & 3.6 & 10.5 \\
\hline 1779 & 1983 & 7 & 10 & 14 & 40 & 47.9 & 48.67 & 133.90 & 5 & 3.3 & 10.0 \\
\hline 1789 & 1983 & 7 & 30 & 15 & 42 & 6.5 & 53.42 & 132.63 & $10-15$ & 4.8 & 13.6 \\
\hline 1813 & 1983 & 10 & 8 & 7 & 45 & 26.3 & 44.21 & 130.74 & 551 & 4.3 & \\
\hline 1816 & 1983 & 10 & 24 & 6 & 33 & 26.2 & 43.20 & 134.40 & 422 & 3.5 & \\
\hline 1817 & 1983 & 10 & 29 & 17 & 47 & 4.7 & 43.40 & 135.14 & 383 & 4.6 & \\
\hline 1833 & 1983 & 12 & 3 & 17 & 12 & 58.5 & 47.58 & 130.89 & 15 & 3.4 & 10.1 \\
\hline 1843 & 1984 & 1 & 8 & 23 & 18 & 39.1 & 54.44 & 125.09 & 10 & 3.7 & 10.6 \\
\hline 1844 & 1984 & 1 & 8 & 23 & 19 & 7.6 & 54.38 & 125.01 & 10 & 3.4 & 10.1 \\
\hline 1845 & 1984 & 1 & 10 & 6 & 34 & 45.0 & 54.10 & 140.30 & 5 & 3.5 & 10.0 \\
\hline 1874 & 1984 & 3 & 7 & 12 & 24 & 15.2 & 54.10 & 136.95 & 10 & 3.3 & 10.0 \\
\hline 1878 & 1984 & 3 & 24 & 1 & 3 & 26.7 & 54.53 & 136.96 & $5-10$ & 4.5 & 13.4 \\
\hline 1879 & 1984 & 3 & 24 & 2 & 23 & 43.3 & 54.17 & 136.89 & 10 & 3.6 & 10.4 \\
\hline 1891 & 1984 & 4 & 15 & 7 & 34 & 11.1 & 42.87 & 131.20 & 528 & 4.9 & \\
\hline 1904 & 1984 & 5 & 14 & 22 & 33 & 7.7 & 43.79 & 138.40 & 291 & 4.3 & \\
\hline 1932 & 1984 & 8 & 12 & 14 & 45 & 32.1 & 49.05 & 131.47 & 10 & 3.5 & 10.3 \\
\hline 1940 & 1984 & 9 & 15 & 13 & 52 & 7.3 & 54.25 & 126.26 & 10 & 3.3 & 10.0 \\
\hline 1949 & 1984 & 10 & 20 & 8 & 41 & 37.2 & 54.21 & 126.22 & 5 & 3.6 & 10.5 \\
\hline 1954 & 1984 & 11 & 1 & 21 & 49 & 3.7 & 52.90 & 138.82 & 10 & 3.7 & 10.5 \\
\hline 1962 & 1984 & 11 & 17 & 22 & 40 & 18.1 & 52.72 & 135.59 & 5 & 3.6 & 10.5 \\
\hline 1970 & 1984 & 12 & 6 & 23 & 26 & 44.6 & 46.71 & 130.88 & 10 & 3.3 & 10.2 \\
\hline 1993 & 1985 & 1 & 21 & 23 & 53 & 58.5 & 51.38 & 130.07 & 8 & 3.4 & 10.2 \\
\hline 2000 & 1985 & 1 & 31 & 20 & 2 & 1.0 & 53.50 & 124.69 & 5 & 4.6 & 12.2 \\
\hline 2023 & 1985 & 3 & 11 & 21 & 12 & 7.5 & 53.90 & 128.45 & 10 & 3.8 & 10.7 \\
\hline 2028 & 1985 & 3 & 15 & 15 & 17 & 0.6 & 47.39 & 131.31 & 10 & 3.3 & 9.9 \\
\hline 2038 & 1985 & 3 & 31 & 6 & 13 & 4.7 & 53.34 & 132.79 & 10 & 3.7 & 10.7 \\
\hline 2039 & 1985 & 4 & 2 & 15 & 50 & 18.1 & 50.94 & 132.09 & 10 & 3.4 & 10.1 \\
\hline 2061 & 1985 & 5 & 3 & 0 & 45 & 25.0 & 43.20 & 131.50 & 540 & 3.7 & \\
\hline 2091 & 1985 & 6 & 12 & 4 & 4 & 36.9 & 52.47 & 132.73 & 9 & 3.9 & 10.9 \\
\hline 2098 & 1985 & 6 & 27 & 0 & 37 & 59.5 & 54.03 & 127.85 & 5 & 3.8 & 10.6 \\
\hline 2107 & 1985 & 7 & 7 & 12 & 15 & 51.7 & 55.89 & 126.80 & 25 & 3.4 & 10.2 \\
\hline
\end{tabular}


Приложение 1А. Каталог землетрясений региона Приамурье и Приморье 1865-2015 гг. магнитудой М $\geq 3.3$.

\begin{tabular}{|c|c|c|c|c|c|c|c|c|c|c|c|}
\hline № & & Іата & & & $t_{0}$ & & ЭПи & нтр & $h$ & & \\
\hline$\Pi / \Pi$ & $\Gamma$ & $\mathrm{M}$ & д & ч & мин & $\mathrm{c}$ & $\varphi^{\circ}, \mathrm{N}$ & $\lambda^{\circ}, \mathrm{E}$ & км & $M / M L H$ & $K \mathrm{p}$ \\
\hline 2108 & 1985 & 7 & 8 & 16 & 27 & 39.4 & 54.86 & 126.10 & 25 & 3.9 & 11.0 \\
\hline 2116 & 1985 & 7 & 21 & 22 & 34 & 30.0 & 49.21 & 126.57 & 7 & 4.2 & 11.7 \\
\hline 2133 & 1985 & 9 & 4 & 21 & 3 & 6.2 & 53.73 & 136.02 & 5 & 3.3 & 9.8 \\
\hline 2147 & 1985 & 9 & 22 & 1 & 9 & 30.6 & 54.30 & 123.66 & 25 & 3.4 & 10.1 \\
\hline 2167 & 1985 & 10 & 30 & 3 & 34 & 14.2 & 54.59 & 133.98 & 10 & 3.3 & 9.7 \\
\hline 2172 & 1985 & 11 & 9 & 4 & 9 & 25.2 & 53.83 & 136.86 & 10 & 4.4 & 11.9 \\
\hline 2184 & 1985 & 12 & 4 & 5 & 42 & 7.0 & 55.66 & 125.74 & 10 & 3.9 & 11.0 \\
\hline 2192 & 1985 & 12 & 17 & 16 & 43 & 10.1 & 52.94 & 129.00 & 5 & 3.6 & 10.5 \\
\hline 2205 & 1986 & 1 & 4 & 4 & 56 & 5.0 & 52.70 & 140.30 & 8 & 3.9 & 11.2 \\
\hline 2207 & 1986 & 1 & 6 & 5 & 27 & 25.0 & 53.08 & 134.58 & 10 & 4.4 & 11.9 \\
\hline 2222 & 1986 & 2 & 9 & 12 & 42 & 53.9 & 48.54 & 126.62 & 15 & 5.1 & 12.6 \\
\hline 2224 & 1986 & 2 & 16 & 6 & 21 & 45.5 & 48.43 & 126.10 & 19 & 4.1 & 11.2 \\
\hline 2230 & 1986 & 2 & 28 & 17 & 7 & 22.1 & 48.63 & 126.24 & 13 & 5.7 & 13.8 \\
\hline 2236 & 1986 & 3 & 13 & 11 & 18 & 3.6 & 53.94 & 136.69 & 7 & 3.4 & 10.1 \\
\hline 2250 & 1986 & 4 & 7 & 12 & 19 & 35.5 & 49.58 & 131.58 & 10 & 3.3 & 9.9 \\
\hline 2271 & 1986 & 5 & 12 & 18 & 45 & 50.0 & 43.70 & 134.00 & 445 & 4.3 & \\
\hline 2273 & 1986 & 5 & 15 & 21 & 22 & 46.9 & 51.83 & 131.91 & 5 & 3.4 & 10.2 \\
\hline 2289 & 1986 & 6 & 12 & 5 & 52 & 17.5 & 43.20 & 135.40 & 370 & 3.9 & \\
\hline 2294 & 1986 & 6 & 22 & 15 & 21 & 19.9 & 54.23 & 140.28 & 10 & 3.5 & 10.0 \\
\hline 2296 & 1986 & 6 & 24 & 14 & 14 & 41.8 & 53.38 & 140.39 & 9 & 4.1 & 11.0 \\
\hline 2299 & 1986 & 7 & 1 & 20 & 4 & 16.0 & 54.83 & 131.05 & 9 & 3.3 & 9.8 \\
\hline 2301 & 1986 & 7 & 3 & 22 & 41 & 8.9 & 49.02 & 131.55 & 13 & 4.2 & 11.5 \\
\hline 2302 & 1986 & 7 & 4 & 15 & 1 & 56.5 & 50.23 & 132.38 & 8 & 3.4 & 10.1 \\
\hline 2303 & 1986 & 7 & 9 & 22 & 14 & 57.9 & 54.72 & 126.49 & 8 & 3.7 & 10.7 \\
\hline 2305 & 1986 & 7 & 16 & 14 & 5 & 3.0 & 52.23 & 126.42 & 9 & 3.6 & 10.4 \\
\hline 2313 & 1986 & 7 & 26 & 14 & 46 & 21.7 & 45.32 & 137.07 & 339 & 5.2 & \\
\hline 2315 & 1986 & 7 & 30 & 20 & 41 & 22.1 & 54.04 & 123.52 & 10 & 4.1 & 11.3 \\
\hline 2318 & 1986 & 8 & 3 & 3 & 51 & 3.0 & 42.95 & 136.50 & 372 & 3.7 & \\
\hline 2319 & 1986 & 8 & 7 & 18 & 51 & 26.1 & 55.08 & 123.35 & 16 & 4.8 & 12.7 \\
\hline 2320 & 1986 & 8 & 9 & 2 & 24 & 44.1 & 54.94 & 123.30 & 12 & 3.3 & 9.9 \\
\hline 2322 & 1986 & 8 & 15 & 17 & 53 & 10.2 & 48.69 & 126.60 & 16 & 4.9 & 12.8 \\
\hline 2324 & 1986 & 8 & 15 & 20 & 20 & 36.1 & 49.08 & 126.84 & 14 & 5.6 & 14.0 \\
\hline 2329 & 1986 & 8 & 25 & 20 & 0 & 17.3 & 48.77 & 126.80 & 25 & 3.7 & 10.6 \\
\hline 2330 & 1986 & 8 & 26 & 4 & 45 & 22.6 & 56.00 & 125.95 & 11 & 3.3 & 9.9 \\
\hline 2334 & 1986 & 8 & 30 & 7 & 18 & 46.2 & 52.97 & 140.36 & 10 & 3.5 & 10.0 \\
\hline 2339 & 1986 & 9 & 9 & 22 & 21 & 41.2 & 52.43 & 131.67 & 11 & 4.0 & 11.4 \\
\hline 2346 & 1986 & 9 & 19 & 7 & 47 & 41.0 & 53.71 & 132.15 & 11 & 3.9 & 10.9 \\
\hline 2352 & 1986 & 10 & 7 & 1 & 1 & 17.0 & 55.60 & 126.39 & 13 & 3.3 & 10.0 \\
\hline 2377 & 1986 & 11 & 29 & 20 & 4 & 55.5 & 54.22 & 131.33 & 13 & 3.8 & 10.8 \\
\hline 2416 & 1987 & 2 & 11 & 17 & 42 & 51.2 & 43.12 & 132.35 & 511 & 6.3 & \\
\hline 2428 & 1987 & 3 & 5 & 20 & 39 & 22.2 & 52.51 & 132.53 & 16 & 5.2 & 14.0 \\
\hline 2443 & 1987 & 4 & 3 & 13 & 6 & 12.9 & 52.84 & 134.54 & 11 & 3.6 & 10.3 \\
\hline 2466 & 1987 & 5 & 5 & 16 & 11 & 57.1 & 46.36 & 137.08 & 15 & 3.4 & 10.2 \\
\hline
\end{tabular}


Приложение 1А. Каталог землетрясений региона Приамурье и Приморье 1865-2015 гг. магнитудой М $\geq 3.3$.

\begin{tabular}{|c|c|c|c|c|c|c|c|c|c|c|c|}
\hline № & \multicolumn{3}{|c|}{ Дата } & \multicolumn{3}{|c|}{$t_{0}$} & \multicolumn{2}{|c|}{ Эпицентр } & \multirow{2}{*}{$\begin{array}{c}h \\
\text { км }\end{array}$} & \multirow[b]{2}{*}{$M / M L H$} & \multirow[b]{2}{*}{$K \mathrm{p}$} \\
\hline п/п & $\Gamma$ & $\mathrm{M}$ & д & ч & мин & $\mathrm{c}$ & $\varphi^{\circ}, \mathrm{N}$ & $\lambda^{\circ}, \mathrm{E}$ & & & \\
\hline 2468 & 1987 & 5 & 7 & 3 & 5 & 49.4 & 46.64 & 139.35 & 458 & 7.6 & \\
\hline 2475 & 1987 & 5 & 16 & 9 & 29 & 40.7 & 48.52 & 130.81 & 10 & 3.4 & 10.1 \\
\hline 2485 & 1987 & 6 & 3 & 11 & 36 & 37.0 & 52.55 & 135.96 & 15 & 3.4 & 10.2 \\
\hline 2486 & 1987 & 6 & 3 & 17 & 55 & 10.0 & 43.20 & 136.40 & 350 & 4.4 & \\
\hline 2498 & 1987 & 7 & 1 & 3 & 32 & 28.3 & 55.73 & 135.51 & 11 & 3.4 & 10.2 \\
\hline 2499 & 1987 & 7 & 1 & 11 & 52 & 34.7 & 52.01 & 132.93 & 6 & 3.5 & 10.3 \\
\hline 2506 & 1987 & 7 & 31 & 12 & 55 & 24.9 & 48.72 & 131.97 & 8 & 4.1 & 11.3 \\
\hline 2511 & 1987 & 8 & 8 & 0 & 9 & 54.7 & 50.93 & 131.96 & 10 & 4.6 & 12.5 \\
\hline 2512 & 1987 & 8 & 8 & 3 & 37 & 38.5 & 51.14 & 131.84 & 10 & 3.4 & 10.1 \\
\hline 2517 & 1987 & 8 & 21 & 7 & 7 & 8.3 & 53.45 & 132.11 & 8 & 4.4 & 12.3 \\
\hline 2519 & 1987 & 8 & 21 & 19 & 33 & 18.2 & 53.48 & 132.08 & 9 & 3.6 & 10.4 \\
\hline 2536 & 1987 & 9 & 23 & 17 & 43 & 1.8 & 52.97 & 138.78 & 9 & 3.6 & 10.5 \\
\hline 2556 & 1987 & 10 & 30 & 21 & 42 & 46.0 & 48.91 & 129.97 & 8 & 3.3 & 10.0 \\
\hline 2560 & 1987 & 11 & 2 & 23 & 21 & 4.7 & 54.90 & 136.41 & 13 & 3.8 & 10.8 \\
\hline 2563 & 1987 & 11 & 8 & 6 & 44 & 7.5 & 52.36 & 132.71 & 10 & 3.7 & 10.7 \\
\hline 2568 & 1987 & 11 & 15 & 19 & 51 & 21.1 & 51.53 & 138.10 & 11 & 4.1 & 11.4 \\
\hline 2570 & 1987 & 11 & 21 & 13 & 48 & 56.4 & 43.06 & 131.19 & 550 & 4.5 & \\
\hline 2621 & 1988 & 2 & 19 & 20 & 41 & 6.6 & 52.95 & 138.62 & 12 & 3.4 & 10.1 \\
\hline 2629 & 1988 & 2 & 27 & 2 & 7 & 28.9 & 54.30 & 124.23 & 6 & 3.7 & 10.7 \\
\hline 2641 & 1988 & 3 & 11 & 11 & 40 & 41.7 & 53.48 & 140.73 & 10 & 3.6 & 8.5 \\
\hline 2644 & 1988 & 3 & 15 & 19 & 10 & 36.5 & 52.66 & 134.53 & 6 & 3.4 & 10.2 \\
\hline 2646 & 1988 & 3 & 21 & 11 & 29 & 8.7 & 51.30 & 131.48 & 20 & 3.3 & 10.0 \\
\hline 2679 & 1988 & 5 & 18 & 8 & 0 & 53.7 & 47.68 & 139.70 & 547 & 5.3 & \\
\hline 2692 & 1988 & 6 & 19 & 11 & 53 & 21.5 & 55.85 & 128.78 & 10 & 3.7 & 10.6 \\
\hline 2723 & 1988 & 8 & 10 & 5 & 16 & 8.9 & 49.49 & 130.19 & 12 & 3.9 & 11.0 \\
\hline 2724 & 1988 & 8 & 11 & 2 & 30 & 36.2 & 47.78 & 130.68 & 12 & 3.7 & 10.7 \\
\hline 2728 & 1988 & 8 & 23 & 20 & 57 & 50.0 & 43.20 & 136.30 & 325 & 4.4 & \\
\hline 2733 & 1988 & 8 & 30 & 12 & 58 & 55.5 & 53.91 & 137.64 & 10 & 4.7 & 11.0 \\
\hline 2750 & 1988 & 9 & 23 & 8 & 32 & 22.4 & 55.17 & 137.25 & 15 & 3.4 & 10.1 \\
\hline 2754 & 1988 & 9 & 30 & 3 & 9 & 7.1 & 54.18 & 137.71 & 10 & 3.7 & 10.7 \\
\hline 2764 & 1988 & 10 & 17 & 14 & 11 & 50.4 & 44.92 & 132.39 & 10 & 3.4 & 10.1 \\
\hline 2766 & 1988 & 10 & 20 & 20 & 2 & 33.2 & 44.89 & 131.99 & 10 & 3.4 & 10.1 \\
\hline 2769 & 1988 & 10 & 24 & 7 & 15 & 30.7 & 54.86 & 133.04 & 12 & 5.5 & 10.9 \\
\hline 2774 & 1988 & 11 & 5 & 22 & 26 & 43.7 & 46.42 & 136.40 & 443 & 3.4 & \\
\hline 2791 & 1988 & 12 & 2 & 23 & 32 & 56.6 & 53.92 & 126.44 & 11 & 3.7 & 10.7 \\
\hline 2800 & 1988 & 12 & 22 & 20 & 10 & 14.7 & 52.33 & 134.35 & 11 & 3.3 & 10.0 \\
\hline 2807 & 1989 & 1 & 13 & 12 & 52 & 14.5 & 49.04 & 131.70 & 18 & 3.8 & 10.8 \\
\hline 2829 & 1989 & 2 & 18 & 5 & 44 & 44.2 & 48.50 & 131.45 & 30 & 3.3 & 9.9 \\
\hline 2871 & 1989 & 4 & 30 & 16 & 26 & 45.0 & 43.40 & 135.90 & 345 & 3.3 & \\
\hline 2872 & 1989 & 4 & 30 & 19 & 7 & 28.0 & 43.80 & 134.00 & 460 & 3.9 & \\
\hline 2916 & 1989 & 7 & 23 & 12 & 1 & 30.4 & 54.52 & 124.89 & 13 & 5.3 & 13.5 \\
\hline 2920 & 1989 & 7 & 23 & 14 & 32 & 59.9 & 54.56 & 124.89 & 10 & 3.5 & 10.3 \\
\hline 2923 & 1989 & 7 & 24 & 1 & 35 & 23.5 & 54.52 & 124.92 & 10 & 3.3 & 10.0 \\
\hline
\end{tabular}


Приложение 1А. Каталог землетрясений региона Приамурье и Приморье 1865-2015 гг. магнитудой М 23.3.

\begin{tabular}{|c|c|c|c|c|c|c|c|c|c|c|c|}
\hline № & & Іата & & & $t_{0}$ & & ЭПи & нтр & $h$ & & \\
\hline$\Pi / \Pi$ & $\Gamma$ & $\mathrm{M}$ & д & ч & мин & $\mathrm{c}$ & $\varphi^{\circ}, \mathrm{N}$ & $\lambda^{\circ}, \mathrm{E}$ & км & $M / M L H$ & $K \mathrm{p}$ \\
\hline 2931 & 1989 & 7 & 31 & 0 & 27 & 1.2 & 54.38 & 123.03 & 11 & 3.6 & 10.4 \\
\hline 2933 & 1989 & 8 & 3 & 21 & 46 & 20.0 & 54.08 & 136.76 & 13 & 3.8 & 10.9 \\
\hline 2935 & 1989 & 8 & 8 & 16 & 25 & 49.3 & 45.39 & 130.84 & 15 & 3.4 & 10.2 \\
\hline 2958 & 1989 & 9 & 19 & 22 & 44 & 27.3 & 54.39 & 129.49 & 7 & 3.3 & 10.0 \\
\hline 2985 & 1989 & 11 & 10 & 8 & 55 & 57.7 & 48.88 & 131.45 & 10 & 3.5 & 10.3 \\
\hline 2996 & 1989 & 12 & 8 & 9 & 57 & 28.1 & 54.89 & 134.84 & 10 & 4.2 & 11.4 \\
\hline 3006 & 1989 & 12 & 23 & 1 & 24 & 25.3 & 54.13 & 121.97 & 11 & 3.7 & 10.6 \\
\hline 3021 & 1990 & 1 & 14 & 16 & 7 & 32.9 & 50.26 & 125.53 & 11 & 3.6 & 10.5 \\
\hline 3092 & 1990 & 4 & 21 & 22 & 56 & 55.0 & 47.50 & 139.00 & 506 & 6.0 & \\
\hline 3093 & 1990 & 4 & 24 & 16 & 31 & 47.0 & 42.50 & 132.10 & 555 & 4.0 & \\
\hline 3097 & 1990 & 4 & 27 & 10 & 12 & 27.1 & 50.63 & 132.55 & 15 & 3.3 & 10.0 \\
\hline 3101 & 1990 & 5 & 5 & 13 & 10 & 28.4 & 46.77 & 129.78 & 10 & 4.3 & 11.8 \\
\hline 3115 & 1990 & 6 & 2 & 17 & 11 & 21.7 & 55.60 & 130.65 & 12 & 4.3 & 11.8 \\
\hline 3127 & 1990 & 6 & 21 & 16 & 55 & 56.5 & 43.20 & 134.25 & 440 & 4.0 & \\
\hline 3144 & 1990 & 7 & 17 & 3 & 37 & 25.9 & 48.68 & 131.97 & 12 & 4.6 & 12.3 \\
\hline 3145 & 1990 & 7 & 17 & 4 & 1 & 11.6 & 48.69 & 131.98 & 13 & 3.9 & 11.0 \\
\hline 3167 & 1990 & 8 & 10 & 22 & 41 & 20.5 & 47.13 & 130.04 & 10 & 3.3 & 10.0 \\
\hline 3191 & 1990 & 9 & 1 & 21 & 56 & 7.3 & 54.24 & 125.98 & 5 & 3.3 & 9.9 \\
\hline 3207 & 1990 & 10 & 16 & 12 & 4 & 26.7 & 49.83 & 129.53 & 12 & 4.2 & 11.5 \\
\hline 3208 & 1990 & 10 & 16 & 23 & 27 & 40.5 & 55.22 & 138.98 & 12 & 3.6 & 10.5 \\
\hline 3226 & 1990 & 11 & 13 & 2 & 35 & 3.5 & 45.90 & 138.92 & 16 & 6.2 & 15.2 \\
\hline 3227 & 1990 & 11 & 13 & 3 & 2 & 7.1 & 45.74 & 139.06 & 15 & 3.3 & 10.0 \\
\hline 3242 & 1990 & 11 & 14 & 8 & 23 & 22.4 & 46.02 & 138.66 & 10 & 3.3 & 9.9 \\
\hline 3250 & 1990 & 11 & 14 & 14 & 43 & 34.4 & 46.01 & 138.85 & 16 & 4.9 & 12.8 \\
\hline 3253 & 1990 & 11 & 14 & 15 & 37 & 45.7 & 45.95 & 138.82 & 16 & 4.2 & 11.6 \\
\hline 3332 & 1990 & 12 & 8 & 13 & 52 & 11.1 & 46.01 & 138.82 & 10 & 3.3 & 9.9 \\
\hline 3348 & 1990 & 12 & 17 & 12 & 28 & 20.1 & 45.14 & 138.72 & 10 & 3.3 & 10.0 \\
\hline 3358 & 1990 & 12 & 25 & 10 & 27 & 36.8 & 45.99 & 138.89 & 10 & 3.5 & 10.3 \\
\hline 3375 & 1991 & 1 & 26 & 16 & 17 & 14.9 & 54.10 & 134.61 & 10 & 3.3 & 10.0 \\
\hline 3376 & 1991 & 1 & 27 & 15 & 34 & 6.0 & 43.45 & 136.10 & 320 & 4.7 & \\
\hline 3391 & 1991 & 2 & 12 & 7 & 14 & 50.2 & 55.95 & 124.25 & 10 & 3.3 & 10.0 \\
\hline 3432 & 1991 & 4 & 14 & 6 & 36 & 22.1 & 43.50 & 134.20 & 453 & 4.3 & \\
\hline 3444 & 1991 & 4 & 29 & 16 & 51 & 26.5 & 43.55 & 132.53 & 489 & 4.7 & \\
\hline 3457 & 1991 & 5 & 19 & 16 & 17 & 47.5 & 54.58 & 125.27 & 10 & 4.3 & 11.7 \\
\hline 3461 & 1991 & 5 & 21 & 5 & 30 & 25.0 & 52.48 & 132.58 & 10 & 4.2 & 11.5 \\
\hline 3467 & 1991 & 6 & 3 & 6 & 47 & 38.2 & 45.90 & 138.61 & 10 & 3.4 & 10.2 \\
\hline 3469 & 1991 & 6 & 5 & 10 & 21 & 26.5 & 51.24 & 133.53 & 10 & 3.3 & 10.0 \\
\hline 3473 & 1991 & 6 & 9 & 19 & 23 & 29.7 & 48.10 & 129.45 & 10 & 4.2 & 12.0 \\
\hline 3480 & 1991 & 6 & 20 & 9 & 17 & 32.0 & 55.82 & 136.78 & 10 & 3.6 & 10.5 \\
\hline 3483 & 1991 & 6 & 21 & 11 & 4 & 25.4 & 55.82 & 124.30 & 10 & 3.4 & 10.2 \\
\hline 3490 & 1991 & 6 & 28 & 11 & 20 & 44.8 & 51.77 & 132.46 & 12 & 4.0 & 11.2 \\
\hline 3496 & 1991 & 7 & 17 & 10 & 52 & 43.1 & 49.80 & 132.40 & 10 & 3.4 & 10.1 \\
\hline 3500 & 1991 & 7 & 22 & 12 & 5 & 27.8 & 55.67 & 131.11 & 10 & 3.6 & 10.5 \\
\hline
\end{tabular}


Приложение 1А. Каталог землетрясений региона Приамурье и Приморье 1865-2015 гг. магнитудой М $\geq 3.3$.

\begin{tabular}{|c|c|c|c|c|c|c|c|c|c|c|c|}
\hline \multirow{2}{*}{$\begin{array}{c}\text { № } \\
\text { ח/ח }\end{array}$} & \multicolumn{3}{|c|}{ Дата } & \multicolumn{3}{|c|}{$t_{0}$} & \multicolumn{2}{|c|}{ Эпицентр } & \multirow{2}{*}{$\begin{array}{c}h \\
\text { км }\end{array}$} & \multirow[b]{2}{*}{$M / M L H$} & \multirow[b]{2}{*}{$K \mathrm{p}$} \\
\hline & $\Gamma$ & $\mathrm{M}$ & д & ч & мин & $\mathrm{c}$ & $\varphi^{\circ}, \mathrm{N}$ & $\lambda^{\circ}, \mathrm{E}$ & & & \\
\hline 3505 & 1991 & 8 & 9 & 4 & 53 & 31.6 & 46.00 & 138.65 & 11 & 4.0 & 11.2 \\
\hline 3506 & 1991 & 8 & 16 & 16 & 39 & 23.0 & 51.67 & 133.08 & 10 & 3.4 & 10.2 \\
\hline 3514 & 1991 & 9 & 5 & 18 & 27 & 31.4 & 49.09 & 131.62 & 10 & 3.4 & 10.2 \\
\hline 3522 & 1991 & 10 & 7 & 4 & 41 & 13.4 & 53.28 & 134.90 & 10 & 3.7 & 10.7 \\
\hline 3527 & 1991 & 11 & 3 & 1 & 3 & 12.1 & 54.61 & 135.62 & 10 & 3.4 & 10.1 \\
\hline 3550 & 1991 & 12 & 28 & 0 & 14 & 45.1 & 52.70 & 139.17 & 11 & 3.9 & 11.1 \\
\hline 3559 & 1992 & 1 & 12 & 22 & 11 & 19.0 & 46.32 & 129.29 & 10 & 3.3 & 10.0 \\
\hline 3560 & 1992 & 1 & 14 & 9 & 35 & 26.9 & 54.43 & 135.35 & 10 & 3.6 & 10.5 \\
\hline 3575 & 1992 & 2 & 2 & 15 & 24 & 47.9 & 55.62 & 130.64 & 7 & 3.3 & 9.9 \\
\hline 3628 & 1992 & 5 & 6 & 4 & 13 & 51.1 & 53.63 & 125.49 & 12 & 3.4 & 10.1 \\
\hline 3660 & 1992 & 7 & 9 & 21 & 52 & 51.1 & 55.18 & 123.33 & 7 & 4.0 & 11.2 \\
\hline 3661 & 1992 & 7 & 11 & 1 & 36 & 44.6 & 54.11 & 127.40 & 7 & 3.4 & 10.1 \\
\hline 3666 & 1992 & 7 & 15 & 9 & 12 & 58.5 & 43.45 & 132.54 & 540 & 4.5 & \\
\hline 3667 & 1992 & 7 & 16 & 5 & 3 & 42.6 & 52.82 & 137.26 & 7 & 3.9 & 11.0 \\
\hline 3669 & 1992 & 7 & 21 & 16 & 33 & 26.5 & 54.13 & 131.03 & 8 & 4.2 & 11.5 \\
\hline 3672 & 1992 & 8 & 1 & 19 & 22 & 8.9 & 43.53 & 132.60 & 511 & 3.3 & \\
\hline 3673 & 1992 & 8 & 4 & 12 & 9 & 31.3 & 55.49 & 130.47 & 8 & 3.7 & 10.6 \\
\hline 3674 & 1992 & 8 & 10 & 2 & 27 & 56.9 & 49.05 & 131.97 & 10 & 3.4 & 10.1 \\
\hline 3675 & 1992 & 8 & 11 & 9 & 34 & 19.5 & 43.50 & 135.70 & 360 & 6.2 & \\
\hline 3684 & 1992 & 8 & 30 & 11 & 2 & 3.7 & 48.66 & 129.61 & 12 & 4.2 & 11.6 \\
\hline 3691 & 1992 & 9 & 12 & 3 & 36 & 47.0 & 49.52 & 126.19 & 10 & 3.9 & 11.1 \\
\hline 3712 & 1992 & 11 & 7 & 3 & 46 & 46.8 & 54.94 & 135.18 & 7 & 3.8 & 10.8 \\
\hline 3730 & 1992 & 12 & 17 & 4 & 29 & 8.0 & 44.40 & 137.20 & 10 & 4.7 & \\
\hline 3739 & 1993 & 1 & 1 & 23 & 5 & 20.2 & 49.19 & 136.41 & 7 & 3.5 & 10.3 \\
\hline 3741 & 1993 & 1 & 4 & 9 & 7 & 21.3 & 52.75 & 134.62 & 10 & 3.7 & 10.7 \\
\hline 3742 & 1993 & 1 & 8 & 16 & 25 & 30.2 & 55.52 & 123.78 & 6 & 3.4 & 10.2 \\
\hline 3766 & 1993 & 2 & 22 & 8 & 45 & 3.6 & 55.28 & 123.66 & 10 & 3.3 & 10.0 \\
\hline 3768 & 1993 & 2 & 25 & 7 & 40 & 19.6 & 55.34 & 123.84 & 5 & 3.8 & 10.8 \\
\hline 3770 & 1993 & 3 & 1 & 14 & 7 & 38.0 & 42.83 & 131.37 & 575 & 3.7 & \\
\hline 3783 & 1993 & 3 & 31 & 3 & 48 & 51.3 & 51.32 & 132.79 & 7 & 3.4 & 10.1 \\
\hline 3810 & 1993 & 5 & 31 & 1 & 59 & 16.9 & 50.78 & 126.60 & 7 & 3.3 & 9.9 \\
\hline 3814 & 1993 & 6 & 12 & 16 & 4 & 7.6 & 54.86 & 136.47 & 12 & 4.0 & 11.6 \\
\hline 3816 & 1993 & 6 & 20 & 17 & 46 & 19.6 & 55.24 & 122.18 & 10 & 3.9 & 10.7 \\
\hline 3823 & 1993 & 7 & 14 & 21 & 53 & 44.0 & 42.38 & 133.07 & 480 & 4.5 & \\
\hline 3837 & 1993 & 10 & 1 & 22 & 40 & 6.2 & 47.68 & 130.46 & 12 & 5.0 & 12.9 \\
\hline 3844 & 1993 & 10 & 14 & 6 & 5 & 9.1 & 55.30 & 128.91 & 7 & 4.4 & 12.4 \\
\hline 3851 & 1993 & 10 & 25 & 21 & 34 & 42.2 & 55.60 & 134.66 & 8 & 3.5 & 10.3 \\
\hline 3855 & 1993 & 11 & 2 & 7 & 14 & 51.0 & 42.77 & 131.16 & 570 & 4.8 & \\
\hline 3878 & 1994 & 1 & 4 & 20 & 0 & 26.4 & 53.31 & 132.00 & 7 & 3.9 & 11.0 \\
\hline 3880 & 1994 & 1 & 5 & 23 & 57 & 7.6 & 47.63 & 131.06 & 5 & 3.6 & 10.4 \\
\hline 3883 & 1994 & 1 & 11 & 19 & 30 & 1.3 & 51.03 & 137.28 & 7 & 3.3 & 10.0 \\
\hline 3890 & 1994 & 1 & 26 & 12 & 14 & 3.3 & 50.57 & 131.53 & 7 & 4.1 & 11.4 \\
\hline 3891 & 1994 & 1 & 28 & 1 & 5 & 14.0 & 54.78 & 135.17 & 12 & 4.7 & 12.2 \\
\hline
\end{tabular}


Приложение 1А. Каталог землетрясений региона Приамурье и Приморье 1865-2015 гг. магнитудой М 23.3.

\begin{tabular}{|c|c|c|c|c|c|c|c|c|c|c|c|}
\hline № & & ата & & & $t_{0}$ & & Эпи & нтр & $h$ & & \\
\hline$\Pi / \Pi$ & $\Gamma$ & $\mathrm{M}$ & д & ч & мин & $\mathrm{c}$ & $\varphi^{\circ}, \mathrm{N}$ & $\lambda^{\circ}, \mathrm{E}$ & км & $M / M L H$ & $K \mathrm{p}$ \\
\hline 3892 & 1994 & 1 & 31 & 0 & 25 & 5.8 & 54.76 & 135.07 & 10 & 4.0 & 11.2 \\
\hline 3895 & 1994 & 2 & 8 & 5 & 18 & 27.0 & 43.30 & 130.86 & 565 & 4.7 & \\
\hline 3897 & 1994 & 2 & 13 & 4 & 20 & 32.3 & 53.53 & 139.25 & 7 & 3.9 & 11.0 \\
\hline 3904 & 1994 & 3 & 1 & 17 & 48 & 8.3 & 55.01 & 138.53 & 7 & 3.7 & 10.8 \\
\hline 3933 & 1994 & 4 & 9 & 16 & 20 & 44.8 & 53.34 & 133.17 & 10 & 3.6 & 10.6 \\
\hline 3936 & 1994 & 4 & 15 & 21 & 13 & 37.8 & 50.82 & 135.16 & 7 & 4.2 & 11.3 \\
\hline 3940 & 1994 & 4 & 19 & 21 & 16 & 53.9 & 54.92 & 123.96 & 7 & 4.1 & 11.3 \\
\hline 3955 & 1994 & 5 & 5 & 3 & 36 & 37.1 & 51.59 & 133.45 & 7 & 4.7 & 12.7 \\
\hline 3961 & 1994 & 5 & 10 & 13 & 39 & 6.8 & 54.19 & 122.93 & 8 & 3.4 & 10.2 \\
\hline 3968 & 1994 & 5 & 25 & 12 & 20 & 50.1 & 52.49 & 134.48 & 7 & 3.3 & 10.0 \\
\hline 3970 & 1994 & 5 & 27 & 23 & 53 & 34.1 & 54.95 & 135.37 & 7 & 3.5 & 10.3 \\
\hline 3977 & 1994 & 6 & 4 & 19 & 36 & 10.4 & 48.92 & 129.92 & 10 & 4.6 & 12.1 \\
\hline 3978 & 1994 & 6 & 5 & 6 & 51 & 33.0 & 49.05 & 129.75 & 10 & 3.9 & 10.9 \\
\hline 3979 & 1994 & 6 & 6 & 3 & 25 & 5.4 & 54.08 & 130.00 & 7 & 4.0 & 11.2 \\
\hline 3988 & 1994 & 6 & 16 & 12 & 9 & 22.4 & 49.87 & 135.74 & 10 & 3.3 & 9.9 \\
\hline 4014 & 1994 & 7 & 21 & 18 & 36 & 31.0 & 42.22 & 133.16 & 495 & 6.8 & \\
\hline 4016 & 1994 & 7 & 24 & 7 & 37 & 7.3 & 42.28 & 133.12 & 474 & 4.3 & \\
\hline 4021 & 1994 & 8 & 1 & 22 & 23 & 13.1 & 48.17 & 129.78 & 15 & 3.7 & 10.6 \\
\hline 4031 & 1994 & 8 & 24 & 22 & 21 & 7.9 & 50.17 & 133.90 & 7 & 4.2 & 11.5 \\
\hline 4045 & 1994 & 9 & 19 & 7 & 18 & 29.0 & 44.80 & 137.60 & 325 & 4.4 & \\
\hline 4053 & 1994 & 10 & 15 & 23 & 31 & 3.9 & 41.70 & 131.40 & 562 & 4.1 & \\
\hline 4057 & 1994 & 10 & 21 & 14 & 38 & 54.3 & 48.91 & 129.65 & 10 & 3.4 & 10.1 \\
\hline 4070 & 1994 & 11 & 28 & 4 & 57 & 54.0 & 43.24 & 130.93 & 547 & 4.3 & \\
\hline 4092 & 1995 & 1 & 14 & 15 & 47 & 17.3 & 42.14 & 134.06 & 446 & 4.3 & \\
\hline 4119 & 1995 & 3 & 1 & 17 & 29 & 26.7 & 51.73 & 125.49 & 7 & 3.5 & 10.3 \\
\hline 4132 & 1995 & 3 & 27 & 21 & 20 & 0.2 & 54.17 & 126.22 & 10 & 3.4 & 10.1 \\
\hline 4138 & 1995 & 3 & 30 & 22 & 15 & 50.0 & 44.73 & 137.49 & 350 & 6.3 & \\
\hline 4144 & 1995 & 4 & 6 & 12 & 42 & 26.5 & 49.08 & 126.38 & 10 & 3.7 & 10.7 \\
\hline 4177 & 1995 & 6 & 9 & 8 & 16 & 14.4 & 55.40 & 131.00 & 7 & 3.3 & 10.0 \\
\hline 4179 & 1995 & 6 & 13 & 10 & 8 & 47.5 & 55.60 & 123.41 & 6 & 3.9 & 11.1 \\
\hline 4182 & 1995 & 6 & 15 & 20 & 12 & 25.8 & 51.98 & 135.19 & 10 & 3.3 & 9.9 \\
\hline 4190 & 1995 & 6 & 27 & 12 & 43 & 28.9 & 55.67 & 130.68 & 10 & 3.9 & 11.0 \\
\hline 4197 & 1995 & 7 & 16 & 8 & 22 & 5.1 & 50.41 & 136.94 & 17 & 3.3 & 9.9 \\
\hline 4231 & 1995 & 10 & 17 & 7 & 16 & 45.1 & 48.70 & 131.13 & 7 & 3.7 & 11.4 \\
\hline 4232 & 1995 & 10 & 18 & 4 & 27 & 53.4 & 42.05 & 131.91 & 557 & 4.2 & \\
\hline 4233 & 1995 & 10 & 20 & 7 & 49 & 31.5 & 42.51 & 131.92 & 503 & 4.7 & \\
\hline 4237 & 1995 & 10 & 21 & 16 & 52 & 24.1 & 49.00 & 131.42 & 10 & 3.4 & 10.2 \\
\hline 4243 & 1995 & 10 & 28 & 17 & 57 & 32.7 & 50.44 & 128.82 & 7 & 3.6 & 10.5 \\
\hline 4260 & 1995 & 12 & 18 & 5 & 41 & 41.3 & 52.39 & 132.07 & 7 & 3.4 & 10.1 \\
\hline 4286 & 1996 & 2 & 22 & 16 & 25 & 24.4 & 50.15 & 125.69 & 12 & 3.8 & 10.9 \\
\hline 4290 & 1996 & 3 & 1 & 7 & 46 & 38.8 & 54.33 & 125.92 & 7 & 3.7 & 10.6 \\
\hline 4298 & 1996 & 3 & 13 & 0 & 47 & 41.4 & 41.96 & 131.29 & 564 & 4.1 & \\
\hline 4310 & 1996 & 4 & 3 & 11 & 48 & 26.3 & 53.41 & 138.99 & 10 & 3.3 & 10.0 \\
\hline
\end{tabular}


Приложение 1А. Каталог землетрясений региона Приамурье и Приморье 1865-2015 гг. магнитудой М $\geq 3.3$.

\begin{tabular}{|c|c|c|c|c|c|c|c|c|c|c|c|}
\hline № & & ата & & & $t_{0}$ & & Эпи & нтр & $h$ & & \\
\hline$\Pi / \Pi$ & $\Gamma$ & $\mathrm{M}$ & д & ч & мин & $\mathrm{c}$ & $\varphi^{\circ}, \mathrm{N}$ & $\lambda^{\circ}, \mathrm{E}$ & км & $M / M L H$ & $K p$ \\
\hline 4316 & 1996 & 4 & 15 & 7 & 27 & 35.5 & 44.34 & 133.49 & 460 & 3.3 & \\
\hline 4318 & 1996 & 4 & 20 & 1 & 42 & 20.1 & 48.09 & 130.10 & 10 & 3.3 & 9.9 \\
\hline 4339 & 1996 & 5 & 21 & 5 & 43 & 18.6 & 53.68 & 122.70 & 10 & 4.3 & 11.4 \\
\hline 4345 & 1996 & 6 & 4 & 20 & 22 & 2.0 & 43.38 & 132.37 & 515 & 5.1 & \\
\hline 4353 & 1996 & 6 & 12 & 17 & 55 & 48.9 & 54.22 & 126.35 & 7 & 3.8 & 11.1 \\
\hline 4357 & 1996 & 6 & 23 & 20 & 16 & 13.0 & 50.13 & 131.30 & 7 & 3.5 & 10.3 \\
\hline 4379 & 1996 & 8 & 10 & 15 & 4 & 42.6 & 52.37 & 132.68 & 10 & 3.3 & 9.9 \\
\hline 4384 & 1996 & 8 & 20 & 0 & 38 & 41.8 & 50.91 & 135.25 & 10 & 3.3 & 9.9 \\
\hline 4400 & 1996 & 9 & 9 & 12 & 38 & 26.5 & 50.15 & 135.93 & 7 & 3.4 & 10.2 \\
\hline 4422 & 1996 & 11 & 9 & 19 & 59 & 49.7 & 50.90 & 135.45 & 9 & 3.9 & 11.0 \\
\hline 4483 & 1997 & 3 & 31 & 2 & 55 & 56.5 & 48.72 & 131.02 & 15 & 4.2 & 11.6 \\
\hline 4496 & 1997 & 4 & 21 & 4 & 24 & 11.5 & 54.19 & 124.03 & 8 & 3.7 & 10.6 \\
\hline 4499 & 1997 & 4 & 27 & 17 & 25 & 4.4 & 50.04 & 135.96 & 10 & 3.3 & 10.0 \\
\hline 4502 & 1997 & 4 & 30 & 13 & 57 & 5 & 44.69 & 130.65 & 600 & 4.1 & \\
\hline 4503 & 1997 & 5 & 4 & 3 & 26 & 28 & 43.44 & 135.55 & 360 & 3.3 & \\
\hline 4506 & 1997 & 5 & 10 & 14 & 32 & 58.9 & 54.31 & 122.83 & 10 & 3.4 & 10.1 \\
\hline 4513 & 1997 & 6 & 4 & 21 & 19 & 27.8 & 55.16 & 123.96 & 13 & 4.2 & 11.5 \\
\hline 4522 & 1997 & 6 & 29 & 11 & 12 & 19.2 & 55.13 & 125.06 & 7 & 3.7 & 10.6 \\
\hline 4527 & 1997 & 7 & 5 & 10 & 11 & 30.5 & 51.43 & 132.15 & 7 & 3.5 & 10.3 \\
\hline 4528 & 1997 & 7 & 6 & 1 & 51 & 48 & 42.80 & 131.39 & 557 & 5.6 & \\
\hline 4549 & 1997 & 8 & 30 & 4 & 54 & 49 & 43.49 & 135.71 & 354 & 5.3 & \\
\hline 4559 & 1997 & 10 & 1 & 6 & 5 & 49 & 46.25 & 136.14 & 410 & 5.2 & \\
\hline 4562 & 1997 & 10 & 17 & 18 & 37 & 45.2 & 52.51 & 134.87 & 12 & 3.3 & 10.0 \\
\hline 4578 & 1997 & 11 & 5 & 8 & 24 & 38.7 & 56.03 & 133.76 & 7 & 3.9 & 11.0 \\
\hline 4581 & 1997 & 11 & 10 & 17 & 47 & 21.2 & 55.12 & 123.92 & 6 & 4.6 & 12.2 \\
\hline 4590 & 1997 & 12 & 7 & 18 & 55 & 4.1 & 54.03 & 134.07 & 8 & 3.6 & 10.4 \\
\hline 4593 & 1997 & 12 & 23 & 15 & 2 & 24.9 & 55.09 & 123.88 & 9 & 3.6 & 10.4 \\
\hline 4606 & 1998 & 1 & 12 & 19 & 36 & 16.40 & 43.50 & 134.06 & 430 & 4.0 & \\
\hline 4607 & 1998 & 1 & 12 & 21 & 47 & 21.20 & 47.81 & 130.56 & 14 & 3.5 & 10.3 \\
\hline 4609 & 1998 & 1 & 18 & 0 & 26 & 42.00 & 44.10 & 132.48 & 529 & 4.0 & \\
\hline 4616 & 1998 & 1 & 31 & 3 & 5 & 17.90 & 43.25 & 134.27 & 390 & 4.1 & \\
\hline 4661 & 1998 & 4 & 3 & 2 & 35 & 46.10 & 48.03 & 133.05 & 10 & 3.6 & 10.5 \\
\hline 4664 & 1998 & 4 & 4 & 4 & 45 & 47.80 & 51.66 & 133.80 & 7 & 3.3 & 9.9 \\
\hline 4692 & 1998 & 4 & 21 & 2 & 11 & 37.90 & 51.35 & 133.56 & 7 & 3.7 & 10.6 \\
\hline 4695 & 1998 & 4 & 25 & 11 & 0 & 49.50 & 44.97 & 137.30 & 311 & 4.1 & \\
\hline 4722 & 1998 & 5 & 24 & 12 & 32 & 31.00 & 43.18 & 134.24 & 444 & 3.6 & \\
\hline 4730 & 1998 & 5 & 30 & 8 & 50 & 51.70 & 51.91 & 134.56 & 9 & 3.7 & 10.6 \\
\hline 4777 & 1998 & 7 & 13 & 16 & 40 & 16.40 & 43.45 & 133.45 & 423 & 3.6 & \\
\hline 4789 & 1998 & 7 & 24 & 23 & 12 & 16.70 & 48.88 & 131.47 & 15 & 4.7 & 13.2 \\
\hline 4790 & 1998 & 7 & 24 & 23 & 19 & 44.10 & 48.74 & 131.43 & 13 & 4.6 & 12.6 \\
\hline 4798 & 1998 & 8 & 2 & 21 & 2 & 44.00 & 45.27 & 137.24 & 348 & 4.0 & \\
\hline 4800 & 1998 & 8 & 8 & 22 & 43 & 45.80 & 53.91 & 132.00 & 8 & 3.6 & 10.3 \\
\hline 4810 & 1998 & 8 & 14 & 14 & 27 & 16.30 & 53.93 & 131.97 & 9 & 4.1 & 10.8 \\
\hline
\end{tabular}


Приложение 1А. Каталог землетрясений региона Приамурье и Приморье 1865-2015 гг. магнитудой М $\geq 3.3$.

\begin{tabular}{|c|c|c|c|c|c|c|c|c|c|c|c|}
\hline № & & Іата & & & $t_{0}$ & & ЭПи & нтр & $h$ & & \\
\hline$\Pi / \Pi$ & $\Gamma$ & $\mathrm{M}$ & д & ч & мин & $\mathrm{c}$ & $\varphi^{\circ}, \mathrm{N}$ & $\lambda^{\circ}, \mathrm{E}$ & км & $M / M L H$ & $K \mathrm{p}$ \\
\hline 4811 & 1998 & 8 & 14 & 20 & 45 & 0.50 & 53.97 & 132.05 & 9 & 3.5 & 10.4 \\
\hline 4822 & 1998 & 8 & 20 & 9 & 36 & 36.00 & 45.60 & 136.91 & 356 & 5.5 & \\
\hline 4834 & 1998 & 9 & 6 & 3 & 55 & 12.40 & 46.32 & 136.10 & 450 & 3.5 & \\
\hline 4870 & 1998 & 10 & 15 & 11 & 3 & 5.10 & 49.16 & 131.84 & 10 & 3.7 & 10.7 \\
\hline 4882 & 1998 & 10 & 27 & 21 & 32 & 42.70 & 43.06 & 133.69 & 307 & 3.8 & \\
\hline 4890 & 1998 & 11 & 5 & 22 & 26 & 43.70 & 46.42 & 136.40 & 443 & 4.1 & \\
\hline 4896 & 1998 & 11 & 11 & 17 & 27 & 58.00 & 48.56 & 133.31 & 14 & 4.0 & 11.2 \\
\hline 4945 & 1998 & 12 & 25 & 16 & 36 & 8.00 & 42.24 & 134.33 & 415 & 4.3 & \\
\hline 5042 & 1999 & 4 & 8 & 13 & 10 & 34.5 & 43.60 & 130.64 & 572 & 7.6 & \\
\hline 5054 & 1999 & 4 & 19 & 10 & 0 & 23.0 & 51.80 & 125.46 & 7 & 3.3 & 9.9 \\
\hline 5065 & 1999 & 4 & 25 & 22 & 20 & 12.7 & 55.33 & 124.53 & 8 & 4.7 & 12.0 \\
\hline 5098 & 1999 & 5 & 13 & 0 & 39 & 8.0 & 43.52 & 134.10 & 412 & 4.0 & \\
\hline 5167 & 1999 & 7 & 2 & 17 & 5 & 22.6 & 51.28 & 122.63 & 12 & 3.7 & 10.6 \\
\hline 5172 & 1999 & 7 & 6 & 12 & 17 & 0.9 & 54.15 & 129.29 & 6 & 3.4 & 10.2 \\
\hline 5193 & 1999 & 7 & 25 & 6 & 55 & 2.3 & 55.22 & 122.39 & 19 & 3.4 & 10.1 \\
\hline 5214 & 1999 & 8 & 13 & 18 & 36 & 26.0 & 48.50 & 128.49 & 28 & 4.6 & 12.5 \\
\hline 5215 & 1999 & 8 & 14 & 0 & 4 & 41.3 & 48.59 & 128.69 & 8 & 3.8 & 10.8 \\
\hline 5224 & 1999 & 8 & 21 & 11 & 24 & 3.0 & 48.32 & 127.87 & 9 & 3.5 & 10.0 \\
\hline 5235 & 1999 & 9 & 3 & 11 & 23 & 28.2 & 48.92 & 131.39 & 10 & 4.0 & 11.5 \\
\hline 5249 & 1999 & 9 & 14 & 15 & 58 & 27.4 & 54.66 & 134.30 & 8 & 3.3 & 9.9 \\
\hline 5253 & 1999 & 9 & 18 & 11 & 28 & 47.3 & 54.21 & 129.99 & 6 & 3.7 & 10.7 \\
\hline 5256 & 1999 & 9 & 21 & 1 & 12 & 23.4 & 55.50 & 131.75 & 12 & 3.9 & 11.1 \\
\hline 5257 & 1999 & 9 & 21 & 1 & 13 & 17.5 & 55.44 & 131.73 & 5 & 3.4 & 10.1 \\
\hline 5315 & 1999 & 11 & 23 & 9 & 57 & 30.6 & 42.36 & 133.19 & 449 & 4.2 & \\
\hline 5323 & 1999 & 11 & 26 & 22 & 13 & 5.1 & 51.94 & 134.93 & 8 & 4.1 & 12.1 \\
\hline 5329 & 1999 & 12 & 2 & 7 & 51 & 44.5 & 55.63 & 130.45 & 8 & 3.5 & 10.3 \\
\hline 5338 & 1999 & 12 & 12 & 2 & 2 & 18.7 & 53.84 & 127.78 & 10 & 4.2 & 11.5 \\
\hline 5341 & 1999 & 12 & 14 & 6 & 2 & 29.5 & 55.34 & 132.66 & 8 & 3.9 & 11.1 \\
\hline 5361 & 1999 & 12 & 27 & 10 & 46 & 18.4 & 47.70 & 130.58 & 5 & 3.5 & 10.3 \\
\hline 5383 & 2000 & 1 & 18 & 10 & 41 & 35.6 & 54.90 & 123.39 & 8 & 3.5 & 10.3 \\
\hline 5385 & 2000 & 1 & 19 & 9 & 33 & 18.9 & 52.79 & 139.31 & 14 & 3.4 & 10.2 \\
\hline 5414 & 2000 & 2 & 13 & 2 & 57 & 10.0 & 42.92 & 131.87 & 529 & 6.3 & \\
\hline 5459 & 2000 & 3 & 19 & 13 & 48 & 31.0 & 43.58 & 135.83 & 353 & 4.1 & \\
\hline 5487 & 2000 & 4 & 4 & 20 & 35 & 32.3 & 51.86 & 132.71 & 8 & 3.8 & 11.5 \\
\hline 5499 & 2000 & 4 & 11 & 3 & 46 & 16.8 & 45.19 & 139.67 & 21 & 4.2 & 12.0 \\
\hline 5548 & 2000 & 5 & 13 & 21 & 59 & 27.7 & 47.88 & 130.88 & 9 & 3.6 & 10.4 \\
\hline 5550 & 2000 & 5 & 14 & 15 & 48 & 52.0 & 48.95 & 129.93 & 13 & 4.2 & 12.0 \\
\hline 5623 & 2000 & 7 & 4 & 4 & 49 & 22.8 & 49.90 & 132.00 & 11 & 3.4 & 10.1 \\
\hline 5697 & 2000 & 8 & 27 & 22 & 51 & 21.3 & 52.61 & 128.90 & 7 & 3.8 & 11.0 \\
\hline 5749 & 2000 & 10 & 18 & 5 & 34 & 12.2 & 48.86 & 131.64 & 18 & 3.4 & 10.1 \\
\hline 5764 & 2000 & 11 & 2 & 19 & 48 & 22.1 & 54.76 & 133.33 & 7 & 3.7 & 10.7 \\
\hline 5780 & 2000 & 11 & 10 & 4 & 45 & 58.0 & 42.09 & 133.61 & 452 & 4.1 & \\
\hline 5796 & 2000 & 11 & 17 & 17 & 29 & 47.0 & 55.34 & 122.14 & 16 & 3.9 & 11.0 \\
\hline
\end{tabular}


Приложение 1А. Каталог землетрясений региона Приамурье и Приморье 1865-2015 гг. магнитудой М $\geq 3.3$.

\begin{tabular}{|c|c|c|c|c|c|c|c|c|c|c|c|}
\hline \multirow{2}{*}{$\begin{array}{c}\text { № } \\
\Pi / \Pi\end{array}$} & \multicolumn{3}{|c|}{ Дата } & \multicolumn{3}{|c|}{$t_{0}$} & \multicolumn{2}{|c|}{ Эпицентр } & \multirow{2}{*}{$\begin{array}{c}h \\
\text { км }\end{array}$} & \multirow[b]{2}{*}{$M / M L H$} & \multirow[b]{2}{*}{$K \mathrm{p}$} \\
\hline & $\Gamma$ & $\mathrm{M}$ & д & ч & мин & $\mathrm{c}$ & $\varphi^{\circ}, \mathrm{N}$ & $\lambda^{\circ}, \mathrm{E}$ & & & \\
\hline 5839 & 2000 & 12 & 24 & 3 & 47 & 52.5 & 54.98 & 134.29 & 7 & 3.4 & 10.2 \\
\hline 5903 & 2001 & 2 & 21 & 2 & 44 & 55.8 & 53.95 & 128.21 & 18 & 3.4 & 10.2 \\
\hline 5904 & 2001 & 2 & 21 & 5 & 52 & 59.6 & 55.07 & 130.45 & 8 & 3.4 & 10.2 \\
\hline 5961 & 2001 & 4 & 8 & 5 & 9 & 31.7 & 55.41 & 133.01 & 20 & 4.6 & 12.2 \\
\hline 5962 & 2001 & 4 & 8 & 5 & 12 & 6.0 & 55.39 & 132.93 & 10 & 3.8 & 10.8 \\
\hline 5970 & 2001 & 4 & 11 & 7 & 52 & 7.5 & 43.80 & 132.96 & 527 & 3.7 & \\
\hline 5992 & 2001 & 4 & 24 & 14 & 35 & 38.3 & 47.66 & 131.03 & 10 & 3.3 & 9.9 \\
\hline 6020 & 2001 & 5 & 15 & 23 & 46 & 54.0 & 45.37 & 136.97 & 355 & 4.1 & \\
\hline 6031 & 2001 & 5 & 21 & 11 & 42 & 48.7 & 55.79 & 136.90 & 20 & 3.6 & 10.5 \\
\hline 6066 & 2001 & 6 & 20 & 13 & 57 & 43.0 & 54.96 & 135.05 & 9 & 4.1 & 11.9 \\
\hline 6086 & 2001 & 7 & 15 & 19 & 38 & 42.5 & 42.77 & 131.19 & 562 & 3.7 & \\
\hline 6141 & 2001 & 8 & 25 & 13 & 58 & 13.8 & 48.97 & 131.22 & 11 & 3.6 & 10.5 \\
\hline 6146 & 2001 & 9 & 3 & 3 & 9 & 35.4 & 48.26 & 133.15 & 13 & 3.6 & 10.4 \\
\hline 6149 & 2001 & 9 & 6 & 10 & 42 & 41.2 & 54.35 & 123.04 & 30 & 3.8 & 10.9 \\
\hline 6213 & 2001 & 10 & 28 & 16 & 21 & 5.1 & 52.14 & 133.39 & 16 & 3.8 & 10.9 \\
\hline 6247 & 2001 & 11 & 24 & 11 & 50 & 42.0 & 43.10 & 131.08 & 560 & 3.5 & \\
\hline 6319 & 2002 & 1 & 23 & 18 & 11 & 11.2 & 53.58 & 139.19 & 22 & 3.9 & 11.1 \\
\hline 6323 & 2002 & 1 & 27 & 18 & 20 & 33.9 & 53.72 & 125.59 & 11 & 3.3 & 9.9 \\
\hline 6333 & 2002 & 2 & 1 & 21 & 55 & 21.5 & 45.42 & 136.85 & 358 & 6.5 & \\
\hline 6482 & 2002 & 6 & 28 & 17 & 19 & 31.5 & 43.78 & 130.87 & 571 & 6.0 & \\
\hline 6536 & 2002 & 8 & 25 & 11 & 47 & 14.1 & 43.04 & 131.29 & 546 & 3.7 & \\
\hline 6548 & 2002 & 9 & 15 & 8 & 39 & 32.5 & 44.75 & 130.28 & 582 & 6.5 & \\
\hline 6566 & 2002 & 10 & 9 & 1 & 38 & 39.3 & 48.62 & 130.63 & 18 & 3.8 & 10.9 \\
\hline 6578 & 2002 & 10 & 21 & 15 & 21 & 36.1 & 51.37 & 132.79 & 12 & 3.8 & 10.8 \\
\hline 6601 & 2002 & 11 & 15 & 4 & 57 & 7.1 & 52.23 & 139.46 & 11 & 3.5 & 10.3 \\
\hline 6603 & 2002 & 11 & 15 & 14 & 0 & 35.0 & 42.99 & 130.85 & 561 & 3.6 & \\
\hline 6625 & 2002 & 12 & 8 & 20 & 54 & 15.8 & 51.05 & 124.68 & 20 & 4.5 & 12.5 \\
\hline 6626 & 2002 & 12 & 10 & 4 & 35 & 40.3 & 54.29 & 123.10 & 11 & 3.4 & 10.2 \\
\hline 6645 & 2002 & 12 & 31 & 16 & 22 & 38.3 & 48.27 & 132.22 & 19 & 3.9 & 10.8 \\
\hline 6651 & 2003 & 1 & 6 & 19 & 40 & 22.5 & 49.00 & 131.63 & 8 & 3.6 & 10.4 \\
\hline 6698 & 2003 & 2 & 7 & 9 & 51 & 43.0 & 43.39 & 134.19 & 425 & 3.7 & \\
\hline 6751 & 2003 & 3 & 5 & 19 & 11 & 50.0 & 43.38 & 135.26 & 360 & 4.4 & \\
\hline 6777 & 2003 & 3 & 20 & 2 & 50 & 25.4 & 49.34 & 139.30 & 10 & 3.3 & 10.0 \\
\hline 6861 & 2003 & 5 & 12 & 1 & 31 & 6.3 & 55.29 & 124.44 & 13 & 3.4 & 10.1 \\
\hline 6862 & 2003 & 5 & 14 & 3 & 34 & 17.0 & 43.22 & 136.09 & 338 & 5.3 & \\
\hline 6881 & 2003 & 6 & 1 & 2 & 49 & 20.4 & 49.64 & 130.65 & 7 & 3.8 & 11.3 \\
\hline 6884 & 2003 & 6 & 1 & 18 & 23 & 24.7 & 54.47 & 123.03 & 20 & 3.6 & 10.5 \\
\hline 6898 & 2003 & 6 & 14 & 14 & 10 & 9.7 & 49.11 & 131.83 & 7 & 3.6 & 10.5 \\
\hline 6942 & 2003 & 7 & 15 & 23 & 42 & 13.8 & 53.98 & 134.26 & 26 & 4.4 & 11.9 \\
\hline 6946 & 2003 & 7 & 18 & 14 & 3 & 9.0 & 54.03 & 134.28 & 16 & 4.4 & 12.3 \\
\hline 6963 & 2003 & 7 & 27 & 6 & 25 & 32.0 & 47.05 & 139.27 & 476 & 7.5 & \\
\hline 6971 & 2003 & 7 & 29 & 12 & 30 & 2.2 & 47.09 & 139.39 & 500 & 3.7 & \\
\hline 6973 & 2003 & 7 & 30 & 4 & 30 & 50.3 & 55.35 & 124.21 & 12 & 4.5 & 11.6 \\
\hline
\end{tabular}


Приложение 1А. Каталог землетрясений региона Приамурье и Приморье 1865-2015 гг. магнитудой М 23.3.

\begin{tabular}{|c|c|c|c|c|c|c|c|c|c|c|c|}
\hline № & & Іата & & & $t_{0}$ & & Эпи & ентр & $h$ & & \\
\hline$\Pi / \Pi$ & $\Gamma$ & $\mathrm{M}$ & д & $\mathrm{Y}$ & мин & $\mathrm{c}$ & $\varphi^{\circ}, \mathrm{N}$ & $\lambda^{\circ}, \mathrm{E}$ & км & $M / M L H$ & $K \mathrm{p}$ \\
\hline 6996 & 2003 & 8 & 18 & 18 & 34 & 30.5 & 42.60 & 134.36 & 445 & 3.5 & \\
\hline 7009 & 2003 & 8 & 31 & 23 & 8 & 0.9 & 43.42 & 132.56 & 490 & 7.1 & \\
\hline 7022 & 2003 & 9 & 19 & 2 & 25 & 39.2 & 55.05 & 122.41 & 14 & 3.3 & 10.0 \\
\hline 7025 & 2003 & 9 & 21 & 5 & 4 & 7.2 & 51.11 & 139.42 & 12 & 3.7 & 12.0 \\
\hline 7040 & 2003 & 10 & 7 & 15 & 27 & 23.5 & 44.99 & 133.69 & 30 & 4.4 & 12.1 \\
\hline 7046 & 2003 & 10 & 16 & 21 & 19 & 22.2 & 54.00 & 134.24 & 19 & 4.4 & 12.5 \\
\hline 7065 & 2003 & 11 & 11 & 7 & 51 & 25.5 & 52.58 & 132.55 & 15 & 3.3 & 10.0 \\
\hline 7079 & 2003 & 11 & 21 & 5 & 52 & 26.6 & 55.93 & 126.39 & 7 & 3.3 & 9.9 \\
\hline 7094 & 2003 & 12 & 7 & 5 & 34 & 14.9 & 51.59 & 134.66 & 16 & 3.5 & 10.3 \\
\hline 7141 & 2004 & 1 & 15 & 23 & 19 & 56.8 & 54.31 & 126.67 & 8 & 3.6 & 10.4 \\
\hline 7144 & 2004 & 1 & 16 & 19 & 8 & 33.0 & 53.08 & 129.91 & 11 & 5.0 & 13.5 \\
\hline 7160 & 2004 & 1 & 17 & 5 & 9 & 32.2 & 54.31 & 126.67 & 9 & 4.0 & 11.2 \\
\hline 7193 & 2004 & 1 & 25 & 19 & 46 & 29.2 & 53.12 & 128.87 & 9 & 4.1 & 11.4 \\
\hline 7263 & 2004 & 2 & 17 & 13 & 39 & 22.0 & 48.67 & 131.32 & 9 & 3.6 & 10.4 \\
\hline 7290 & 2004 & 2 & 26 & 8 & 58 & 30.0 & 42.09 & 134.27 & 425 & 3.5 & \\
\hline 7304 & 2004 & 3 & 5 & 6 & 16 & 42.3 & 55.90 & 124.38 & 12 & 3.3 & 9.9 \\
\hline 7319 & 2004 & 3 & 15 & 13 & 31 & 53.7 & 51.57 & 122.00 & 15 & 3.4 & 10.1 \\
\hline 7334 & 2004 & 3 & 24 & 19 & 55 & 50.2 & 54.36 & 125.59 & 9 & 4.5 & 12.4 \\
\hline 7360 & 2004 & 4 & 7 & 7 & 42 & 52.1 & 50.23 & 131.29 & 18 & 3.4 & 10.2 \\
\hline 7361 & 2004 & 4 & 7 & 20 & 1 & 19.6 & 49.93 & 129.22 & 9 & 3.4 & 10.1 \\
\hline 7434 & 2004 & 5 & 18 & 9 & 33 & 58.2 & 50.99 & 123.33 & 22 & 3.5 & 10.3 \\
\hline 7440 & 2004 & 5 & 20 & 14 & 43 & 14.3 & 43.16 & 136.58 & 326 & 5.7 & \\
\hline 7445 & 2004 & 5 & 25 & 11 & 9 & 12.0 & 55.95 & 125.51 & 14 & 4.2 & 11.6 \\
\hline 7475 & 2004 & 6 & 15 & 8 & 8 & 13.0 & 43.31 & 133.97 & 394 & 3.7 & \\
\hline 7496 & 2004 & 7 & 2 & 17 & 35 & 35.1 & 55.96 & 130.50 & 8 & 3.3 & 10.0 \\
\hline 7516 & 2004 & 7 & 19 & 16 & 39 & 9.9 & 45.22 & 137.35 & 328 & 3.3 & \\
\hline 7521 & 2004 & 7 & 26 & 16 & 15 & 50.0 & 42.98 & 133.95 & 454 & 3.6 & \\
\hline 7529 & 2004 & 8 & 2 & 16 & 24 & 16.8 & 53.78 & 136.39 & 24 & 3.5 & 11.2 \\
\hline 7536 & 2004 & 8 & 7 & 12 & 22 & 51.2 & 43.99 & 137.13 & 308 & 4.9 & \\
\hline 7551 & 2004 & 8 & 15 & 15 & 36 & 57.0 & 43.43 & 131.03 & 547 & 4.9 & \\
\hline 7565 & 2004 & 9 & 2 & 13 & 0 & 41.5 & 54.45 & 123.02 & 12 & 3.9 & 11.1 \\
\hline 7577 & 2004 & 9 & 15 & 2 & 37 & 28.0 & 47.16 & 139.30 & 473 & 4.3 & \\
\hline 7579 & 2004 & 9 & 16 & 17 & 14 & 36.9 & 45.18 & 131.75 & 12 & 3.8 & 10.9 \\
\hline 7638 & 2004 & 11 & 10 & 3 & 25 & 30.8 & 49.91 & 129.57 & 10 & 3.6 & 10.4 \\
\hline 7642 & 2004 & 11 & 11 & 19 & 56 & 56.7 & 54.13 & 135.29 & 18 & 3.7 & 10.7 \\
\hline 7672 & 2004 & 12 & 8 & 4 & 46 & 23.2 & 54.92 & 135.48 & 9 & 3.8 & 10.8 \\
\hline 7679 & 2004 & 12 & 14 & 4 & 57 & 43.4 & 56.23 & 124.23 & 14 & 3.7 & 10.7 \\
\hline 7710 & 2005 & 1 & 15 & 2 & 54 & 48.6 & 48.92 & 131.4 & 6 & 3.9 & 11.0 \\
\hline 7727 & 2005 & 1 & 24 & 12 & 22 & 47.2 & 51.97 & 122.65 & 23 & 4.6 & 13.0 \\
\hline 7734 & 2005 & 2 & 1 & 1 & 36 & 21.3 & 48.92 & 131.47 & 8 & 3.3 & 9.9 \\
\hline 7751 & 2005 & 2 & 7 & 3 & 1 & 58.4 & 54.39 & 131.89 & 8 & 3.3 & 10.9 \\
\hline 7753 & 2005 & 2 & 12 & 17 & 19 & 2 & 55.13 & 123.01 & 21 & 4.3 & 12.0 \\
\hline 7772 & 2005 & 3 & 5 & 8 & 57 & 36.4 & 49.82 & 132.26 & 11 & 3.9 & 11.0 \\
\hline
\end{tabular}


Приложение 1А. Каталог землетрясений региона Приамурье и Приморье 1865-2015 гг. магнитудой М $\geq 3.3$.

\begin{tabular}{|c|c|c|c|c|c|c|c|c|c|c|c|}
\hline \multirow{2}{*}{$\begin{array}{c}\text { № } \\
\Pi / \Pi\end{array}$} & \multicolumn{3}{|c|}{ Дата } & \multicolumn{3}{|c|}{$t_{0}$} & \multicolumn{2}{|c|}{ Эпицентр } & \multirow{2}{*}{$\begin{array}{c}h \\
\text { км }\end{array}$} & \multirow[b]{2}{*}{$M / M L H$} & \multirow[b]{2}{*}{$K \mathrm{p}$} \\
\hline & $\Gamma$ & $\mathrm{M}$ & д & ч & мин & $\mathrm{c}$ & $\varphi^{\circ}, \mathrm{N}$ & $\lambda^{\circ}, \mathrm{E}$ & & & \\
\hline 7776 & 2005 & 3 & 10 & 9 & 1 & 41.6 & 54.54 & 133.96 & 10 & 3.6 & 10.4 \\
\hline 7800 & 2005 & 3 & 23 & 2 & 13 & 1.4 & 48.46 & 132.63 & 17 & 4.5 & 12.0 \\
\hline 7824 & 2005 & 4 & 6 & 13 & 45 & 39 & 46.16 & 136.81 & 381 & 4.1 & \\
\hline 7831 & 2005 & 4 & 14 & 9 & 56 & 7.3 & 43.42 & 135.4 & 351 & 4.9 & \\
\hline 7890 & 2005 & 5 & 24 & 10 & 46 & 48.6 & 52.27 & 133.15 & 12 & 3.6 & 10.5 \\
\hline 7898 & 2005 & 6 & 3 & 15 & 1 & 20 & 49.95 & 135.54 & 10 & 3.6 & 10.4 \\
\hline 7921 & 2005 & 7 & 6 & 19 & 42 & 38.6 & 48.33 & 131.73 & 21 & 3.9 & 11.0 \\
\hline 7922 & 2005 & 7 & 6 & 23 & 10 & 15.7 & 48.37 & 131.65 & 22 & 4.4 & 12.0 \\
\hline 7957 & 2005 & 8 & 13 & 5 & 48 & 28.1 & 52.34 & 133.54 & 18 & 4.4 & 12.0 \\
\hline 7959 & 2005 & 8 & 14 & 9 & 59 & 36.3 & 51.58 & 122.88 & 14 & 3.3 & 10.0 \\
\hline 7963 & 2005 & 8 & 15 & 19 & 31 & 47.6 & 48.93 & 131.29 & 12 & 3.7 & 10.6 \\
\hline 7998 & 2005 & 9 & 20 & 23 & 1 & 51.3 & 54.20 & 125.64 & 9 & 3.5 & 10.3 \\
\hline 8014 & 2005 & 9 & 30 & 6 & 20 & 20.7 & 52.96 & 134.36 & 11 & 4.3 & 11.0 \\
\hline 8017 & 2005 & 10 & 1 & 16 & 57 & 17 & 43.10 & 134.71 & 384 & 4.0 & \\
\hline 8028 & 2005 & 10 & 14 & 6 & 3 & 7 & 42.55 & 133.17 & 507 & 3.8 & \\
\hline 8042 & 2005 & 10 & 29 & 15 & 48 & 27.4 & 54.05 & 122.07 & 13 & 3.3 & 9.9 \\
\hline 8057 & 2005 & 11 & 20 & 14 & 44 & 28.6 & 52.46 & 131.48 & 10 & 3.6 & 10.5 \\
\hline 8063 & 2005 & 11 & 25 & 17 & 44 & 50.1 & 45.41 & 137.04 & 330 & 3.7 & \\
\hline 8082 & 2005 & 12 & 8 & 15 & 39 & 20.7 & 45.00 & 137.38 & 320 & 3.9 & \\
\hline 8083 & 2005 & 12 & 8 & 23 & 20 & 49.7 & 50.00 & 136.83 & 10 & 3.3 & 9.9 \\
\hline 8118 & 2006 & 1 & 5 & 2 & 58 & 16.2 & 48.95 & 131.38 & 15 & 3.5 & 10.3 \\
\hline 8125 & 2006 & 1 & 11 & 23 & 21 & 49.9 & 53.96 & 127.98 & 13 & 3.8 & 10.9 \\
\hline 8167 & 2006 & 2 & 15 & 23 & 1 & 3.3 & 43.35 & 134.82 & 341 & 3.7 & \\
\hline 8182 & 2006 & 3 & 3 & 15 & 39 & 36.4 & 44.81 & 135.41 & 347 & 3.9 & \\
\hline 8210 & 2006 & 3 & 24 & 10 & 55 & 0.2 & 47.33 & 138.83 & 461 & 3.5 & \\
\hline 8285 & 2006 & 6 & 7 & 2 & 43 & 56.3 & 51.02 & 135.19 & 12 & 3.3 & 9.9 \\
\hline 8315 & 2006 & 7 & 12 & 11 & 25 & 2.5 & 52.64 & 138.96 & 10 & 3.3 & 9.9 \\
\hline 8319 & 2006 & 7 & 26 & 20 & 51 & 5.3 & 43.76 & 130.59 & 576 & 3.7 & \\
\hline 8337 & 2006 & 8 & 19 & 13 & 14 & 50.8 & 48.97 & 131.65 & 10 & 3.4 & 10.1 \\
\hline 8367 & 2006 & 9 & 12 & 6 & 39 & 32.7 & 42.80 & 134.51 & 418 & 4.0 & \\
\hline 8381 & 2006 & 9 & 28 & 2 & 17 & 25.6 & 53.38 & 123.06 & 22 & 3.5 & 10.3 \\
\hline 8393 & 2006 & 10 & 9 & 19 & 46 & 14.2 & 45.40 & 137.16 & 335 & 4.5 & \\
\hline 8401 & 2006 & 10 & 17 & 12 & 56 & 49.3 & 55.83 & 124.84 & 9 & 4.2 & 11.9 \\
\hline 8453 & 2006 & 11 & 30 & 18 & 4 & 12.5 & 55.83 & 124.48 & 8 & 3.4 & 10.1 \\
\hline 8483 & 2006 & 12 & 24 & 16 & 24 & 16.1 & 54.25 & 127.39 & 7 & 3.3 & 9.9 \\
\hline 8505 & 2007 & 1 & 12 & 23 & 28 & 50.9 & 51.14 & 136.91 & 20 & 4.7 & 13.5 \\
\hline 8511 & 2007 & 1 & 17 & 15 & 45 & 32.8 & 54.30 & 128.58 & 7 & 3.7 & 10.7 \\
\hline 8569 & 2007 & 3 & 9 & 3 & 22 & 42.6 & 43.28 & 133.63 & 445 & 6.5 & \\
\hline 8577 & 2007 & 3 & 13 & 15 & 19 & 9.3 & 54.23 & 132.09 & 9 & 3.6 & 10.4 \\
\hline 8607 & 2007 & 3 & 22 & 12 & 28 & 20.3 & 45.36 & 131.19 & 25 & 4.1 & 11.6 \\
\hline 8678 & 2007 & 4 & 22 & 10 & 3 & 57.9 & 48.60 & 133.52 & 14 & 4.1 & 12.2 \\
\hline 8690 & 2007 & 4 & 29 & 13 & 40 & 15.4 & 45.02 & 137.45 & 323 & 4.4 & \\
\hline 8698 & 2007 & 5 & 3 & 20 & 2 & 3.5 & 52.56 & 139.48 & 10 & 4.3 & 11.7 \\
\hline
\end{tabular}


Приложение 1А. Каталог землетрясений региона Приамурье и Приморье 1865-2015 гг. магнитудой М $\geq 3.3$.

\begin{tabular}{|c|c|c|c|c|c|c|c|c|c|c|c|}
\hline № & & Іата & & & $t_{0}$ & & ЭПи & нтр & $h$ & & \\
\hline$\Pi / \Pi$ & $\Gamma$ & $\mathrm{M}$ & д & 4 & мин & $\mathrm{c}$ & $\varphi^{\circ}, \mathrm{N}$ & $\lambda^{\circ}, \mathrm{E}$ & км & $M / M L H$ & $K \mathrm{p}$ \\
\hline 8720 & 2007 & 5 & 20 & 13 & 23 & 51.1 & 52.63 & 139.55 & 19 & 4.8 & 13.0 \\
\hline 8722 & 2007 & 5 & 21 & 21 & 56 & 55.4 & 44.41 & 137.08 & 312 & 4.0 & \\
\hline 8733 & 2007 & 6 & 19 & 21 & 13 & 54.1 & 43.53 & 133.84 & 421 & 4.0 & \\
\hline 8738 & 2007 & 6 & 26 & 23 & 11 & 47.9 & 43.58 & 134.31 & 436 & 4.1 & \\
\hline 8771 & 2007 & 8 & 4 & 17 & 54 & 33 & 52.74 & 134.46 & 19 & 4.1 & 11.4 \\
\hline 8797 & 2007 & 8 & 28 & 15 & 26 & 34.3 & 52.52 & 139.69 & 21 & 3.8 & 10.9 \\
\hline 8812 & 2007 & 9 & 15 & 20 & 56 & 16.4 & 53.41 & 132.39 & 12 & 4.1 & 12.2 \\
\hline 8832 & 2007 & 10 & 5 & 14 & 24 & 45.9 & 44.07 & 130.85 & 563 & 4.0 & \\
\hline 8851 & 2007 & 10 & 27 & 23 & 49 & 55.5 & 42.23 & 133.91 & 450 & 4.1 & \\
\hline 8904 & 2007 & 12 & 4 & 0 & 14 & 11.3 & 42.11 & 133.97 & 437 & 4.5 & \\
\hline 8941 & 2007 & 12 & 25 & 20 & 57 & 4.7 & 54.61 & 122.92 & 26 & 3.4 & 10.1 \\
\hline 8990 & 2008 & 1 & 26 & 6 & 46 & 34.3 & 54.00 & 126.42 & 22 & 3.3 & 10.0 \\
\hline 9009 & 2008 & 2 & 6 & 16 & 47 & 35.2 & 45.02 & 138.38 & 301 & 3.6 & \\
\hline 9035 & 2008 & 2 & 22 & 9 & 20 & 1.0 & 48.53 & 131.59 & 19 & 4.4 & 11.9 \\
\hline 9041 & 2008 & 2 & 24 & 9 & 25 & 35.6 & 55.28 & 122.72 & 24 & 3.4 & 10.2 \\
\hline 9050 & 2008 & 2 & 27 & 15 & 18 & 56.4 & 54.82 & 125.37 & 14 & 3.5 & 10.3 \\
\hline 9078 & 2008 & 3 & 16 & 19 & 20 & 39.5 & 43.46 & 133.63 & 455 & 3.9 & \\
\hline 9103 & 2008 & 4 & 3 & 7 & 33 & 39.2 & 46.99 & 131.31 & 19 & 3.8 & 10.8 \\
\hline 9113 & 2008 & 4 & 9 & 23 & 12 & 50.7 & 43.12 & 133.73 & 435 & 4.4 & \\
\hline 9180 & 2008 & 5 & 19 & 10 & 8 & 35.7 & 42.55 & 132.09 & 518 & 6.3 & \\
\hline 9221 & 2008 & 6 & 17 & 17 & 26 & 11.9 & 54.00 & 127.99 & 16 & 5.4 & 13.6 \\
\hline 9243 & 2008 & 6 & 29 & 20 & 53 & 2.4 & 45.00 & 137.51 & 319 & 5.2 & \\
\hline 9308 & 2008 & 8 & 26 & 8 & 25 & 29.1 & 51.85 & 132.87 & 9 & 3.9 & 11.1 \\
\hline 9309 & 2008 & 8 & 27 & 18 & 29 & 20.9 & 55.20 & 124.06 & 8 & 3.8 & 11.4 \\
\hline 9315 & 2008 & 8 & 31 & 10 & 40 & 17.6 & 54.01 & 127.98 & 19 & 3.3 & 10.0 \\
\hline 9385 & 2008 & 10 & 22 & 16 & 18 & 36.0 & 41.98 & 131.45 & 558 & 4.9 & \\
\hline 9393 & 2008 & 10 & 25 & 17 & 43 & 32.5 & 55.28 & 135.17 & 7 & 3.8 & 10.9 \\
\hline 9394 & 2008 & 10 & 26 & 1 & 23 & 50.8 & 50.49 & 135.98 & 10 & 3.4 & 10.2 \\
\hline 9400 & 2008 & 10 & 29 & 0 & 6 & 42.9 & 55.25 & 123.95 & 7 & 3.5 & 10.3 \\
\hline 9417 & 2008 & 11 & 6 & 9 & 53 & 1.5 & 55.54 & 128.82 & 10 & 3.5 & 10.9 \\
\hline 9427 & 2008 & 11 & 13 & 8 & 22 & 52.0 & 54.31 & 122.42 & 20 & 3.4 & 10.1 \\
\hline 9462 & 2008 & 12 & 17 & 15 & 53 & 24.5 & 42.64 & 131.92 & 512 & 3.6 & \\
\hline 9482 & 2008 & 12 & 28 & 21 & 28 & 50.2 & 47.48 & 130.33 & 10 & 3.4 & 10.1 \\
\hline 9529 & 2009 & 1 & 31 & 18 & 17 & 59.8 & 54.21 & 125.97 & 8 & 3.3 & 9.9 \\
\hline 9536 & 2009 & 2 & 3 & 13 & 39 & 34.3 & 52.66 & 136.19 & 22 & 3.3 & 9.9 \\
\hline 9582 & 2009 & 3 & 6 & 3 & 32 & 36.7 & 42.79 & 131.83 & 522 & 4.1 & \\
\hline 9597 & 2009 & 3 & 13 & 9 & 7 & 1.9 & 43.27 & 134.32 & 422 & 5.1 & \\
\hline 9645 & 2009 & 4 & 4 & 1 & 59 & 19.1 & 48.97 & 131.38 & 10 & 3.7 & 10.7 \\
\hline 9649 & 2009 & 4 & 5 & 0 & 30 & 18.4 & 48.93 & 131.57 & 16 & 3.8 & 10.9 \\
\hline 9652 & 2009 & 4 & 6 & 5 & 9 & 33.3 & 42.88 & 131.75 & 526 & 4.5 & \\
\hline 9666 & 2009 & 4 & 13 & 15 & 10 & 28.4 & 53.08 & 134.23 & 12 & 4.4 & 12.1 \\
\hline 9675 & 2009 & 4 & 15 & 8 & 17 & 18.8 & 53.82 & 130.25 & 11 & 3.9 & 11.1 \\
\hline 9685 & 2009 & 4 & 18 & 3 & 56 & 29.9 & 42.82 & 130.62 & 564 & 4.9 & \\
\hline
\end{tabular}


Приложение 1А. Каталог землетрясений региона Приамурье и Приморье 1865-2015 гг. магнитудой М $\geq 3.3$.

\begin{tabular}{|c|c|c|c|c|c|c|c|c|c|c|c|}
\hline № & & ата & & & $t_{0}$ & & Эпи & нтр & $h$ & & \\
\hline$\Pi / \Pi$ & $\Gamma$ & $\mathrm{M}$ & д & ч & мин & $\mathrm{c}$ & $\varphi^{\circ}, \mathrm{N}$ & $\lambda^{\circ}, \mathrm{E}$ & км & $M / M L H$ & $K p$ \\
\hline 9695 & 2009 & 4 & 21 & 6 & 15 & 3.0 & 51.19 & 136.91 & 29 & 4.0 & 11.1 \\
\hline 9701 & 2009 & 4 & 26 & 10 & 48 & 49.5 & 55.99 & 129.43 & 20 & 3.9 & 11.0 \\
\hline 9740 & 2009 & 5 & 24 & 0 & 30 & 46.2 & 54.51 & 129.20 & 10 & 3.9 & 11.0 \\
\hline 9743 & 2009 & 5 & 26 & 12 & 4 & 7.5 & 43.72 & 135.74 & 341 & 3.9 & \\
\hline 9747 & 2009 & 5 & 28 & 2 & 21 & 43.4 & 55.08 & 122.69 & 24 & 3.7 & 10.6 \\
\hline 9771 & 2009 & 6 & 7 & 16 & 26 & 5.5 & 43.78 & 130.77 & 566 & 4.1 & \\
\hline 9781 & 2009 & 6 & 14 & 9 & 22 & 32.2 & 48.42 & 130.10 & 10 & 4.1 & 11.4 \\
\hline 9799 & 2009 & 6 & 19 & 15 & 24 & 1.6 & 50.30 & 135.87 & 21 & 3.9 & 11.1 \\
\hline 9821 & 2009 & 7 & 6 & 8 & 52 & 39.2 & 47.96 & 130.70 & 10 & 3.4 & 10.1 \\
\hline 9833 & 2009 & 7 & 12 & 23 & 31 & 28.4 & 43.38 & 130.53 & 572 & 4.3 & \\
\hline 9840 & 2009 & 7 & 16 & 6 & 29 & 3.8 & 42.42 & 133.23 & 475 & 4.9 & \\
\hline 9854 & 2009 & 7 & 23 & 16 & 25 & 44.1 & 56.23 & 131.88 & 12 & 3.4 & 10.1 \\
\hline 9875 & 2009 & 8 & 10 & 12 & 42 & 52.7 & 43.51 & 130.80 & 567 & 4.9 & \\
\hline 9885 & 2009 & 8 & 21 & 11 & 38 & 1.1 & 42.20 & 133.68 & 456 & 3.6 & \\
\hline 9919 & 2009 & 9 & 26 & 20 & 33 & 21.5 & 55.78 & 134.41 & 7 & 3.4 & 10.0 \\
\hline 9931 & 2009 & 10 & 2 & 14 & 57 & 18.4 & 55.86 & 134.49 & 10 & 3.4 & 10.1 \\
\hline 9933 & 2009 & 10 & 2 & 16 & 51 & 44.3 & 55.88 & 134.42 & 10 & 3.3 & 9.9 \\
\hline 9935 & 2009 & 10 & 3 & 4 & 16 & 42.1 & 51.58 & 136.28 & 10 & 3.3 & 9.9 \\
\hline 9948 & 2009 & 10 & 16 & 1 & 19 & 11.4 & 55.12 & 122.38 & 13 & 3.3 & 10.0 \\
\hline 9990 & 2009 & 11 & 15 & 20 & 31 & 34.6 & 44.40 & 137.08 & 306 & 5.1 & \\
\hline 9997 & 2009 & 11 & 20 & 22 & 47 & 18.5 & 45.55 & 131.95 & 10 & 3.4 & 10.1 \\
\hline 10029 & 2009 & 12 & 17 & 7 & 56 & 8.2 & 54.42 & 129.08 & 7 & 3.3 & 9.9 \\
\hline 10032 & 2009 & 12 & 19 & 13 & 26 & 4.9 & 45.22 & 131.25 & 13 & 4.4 & 12.0 \\
\hline 10043 & 2009 & 12 & 24 & 0 & 23 & 29.0 & 42.04 & 135.17 & 382 & 6.5 & \\
\hline 10098 & 2010 & 1 & 30 & 23 & 55 & 27.2 & 50.28 & 126.13 & 24 & 3.6 & 10.4 \\
\hline 10115 & 2010 & 2 & 18 & 1 & 13 & 17.8 & 42.65 & 130.74 & 578 & 7.3 & \\
\hline 10120 & 2010 & 2 & 21 & 7 & 29 & 8.8 & 42.59 & 130.80 & 578 & 4.0 & \\
\hline 10128 & 2010 & 2 & 25 & 23 & 6 & 32.7 & 55.37 & 130.59 & 8 & 3.3 & 10.0 \\
\hline 10138 & 2010 & 3 & 10 & 10 & 54 & 56.1 & 46.61 & 131.58 & 15 & 4.3 & 12.0 \\
\hline 10173 & 2010 & 3 & 30 & 12 & 4 & 29.2 & 49.13 & 131.84 & 9 & 3.9 & 11.0 \\
\hline 10177 & 2010 & 3 & 31 & 7 & 15 & 47.5 & 54.96 & 135.14 & 15 & 3.7 & 10.6 \\
\hline 10351 & 2010 & 6 & 21 & 17 & 22 & 16.4 & 54.24 & 125.87 & 8 & 3.6 & 10.5 \\
\hline 10364 & 2010 & 7 & 1 & 15 & 52 & 30.2 & 53.11 & 133.01 & 10 & 3.7 & 10.7 \\
\hline 10370 & 2010 & 7 & 3 & 12 & 46 & 42.4 & 47.13 & 135.55 & 11 & 3.3 & 10.0 \\
\hline 10398 & 2010 & 7 & 18 & 4 & 10 & 59.0 & 46.10 & 132.91 & 22 & 3.6 & 10.5 \\
\hline 10422 & 2010 & 8 & 7 & 13 & 47 & 39.9 & 49.79 & 132.48 & 8 & 3.4 & 10.1 \\
\hline 10436 & 2010 & 8 & 14 & 11 & 19 & 6.4 & 53.84 & 138.81 & 12 & 3.6 & 10.5 \\
\hline 10467 & 2010 & 9 & 9 & 1 & 12 & 49.0 & 42.63 & 130.86 & 572 & 3.7 & \\
\hline 10478 & 2010 & 9 & 15 & 9 & 50 & 52.8 & 47.17 & 130.15 & 10 & 3.3 & 9.9 \\
\hline 10487 & 2010 & 9 & 23 & 22 & 9 & 17.6 & 52.39 & 139.73 & 14 & 4.4 & 12.7 \\
\hline 10509 & 2010 & 10 & 7 & 0 & 6 & 14.6 & 53.28 & 124.35 & 10 & 3.6 & 10.5 \\
\hline 10546 & 2010 & 11 & 1 & 9 & 49 & 50.9 & 45.08 & 137.37 & 324 & 3.9 & \\
\hline 10578 & 2010 & 12 & 5 & 2 & 42 & 44.1 & 51.18 & 136.09 & 6 & 3.6 & 10.4 \\
\hline
\end{tabular}


Приложение 1А. Каталог землетрясений региона Приамурье и Приморье 1865-2015 гг. магнитудой М 23.3.

\begin{tabular}{|c|c|c|c|c|c|c|c|c|c|c|c|}
\hline № & & Қата & & & $t_{0}$ & & Эпи & нтр & $h$ & & \\
\hline п/п & $\Gamma$ & $\mathrm{M}$ & д & ч & мин & $\mathrm{c}$ & $\varphi^{\circ}, \mathrm{N}$ & $\lambda^{\circ}, \mathrm{E}$ & км & $M / M L H$ & $K p$ \\
\hline 10588 & 2010 & 12 & 13 & 0 & 52 & 38.9 & 54.29 & 127.15 & 12 & 3.4 & 10.1 \\
\hline 10599 & 2010 & 12 & 21 & 6 & 49 & 49.1 & 50.59 & 132.08 & 9 & 3.8 & 10.9 \\
\hline 10602 & 2010 & 12 & 23 & 1 & 4 & 38.4 & 55.50 & 123.91 & 10 & 4.3 & 11.7 \\
\hline 10630 & 2011 & 1 & 7 & 23 & 34 & 10.9 & 43.09 & 131.19 & 555 & 4.5 & \\
\hline 10644 & 2011 & 1 & 15 & 0 & 43 & 42.7 & 48.67 & 125.92 & 15 & 4.5 & 12.7 \\
\hline 10676 & 2011 & 2 & 5 & 12 & 42 & 14.5 & 50.72 & 134.99 & 14 & 4.0 & 11.7 \\
\hline 10712 & 2011 & 2 & 25 & 17 & 0 & 16.5 & 43.70 & 134.21 & 420 & 3.6 & \\
\hline 10757 & 2011 & 4 & 3 & 7 & 43 & 21.6 & 48.95 & 131.43 & 9 & 3.9 & 11.0 \\
\hline 10772 & 2011 & 4 & 8 & 17 & 12 & 16.4 & 54.06 & 122.79 & 8 & 3.6 & 10.4 \\
\hline 10781 & 2011 & 4 & 11 & 16 & 51 & 24 & 48.89 & 131.34 & 8 & 3.5 & 10.3 \\
\hline 10792 & 2011 & 4 & 21 & 3 & 8 & 29 & 48.83 & 131.78 & 21 & 3.4 & 10.2 \\
\hline 10800 & 2011 & 4 & 26 & 4 & 0 & 6.1 & 48.21 & 130.77 & 15 & 3.6 & 10.4 \\
\hline 10820 & 2011 & 5 & 10 & 15 & 26 & 4.3 & 43.31 & 131.17 & 554 & 5.7 & \\
\hline 10860 & 2011 & 6 & 23 & 17 & 13 & 14.8 & 54.14 & 126.28 & 17 & 3.6 & 10.5 \\
\hline 10864 & 2011 & 6 & 26 & 15 & 34 & 20 & 52.19 & 132.63 & 15 & 3.7 & 10.7 \\
\hline 10872 & 2011 & 7 & 6 & 14 & 3 & 16.8 & 55.67 & 130.77 & 18 & 3.4 & 10.2 \\
\hline 10897 & 2011 & 7 & 25 & 0 & 21 & 52 & 50.07 & 135.69 & 8 & 3.6 & 10.4 \\
\hline 10905 & 2011 & 8 & 4 & 23 & 34 & 38.4 & 54.10 & 133.37 & 10 & 3.7 & 10.8 \\
\hline 10945 & 2011 & 9 & 22 & 15 & 1 & 23 & 44.70 & 131.08 & 10 & 3.3 & 9.9 \\
\hline 10955 & 2011 & 10 & 14 & 6 & 10 & 13.8 & 54.10 & 123.81 & 18 & 6.2 & 15.4 \\
\hline 10956 & 2011 & 10 & 14 & 6 & 23 & 58.5 & 54.05 & 123.86 & 10 & 4.0 & 11.2 \\
\hline 10957 & 2011 & 10 & 14 & 6 & 26 & 34.6 & 54.10 & 123.93 & 10 & 3.4 & 10.1 \\
\hline 10960 & 2011 & 10 & 14 & 7 & 19 & 52.9 & 54.18 & 123.88 & 10 & 3.4 & 10.1 \\
\hline 10961 & 2011 & 10 & 14 & 7 & 37 & 9.3 & 54.12 & 123.81 & 10 & 3.7 & 10.6 \\
\hline 10991 & 2011 & 10 & 18 & 13 & 59 & 20.4 & 54.20 & 123.99 & 20 & 4.2 & 11.5 \\
\hline 11007 & 2011 & 10 & 22 & 14 & 14 & 57 & 54.19 & 123.82 & 14 & 4.0 & 11.2 \\
\hline 11016 & 2011 & 10 & 27 & 17 & 44 & 1.5 & 54.17 & 123.95 & 18 & 3.3 & 10.0 \\
\hline 11018 & 2011 & 10 & 29 & 20 & 14 & 35 & 54.10 & 123.93 & 15 & 3.8 & 10.8 \\
\hline 11025 & 2011 & 11 & 4 & 15 & 54 & 30.6 & 54.21 & 123.83 & 15 & 3.4 & 10.2 \\
\hline 11027 & 2011 & 11 & 8 & 15 & 27 & 7.3 & 55.01 & 122.32 & 13 & 3.4 & 10.1 \\
\hline 11039 & 2011 & 11 & 14 & 11 & 37 & 28.1 & 53.97 & 128.09 & 20 & 3.4 & 10.1 \\
\hline 11042 & 2011 & 11 & 15 & 22 & 43 & 52.1 & 53.34 & 132.63 & 11 & 3.4 & 10.2 \\
\hline 11046 & 2011 & 11 & 18 & 23 & 10 & 24.4 & 54.46 & 123.18 & 10 & 3.4 & 10.2 \\
\hline 11051 & 2011 & 11 & 22 & 1 & 52 & 14.6 & 54.13 & 123.92 & 16 & 3.6 & 10.5 \\
\hline 11064 & 2011 & 12 & 4 & 7 & 11 & 16.6 & 54.25 & 123.92 & 10 & 4.3 & 11.8 \\
\hline 11108 & 2012 & 1 & 22 & 23 & 42 & 50.57 & 54.41 & 122.78 & 14 & 3.5 & 10.4 \\
\hline 11167 & 2012 & 4 & 10 & 20 & 7 & 4.156 & 52.66 & 132.4 & 14 & 3.3 & 9.9 \\
\hline 11215 & 2012 & 6 & 18 & 5 & 11 & 31.61 & 47.95 & 130.97 & 18 & 4.9 & 13.7 \\
\hline 11222 & 2012 & 6 & 28 & 12 & 28 & 38.97 & 52.80 & 135.73 & 17 & 3.5 & 10.3 \\
\hline 11237 & 2012 & 7 & 29 & 9 & 20 & 52.95 & 47.26 & 139.3 & 504 & 6.4 & \\
\hline 11280 & 2012 & 9 & 22 & 10 & 56 & 7.956 & 54.19 & 123.93 & 18 & 3.7 & 11.2 \\
\hline 11311 & 2012 & 11 & 1 & 4 & 57 & 31.48 & 54.15 & 126.57 & 22 & 3.8 & 10.8 \\
\hline 11351 & 2013 & 1 & 2 & 19 & 45 & 11.54 & 54.32 & 122.97 & 15 & 4.1 & 11.4 \\
\hline
\end{tabular}


Приложение 1А. Каталог землетрясений региона Приамурье и Приморье 1865-2015 гг. магнитудой М $\geq 3.3$.

\begin{tabular}{|c|c|c|c|c|c|c|c|c|c|c|c|}
\hline № & \multicolumn{3}{|c|}{ Дата } & \multicolumn{3}{|c|}{$t_{0}$} & \multicolumn{2}{|c|}{ Эпицентр } & \multirow{2}{*}{$\begin{array}{c}h \\
\text { км }\end{array}$} & \multirow[b]{2}{*}{$M / M L H$} & \multirow[b]{2}{*}{$K p$} \\
\hline$\Pi / \Pi$ & $\Gamma$ & $\mathrm{M}$ & д & ч & мин & $\mathrm{c}$ & $\varphi^{\circ}, \mathrm{N}$ & $\lambda^{\circ}, \mathrm{E}$ & & & \\
\hline 11394 & 2013 & 2 & 20 & 11 & 30 & 29.38 & 51.04 & 124.92 & 15 & 4.1 & 11.0 \\
\hline 11442 & 2013 & 4 & 5 & 13 & 0 & 1.815 & 42.76 & 131.29 & 570 & 6.5 & \\
\hline 11443 & 2013 & 4 & 6 & 0 & 29 & 54.9 & 42.80 & 131.22 & 568 & 5.9 & \\
\hline 11458 & 2013 & 4 & 13 & 5 & 18 & 28.47 & 54.22 & 126.95 & 7 & 3.7 & $\overline{10.6}$ \\
\hline 11483 & 2013 & 5 & 8 & 8 & 13 & 52.71 & 45.31 & 137.09 & 337 & 3.4 & \\
\hline 11511 & 2013 & 6 & 14 & 23 & 39 & 25.99 & 54.15 & 123.93 & 14 & 3.9 & 11.0 \\
\hline 11526 & 2013 & 6 & 30 & 2 & 48 & 27.6 & 56.00 & 131.89 & 10 & 3.5 & 10.3 \\
\hline 11549 & 2013 & 7 & 22 & 15 & 8 & 49.82 & 51.47 & 132.01 & 13 & 4.6 & 13.6 \\
\hline 11552 & 2013 & 7 & 23 & 9 & 18 & 7.665 & 42.06 & 133.23 & 481 & 4.1 & \\
\hline 11560 & 2013 & 8 & 1 & 18 & 39 & 30.65 & 45.94 & 138.58 & 20 & 3.9 & 11.0 \\
\hline 11570 & 2013 & 8 & 15 & 0 & 15 & 9.327 & 55.51 & 133.67 & 9 & 3.3 & 9.9 \\
\hline 11577 & 2013 & 9 & 2 & 2 & 51 & 12.54 & 42.15 & 133.83 & 449 & 6.0 & \\
\hline 11579 & 2013 & 9 & 6 & 2 & 56 & 24.8 & 53.93 & 128.15 & 26 & 3.4 & 10.1 \\
\hline 11583 & 2013 & 9 & 11 & 0 & 46 & 14.8 & 55.09 & 122.38 & 6 & 3.5 & 10.3 \\
\hline 11591 & 2013 & 9 & 27 & 18 & 36 & 40.99 & 43.41 & 134.28 & 435 & 4.7 & \\
\hline 11618 & 2013 & 10 & 29 & 20 & 17 & 49.13 & 43.20 & 131.14 & 550 & 5.7 & \\
\hline 11634 & 2013 & 11 & 12 & 4 & 16 & 43.34 & 52.32 & 131.33 & 8 & 3.6 & 10.4 \\
\hline 11641 & 2013 & 11 & 19 & 18 & 57 & 28.93 & 46.00 & 130.65 & 16 & 4.8 & 12.8 \\
\hline 11660 & 2013 & 12 & 15 & 18 & 46 & 7.902 & 55.72 & 137.06 & 27 & 3.3 & 10.0 \\
\hline 11676 & 2014 & 1 & 3 & 22 & 57 & 9.892 & 54.03 & 122.08 & 8 & 3.8 & 10.9 \\
\hline 11727 & 2014 & 2 & 20 & 1 & 32 & 51.1 & 42.83 & 132.26 & 520 & 4.5 & \\
\hline 11747 & 2014 & 3 & 5 & 3 & 0 & 20.93 & 51.11 & 131.84 & 10 & 3.6 & 10.6 \\
\hline 11767 & 2014 & 3 & 22 & 7 & 1 & 43.5 & 46.96 & 129.99 & 8 & 3.4 & 10.2 \\
\hline 11775 & 2014 & 3 & 31 & 21 & 23 & 1.698 & 49.19 & 126.49 & 10 & 3.3 & 9.9 \\
\hline 11786 & 2014 & 4 & 12 & 21 & 22 & 44.25 & 44.90 & 133.66 & 14 & 4.4 & 11.9 \\
\hline 11795 & 2014 & 4 & 24 & 11 & 31 & 1.551 & 48.07 & 139.69 & 10 & 3.4 & 10.1 \\
\hline 11833 & 2014 & 6 & 1 & 2 & 55 & 26.12 & 54.16 & 123.95 & 18 & 4.0 & 11.2 \\
\hline 11860 & 2014 & 6 & 23 & 9 & 53 & 0.262 & 53.69 & 138.91 & 8 & 3.6 & 10.4 \\
\hline 11898 & 2014 & 7 & 27 & 13 & 11 & 26.36 & 52.76 & 135.71 & 12 & 3.6 & 10.5 \\
\hline 11920 & 2014 & 8 & 15 & 1 & 6 & 20.66 & 54.48 & 135.2 & 12 & 3.4 & 10.1 \\
\hline 11936 & 2014 & 8 & 31 & 8 & 29 & 2.423 & 54.90 & 122.41 & 24 & 3.6 & 10.4 \\
\hline 11947 & 2014 & 9 & 11 & 15 & 59 & 24.04 & 51.75 & 132.97 & 10 & 3.3 & 10.0 \\
\hline 12022 & 2014 & 11 & 20 & 19 & 46 & 23.29 & 52.07 & 133.89 & 11 & 3.6 & 10.5 \\
\hline 12026 & 2014 & 11 & 24 & 9 & 31 & 19.24 & 45.41 & 131.96 & 9 & 3.4 & 10.1 \\
\hline 12031 & 2014 & 11 & 30 & 1 & 33 & 29.39 & 54.18 & 122.09 & 16 & 3.5 & 10.3 \\
\hline 12046 & 2014 & 12 & 15 & 14 & 59 & 7.68 & 52.30 & 137.26 & 17 & 3.7 & 10.6 \\
\hline 12056 & 2014 & 12 & 25 & 7 & 50 & 20.6 & 44.79 & 138.54 & 277 & 3.5 & \\
\hline 12062 & 2015 & 1 & 3 & 13 & 47 & 29.11 & 53.84 & 125.53 & 13 & 3.3 & 9.9 \\
\hline 12065 & 2015 & 1 & 3 & 20 & 19 & 59.27 & 47.31 & 136.85 & 18 & 3.3 & 10.0 \\
\hline 12066 & 2015 & 1 & 3 & 23 & 51 & 2.542 & 47.32 & 136.87 & 8 & 3.8 & 10.9 \\
\hline 12067 & 2015 & 1 & 7 & 0 & 19 & 4.713 & 53.69 & 125.45 & 8 & 3.4 & 10.1 \\
\hline 12107 & 2015 & 2 & 7 & 16 & 40 & 5.911 & 43.53 & 135.82 & 354 & 4.6 & \\
\hline 12155 & 2015 & 4 & 6 & 22 & 14 & 5.3 & 55.98 & 128.65 & 13 & 3.8 & 10.9 \\
\hline
\end{tabular}


Приложение 1А. Каталог землетрясений региона Приамурье и Приморье 1865-2015 гг. магнитудой М $\geq 3.3$.

\begin{tabular}{|c|c|c|c|c|c|c|c|c|c|c|c|}
\hline № & \multicolumn{3}{|c|}{ Дата } & \multicolumn{3}{c|}{$t_{0}$} & \multicolumn{2}{|c|}{ Эпицентр } & \multicolumn{2}{c|}{$h$} & \multicolumn{2}{c|}{} \\
\hline п/п & г & м & д & ч & мин & $\mathrm{c}$ & $\varphi^{\circ}, \mathrm{N}$ & $\lambda^{\circ}, \mathrm{E}$ & км & M/MLH & Kр \\
\hline 12156 & 2015 & 4 & 7 & 3 & 28 & 21 & 54.81 & 124.83 & 10 & 4.0 & 11.2 \\
\hline 12166 & 2015 & 4 & 12 & 3 & 0 & 7.216 & 54.03 & 134.11 & 10 & 3.3 & 9.9 \\
\hline 12169 & 2015 & 4 & 16 & 23 & 31 & 54.5 & 54.25 & 127.39 & 12 & 4.3 & 11.7 \\
\hline 12213 & 2015 & 6 & 28 & 11 & 41 & 34.43 & 47.58 & 130.73 & 7 & 3.3 & 10.0 \\
\hline 12214 & 2015 & 6 & 29 & 7 & 46 & 13.15 & 51.78 & 132.91 & 13 & 3.5 & 10.3 \\
\hline 12220 & 2015 & 7 & 9 & 1 & 12 & 47.52 & 54.11 & 123.71 & 12 & 4.0 & 11.2 \\
\hline 12233 & 2015 & 7 & 24 & 6 & 25 & 15.14 & 53.96 & 128.04 & 9 & 3.8 & 11.1 \\
\hline 12264 & 2015 & 8 & 31 & 1 & 53 & 27.55 & 42.21 & 135.64 & 367 & 4.2 & \\
\hline 12299 & 2015 & 10 & 27 & 3 & 25 & 12 & 55.72 & 139.82 & 23 & 4.1 & 11.3 \\
\hline 12306 & 2015 & 11 & 12 & 0 & 18 & 41.52 & 45.17 & 130.99 & 8 & 3.5 & 10.2 \\
\hline 12309 & 2015 & 11 & 14 & 14 & 34 & 40.5 & 46.32 & 136.16 & 437 & 3.7 & \\
\hline
\end{tabular}


Приложение 2. Каталог механизмов очагов землетрясений региона Приамурье и Приморье 1964-2014 гг.

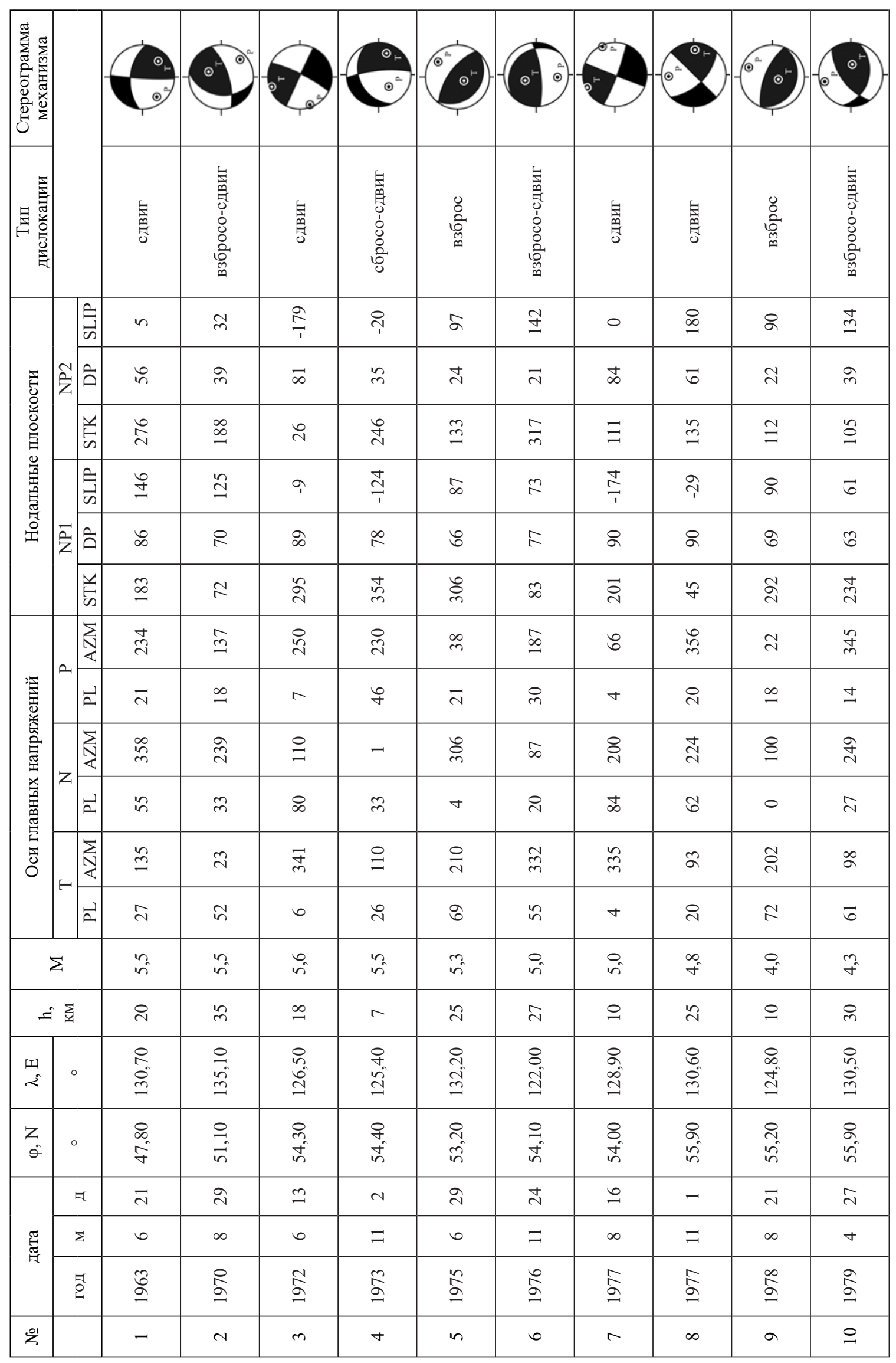


Приложение 2. Каталог механизмов очагов землетрясений региона Приамурье и Приморье 1964-2014 гг.

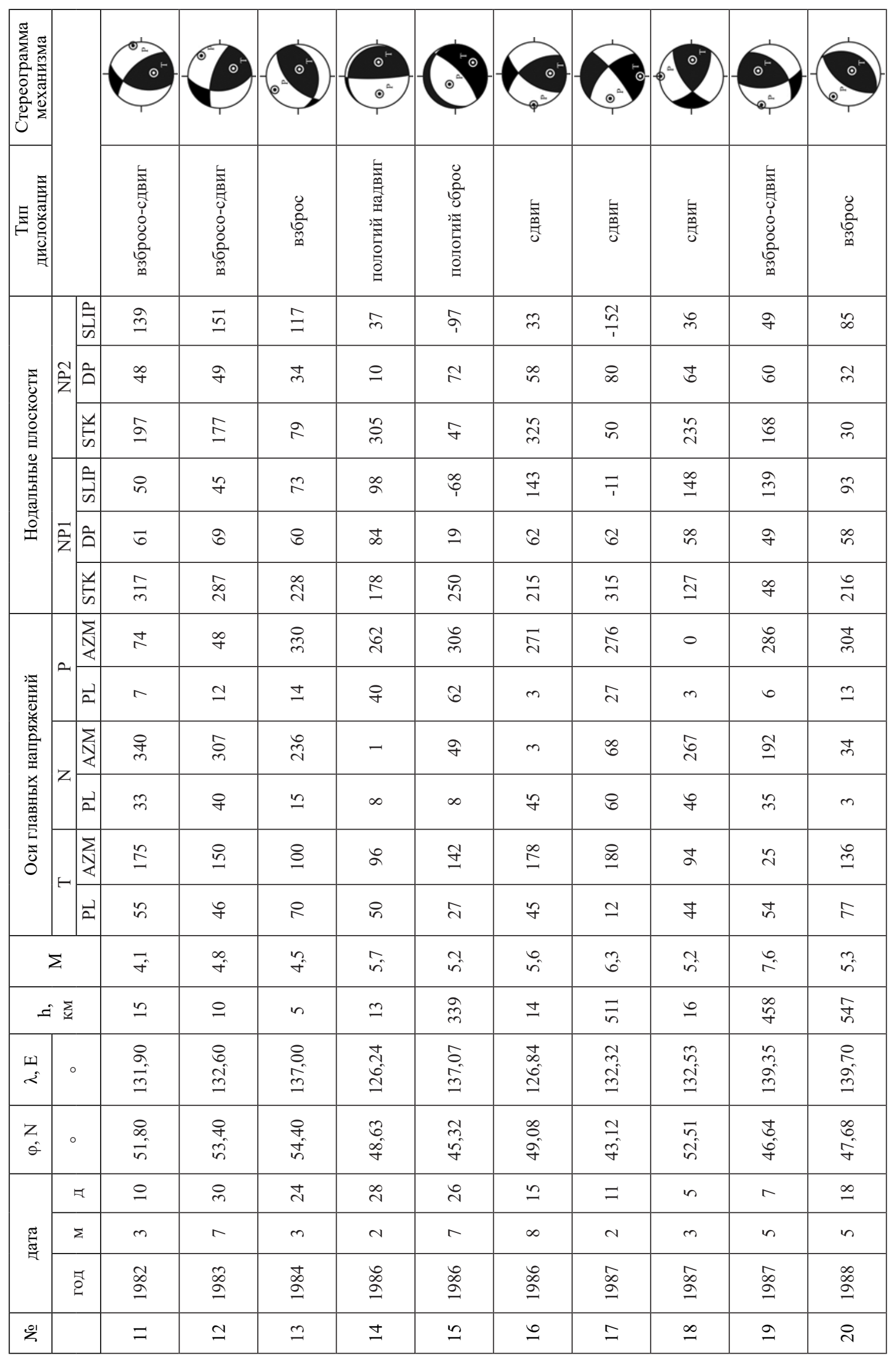


Приложение 2. Каталог механизмов очагов землетрясений региона Приамурье и Приморье 1964-2014 гг.

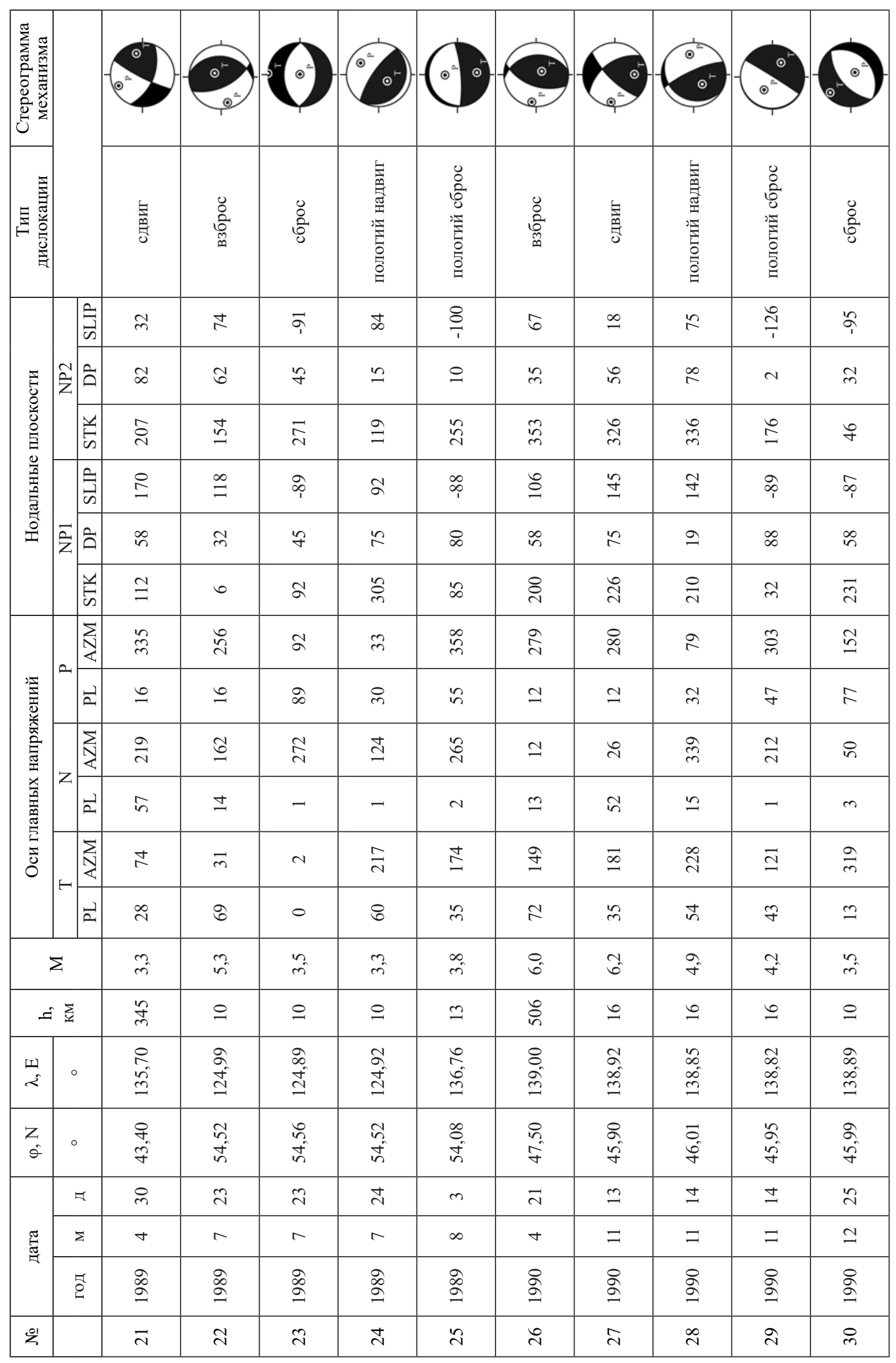




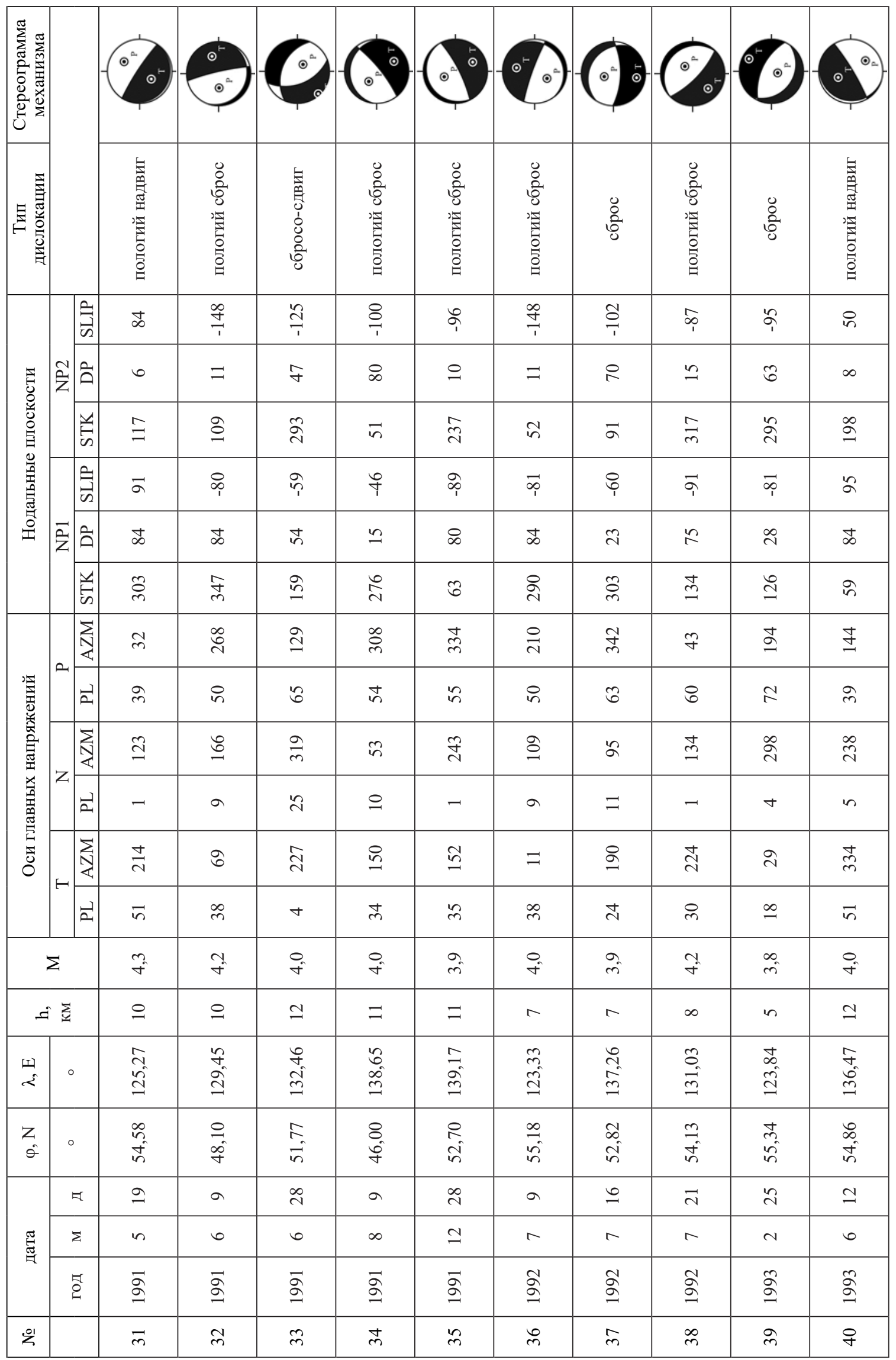


Приложение 2. Каталог механизмов очагов землетрясений региона Приамурье и Приморье 1964-2014 гг.

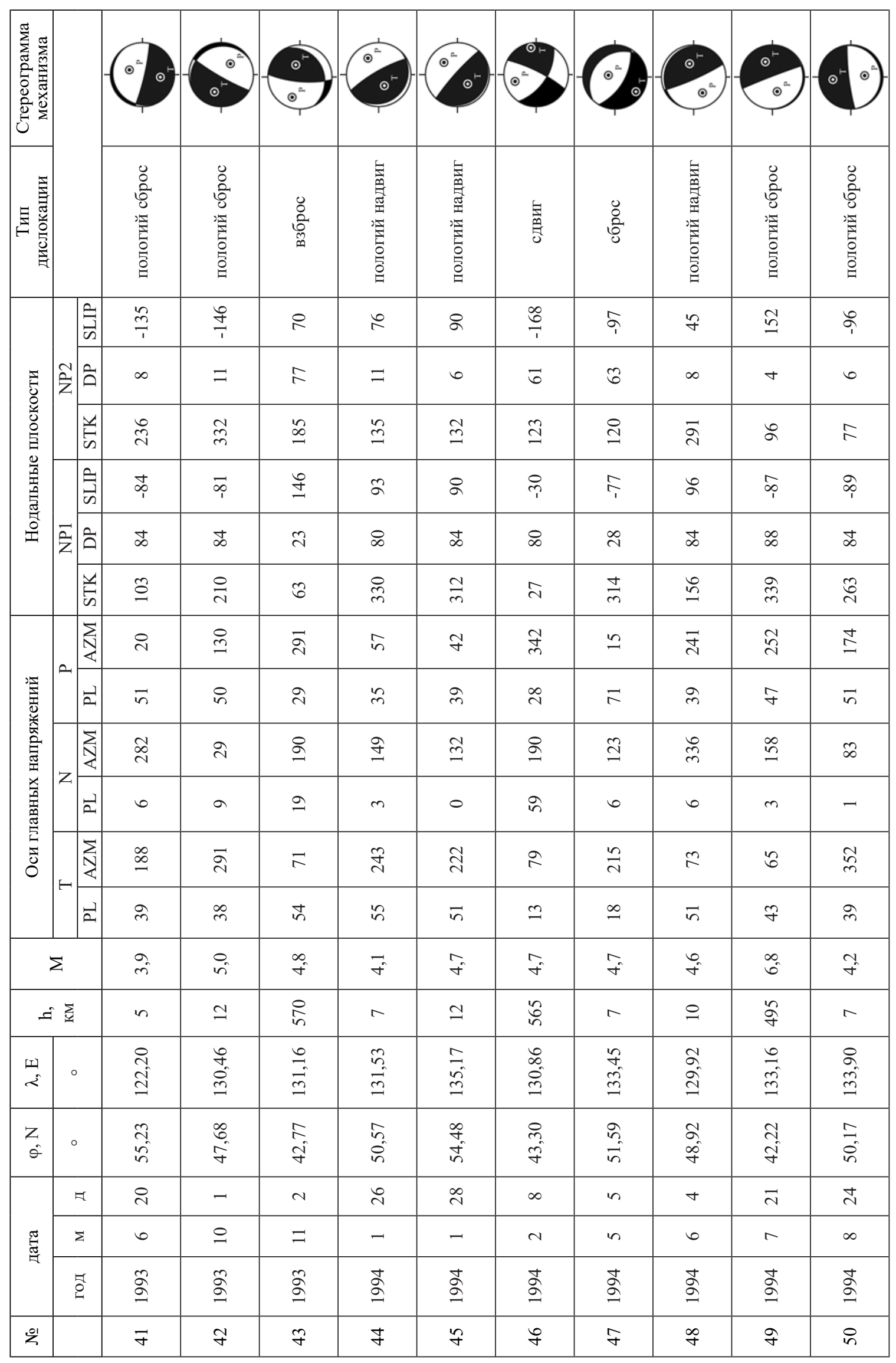




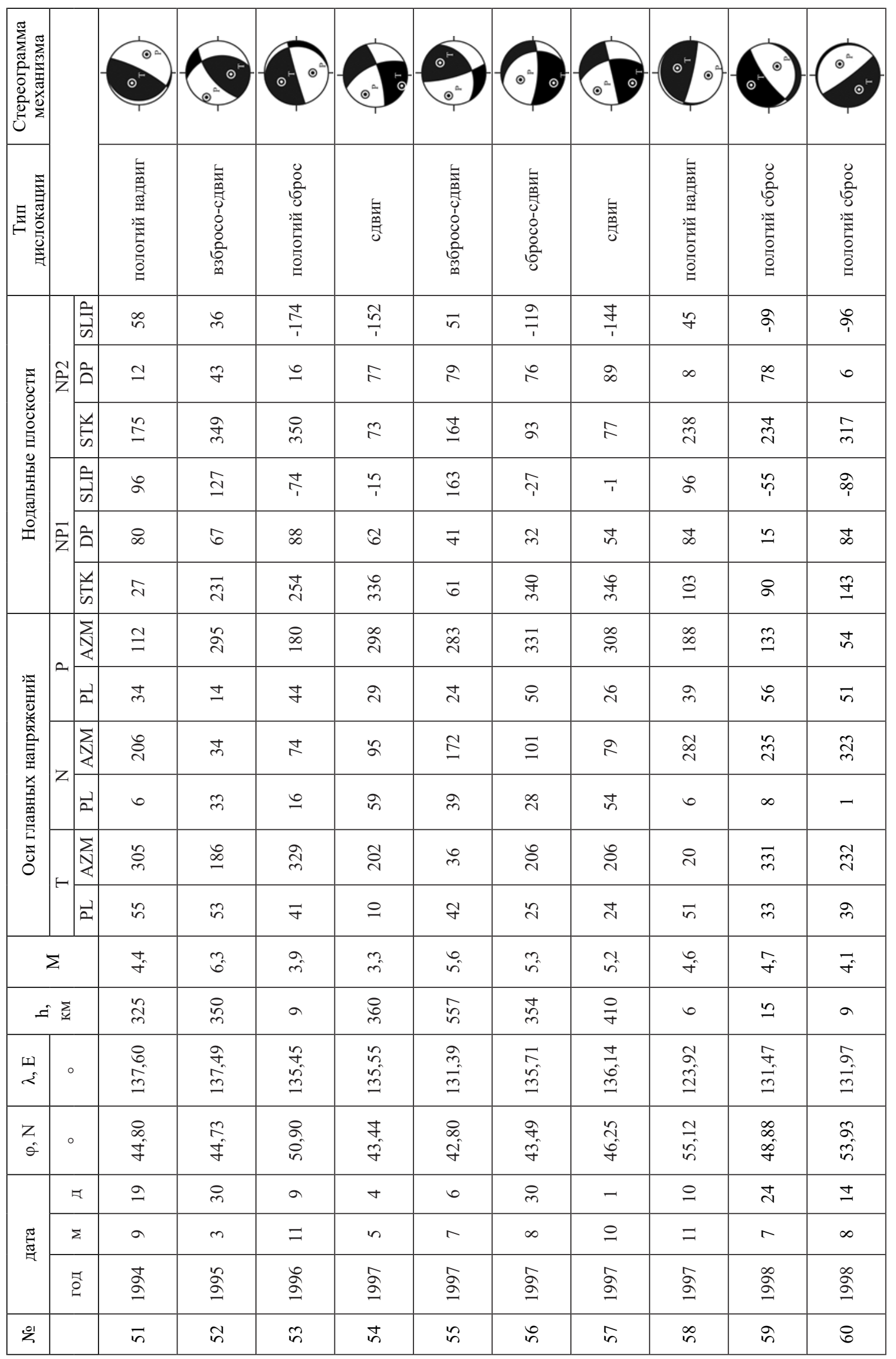


Приложение 2. Каталог механизмов очагов землетрясений региона Приамурье и Приморье 1964-2014 гг.

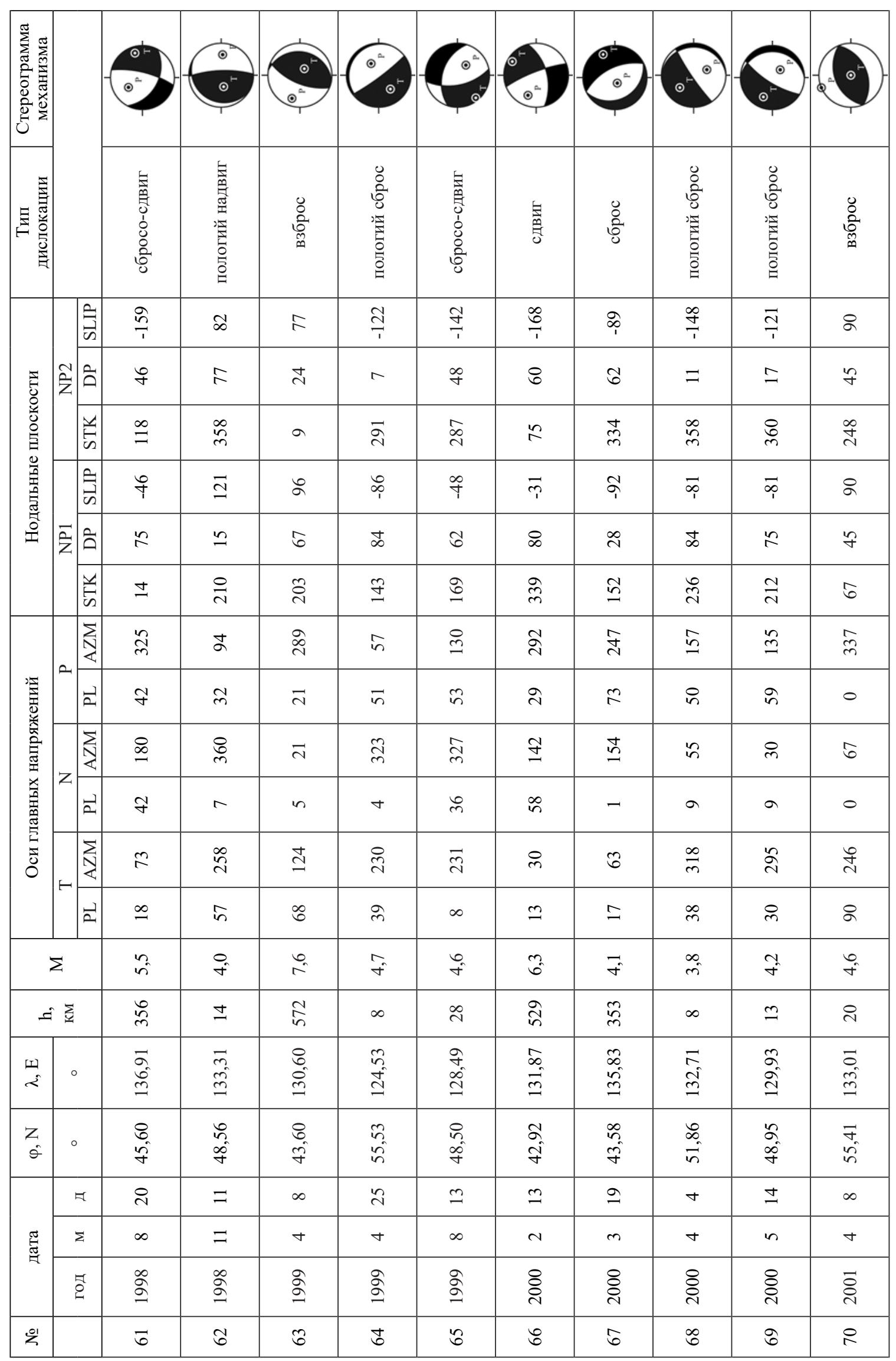




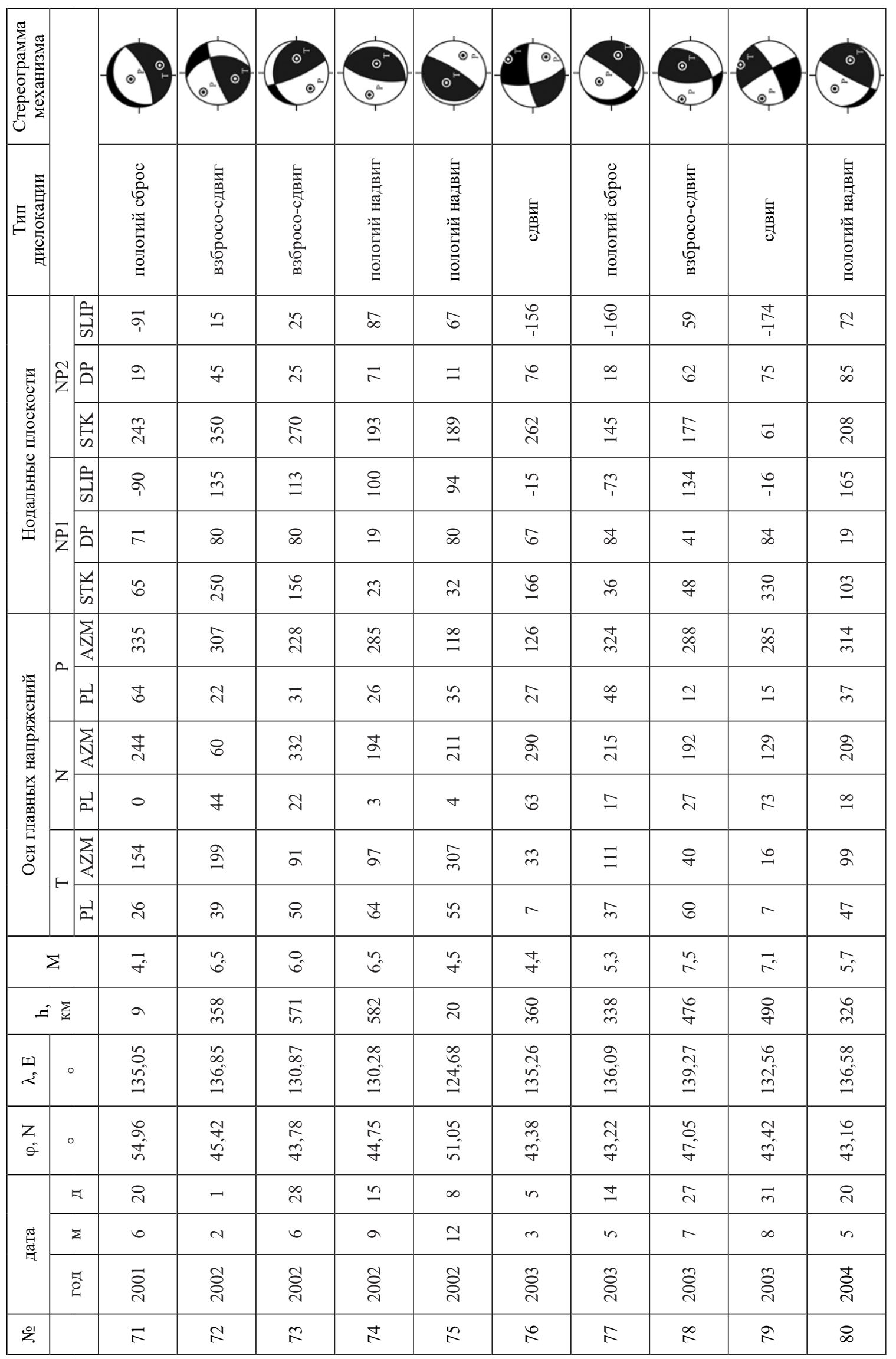


Приложение 2. Каталог механизмов очагов землетрясений региона Приамурье и Приморье 1964-2014 гг.

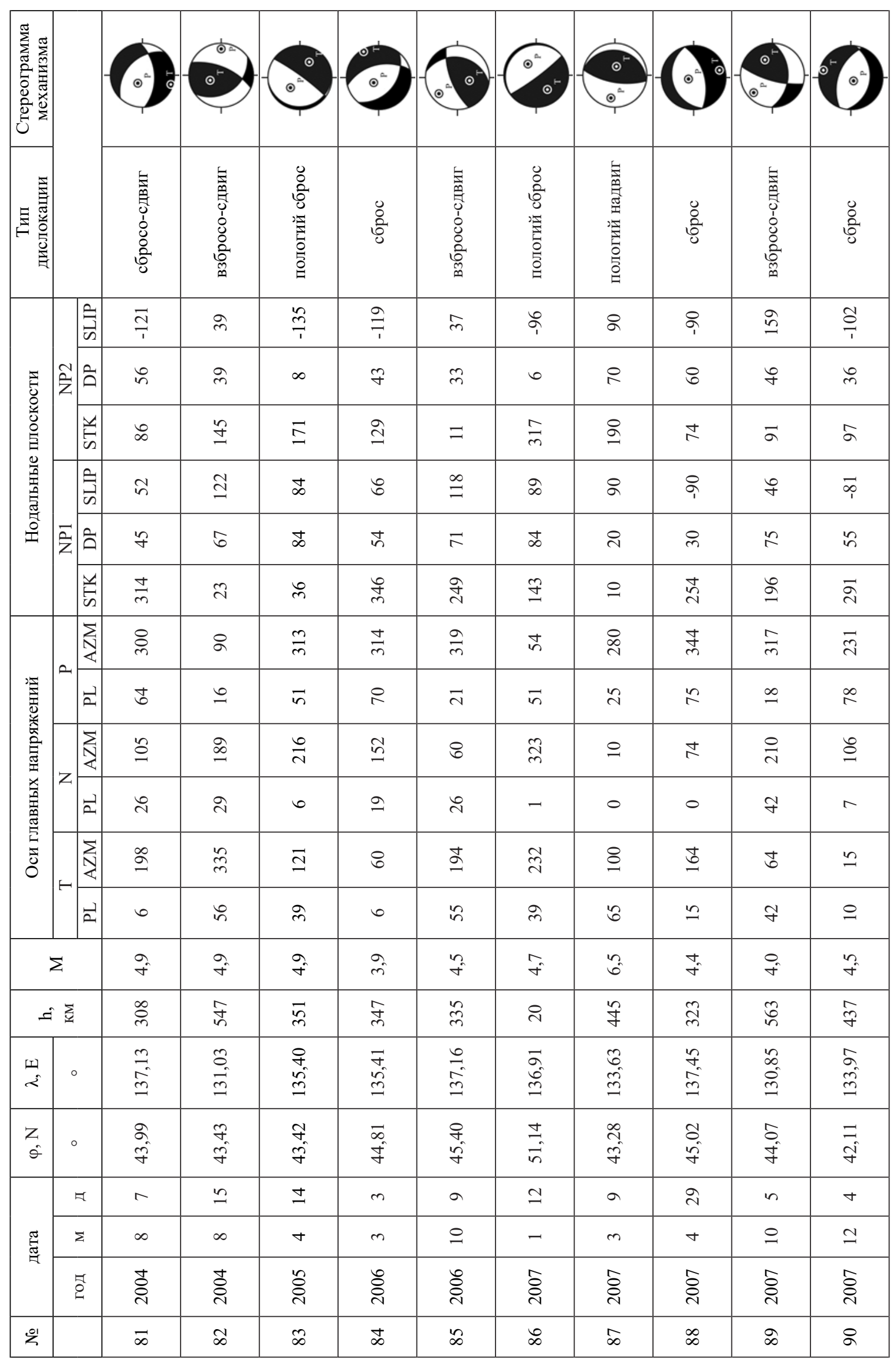


Приложение 2. Каталог механизмов очагов землетрясений региона Приамурье и Приморье 1964-2014 гг.

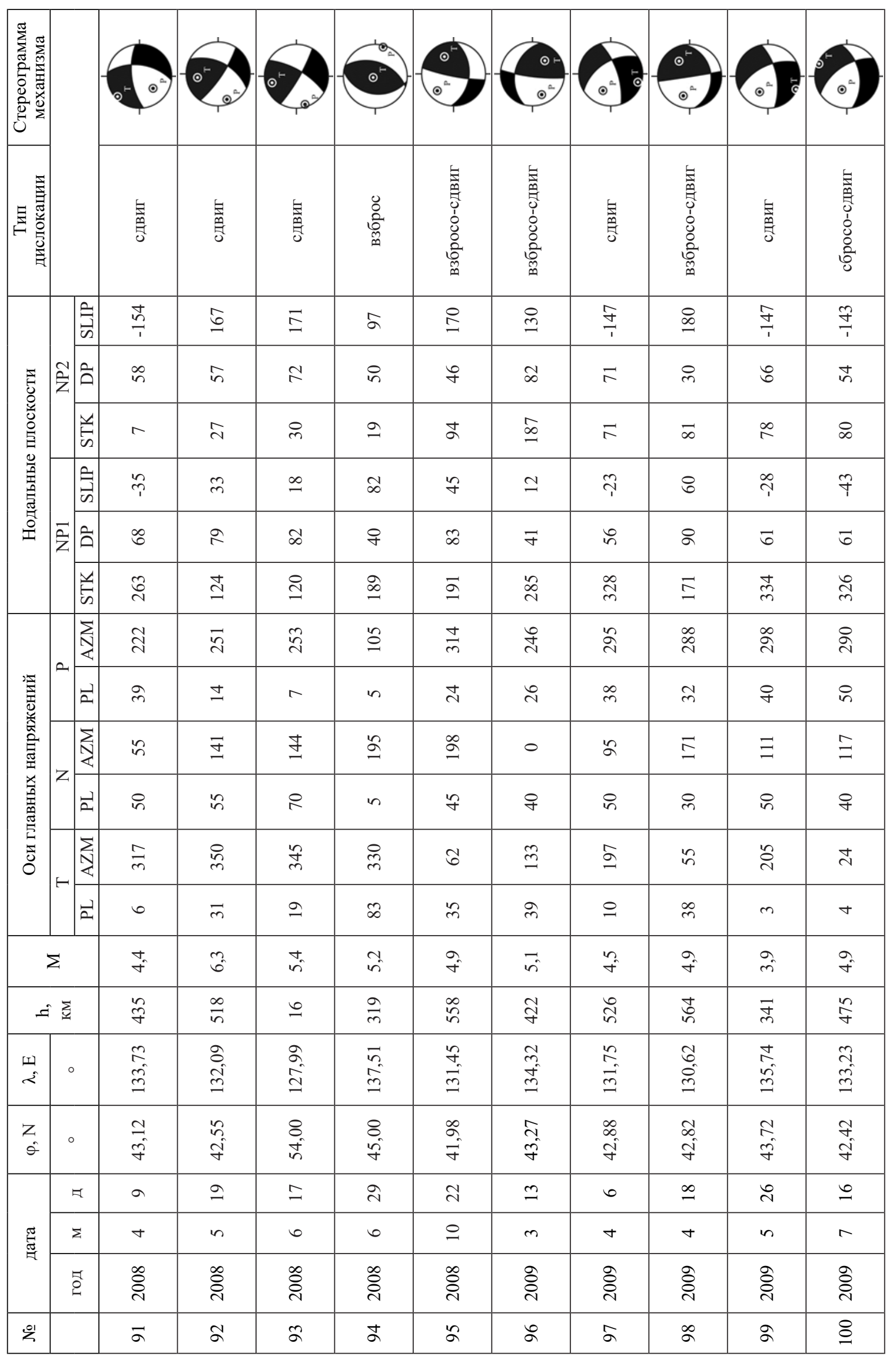


Приложение 2. Каталог механизмов очагов землетрясений региона Приамурье и Приморье 1964-2014 гг.

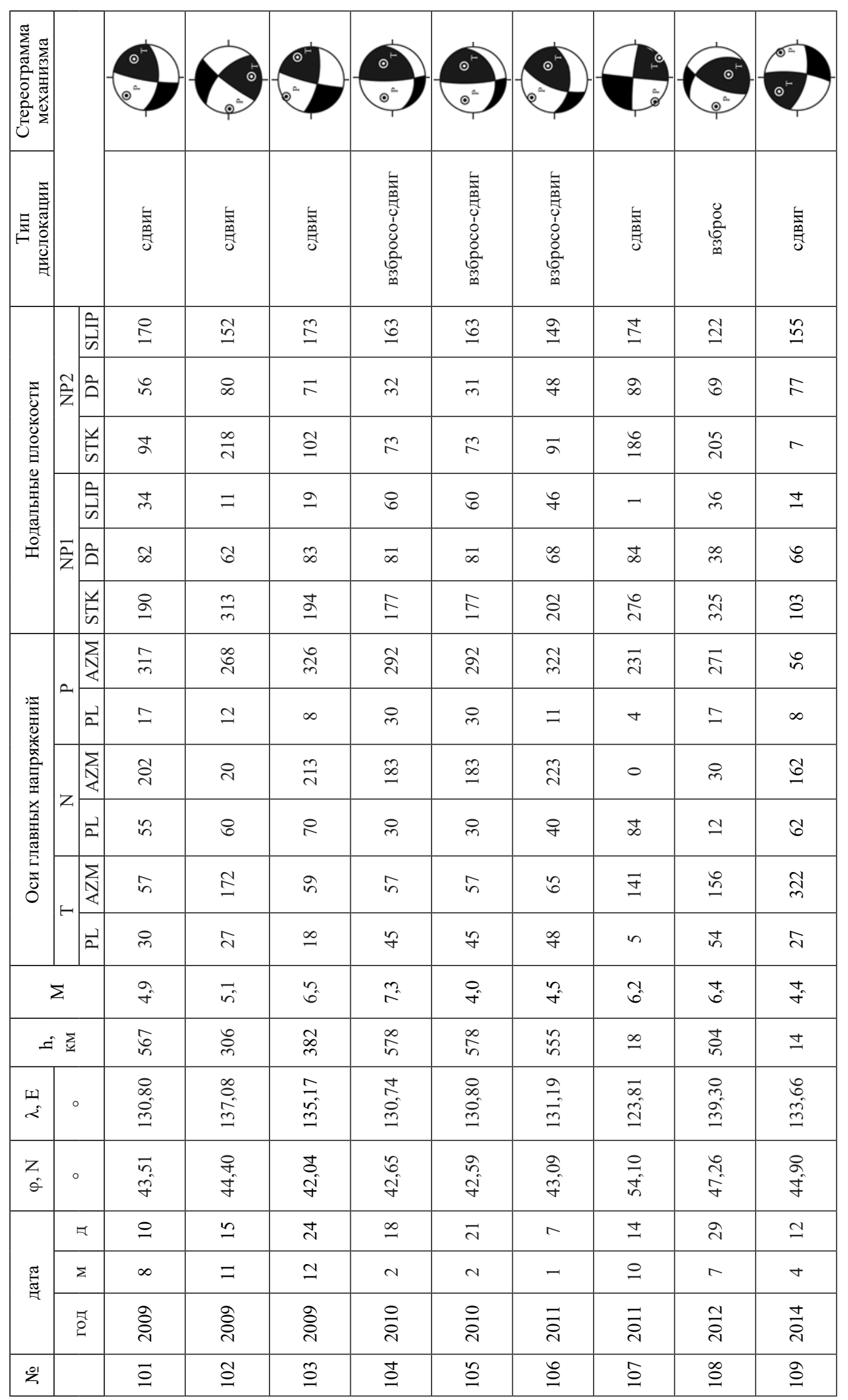


Научное издание

Дмитрий Александрович Сафонов

Татьяна Васильевна Нагорных

Наталья Семеновна Коваленко

\section{СЕЙСМИЧНОСТЬ РЕГИОНА ПРИАМУРЬЕ И ПРИМОРЬЕ}

Электронная верстка, дизайн обложки А.В. Леоненкова

Редактор А.С. Прытков

Корректор И.П. Кремнева Печать цифровая. 